\title{
Mast cell activation and mediator release : implications for the cardiovascular system
}

Citation for published version (APA):

Haaster, C. M. C. J. (1996). Mast cell activation and mediator release : implications for the cardiovascular system. [Doctoral Thesis, Maastricht University]. Universitaire Pers Maastricht. https://doi.org/10.26481/dis.19960229ch

Document status and date:

Published: 01/01/1996

DOI:

10.26481/dis.19960229ch

Document Version:

Publisher's PDF, also known as Version of record

\section{Please check the document version of this publication:}

- A submitted manuscript is the version of the article upon submission and before peer-review. There can be important differences between the submitted version and the official published version of record.

People interested in the research are advised to contact the author for the final version of the publication, or visit the DOI to the publisher's website.

- The final author version and the galley proof are versions of the publication after peer review.

- The final published version features the final layout of the paper including the volume, issue and page numbers.

Link to publication

\footnotetext{
General rights rights.

- You may freely distribute the URL identifying the publication in the public portal. please follow below link for the End User Agreement:

www.umlib.nl/taverne-license

Take down policy

If you believe that this document breaches copyright please contact us at:

repository@maastrichtuniversity.nl

providing details and we will investigate your claim.
}

Copyright and moral rights for the publications made accessible in the public portal are retained by the authors and/or other copyright owners and it is a condition of accessing publications that users recognise and abide by the legal requirements associated with these

- Users may download and print one copy of any publication from the public portal for the purpose of private study or research.

- You may not further distribute the material or use it for any profit-making activity or commercial gain

If the publication is distributed under the terms of Article $25 \mathrm{fa}$ of the Dutch Copyright Act, indicated by the "Taverne" license above, 
MAST CELL ACTIVATION AND MEDIATOR

RELEASE: IMPLICATIONS FOR THE

CARDIOVASCULAR SYSTEM 
Haaster, Charles Marie Catharine Joseph van

Mast cell activation and mediator release: implications for the cardiovascular system / Charles Marie Catharine Joseph van Haaster. -[S.I. : s.n.]. - III.

Proefschrift Rijksuniversiteit Limburg, Maastricht. - Met lit.

opg. - Met samenvatting in het Nederlands.

ISBN 90-9009112-2

Trefw.: mestcellen / hart en bloedvaten

Druk: Datawyse I Universitaire Pers Maastricht

De uitgave van dit proefschrift werd mede mogelijk gemaakt door financiële steun van:

De Nederlandse Hartstichting

Stichting Dr. Ir. J.H.J. van de Laar

Cover: Microscopic photograph of a section of rat heart. Stainings were performed by Marcha Raayman-Geutjes from the Department of Pathology. 


\title{
MAST CELL ACTIVATION AND MEDIATOR RELEASE: IMPLICATIONS FOR THE CARDIOVASCULAR SYSTEM
}

\author{
PROEFSCHRIFT
}

\author{
ter verkrijging van de graad van doctor \\ aan de Rijksuniversiteit Limburg te Maastricht, \\ op gezag van de Rector Magnificus, Prof. mr. M.J. Cohen, \\ ingevolge het besluit van het College van Dekanen
}

in het openbaar te verdedigen op donderdag 29 februari 1996 om 16.00 uur

door

Charles Marie Catharine Joseph van Haaster geboren te Maastricht op 13 juli 1967 


\section{Promotores:}

Prof. dr. G.J. Van der Vusse

Prof. dr. G. Hornstra

\section{Co-promotor:}

Dr. W. Engels

\section{Beoordelingscommissie:}

Prof. dr. ir. W.H.M. Saris (voorzitter)

Prof. dr. M. Borgers

Dr. J.W.M. Heemskerk

Prof. dr. A. van der Laarse (Rijksuniversiteit Leiden)

Prof. dr. R.S. Reneman 
Ik...

Ik ben een piepklein stukje van het wonder...

Maar boven mijn pet gaat zoveel meer dan er onder

(Toon Hermans) 
CHAPTER 1: Introduction and Objectives of the Thesis

CHAPTER 2: $\quad$ A High-Performance Liquid Chromatographic Method for the Determination of Histamine in Biological Samples:

An improved Technique to Isolate Peritoneal Mast Cells

CHAPTER 3: Formation of Prostanoids and Hydroxy Fatty Acids by

Stimulated Rat Peritoneal Mast Cells: Role of the Dietary Fat Type

CHAPTER 4: Histamine Release by Compound 48/80-stimulated Rat Peritoneal Mast Cells: Role of the Dietary Fat Type

CHAPTER 5: Differential Release of Histamine and Prostaglandin $\mathrm{D}_{2}$ in

Rat Peritoneal Mast Cells: Roles of Cytosolic Calcium and Protein Tyrosine Kinases

CHAPTER 6: The Effect of Antigen-induced Mast Cell Degranulation on LDH Release in the Ischemic and Reperfused Rat Heart

CHAPTER 7: Lack of Evidence for a Role of Mast Cell Degranulation in Acute Hypoxia/Reoxygenation-induced Myocardial Injury in the Isolated Rat Heart

CHAPTER 8: Mast Cells and the Induction of Endothelial LeukocyteAdhesion Molecules in Vitro

CHAPTER 9: General Discussion

SUMMARY

SAMENVATTING

PUBLICATIONS

CURRICULUM VITAE

DANKWOORD 


\section{ABBREVIATIONS}

16:0

18:0

$16: 1(n-7)$

$18: 1(n-9)$

$18: 2(n-6)$

$18: 3(n-3)$

$18: 3(n-6)$

$18: 4(n-3)$

20:3(n-6)

20:3(n-9)

$20: 4(n-6)$

20:5(n-3)

22:3(n-9)

$22: 4(n-6)$

22:5(n-6)

22:5(n-3)

22:6(n-3)

AA

$\left[\mathrm{Ca}^{2+}\right]_{\mathrm{i}}$

$\mathrm{BHT}$

CF

CFLC

CK

CMC

$\mathrm{CO}$

CTMC

DAB

DAG

DHA

DHC

DMSO

EC

EPA

ER

$\mathrm{F}_{\mathrm{CE}} \mathrm{RI}$

FCS

G protein

$\mathrm{G}_{\mathrm{i} 3}$

GS

$\mathrm{HCO}$

Hepes

HETE palmitic acid

stearic acid

palmitoleic acid

oleic acid

linoleic acid

$\alpha$-linolenic acid

$\gamma$-linolenic acid

stearidonic acid

dihomo- $\boldsymbol{\gamma}$-linolenic acid

Mead acid

arachidonic acid

timnodonic acid, eicosapentaenoic acid

dihomo-mead acid

adrenic acid

Osmond acid

clupanodonic acid

cervonic acid, docosahexaenoic acid

arachidonic acid

cytosolic free $\mathrm{Ca}^{2+}$ concentration

3,5-di-tert-butyl-4-hydroxytoluene

coronary flow

cardiac fibroblast-like cells

creatine kinase (EC 2.7.3.2)

cardiomyocytes

cyclooxygenase

connective tissue mast cell

diaminobenzidine

diacylglycerol

docosahexaenoic acid, cervonic acid

methyl-2,5-dihydroxycinnamate

dimethyl sulfoxide

endothelial cells

eicosapentaenoic acid, timnodonic acid

endoplasmic reticulum

immunoglobulin E receptor

foetal calf serum

GTP-binding protein

specific GTP-binding protein

genistein

hydrogenated coconut oil

4-(2-hydroxyethyl)-1-piperazineethanesulfonic acid

hydroxyeicosatetraenoic acid 
5-HT

$\mathrm{HHT}$

HODE

HPETE

HPLC

HUVEC

ICAM-1

IgE

IL

Ins $(1,4,5) \mathrm{P}_{3}$

LA

$\mathrm{LDH}$

LPS

$\mathrm{LTC}_{4}$

LVDP

MAPK

MDA

MMC

$\mathrm{MO}$

MUFA

NO

OPA

PAF

PC 19:0

PG

PGDS

$\mathrm{PGI}_{2}$

PKC

$\mathrm{PLA}_{2}$

PLC

$\mathrm{PO}$

PUFA

RHEC

RMCP I

ROC

SAFA

SCF

SO

SRC

$\mathrm{TxB}_{2}$

TyrK

VCAM-1

VLA-4

VIP 5-hydroxytryptamine, serotonin

hydroxyheptadecatrienoic acid

hydroxyoctadecadienoic acid

hydroperoxyeicosatetraenoic acid

high-performance liquid chromatography

human umbilical vein endothelial cell

intercellular adhesion molecule-1

immunoglobulin E

interleukin

inositol $(1,4,5)$ trisphosphate

linoleic acid

lactate dehydrogenase (EC 1.1.1.27)

lipopolysaccharide

leukotriene $\mathrm{C}_{4}$

left ventricular developed pressure

mitogen-activated protein kinase

malondialdehyde

mucosal mast cell

mackerel oil

monounsaturated fatty acids

nitric oxide

o-phtalaldehyde

platelet-activating factor

1,2 dinonadecanoyl-sn-glycero-3-phosphocholine

prostaglandin

$\mathrm{PGD}_{2}$ synthase

prostacyclin

protein kinase $\mathrm{C}$

phospholipase $\mathrm{A}_{2}$

phospholipase C

peroxidase (EC 1.11.1.7)

polyunsaturated fatty acid

rat heart endothelial cell

rat mast cell proteinase I

receptor-operated channel

saturated fatty acids

stem cell factor

sunflowerseed oil

store-regulated channel

thromboxane $B_{2}$

protein tyrosine kinase(s)

vascular cell adhesion molecule-1

very late antigen-4

vasoactive intestinal peptide 


$$
\text { | CHAPTER } 1
$$

Introduction and Objectives of the Thesis 


\subsection{History and Characteristics of Mast Cells}

In his doctoral thesis ${ }^{24}$ (1878), Paul Ehrlich described the presence of cells residing in connective tissue near blood vessels, which contained prominent cytoplasmic granules with a high affinity for certain basic dyes. These cells were considered to be 'overfed' and were, therefore, called 'mast cells', derived from the German word 'Mastung'. Early indications that these cells were involved in hypersensitivity reactions came from Unna ${ }^{99}$, who reported many of these cells in the cutaneous lesions of patients with urticaria pigmentosa. A hypersensitivity reaction was firstly described by Portier et al. ${ }^{80}$ in dogs given sea anemone toxin. Subsequently, it was shown that serum from affected animals could be used to transfer this hypersensitivity reaction to non-affected animals. ${ }^{4}$ In 1921 Prausnitz et al. ${ }^{81}$ demonstrated that serum from a person allergic to horses, when injected into human skin, induced a hypersensitivity reaction when the recipient was challenged with antigen to which the original donor was sensitive. The serum 'reagins' have later been identified as a specific immunoglobulin class termed immunoglobulin E (IgE), the cells in the skin sensitized by IgE were identified as mast cells. Since that time, mast cells have been shown to express specific membrane receptors $\left(F_{C \varepsilon} R I\right)$ that specifically bind the $F_{c}$ portion of IgE antibodies with high affinity. ${ }^{13}$ The cross-linkage of two IgE molecules by allergens triggers the mast cell to undergo an integrated, noncytolytic series of biochemical and ultrastructural alterations, commonly known as exocytosis, resulting in the exposure of the matrices of the cytoplasmic granules to the external environment and release of compounds such as histamine and proteases, stored in the granules. This is associated with de novo synthesis and release of other mediators such as prostaglandins and/or leukotrienes, compounds which are responsible for some of the clinical symptoms associated with immediate hypersensitivity. 30,93

In contrast to their circulating counterpart, the basophil, mast cells are absent in the blood and are ordinarily distributed throughout normal connective tissue and mucosal surfaces. Mast cells are often found in the close vicinity of blood vessels and beneath epithelial surfaces, such as those of the respiratory and gastrointestinal systems and the skin, areas that are frequently exposed to environmental antigens. ${ }^{93}$ Mast cells have also been found in various tissues and organs such as the peritoneum, skin, lung, gut, stomach, thymus, liver and the heart. ${ }^{30,32}$

\subsection{Mast Cell Heterogeneity, Distribution and Origin}

Mast cells from different anatomical locations exhibit readily discernible differences in morphology and granule content. ${ }^{6,25}$ Due to their localization and histochemical staining properties, the cells are subdivided into connective tissue-type mast cells (CTMC), present in skin, peritoneal cavity, heart and at numerous other locations, and mucosal mast cells (MMC), present in large numbers in the mucosa of the midgut and the lung. Basic differences between these two mast cell populations are summarized in Table 1.1 and are discussed below. 
Table 1.1: Major Differences between Mast Cell Types

\begin{tabular}{|c|c|c|}
\hline & Mucosal Mast Cell (MмC) & $\begin{array}{l}\text { Connective Tissue Mast } \\
\text { cell (CTMC) }\end{array}$ \\
\hline location in vivo & gut and lung & $\begin{array}{l}\text { ubiquitous } \\
\text { (peritoneum, skin, heart) }\end{array}$ \\
\hline size & 8-15 $\mu \mathrm{m}$ & $9-20 \mu \mathrm{m}$ \\
\hline nucleus & unilobular or bilobular & unilobular \\
\hline granules & small and few & large and many \\
\hline life span & $<40$ days & $>40$ days \\
\hline major $\mathrm{AA}$ metabolite & $\mathrm{LTC}_{4}$ & $\mathrm{PGD}_{2}$ \\
\hline ratio $\mathrm{LTC}_{4} / \mathrm{PGD}_{2}$ & $25: 1$ & $1: 40$ \\
\hline histamine/serotonin content & + & ++ \\
\hline toluidine blue staining at neutral $\mathrm{pH}$ & - & + \\
\hline major proteoglycan & chondroitin sulphate $\mathrm{E}$ & heparin \\
\hline T-cell dependent proliferation & + & $\cdot$ \\
\hline mediators important in proliferation & interleukins & stem cell factor \\
\hline
\end{tabular}

Adapted and modified from Roitt $^{85}$

The mature CTMC is a relatively large cell with a single, small ovoid nucleus and a cytoplasm packed with numerous, uniformly dense, membrane-bound granules (Fig. 1.1). ${ }^{23}$ These cells are relatively long-lived ( $>40$ days) and contain the usual array of subcellular organelles, including mitochondria, ribosome-bound endoplasmic reticulum, a Golgi complex and abundant submembranous filaments. CTMC may contain up to 1000 small secretory granules ( 0.2 to $0.4 \mu \mathrm{m}$ in diameter), which occupy about $50-55 \%$ of the total cytoplasmic volume. In contrast, MMC are somewhat smaller than their connective tissue counterparts and their granules are fewer in number. MMC have a lower histamine and serotonin content than CTMC, which is most probably due to a reduced number of granules. ${ }^{25}$ Major arachidonic acid (AA) metabolites (prostaglandins and leukotrienes) are produced by both mast cell types, but in different amounts. For example, the ratios of production of leukotriene $\mathrm{C}_{4}\left(\mathrm{LTC}_{4}\right)$ to prostaglandin $\mathrm{D}_{2}\left(\mathrm{PGD}_{2}\right)$ is $25: 1$ in the MMC and 1:40 in the CTMC, respectively. ${ }^{86}$

CTMC are often indicated as 'typical' mast cells since they stain easily with various metachromatic dyes. For instance, CTMC usually stain with toluidine blue at neutral $\mathrm{pH}$, whereas MMC stain poorly under these conditions and require acidic conditions to become stained. ${ }^{5}$ The good staining properties at neutral $\mathrm{pH}$ of CTMC probably results from the presence of large amounts of heparin within these cells. ${ }^{12} \mathrm{MMC}$ contain little or no heparin and, instead, comprise an oversulfated chondroitin, named chondroitin sulphate $\mathrm{E}^{83}$ Although both CTMC and MMC respond to immunological activation and to the calcium ionophore $\mathrm{A} 23187$, they differ in their response to various other agonists (Fig. 1.1). Thus, MMC, in contrast to CTMC, are totally unresponsive to the 'classical' mast cell-degranulating agent compound $48 / 80$, somatostatin, bradykinin and also to the vasoactive intestinal peptide (VIP). 


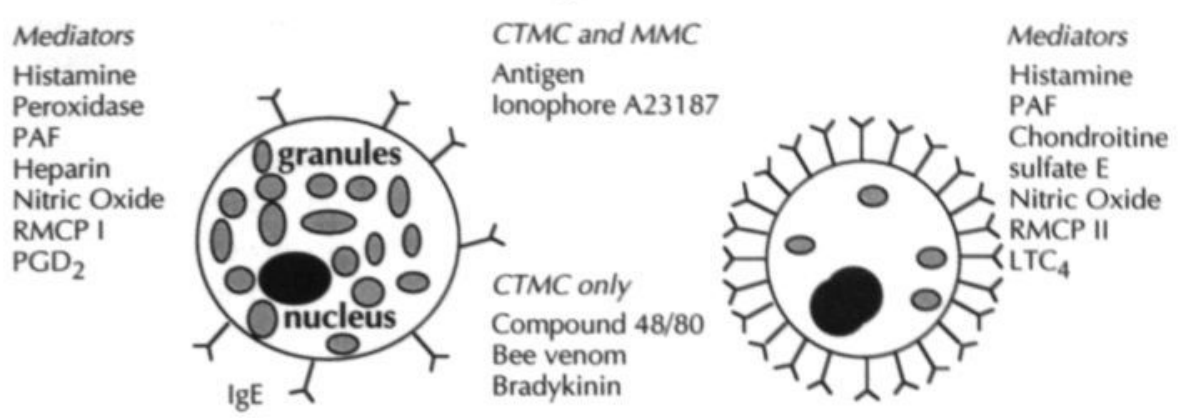

Figure 1.1: Mediators and agonists in different types of mast cells

Mast cells are progenies of multipotential hematopoietic stem cells. ${ }^{52,74}$ Most other progenies of these multipotential stem cells, such as erythrocytes, neutrophils and basophils, leave the bone marrow after they have differentiated. However, mast cells do not complete their differentiation in the hematopoietic tissue. Morphologically unidentified precursors leave the bone marrow, enter the blood and subsequently migrate into connective or mucosal tissue, where they proliferate and differentiate into morphologically identifiable CTMC or MMC due to various factors present in the microenvironment. ${ }^{51}$ Mast cell proliferation/differentiation has been shown to be mediated by $\mathrm{T}$ cell-dependent and fibroblast-dependent mechanisms. ${ }^{3} \mathrm{~T}$ celldependent mechanisms are predominantly responsible for the proliferation/ differentiation of MMC from mast cell progenitors, a process which is stimulated by interleukins (IL) such as IL-3, IL-4, IL-9 or IL-10. $35,46,58,96$ In contrast, the proliferation/ differentiation of mast cell progenitors to mature CTMC is largely dependent on stem cell factor (SCF), produced by fibroblasts. ${ }^{97}$

\subsection{Mediators Released from Activated Mast Cells}

Mast cell granules contain a variety of mediators which are rapidly released upon activation. In addition, mast cells release a variety of newly formed mediators, such as eicosanoids, hydroxy fatty acids and leukotrienes. Various mast cell-derived mediators and their biological functions are summarized in Table 1.2. For the sake of clarity, only some aspects of mediators relevant to the thesis will be discussed.

\subsubsection{Histamine}

Histamine is the best-known mediator released from mast cells. In peritoneal mast cells, which belong to the connective tissue-type, histamine is present in high amounts and constitutes about $10 \%$ of the dry weight of these cells. ${ }^{56}$ In tissues, histamine is predominantly stored in secretory granules of mast cells, where it binds by electrostatic interactions with the carboxyl groups of heparin. ${ }^{84}$ 
CHAPTER 1

Table 1.2: Various Mast Cell-derived Mediators and their Biological Functions

\begin{tabular}{|c|c|c|}
\hline Mediator & $\begin{array}{l}\text { Action } \\
\text { Mediators in secretory granules }\end{array}$ & References \\
\hline $\begin{array}{l}\text { Chymase/ } \\
\text { Proteinase }\end{array}$ & $\begin{array}{l}\text { mucus secretion ' } \\
\text { smooth muscle contraction, } \\
\text { degradation of neuropeptides }\end{array}$ & 20,78 \\
\hline Histamine & $\begin{array}{l}\text { vasodilation } \\
\text { positive chronotropic/inotropic effects on the heart } \\
\text { bronchoconstriction } \\
\text { endothelial cell permeability, } \\
\text { endothelial cell proliferation, } \\
\text { gastric acid secretion, }\end{array}$ & 41,76 \\
\hline 5-HT & $\begin{array}{l}\text { vasodilation } \\
\text { vascular permeability } \\
\text { Newly formed mediators }\end{array}$ & 28 \\
\hline $\mathrm{LTC}_{4}$ & $\begin{array}{l}\text { vasoconstriction } \\
\text { mucus secretion ' } \\
\text { smooth muscle contraction ' }\end{array}$ & 78,102 \\
\hline LTB $_{4}$ & $\begin{array}{l}\text { vascular permeability, } \\
\text { neutrophil/eosinophil activation }\end{array}$ & 14 \\
\hline NO & $\begin{array}{l}\text { vasodilation } \\
\text { platelet aggregation }\end{array}$ & 91 \\
\hline PAF & $\begin{array}{l}\text { vascular permeability } \\
\text { leukocyte activation }\end{array}$ & 15,42 \\
\hline $\mathrm{PGD}_{2}$ & $\begin{array}{l}\text { modification of local neurotransmission } \\
\text { histamine-induced increase of } \\
\text { capillary permeability } \\
\text { vasodilation }\end{array}$ & 69,98 \\
\hline TNF $\alpha$ & $\begin{array}{l}\text { vasoconstriction } \\
\text { neutrophil/eosinophil activation } \\
\text { bronchoconstriction }\end{array}$ & $7,65,104$ \\
\hline
\end{tabular}

The biological effects of histamine in various cells (see below) are mediated through distinct receptors of at least three subtypes $\left(\mathrm{H}_{1}, \mathrm{H}_{2}\right.$ and $\left.\mathrm{H}_{3}\right)$. The signal transduction mechanisms by which histamine exerts its effects are different in each subtype. For instance, $\mathrm{H}_{1}$-receptors are coupled to phosphoinositide-breakdown and $\mathrm{Ca}^{2+}$ mobilization, while $\mathrm{H}_{2}$-receptors are linked to adenylate cyclase. ${ }^{77}$ The precise mechanism involved in stimulus-response coupling following $\mathrm{H}_{3}$-receptor activation has not yet definitively been clarified. Responses mediated through $\mathrm{H}_{1}$-receptors are antagonized by antihistamines such as mepyramine, whereas those responses mediated 
through $\mathrm{H}_{2}$-receptors and $\mathrm{H}_{3}$-receptors are antagonized by compounds such as cimetidine and thioperamide, respectively, ${ }^{41,77}$ Histamine evokes a wide range of biological effects which are similar for many animal species. However, large differences in sensitivity to this amine are observed between various species. For instance, in the rat, relatively high concentrations of histamine are required to evoke a vasodilatory effect, primarily mediated by $\mathrm{H}_{1}$-receptors, whereas the guinea pig vasculature already responds to much lower histamine concentrations. Together with other factors released from activated mast cells, such as serine proteinases, lysosomal enzymes and tumor necrosis factor ( $\mathrm{TNF} \alpha$ ), histamine contributes to the pathogenesis of inflammatory reactions, for instance by increasing vascular permeability. ${ }^{64}$ Histamine has also been shown to be involved in gastric acid secretion, a process which is potently inhibited by histamine $\mathrm{H}_{2}$-receptor antagonists. ${ }^{11}$ In the lungs, histamine causes bronchoconstriction and therefore this compound plays an important role in asthma. Histamine has also been shown to enhance vascularization and endothelial cell proliferation, which implies the involvement of mast cells in the process of wound healing and tissue remodeling. ${ }^{29,76}$ Finally, histamine has positive inotropic as well as chronotropic effects on the heart and, induces a variety of arrhythmogenic responses in various species. ${ }^{63}$

\subsubsection{Membrane Fatty acid Composition and Release of Prostanoids: Role of the Diet}

The fatty acid composition of membranes is a result of cellular de novo fatty acid synthesis and incorporation of fatty acids derived from the diet. ${ }^{44}$ De novo synthesis of long-chain (poly-)unsaturated fatty acids starts from two precursor fatty acids, palmitic acid (16:0) and stearic acid (18:0), which may endogenously be formed by elongation of acetyl CoA (Fig. 1.2). Since palmitic acid and stearic acid need not necessarily be provided by the diet, these fatty acids are 'non-essential'. Both fatty acids are substrates for $\Delta 9$ desaturase, which introduces a double bond between the 9 th and 10 th carbonatom (counted from the carboxyl group) into saturated fatty acids. $\Delta 9$ Desaturation of $16: 0$ results in the formation of $16: 1(n-7)$, whereas similar action on 18:0 results in the formation of $18: 1(n-9)$. In this notation, ' 18 ' denotes the total number of carbon-atoms, ' 1 ' the number of double bonds and ' $(n-7)$ ' the position of the first carbon-atom involved in a double bond (counted from the terminal methyl group). Subsequent chain-elongation and $\Delta 6$ and/or $\Delta 5$ desaturation result in the formation of a variety of long-chain monounsaturated and polyunsaturated fatty acids of the (n-7) or (n-9) family, respectively. Since vertebrate cells lack $\Delta 12$ and $\Delta 15$ desaturases, they cannot de novo synthetize linoleic acid, 18:2(n-6), and $\alpha$-linolenic acid, 18:3(n-3), the 'parent' fatty acids of the $(n-6)$ and $(n-3)$ family, respectively. These fatty acids, therefore, must be provided by the diet and are called 'essential fatty acids'. After $\Delta 6$ desaturation (Fig 1.2), subsequent chain-elongation and $\Delta 5$-desaturation, linoleic acid, 18:2(n-6), is converted into arachidonic acid, 20:4(n-6), the predominant substrate for the eicosanoid synthetizing pathway (see below). Similar actions on $\alpha$-linolenic acid, 18:3(n-3), results in the formation of timnodonic acid, 20:5(n-3). Fatty acids of the (n-3) and (n-6) family are known to compete with each other for desaturation by desaturase enzyme 
systems. ${ }^{44}$ in general, the affinity of substrate fatty acids for desaturation by a desaturase system increases with the number of double bonds. For instance, desaturation of linoleic acid by $\Delta 6$ desaturase is inhibited by $\alpha$-linolenic acid and other long-chain polyunsaturated fatty acids. ${ }^{16}$

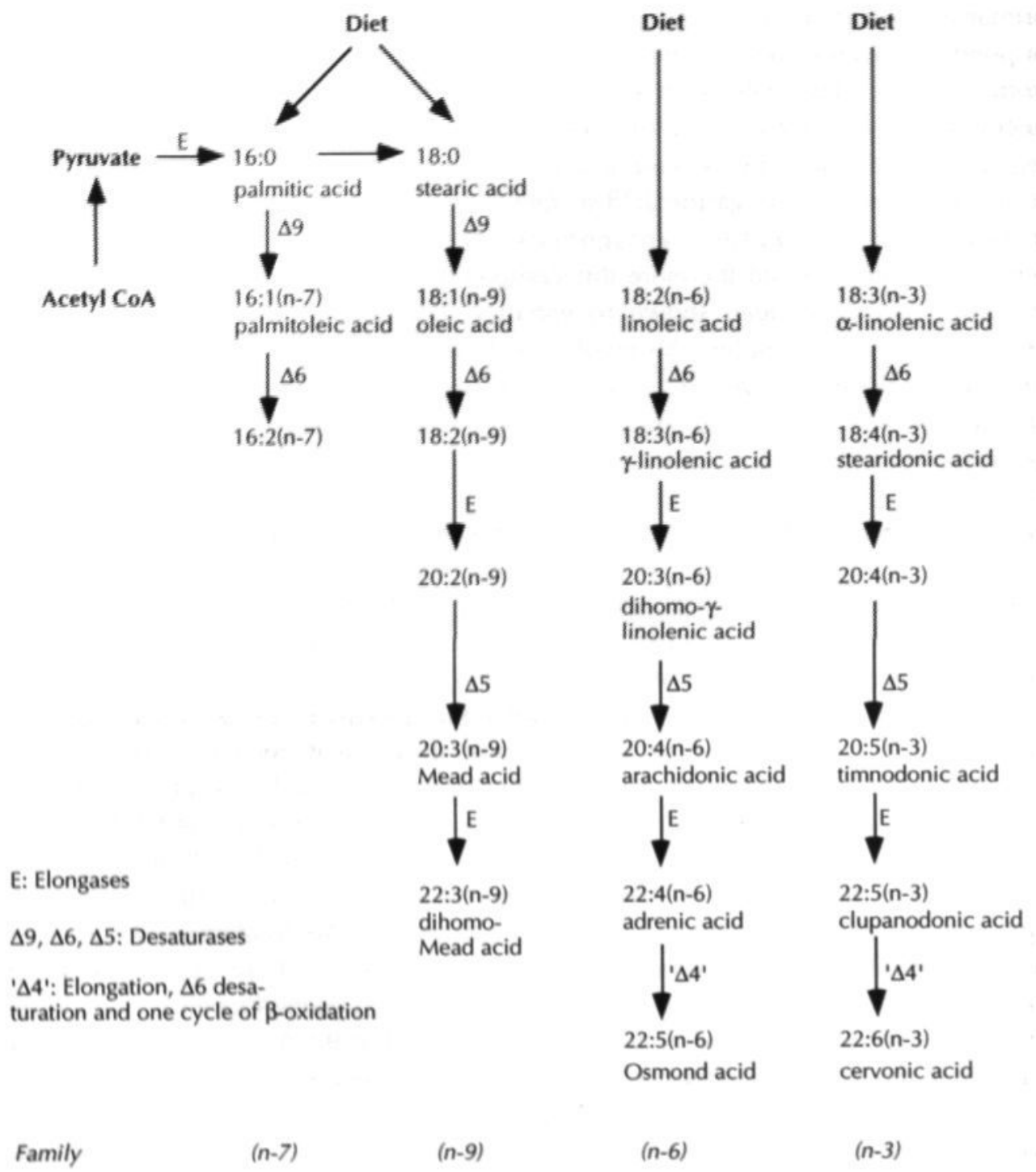

Figure 1.2: Major biosynthetic pathways of fatty acids

In plasma, fatty acids are transported by lipoproteins in the form of triacylglycerols or complexed to albumin. These fatty acids are liberated from triacylglycerols by the action of specific enzymes, such as lipoprotein lipases. ${ }^{34}$ After transport through endothelial cells, fatty acids are presented to resident tissue mast cells. Once entered into these 
cells, fatty acids are transported to the mitochondria where they are oxidized in peroxisomes or are stored in a triacylglycerol pool. In addition, fatty acids may be metabolized by intracellular enzyme systems or are incorporated in membrane phospholipids. When incorporated in phospholipids, polyunsaturated fatty acids are not only important constituents of cellular membranes, but, after liberation by the action of phospholipase $A_{2}$, they may also serve as precursor ('parent') fatty acids for the formation of prostanoids, hydroxy fatty acids and leukotrienes. Prostanoids comprise two different groups of compounds: prostaglandins and thromboxanes. All prostanoids contain 20 carbon-atoms arranged in a cyclic structure carrying two side-chains, one of which is terminated by a carboxyl group and the other by a methyl group. Depending on the configuration of the cyclic part of the molecule, prostanoids are divided into various 'families', indicated by the capitals A to I. Each prostanoid family consists of 1, 2 and 3series, depending on the number of double bonds in their two side chains. Prostanoids from the 1 and 2-series are derived from dihomo- $\gamma$-linolenic acid, 20:3(n-6), and arachidonic acid, 20:4(n-6), respectively, whereas timnodonic acid, 20:5(n-3), is the substrate for the 3 -series of prostanoids. In most animal cells, the arachidonic acid content is much higher than that of dihomo- $\gamma$-linolenic and timnodonic acid. In addition, timnodonic acid is a poor substrate for the cyclooxygenase system ${ }^{75}$ (see below). As a consequence, prostaglandins from the 2-series are most abundantly produced.

Once released from the endogenous phospholipid pool by the action of phospholipase $A_{2}$, arachidonic acid may immediately be oxidized by various enzyme systems, such as cyclooxygenase, which converts this fatty acid to the endoperoxide $\mathrm{PGG}_{2}$ (Fig. 1.3). This endoperoxide is subsequently reduced to $\mathrm{PGH}_{2} . \mathrm{PGH}_{2}$, in turn, serves as the substrate for various prostaglandin synthases, which convert it to the corresponding prostaglandins. In connective tissue mast cells, $\mathrm{PGH}_{2}$ is predominantly converted into prostaglandin $\mathrm{D}_{2}\left(\mathrm{PGD}_{2}\right)$, through the action of PGD synthase. ${ }^{45}$ Other cyclooxygenase products derived from arachidonic acid, such as thromboxane $B_{2}, 6$ keto-PGF $1 \alpha$ and $\mathrm{PGF}_{2 \alpha}$, are also released by mast cells, but only in minor amounts. ${ }^{45}$ Besides by the cyclooxygenase pathway, arachidonic acid can also be oxygenated at different sites by specific lipoxygenases, resulting in the formation of hydroxy fatty acids (HETEs). Special attention needs to be paid to 5-lipoxygenase, which is responsible for the conversion of arachidonic acid into 5-HPETE (5-hydroperoxyeicosatetraenoic acid). This compound may be converted into 5-HETE (5-hydroxyeicosatetraenoic acid) or into leukotriene $\mathrm{A}_{4}\left(\mathrm{LTA}_{4}\right)$. In mucosal mast cells, the predominant arachidonic acidderived compound released is $\mathrm{LTC}_{4}$. This is in contrast to connective tissue mast cells, in which $\mathrm{PGD}_{2}$ is the predominant prostanoid released (also see Table 1.1.). The bronchoconstrictive actions of $\mathrm{LTC}_{4}$, together with those of histamine are known to be responsible for many of the clinical symptoms of asthma. By the action of various peptidases, $\mathrm{LTC}_{4}$ may be converted into other leukotrienes, such as $\mathrm{LTD}_{4}$ and $\mathrm{LTE}_{4}$, compounds which are less biologically active than the parent leukotriene, $\mathrm{LTC}_{4}$. The (patho-)physiological effects of arachidonic acid-derived metabolites are numerous and are briefly summarized in Table 1.3 . 
ARACHIDONIC ACID

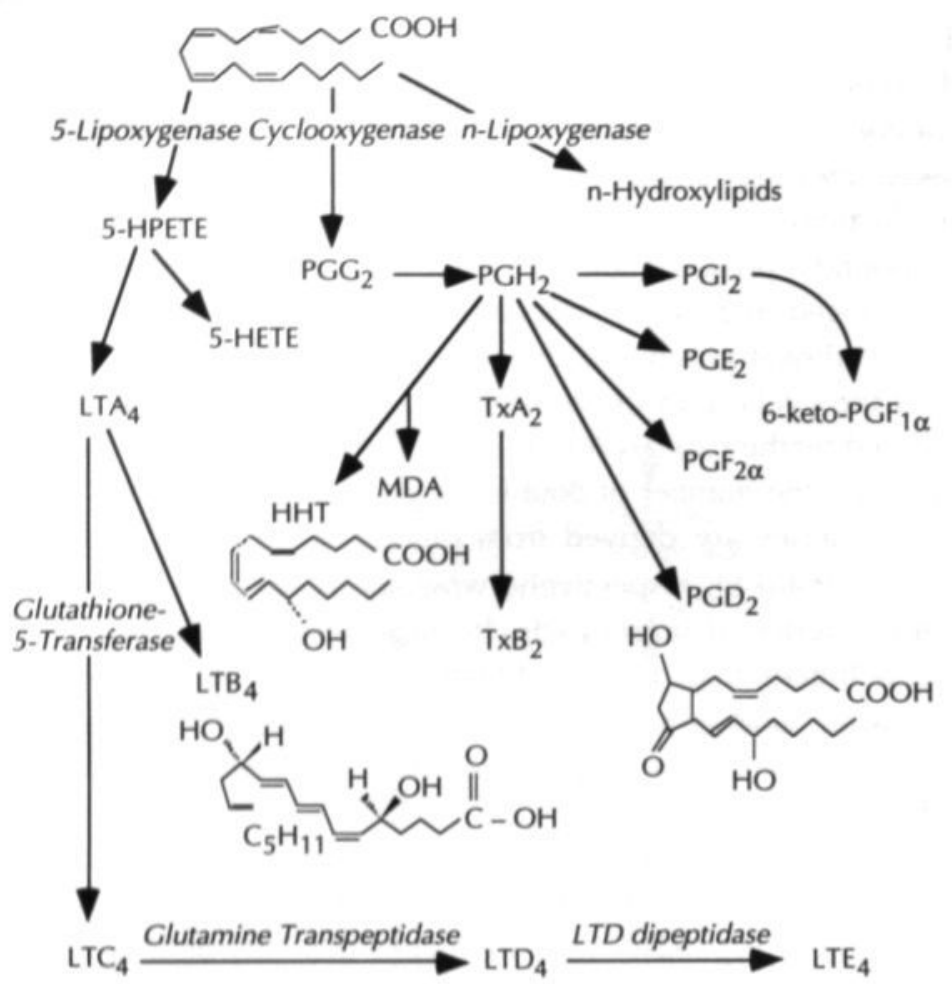

Figure 1.3: Biosynthesis of prostanoids, hydroxy fatty acids and leukotrienes

Table 1.3 Selected (Patho-)physiological Effects of Several Arachidonic Acid Metabolites

\section{Cyclooxygenase products}

$\mathrm{HHT}$

$\mathrm{PGl}_{2}$

$\mathrm{PGF}_{2 \alpha}$

$\mathrm{PGE}_{2}$

Lipoxygenase products

HHT

5-HETE

$\mathrm{LTC}_{4}$

\section{Action}

Chemotaxis

Inhibition of platelet aggregation

Bronchodilation

Bronchoconstriction

Increased mucus secretion

Increased vascular permeability

Vasodilation

Chemotaxis

Chemotaxis

Smooth muscle constriction

Increased vascular permeability

Chemotaxis

Adapted from Metcalfe et al. ${ }^{69}$ 


\subsection{Biochemical Events involved in Mast Cell Activation}

Mast cells in the peritoneal cavity of rats can easily be obtained by lavage. In contrast, the isolation of mast cells from tissues such as the skin and heart, requires enzymatic digestions and usually results in low yield and high impurity. In addition, functional responses of isolated tissue mast cells are often severely impaired. Since peritoneal mast cells share many similarities with those found in tissues, these cells are widely used instead. ${ }^{94}$ Because of their large size and since the degranulation process can easily be followed under the microscope, peritoneal mast cells have widely been used in patchclamp studies. Peritoneal mast cells may be activated by activated by two different pathways: the antigenic pathway, involving cross-linking of IgE-antibodies, and the nonantigenic pathway. The latter pathway is induced by naturally occurring peptides such as complement factor $\mathrm{C} 3 \mathrm{a}$, or by synthetic peptides such as compound $48 / 80$ and substance $P$.

\subsubsection{The Antigenic Pathway}

Immunological activation of mast cells occurs through cross-linking of IgE, bound to high-affinity $F_{c \varepsilon}$ receptors $\left(F_{c \varepsilon} R I\right)$ by the $F_{c}$ chain. The $F_{c \varepsilon} R I$ contain a glycosylated $\alpha$ chain exposed on the cell surface, a single $\beta$-chain, and two disulphide-linked $\boldsymbol{\gamma}$-chains. The interaction between IgE and its receptor is highly specific and does not result in mast cell activation: it is the cross-linkage of two IgE antibodies by antigen or by other compounds such as lectins, which initiates a series of biochemical events, ultimately resulting in activation of the exocytotic and eicosanoid synthetizing process. ${ }^{43}$ Antigen cross-linking results in the hydrolysis of phosphatidylinositol bisphosphate by phospholipase C (PLC), leading to the generation of diacylglycerol (DAG) and inositol $(1,4,5)$ trisphosphate (Ins $\left.(1,4,5) \mathrm{P}_{3}\right)$. DAG activates protein kinase C (PKC) which, in turn, phosphorylates various cellular proteins. Ins $(1,4,5) \mathrm{P}_{3}$ binds to a specific receptor on the endoplasmic reticulum, which results in mobilization of internal $\mathrm{Ca}^{2+}$. PLC may be activated by at least two different pathways, one involving $\mathrm{G}$ proteins and the other involving receptor or non-receptor protein tyrosine kinases. PLC activated by G proteins is commonly referred to as $\mathrm{PLC}_{\beta}$, whereas PLC activated by tyrosine kinases is commonly referred to as $\mathrm{PLC}_{\gamma} \cdot{ }^{57,85}$ The sequence of intracellular signal transduction events ultimately results in phosphorylation of cytoskeletal proteins involved in the translocation of secretory granules to the plasma membrane and activation of phospholipase $A_{2}$. The individual granule membranes then fuse with each other and with the plasma membrane, which results in exposure of the granule matrix to the extracellular environment. Activation of $\mathrm{PLA}_{2}$ results in the release of fatty acids, such as linoleic acid and arachidonic acid, from membrane phospholipids, which may be used as substrates for cyclooxygenase and/or lipoxygenase. Once formed intracellularly, prostanoids and hydroxy fatty acids are released into the extracellular environment by an as yet unknown mechanism. 


\subsubsection{The Non-antigenic Pathway}

A number of cationic peptides and polyamines have the capacity to activate mast cells via the 'non-antigenic' pathway. This pathway of mast cell activation is restricted to connective tissue mast cells, such as rat peritoneal and human skin mast cells. Triggers include positively charged peptides, such as mastoparan ${ }^{71}$, neuropeptides such as substance $\mathrm{P}^{70}$, peptidic hormones such as bradykinin ${ }^{17}$, natural and synthetic polyamines such as spermine and compound $48 / 80^{18,70}$, respectively, and compounds belonging to the blood complement cascade, such as $\mathrm{C}_{3} \mathrm{a}^{73}$

Many attempts have been made to delineate the receptors or targets of these mast cell triggers. It has become clear that the non-antigenic pathway of mast cell activation is independent of selective receptors, but involves a direct interaction of these triggers with specific G proteins. ${ }^{57}$ This interaction promotes a conformational change in specific $G$ proteins, which results in activation of $P L C_{\beta}$. Similar to the antigenic pathway, this is accompanied by the mobilization of $\mathrm{Ca}^{2+}$ from internal stores and activation of protein kinase $\mathrm{C}$, respectively. These intracellular changes, together with an increase of the $\mathrm{Ca}^{2+}$ concentration, ultimately result in initiation of the degranulation process and activation of PLA 2 . It should be noted that the activation of $\mathrm{G}$ proteins by peptides is mechanistically similar to their activation by receptors. ${ }^{40,72}$ Therefore, peptides and polyamines are generally used in studies on receptor/G protein interactions.

\subsection{Mast Cells and the Cardiovascular System}

\subsubsection{Localization and (Patho-)physiological Roles}

The heart contains a resident population of mast cells, located in the interstitium in the close vicinity of endothelial cells of small coronary vessels. ${ }^{79,90}$ Circulating histamine is taken up by the heart and is predominantly stored in mast cells. ${ }^{63}$ Therefore, the release of this compound is generally used as a marker to indicate the extent of mast cell degranulation.

Over the past three decades, it has become clear that in the heart, similar to most other organs, the restoration of aerobic perfusion after a period of ischemia, may induce additional injury. ${ }^{38}$ Besides an accelerated tissue necrosis, this, so-called 'reperfusioninduced injury', may also lead to a variety of other unfavourable events such as arrhythmias, ventricular fibrillations and stunning. The mechanisms underlying these phenomena have only partly been elucidated. Some possible causes are depletion of high-energy phosphate stores ${ }^{37}, \mathrm{Ca}^{2+}$ accumulation ${ }^{92}$, the activation of phospholipases ${ }^{49}$ and the production of lysophospholipids. ${ }^{21}$ In recent years, much attention has been paid as to the role of toxic oxygen free radicals (e.g. superoxide anions and hydroxyl radicals) in reperfusion-induced injury. It is thought that free radicals, generated during early reperfusion, react with polyunsaturated fatty acids within membranes, which results in loss of cellular function and integrity. ${ }^{22}$

In the isolated rat heart, reactive oxygen metabolites have been shown to induce massive mast cell degranulation. ${ }^{100}$ These findings are in agreement with early 
observations of Anrep et al. (1936) ${ }^{2}$, who discovered the release of histamine from the heart after hypoxemia in a canine heart-lung preparation. Since then, release of cardiac histamine has been found after coronary artery occlusion in $\operatorname{dog} s^{59,68}$, global ischemia in the isolated guinea pig heart ${ }^{66,67}$ and after complement 5a-induced myocardial ischemia in domestic pigs. ${ }^{47}$ Since mast cell degranulation may result in the release of potent harmful chemical mediators, such as proteinases, peroxidases and lysosomal enzymes, these observations have raised the question as to which extent mast cell degranulation during reperfusion, might be involved in reperfusion-induced myocardial injury. Until now, the evidence for a role of mast cells in myocardial injury is mainly based on the protective effects of the mast cell stabilizer lodoxamide tromethamine (U$42585 \mathrm{E})$. For instance, Jolly et $\mathrm{al} .{ }^{48}$ have shown that in a canine model of myocardial injury, lodoxamide significantly reduced the extent of myocardial injury, measured as ultimate infarct size at $24 \mathrm{~h}$ postmortem. In addition, Keller et al. ${ }^{50}$ have shown that in the isolated Langendorff-perfused rat heart, lodoxamide significantly reduced the release of both peroxidase (a proposed marker of mast cell degranulation) and creatine kinase (CK, a generally accepted marker of injury to cardiomyocytes) during reoxygenation.

Despite the widespread abundance of mast cells in the heart, surprisingly little is known about their possible (patho-)physiological roles. Since both histamine and heparin have been shown to enhance vascularization and endothelial cell proliferation in tissues such as the mesentery ${ }^{76}$, changes in the number of cardiac mast cells in the interstitial space, and/or changes in their rate of secretory activity have been suggested to be involved in the regulation of the adaptive growth capacity of the coronary microcirculation during maturation and ageing of the heart. ${ }^{27}$

\subsubsection{Leukocyte-Endothelium Interactions: Role of Mast cells?}

Extravasation of leukocytes is a multi-step process and a 'key-event' in inflammation. This process is initiated by the contact of leukocytes with the endothelium (i.e., leukocyte rolling) and is followed by firm adhesion and extravasation (Fig. 1.4). ${ }^{19,60}$ Leukocyte rolling is characterized by rapid formation and subsequent breakage of bonds mediated by selectins. ${ }^{9}$ Selectins belong to a family of three proteins, named L (leukocyte)-, P (platelet)-, and E (endothelial)-selectin, according to the cell type on which they were firstly described. These proteins are known to mediate the adhesive interactions between leukocytes and the endothelium and between leukocytes and platelets in the blood..$^{88}$ L-selectin is constitutively expressed on most leukocytes, whereas E-selectin is synthetized and expressed by endothelial cells after cytokine activation. ${ }^{1,10}$ P-selectin is stored in $\alpha$-granules of platelets and in Weibel-Palade bodies of endothelial cells, from where it can very rapidly be recruited to the plasma membrane by mediators such as histamine and thrombin. ${ }^{33,36}$ Each selectin recognizes specific carbohydrate sequences on either leukocytes (E-selectin or P-selectin) or the endothelium (L-selectin), and thereby mediates leukocyte-rolling. The transient nature of these adhesive interactions allows leukocytes to 'sample' the local endothelium for the presence of specific, additional, triggering factors that can activate leukocyte integrins (see below), which 
allow the cascade to proceed. In the absence of such factors, the transient nature of selectin binding allows leukocytes to disengage and move on.

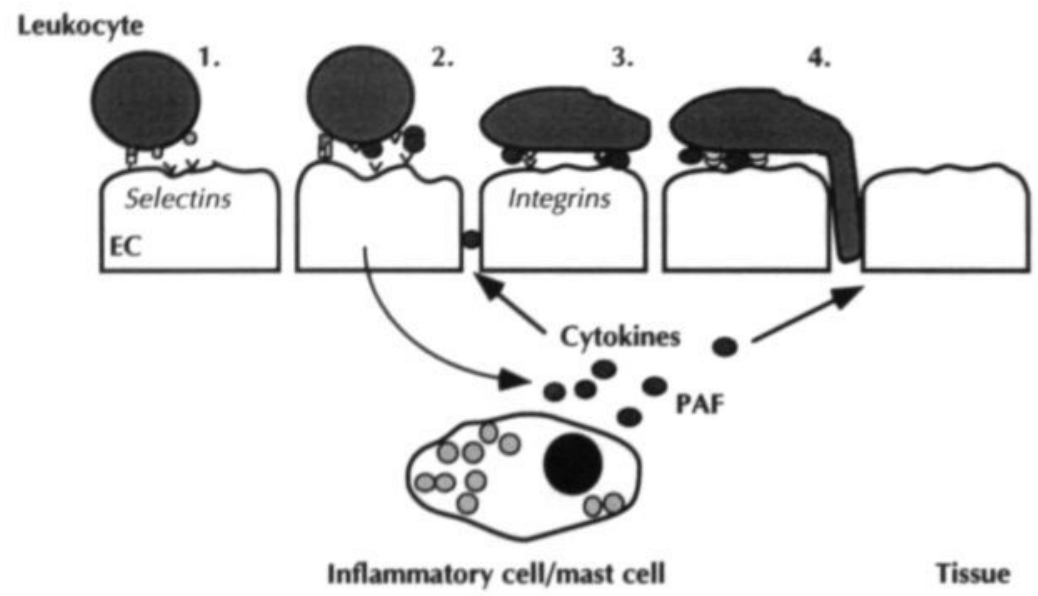

Figure 1.4: Sequential steps in adhesion of leukocytes to the endothelium

Leukocytes first 'roll' along the endothelium (1.), a process which is mediated by selectins. Activation of leukocyte integrins (2.) by PAF or various cytokines such as Interleukin-8, generated by underlying inflammatory cells (mast cells) or the endothelium itself, allows firm adhesion of leukocytes to the endothelium by interaction of leukocyte integrins with their corresponding counterparts on endothelial cells (3.). This interaction results in flattening of the leukocytes and is followed by extravasation of these cells under the influence of various chemotactic factors such as Interleukin-8 (4.).

Firm adhesion of leukocytes to the endothelium is mediated by a different set of adhesion molecules, called integrins. Integrins are a family of heterodimeric membrane glycoproteins that consist of an $\alpha$ and $\beta$ subunit and can be grouped into subfamilies based on their $\beta$ subunit. Most of the integrins require an activation step before they can bind to their respective ligands on the endothelium. Such an activation may occur through the release of platelet-activating factor (PAF) or by various interleukins such as interleukin-8 (IL-8), produced by the endothelium itself or by underlying inflammatory cells. ${ }^{105}$ The most potent integrins for cell-cell interactions are the $\beta 1$ integrins, such as VLA-4 ( ery L such as Mac-1 and LFA-1. VLA-4 is present on cells such as lymphocytes and monocytes and mediates binding of these cells to the endothelial adhesion receptor $\underline{V}$ ascular $\underline{\text { Cell }}$ Adhesion Molecule-1 (VCAM-1). ${ }^{89}$ LFA-1 is present on the surface of virtually all circulating leukocytes, whilst Mac-1 has a more limited distribution, being present on neutrophils, monocytes, macrophages, eosinophils and large granular lymphocytes. ${ }^{54}$ $\beta 2$ Integrins such as Mac-1 and LFA-1, bind to the Inter $\underline{\text { eellular }} \underline{\text { Adhesion }} \underline{\text { Molecule } 1}$ (ICAM-1). Expression of VCAM-1, like that of ICAM-1, on vascular endothelium is induced by proinflammatory cytokines such as TNF $\alpha .{ }^{8}$ Contacts like Mac-1:ICAM-1 or VLA-4:VCAM-1 result in flattening of the leukocytes and provide the basis for firm adhesion of these cells to the endothelium. Thereafter, the flattened leukocytes 
transmigrate into the extracellular matrix tissue by moving between endothelial cell junctions under the influence of chemotactic factors such as IL-8.

Mast cells may release a number of inflammatory mediators such as histamine, TNF $\alpha$, platelet activating factor (PAF) and various interleukins, such as IL- $8 .{ }^{31}$ Therefore, it has been speculated that tissue mast cells may contribute to events, ultimately resulting in leukocyte-adhesion and transmigration. In mice, degranulation of cutaneous mast cells by $\mathrm{lgE}$ or compound $48 / 80$ has been shown to cause neutrophil infiltration, a phenomenon which was markedly reduced in mast cell-deficient mice. ${ }^{95,103}$ In addition, it has been shown that superfusion of the hamster cheek pouch with compound $48 / 80$ caused leukocytes to leave the vasculature and migrate toward degranulating mast cells. ${ }^{82}$ In the heart in vivo, the infiltration of leukocytes in flowdeprived areas is known to increase ischemia/reperfusion-induced myocardial injury. $26,61,87$ Leukocytes may contribute to this kind of injury by the release of harmful substances such as proteases, oxygen free radicals and hydrogen peroxide by leukocytes, which may directly injure cardiac muscle cells. ${ }^{62}$ Until now, information about the role of mast cells in the extravasation of leukocytes in the heart is lacking.

\subsection{Aims and Outline of the Thesis}

In the present thesis, various aspects of mast cell activation and mediator release will be addressed. Special attention will be paid to the role of mast cells in the cardiovascular system. Since the isolation of mast cells from cardiac tissue is laborious and usually results in low yield and purity, we developed a method to isolate mast cells in high quantity from the peritoneal cavity. Cardiac mast cells, similar to peritoneal mast cells, belong to the connective tissue type. In order to quantitate the extent of mast cell degranulation, a fast and reliable high-performance liquid chromatographic (HPLC) method for the determination of histamine in biological samples was developed. Most of the HPLC techniques for the determination of histamine described until now make use of o-phtalaldehyde (OPA) as the derivatizing agent. Since OPA-derivatives are relatively unstable and require strict conditions for derivatization, we developed a method using fluorescamine as derivatizing agent, which resulted in relatively stable histamine-derivatives. The technique to isolate mast cells from the peritoneal cavity, as well as the HPLC technique and several of its applications are presented in Chapter 2.

When incorporated in phospholipids, certain long-chain, highly unsaturated fatty acids are not only important constituents of cellular membranes, but may also serve as substrates for the synthesis of prostanoids and hydroxy fatty acids. We were interested to know to which extent in mast cells the release of prostanoids and hydroxy fatty acids was influenced by diet-induced changes in membrane fatty acid composition. Therefore, peritoneal mast cells were isolated from rats which had been fed diets that differed in their fatty acid composition. The results of this study are presented in Chapter $\mathbf{3}$.

Studies in rat platelets have indicated that the type of dietary fat might also influence specific cellular processes and functions. ${ }^{39,44}$ We studied to which extent in mast cells, the extent of mast cell degranulation was influenced by the fatty acid composition of membrane phospholipids. Therefore, mast cells, isolated from diet- 
modified rats were activated with various concentrations of the $\mathrm{G}$ protein-activating compound 48/80. The results of this study are presented in Chapter 4.

A large number of studies have provided a great deal of information about specific steps of the signal transduction cascade, ultimately resulting in exocytosis and activation of the eicosanoid synthetizing pathway. However, the exact role of cytosolic calcium and protein tyrosine kinases in the release of histamine and $\mathrm{PGD}_{2}$ by these cells is not yet known. This was studied in peritoneal mast cells using a specific fluorescent $\mathrm{Ca}^{2+}$ probe and inhibitors of protein tyrosine kinases. The results of this study are presented in Chapter 5.

Indirect evidence from in vivo and ex vivo studies has indicated that mast cells are involved in acute injury to cardiomyocytes evoked by ischemia/reperfusion or hypoxia/reoxygenation. We investigated the role of mast cells in acute ischemia/ reperfusion-induced myocardial injury in a direct way. Therefore, Langendorff-perfused hearts, isolated from sensitized and non-sensitized rats, were subjected to ischemia/ reperfusion. During normoxic perfusion, preceding ischemia/reperfusion, hearts were administered a bolus-injection of antigen, known to result in a massive mast cell degranulation in sensitized hearts. ${ }^{101}$ Both control and 'mast cell depleted hearts' were subjected to ischemia/reperfusion. Lactate dehydrogenase (LDH) was used as a marker to indicate the extent of (irreversible) injury to cardiomyocytes. The results of this study are presented in Chapter 6.

In Chapter 7, the role of mast cells in another model of myocardial injury is described. Isolated, Langendorff-perfused hearts were subjected to hypoxia/ reoxygenation. Histamine was used as a marker for mast cell degranulation, whereas LDH and creatine kinase (CK) were used to indicate the extent of injury to cardiomyocytes. Special attention was paid to the use of peroxidase (PO) as a potential marker of mast cell degranulation.

Various studies in tissues other than the heart have indicated that products released from mast cells are involved in the process of leukocyte rolling/adhesion and/or extravasation. ${ }^{53,55,82,103}$ We approached the role cardiac mast cells in the expression of endothelial leukocyte-adhesion molecules in the intact heart with an in vitro rat experimental model. Peritoneal mast cells were studied for their capacity to induce the expression of leukocyte-adhesion molecules, such as ICAM-1, VCAM-1 and E-selectin, by cultured endothelial cells. The results of this study are described in Chapter $\mathbf{8}$.

Finally, the data obtained in various studies described in this thesis are summarized and placed in a broader perspective in Chapter $\mathbf{9 .}$

\subsection{REFERENCES}

1. Adams, D.H. and Shaw, S. (1994) Leukocyte-endothelial interactions and regulation of leukocyte migration. The Lancet 343, 831-836.

2. Anrep, G.V., Barsoum, G.S. and Talaat, M. (1936) Liberation of histamine by the heart muscle. J Physiol 86, 431-451.

3. Arai, K., Lee, F., Miyajima, A., Miyatake, S., Arai, N. and Yokota, T. (1990) Coordinators of immune and inflammatory responses. Ann rev Biochem 59, 783-836.

4. Arthus, M. (1903) Lésions cutanées produites par les injections de sérum de cheval chez le lapin anaphylactisé par et pour ce sérum. Comptes Rendus des Séances de la Société de Biologie et de ses Filiales 55, 1478-1480. 
5. Atkins, F.M., Friedman, M.M., Subba Rao, P.V. and Metcalfe, D.D. (1985) Interactions between mast cells, fibroblasts and connective tissue components. Int Arch Allergy Appl Immunol 77, 96102.

6. Barrett, K.E. and Metcalfe, D.D. (1984) Mast cell heterogeneity: evidence and implications. J Clin Immunol 4, 253-261.

7. Beutler, B. and Cerami, A. (1989) The biology of cachetin/TNF $\alpha$ - A primary mediator of the host response. Ann Rev Immunol 7, 625-655.

8. Bevilacqua, M.P. (1993) Endothelial-leukocyte adhesion molecules. Ann Rev Immunol 11, $767-$ 784.

9. Bevilacqua, M.P. and Nelson, R.M. (1993) Selectins. J Clin Invest 91, 379-387.

10. Bevilacqua, M.P., Stengelin, S., Gimbrone, M.A.J. and Seed, B. (1989) Endothelial leukocyteadhesion molecule-1: an inducible receptor for neutrophils related to complement regulatory proteins and lectins. Science 243, 1160-1165.

11. Black, J.W. and Shankley, N.P. (1987) How does gastrin act to stimulate oxyntic cell secretion? Trends Pharmacol Sci 8, 486-490.

12. Bland, C.E., Ginsburg, H., Silbert, J.E. and Metcalfe, D.D. (1972) Mouse heparin proteoglycan: synthesis by mast cell-fibroblast monolayers during lymphocyte-dependent mast cell proliferation. J Biol Chem 257, 8661-8666.

13. Blank, U., Ra, C., Miller, L., White, K., Metzger, H. and Kinet, J.P. (1989) Complete structure and expression in transfected cells of high affinity lgE receptor. Nature (London) 337, 187-192.

14. Brain, S.D. and Williams, T.J. (1989) In: Handbook of experimental pharmacology. Pharmacology of the skin, (Greaves, M.W. and Schuster, S., eds.), Vol. 87, pp. 347-366. Berlin: Springer-Verlag.

15. Braquet, P., Touqui, L., Shen, T.Y. and Vargaftig, B. (1987) Perspectives in platelet-activating factor research. Pharmacol Rev 39, 97-145.

16. Brenner, R.R. and Peluffo, R.O. (1969) Regulation of unsaturated fatty acid biosynthesis. I. Effect of unsaturated fatty acids of 18 carbons on the microsomal desaturation of linoleic acid into $\gamma$-linolenic acid. Biochim Biophys Acta 176, 471-479.

17. Bueb, J.L., Mousli, M., Bronner, C., Rouot, B. and Landry, Y. (1990) Activation of Gi-like proteins, a receptor-independent effect of kinins in mast cells. Mol Pharmacol 38, 816-822.

18. Bueb, J.L., Mousli, M. and Landry, Y. (1991) Molecular basis for cellular effects of naturally occurring polyamines. Agents Actions 33, 84-87.

19. Butcher, E.C. (1991) Leukocyte-endothelial cell recognition -three or more steps to specificity and diversity. Cell 67, 1033-1036.

20. Caughey, G.H. (1990) Tryptase and chymase in dog mast cells. Monogr Allergy 27, 67-89.

21. Corr, P.B., Snyder, D.W., Lee, B.I., Cross, R.W., Kein, C.R. and Sobel, B.E. (1982) Pathophysiological concentrations of lysophosphatides and the slow response. Am J Physiol 12, H187-H195.

22. Curtis, M.T., Gilfor, D. and Farber, J.L. (1984) Lipid peroxidation in increased order of microsome membranes. Arch Biochem Biophys 235, 644-649.

23. Dvorak, A.M. (1991) In: Blood Cell Biochemistry, (Harris, J.R., ed.), Vol. 4, pp. 3-25. New York: Plenum Press.

24. Ehrlich, P. (1878) Beiträge zur Theorie und Praxis der histologischen Färbung. Leipzig. Thesis University of Leipzig.

25. Enerbäck, L. (1981) The gut mucosal mast cell. Monogr Allergy 17, 222-232.

26. Engler, R.L., Dahlgren, M.D., Peterson, M.A., Dobbs, A. and Schmid-Schoenbein. (1986) Accumulation of polymorphonuclear leukocytes during 3-hour experimental myocardial ischemia. Am J Physiol 251, H93- $\mathrm{H} 100$.

27. Estensen, R.D. (1985) What is the role of myocardial mast cells? Hum Pathol 17, 536-538.

28. Farber, H.W. and Beer, D.J. (1991) Restricted secretion of a T-lymfocyte chemotactic cytokine by serotonin-stimulated cultured aortic endothelial cells. Circ Res 69, 257-265.

29. Folkman, J. (1986) How is blood vessel growth regulated in normal and neoplastic tissue? Cancer Res 46, 467-473.

30. Galli, S.J., Dvorak, A.M. and Dvorak, H.F. (1984) Basophils and mast cells: morphologic insights into their biology, secretory patterns and function. Prog Allergy 34, 1-25.

31. Galli, S.J., Gordon, J.R. and Wershil, B.K. (1993) Mast cell cytokines in allergy and inflammation. Agents Actions Suppl 43, 209-220.

32. Galli, S.J. and Lichtenstein, L.M. (1988) In: Allergy. Principles and Practice, (Middleton Jr., E., Reed, C.E., Ellis, E.F., Adkinson Jr., N.F. and Yunginger, J.W., eds.), Vol. 3, pp. 106-145. St. Louis: CV Mosby Company.

33. Geng, J.G., Bevilacqua, M.P., Moore, K.L., McIntyre, T.M., Prescott, S.M., Kim, J.M., Bliss, G.A., Zimmerman, G.A. and McEver, R.P. (1990) Rapid neutrophil adhesion to activated endothelium mediated by GMP-140. Nature 343, 757-760. 
34. Gotto, A.M., Pownall, H.J. and Havel, R.J. (1986) Introduction to the plasma lipoproteins. Methods Enzymol 128, 3-41.

35. Hamaguchy, Y., Kanakura, Y., Fujita, J., Takeda, S., Nakano, T., Tarui, S., Honjo, T. and Kitamura, Y. (1987) Interleukin-4 as an essential factor for in vitro clonal growth of murine connective tissue type mast cells. J Exp Med 165, 268-273.

36. Hattori, R., Hamilton, K.K., Fugate, R.D., McEver, R.P. and Sims, P.J. (1989) Stimulated secretion of endothelial von Willebrand factor is accompanied by rapid redistribution to the cell surface of the intracellular granule membrane protein GMP-140. J Biol Chem 264, 7768-7771.

37. Hearse, D.J. (1979) Oxygen deprivation and early myocardial contractile failure: a reassessment of the possible role of adenosine triphosphate. Am J Physiol 44, 1115-1121.

38. Hearse, D.J. and Bolli, R. (1993) Reperfusion-induced injury: manifestations, mechanisms and clinical relevance. Cardiovasc Res 26, 101-108.

39. Heemskerk, J.W.M., Feijge, M.A.H., Simonis, M.A.G. and Hornstra, G. (1995) Effects of dietary fatty acids on signal transduction and membrane cholesterol content in rat platelets. Biochim Biophys Acta 1255, 87-97.

40. Higashijima, T., Uzu, S., Nakajima, T. and Ross, E.M. (1988) Mastoparan, a peptide toxin from wasp venom, mimics receptors by activating GTP-binding regulatory proteins. I Biol Chem 263 , 6491-6494.

41. Hill, S.J. (1990) Distribution, properties and functional characteristics of three classes of histamine receptors. Pharmacol Rev 42, 45-83.

42. Hogaboam, C.M. and Wallace, J.L. (1992) Platelet activating factor synthesis by peritoneal mast cells and its inhibition by two quinoline based compounds. Br J Pharmacol 105, 87-92.

43. Holgate, S.T. and Church, M.K. (1982) Control of mediator release from mast cells. Clin Allergy (Suppl) 12, 5-13.

44. Hornstra, G. (1982) Dietary fats, prostanoids and arterial thrombosis. In: Effect of type and amount of dietary fats on arterial thrombus formation. Martinus Nijhoff Publishers, The Hague/Boston/London.

45. Hoverts, L.J., Lewis, R.A., Lawson, J.A., Sweetman, B.J., Austen, K.F., Oates, J.A. (1978) Arachidonic acid metabolism by rat mast cells. Prostaglandins 15, 717.

46. Hültner, L., Moeller, J., Schmitt, E., Jäger, G., Reisbach, G., Ring, J. and Dörmer, P. (1989) Thiolsensitive mast cell line derived from mouse bone marrow respond to a mast cell growthenhancing activity different from both IL-3 and IL-4. I Immunol 142, 3440-3446.

47. Ito, B.R., Engler, R.L. and Del Balzo, U. (1993) Role of cardiac mast cells in complement C5ainduced myocardial ischemia. Am J Physiol 264, $\mathrm{H} 1346-\mathrm{H} 1354$.

48. Jolly, S.R., Abrams, G.D., Romson, J.L., Baillie, M.B. and Lucchesi, B.R. (1982) Effects of lodoxamide on ischemic reperfused myocardium. J Cardiovasc Pharmacol 4, 441-448.

49. Katz, A.M. and Messineo, F.C. (1981) Lipid-membrane interactions and the pathogenesis of ischemic damage in the myocardium. Circ Res 48, 1-16.

50. Keller, A.M., Clancy, R.M., Barr, M.L., Marboe, C.C. and Cannon, P.J. (1988) Acute reoxygenation injury in the isolated rat heart: role of resident cardiac mast cells. Circ Res 63 , 1044-1052.

51. Kitamura, Y., Hatanaka, K., Murakami, M. and Shibata, H. (1979) Presence of mast cell precursors in peripheral blood of mice demonstrated by parabiosis. Blood 53, 1085-1088.

52. Kitamura, Y., Yokoyama, M., Matsuda, H., Ohno, T. and Mori, K.J. (1981) Spleen colony forming cell as common precursor for tissue mast cells and granulocytes. Nature 291, 159-160.

53. Klein, L.M., Lavker, R.M., Matis, W.L. and Murphy, G.F. (1989) Degranulation of human mast cells induces an endothelial antigen central to leukocyte adhesion. Proc Natl Acad Sci 86, 89728976.

54. Krensky, A.M., Sanchez-Madrid, F., Robbins, E., Nagy, J.A., Springer, T.A. and Burakoff, S.J. (1983) The functional significance, distribution and structure of LFA-1, LFA-2 and LFA-3: cell surface antigens associated with CTL-target interactions. J Immunol 131, 611-616.

55. Kubes, P. and Kanwar, S. (1994) Histamine induces leukocyte rolling in post-capillary venules, a P-selectin mediated event. I Immunol 152, 3570-3577.

56. Lagunoff, D., Philips, M.T., Iseri, O.A. and Benditt, E.P. (1964) Isolation and preliminary characterization of rat mast cell granules. Lab Invest 13, 1331-1339.

57. Landry, Y., Bronner, C., Mousli, M., Fischer, T. and Vallé, A. (1992) The activation of mast cells: molecular targets and transducing processes for antigenic and non-antigenic stimuli. Bull Inst Pasteur 90, 83-98.

58. Lee, F., Yokota, T., Otsuka, T., Meyerson, P., Villaret, D., Coffman, R., Mosmann, T., Rennick, D., Roehm, N., Smith, C., Zlotnik, A. and Arai, K. (1983) Isolation and characterization of a mouse interleukin CDNA clone that expresses B-cell stimulatory factor 1 activities and $T$-cell- and mast cell-stimulating activities. Proc Natl Acad Sci USA 83, 2061-2065.

59. Levi, R., Wolff, A., Robertson, D.A. and Graver, L.M. (1985) IgE-mediated hypersensitivity and ischemia as causes of endogenous cardiac histamine release. Adv Biosci 51, 305-307. 
60. Ley, K. (1989) Granulocyte adhesion to microvascular and cultured endothelium. Stud Biophys 134, 179-184.

61. Lucchesi, B.M. (1990) Modulation of leukocyte-mediated myocardial reperfusion injury. Annu Rev Physiol 52, 561-568.

62. Lucchesi, B.R., Werns, S.W. and Fantone, J.C. (1989) The role of the neutrophil and free radicals in ischemic myocardial injury. J Mol Cell Cardiol 21, 1241-1251.

63. Mannaioni, P.F., Gianella, E., Palmerani, B., Gambassi, F., Bani-Sacchi, T. and Masini, E. (1988) Free radicals as endogenous histamine releasers. Agents Actions 23, 129-142.

64. Marone, G., Casolaro, V., Cirillo, R., Stellato, C. and Genovese, A. (1989) Pathophysiology of human basophils and mast cells in allergic disorders. Clin Immunol Immunopathol 50, 524-540.

65. Marshall, J.S., Gauldie, J., Nielsen, L. and Bienenstock, J. (1993) Leukemia-inhibitory factor production by rat mast cells. Eur I Immunol 23, 2116-2135.

66. Masini, E., Bianchi, S., Gambassi, F., Palmerani, B., Pistelli, A., Carlomagno, L. and Mannaioni, P.F. (1990) Ischemia/reperfusion injury and histamine release in isolated and perfused guinea-pig heart: pharmacological interventions. Agents Actions 30, 198-201.

67. Masini, E., Gambassi, F., Palmerani, B., Carlomagno, L. and Mannaioni, P.F. (1989) Ischemia/reperfusion injury and histamine-release in isolated guinea pig heart: the role of free radicals. Agents Actions 27, 154-157.

68. Masini, E., Planchenault, J., Pezziardi, F., Gautier, P. and Gagnol, J.P. (1985) Histamine release during an experimental coronary thrombosis in awake dog. Agents Actions 16, 227-230.

69. Metcalfe, D.D., Kaliner, M. and Donlon, M.A. (1981) The mast cell. CRC Crit Rev Immunol 3.

70. Mousli, M., Bronner, C., Bockaert, J., Rouot, B. and Landry, Y. (1990) Substance P, compound $48 / 80$ and mastoparan interact with C-terminals of $G$ proteins. Immunol Lett 25, 355-358.

71. Mousli, M., Bronner, C., Bueb, J.L., Tschirhart, E., Gies, J.P. and Landry, Y. (1989) Activation of rat peritoneal mast cells by substance $P$ and mastoparan. J Pharmacol Exp Ther 250, 329-335.

72. Mousli, M., Bueb, J.L., Bronner, C., Rouot, B. and Landry, Y. (1990) G protein activation: a receptor-independent mode of action for amphiphilic neuropeptides and venom peptides. Trends Pharmacol Sci 11, 358-362.

73. Mousli, M., Fischer, T., Landry, Y. and Bronner, C. (1992) A mechanism of action for anaphylatoxin C3a stimulation of mast cells. I Immunol 148, 2456-2461.

74. Nakahata, T. and Ogawa, M. (1982) Identification in culture of a class of hemopoietic colonyforming units with extensive capability to self-renew and generate multipotential hemopoietic colonies. Proc Natl Acad Sci USA 79, 3843-3847.

75. Needleman, P., Raz, A., Minkes, M.S., Ferrendelli, J.A. and Sprecher, H. (1979) Triene prostaglandins: prostacyclin and thromboxane biosynthesis and unique biological properties. Proc Natl Acad Sci USA 76, 944-948.

76. Norrby, K., Jakobsson, A. and Sorbo, J. (1986) Mast cell mediated angiogenesis: a novel experimental model using the rat mesentery. Cell Pathol 52, 195-206.

77. Pearce, F.L. (1991) Biological effects of histamine: an overview. Agents Actions 33, 4-7.

78. Perdue, M.H., Ramage, J.K., Burget, D., Marshall, J. and Masson, S. (1989) Intestinal mucosal injury is associated with mast cell activation and leukotriene generation during Nippostrongylusinduced inflammation in the rat. Dig Dis Sci 34, 724-731.

79. Pollak, O.J. (1957) Mast cells in the circulatory system of man. Circulation 16, 1084-1089.

80. Portier, P. and Richet, C. (1902) De l'action anaphylactique de certaines venims. Comptés Rendus des Séances de la Societé de Biologie et de ses Filiales 54, 170-172.

81. Prausnitz, C. and Kustner, H. (1921) In: Clinical aspects of immunology, (Gell, P.G.H. and Coombs, R.R.A., eds.), Vol. 86, pp. 160-169. Oxford: Blackwood Scientific.

82. Raud, J., Lindbom, L., Dahlen, S.-E. and Hedqvist, P. (1989) Periarteriolar localization of mast cells promotes oriented interstitial migration of leukocytes in the hamster cheek pouch. Am J Pathol 134, 161-166.

83. Razin, E., Stevens, R.L., Akiyama, F., Schmid, K. and Austen, K.F. (1982) Culture from mouse bone marrow of a subclass of mast cells possessing a distinct chondroitin sulfate proteoglycan with glycosaminoglycans rich in $\mathrm{N}$-acetylgalactosamine-4,6-disulfate. J Biol Chem 257, 7229 7236.

84. Riley, J.F. and West, G.B. (1953) The presence of histamine in tissue mast cells. J Physiol (London) 120, 528-537.

85. Riscovitch, M. (1992) Crosstalk among multiple signal-activated phospholipases. TIBS 17, 393 399

86. Roitt, I., Brostoff, J. and Male, D. (1993) Essential Immunology, Edinburgh: Churchill Livingstone.

87. Romson, J.L., Hook, B.G., Kunkel, S.L., Abrams, G.D., Schork, M.A. and Lucchesi, B.R. (1983) Reduction of the extent of ischemic myocardial injury by neutrophil depletion in the dog. Circulation 67, 1016-1023.

88. Rosen, S.D. and Bertozzi, C.R. (1994) The selectins and their ligands. Curr Opin Cell Biol 6, 663673. 
89. Rothlein, R., Marlin, S.D., Rothlein, R., Lawrence, M.B., McIntire, L.V. and Anderson, D.C. (1990) In: Leukocyte adhesion molecules. Structure, function and regulation, (Springer, T.A., Anderson, D.C., Rosenthal, A.S. and Rothlein, R., eds.), pp. 170-189. New York: SpringerVerlag.

90. Rydsynski, H., Dalen, H., Saetersdal, T. and Engedal, H. (1987) Morphologic and morphometric analysis of the mast cells in human heart biopsies. Agents Actions 20, 288-289.

91. Salvemini, D., Masini, E., Pistelli, A., Mannaioni, P.F. and Vane, J.R. (1991) Nitric oxide: a regulatory mediator of mast cell reactivity. J Cardiovasc Pharmacol 17, S258-S264.

92. Schrader, J. (1985) Mechanisms of ischemic injury in the heart. Basic Res Cardiol 80 (suppl. 2), 135-139.

93. Schwartz, L.B. and Austen, K.F. (1984) Structure and function of the chemical mediators of mast cells. Prog Allergy 34, 271-285.

94. Swieter, M., Mergenhagen, E. and Siraganian, R.P. (1992) Microenvironmental factors that influence mast cell phenotype and function. Proc Soc Exp Biol Med 199, 22-33.

95. Tannenbaum, S., Oertel, H., Henderson, W. and Kaliner, M. (1980) The biologic activity of mast cell granules. I. Elicitation of inflammatory responses in rat skin. J Immunol 125, 325-331.

96. Thompson-Snipes, L., Dhar, V., Bond, M.W., Mosmann, T.R., Moore, K.W. and Rennick, D.M. (1991) Interleukin-10: a novel stimulatory factor for mast cells and their progenitors. J Exp Med 173, 507-510.

97. Tsai, M., Takeishi, T., Thompson, H., Langley, K.E., Zsebo, K.M., Metcalfe, D.D., Geissler, E.N. and Galli, S.J. (1991) Induction of mast cell proliferation, maturation, and heparin synthesis by the rat c-kit ligand, stem cell factor. Proc Natl Acad Sci USA 88, 6382-6386.

98. Undem, B.J. and Weinreich, D. (1989) In: Neuroimmune networks: physiology and disease, (Goetzl, E.J. and Spector, N.H., eds.), pp. 155-162. New York: Alan Liss.

99. Unna, P.G. (1894) Histopathologie der Hautkrankheiten in Miliania Syphilide. Hamburg: Leopold Voss.

100. Vandeplassche, G., Bernier, M., Thone, F., Borgers, M., Kusama, Y. and Hearse, D.J. (1990) Singlet oxygen and myocardial injury: ultrastructural, cytochemical and electrocardiographic consequences of photoactivation of rose bengal. J Mol Cell Cardiol 22, 287-301.

101. Vleeming, W., van Rooij, H.H., Wemer, J. and Porsius, A.J. (1991) Characterization and modulation of antigen-induced effects in isolated rat heart. J Cardiovasc Pharmacol 18, 556-565.

102. Wells, E., Harper, S.T., Jackson, C.G., Mann, J. and Eady, R.P. (1986) Characterization of primate bronchoalveolar mast cells: IgE-dependent release of histamine, leukotrienes, and prostaglandins. J Immunol 137, 3933-3940.

103. Wershil, B.K., Wang, Z.S., Gordon, J.R. and Galli, S.J. (1991) Recruitment of neutrophils during IgE-dependent cutaneous late phase responses in the mouse is mast cell-dependent: partial inhibition of the reaction with antiserum against tumor necrosis factor alpha. J Clin Invest 87 , 446-453.

104. Young, J., Liu, C.C., Butler, G., Cohn, Z.A. and Galli, S.J. (1987) Identification, purification and characterization of a mast cell-associated cytolytic factor related to tumor necrosis factor $\alpha$. Biochemistry 19, 5799-5804.

105. Zimmerman, G.A., Prescott, S.M. and Mclntyre, T.M. (1992) Endothelial cell interactions with granulocytes: tethering and signaling molecules. Immunol Today 13, 93-99. 


\section{ICHAPTER 2}

\section{A High-Performance Liquid Chromatographic Method for the Determination of Histamine in Biological Samples: \\ An improved Technique to Isolate Peritoneal Mast Cells}

Parts of this chapter have been published in:

Charles M.C.J. van Haaster, Wim Engels, Paul J.M.R. Lemmens, Gerard Hornstra and Ger J. Van der Vusse

Rapid and highly sensitive high-performance liquid chromatographic method for the determination of histamine and 3-methyl histamine in biological samples using fluorescamine as the derivatizing agent

J. Chrom. (1993) 617:233-240 


\subsection{ABSTRACT}

A highly sensitive and rapid HPLC assay for the determination of histamine and 3methyl histamine in biological samples using 1-methyl histamine as the internal standard is described. Samples were purified and concentrated on cation-exchange columns and derivatized with fluorescamine. The lower detection limit was $20 \mathrm{pg}$ on column. Linearity was demonstrated up to $20 \mathrm{ng}$ on column. The samples could be derivatized simultaneously before injection on HPLC and were stable for at least 7 days. The method was used for the determination of histamine and related compounds in coronary effluents, extracts of homogenized rat hearts and supernatants from stimulated peritoneal mast cells. In addition, a simple method to isolate mast cells in high purity from the peritoneal cavity is also described.

\subsection{INTRODUCTION}

Histamine, stored in secretory granules of mast cells, is known to be responsible for some of the clinical symptoms of immediate hypersensitivity reactions and asthma. ${ }^{16}$ Upon activation, histamine is rapidly released into the extracellular environment. Therefore, this compound is generally used as a marker to indicate the extent of mast cell degranulation. A number of analytical methods for the determination of histamine have been described. These include bioassays ${ }^{1}$, fluorometry 9,21 , radioenzymatic assays $^{4,5}$ and gas chromatography-mass spectrometry. ${ }^{11,15}$ Most of these techniques, however, suffer from disadvantages such as low specificity and sensitivity, and the possible appearance of contamination. Therefore, various methods to determine histamine by High Performance Liquid Chromatography (HPLC) have been developed, which give accurate and rapid results. ${ }^{2,3,17-19}$ Most of these methods make use of ophtalaldehyde (OPA) as the derivatizing agent, which results in histamine-derivatives which are rather instable. This has the disadvantage that rather sophisticated and expensive HPLC equipments, for instance those using on-or post-column derivatization, are required. We developed a method for the determination of histamine in biological samples, which resulted in relatively stable derivatives and which required only an ordinary HPLC apparatus. Since concentrations of histamine in biological samples, for instance in coronary effluents (see Chapter 7 , may be very low, a concentration-step prior to analysis was introduced.

In vivo, trauma and lethal stress in rats may result in the formation of 3-methyl histamine from histamine. ${ }^{8}$ In order to quantitate the possible formation of 3-methyl histamine in rat heart, this compound was also included in the present method. The method was used to determine the content of histamine and 3-methyl histamine in rat heart homogenates and coronary effluents. In addition, the technique was used to determine the histamine content of peritoneal mast cells.

In most of the techniques for the isolation of peritoneal mast cells described until now, erythrocytes usually contaminate the final mast cell preparation, which might influence the outcome of studies with preparations assumed to be pure. Since the presence of erythrocytes in the mast cell preparation might result in erroneous data 
concerning the fatty acid composition of mast cell phospholipids (see Chapter 3), a method to separate these cells from mast cells was developed. This technique is also described in this chapter.

\subsection{MATERIALS AND METHODS}

\section{Chemicals}

Histamine, 3-methyl histamine and 1-methyl histamine were obtained from Sigma (St. Louis, USA). Bakerbond Carboxylic acid $(\mathrm{COOH}) 40 \mu \mathrm{m}, 60 \AA$, bulk package, was obtained from Baker Inc., (Philipsburg, USA). $\mathrm{NaH}_{2} \mathrm{PO}_{4} \cdot \mathrm{H}_{2} \mathrm{O}, \mathrm{HCl}$ (Suprapur $\left.{ }^{(}\right)$), gelatin, $\mathrm{CaCl}_{2} .2 \mathrm{H}_{2} \mathrm{O}, \mathrm{Na}_{2} \mathrm{EDTA}, \mathrm{NH}_{4} \mathrm{OH}$, o- $\mathrm{H}_{3} \mathrm{PO}_{4}$ and $\mathrm{HClO}_{4}$ (all analytical grade) were obtained from Merck (Darmstadt, FRG). Acetonitrile and methanol (HPLC-grade) were purchased from Rathburn (Walkerburn, UK). Triethylamine, purified before use on short tip-plugged pasteur pipettes filled with $\mathrm{Al}_{2} \mathrm{O}_{3}$ (ICN Biomedicals Inc., Costa Mesa, USA), was obtained from Janssen Chimica (Tilburg, the Netherlands). Fluorescamine was from Fluka AG (Buchs, Switzerland). Metrizamide ${ }^{\circledR}$ was purchased from Nyegaard \& Co. (Oslo, Norway). Heparin (Thromboliquine ${ }^{\circledR}$ ) was obtained from Organon Teknika (Boxtel, the Netherlands). Water was purified with a milli-Q purification unit from Millipore (Bedford, USA). Compound 48/80 (a condensation product of N-methyl-pmethoxy-phenethylamine with formaldehyde) was a kind gift from dr. M. Borgers (Janssen Pharmaceutica, Beerse, Belgium).

\section{Purification and Concentration of the Samples}

Small columns were prepared with a slurry of Bakerbond Carboxylic acid material in methanol ( $150 \mathrm{mg} /$ column) in pasteur pipettes tip-plugged with glassfibre prefilter material (Satorius, Göttingen, FRG). The columns were washed with $2 \mathrm{ml} \mathrm{of} \mathrm{H}_{2} \mathrm{O}$ followed by $2 \mathrm{ml}$ of $1 \mathrm{M} \mathrm{HCl}, 2 \mathrm{ml}$ of $\mathrm{H}_{2} \mathrm{O}$ and $4 \mathrm{ml}$ of $0.2 \mathrm{M}$ sodium phosphate buffer, $\mathrm{pH}$ 6.4. After addition of $500 \mathrm{ng}$ of 1 -methyl histamine as internal standard, samples (brought to $\mathrm{pH} 6.4$ with phosphate buffer) were applied onto the columns. Columns were washed with $4 \mathrm{ml}$ of $50 \mathrm{mM} \mathrm{Na}{ }_{2}$ EDTA, $\mathrm{pH} 6.4$ and $4 \mathrm{ml}$ of $\mathrm{H}_{2} \mathrm{O}$. Histamine, 3methyl histamine and 1-methyl histamine were eluted with $1 \mathrm{ml}$ of $1 \mathrm{M} \mathrm{HCl}$. The eluate was dried under a stream of nitrogen at $40{ }^{\circ} \mathrm{C}$ for approximately $15 \mathrm{~min}$ and the residue was subsequently dissolved in $100 \mu \mathrm{l}$ of $\mathrm{H}_{2} \mathrm{O}$.

\section{Derivatization}

To the purified samples, $400 \mu \mathrm{l}$ of $50 \mathrm{mM}$ sodium borate-buffer, $\mathrm{pH} 9.1$ was added. Under continuous, vigorous stirring, $500 \mu \mathrm{l}$ of a freshly prepared fluorescamine solution in acetonitrile $(20 \mathrm{mg} / 100 \mathrm{ml})$ was added. After stirring for $1 \mathrm{~min}$, the derivatized samples were dried under a stream of nitrogen at $40{ }^{\circ} \mathrm{C}$ for approximately $15 \mathrm{~min}$. The residues were dissolved in $1 \mathrm{ml}$ of the HPLC mobile phase (see below).

Fluorescamine reacts with compounds possessing a primary amino group almost instantaneously at room temperature in aqueous solution at $\mathrm{pH} 7.5$ to $9 .^{12}$ The excess of fluorescamine is rapidly hydrolyzed ( $t_{1 / 2}$ is about 10 seconds) to yield a water-soluble, 
non-fluorescent, product. The derivatization reactions of histamine, 1-methyl and 3methyl histamine with fluorescamine are shown in Fig. 2.1.

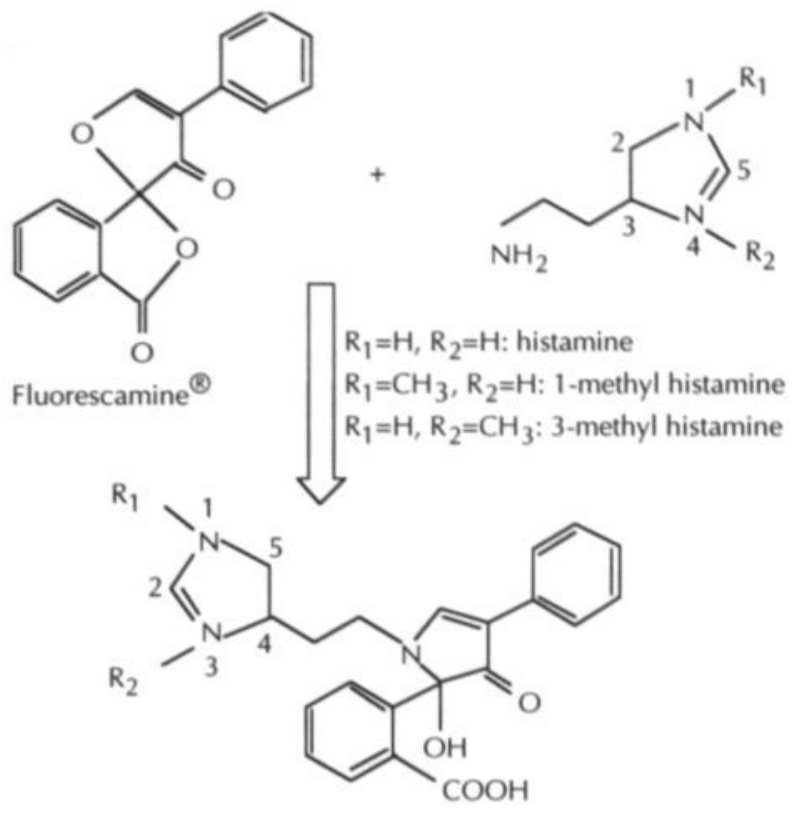

Figure 2.1: Derivatization of histamine, 1-methyl or 3-methyl histamine with fluorescamine ${ }^{\circledR}$

\section{HPLC Instrumentation}

The HPLC system consisted of a Spectroflow 400 pump (Kratos Analytical, Ramsey, USA), a Promis auto-injector (Spark Holland, the Netherlands) with a Rheodyne 7010 injection valve and a Perkin-Elmer LS-1 fluorescence detector (Beaconsfield, UK) with a reversed-phase C18-column, $250 \times 4$ mm I.D., $5 \mu \mathrm{m}$ particles (Chrompack, Middelburg, the Netherlands). The injection volume was $20 \mu \mathrm{l}$ and the flow rate $0.7 \mathrm{ml} / \mathrm{min}$. The fluorescence detector had the following settings: excitation wavelength, $360 \mathrm{~nm}$; emission wavelength, $440 \mathrm{~nm}$. The temperature of the HPLC column was kept at 20 ${ }^{\circ} \mathrm{C}$. Samples were kept at $4{ }^{\circ} \mathrm{C}$ in the auto-injector device in the dark. Data were acquired with Rainin software, using the Dynamax program for integration of the chromatograms (Rainin Instrument Co., Ridgefield, USA).

\section{Chromatographic Conditions}

The HPLC mobile phase consisted of $\mathrm{H}_{2} \mathrm{O} /$ acetonitrile/triethylamine/o- $\mathrm{H}_{3} \mathrm{PO}_{4}$ (850/150/4/4, v/v) brought to $\mathrm{pH} 6.4$ with $\mathrm{NH}_{4} \mathrm{OH}$. In order to obtain an optimal response of the fluorescence detector and a low noise level, the mobile phase was gassed daily with helium $(5 \mathrm{~min}$ at a flow rate of $250 \mathrm{ml} / \mathrm{min}$ for each $1000 \mathrm{ml}$ of the mobile phase). 
Assessment of Linearity, Stability, Reproducibility and Recovery

The relationship between the amounts of fluorescamine-derivatized histamine or 3methyl histamine injected on column and their relative peak areas was assessed as

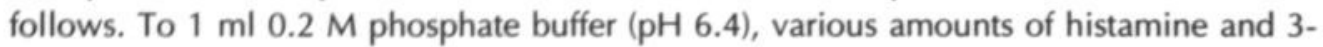
methyl histamine standard solutions $(0,100,200,300,400,500,600$ and $700 \mathrm{ng}$, each amount prepared in triplicate) were added. To all samples $500 \mathrm{ng} 1$-methyl histamine was added. After concentration and derivatization of the samples, the derivatives were dissolved in $1 \mathrm{ml}$ of the HPLC mobile phase. Following injection of $20 \mu \mathrm{l}$ of the samples (corresponding to 0 to $14 \mathrm{ng}$ on column) and separation by HPLC, absolute peak areas of histamine and 3-methyl histamine were transformed to relative peak areas by correction for the internal standard. Samples were immediately analyzed after derivatization (day 0 ) and re-analyzed on day 1 and 7.

For the determination of the stability, samples $(n=12)$ from a standard solution, containing histamine (300 ng), 3-methyl histamine (300 ng) and 1-methyl histamine (250 ng), were concentrated, derivatized and analyzed by HPLC on day 0 and day 7 .

In order to determine the reproducibility, two standard solutions (I and II) were prepared. Standard solution I contained $1500 \mathrm{ng} / \mathrm{ml}$ histamine, $1500 \mathrm{ng} / \mathrm{ml} \mathrm{3-methyl}$ histamine and $3000 \mathrm{ng} / \mathrm{ml}$ of the internal standard. Standard solution II contained 6000 $\mathrm{ng} / \mathrm{ml}$ histamine, $6000 \mathrm{ng} / \mathrm{ml}$ 3-methyl histamine and $3000 \mathrm{ng} / \mathrm{ml}$ of the internal standard. On three consecutive days, $100 \mu \mathrm{l}$ samples $(n=6)$ were withdrawn from solutions I and II. Samples were brought onto the cation-exchange columns in $2 \mathrm{ml} 0.2$ $M$ sodium phosphate buffer ( $\mathrm{pH}$ 6.4). After sequential wash-steps and elution with $\mathrm{HCl}$, samples were dried, redissolved in borate buffer, derivatized with fluorescamine and immediately analyzed by HPLC.

To determine the recovery of the purification/concentration procedure, $100 \mu \mathrm{l}$ samples from solution I $(n=10)$ were immediately derivatized with fluorescamine, solubilized in $1 \mathrm{ml}$ of the mobile phase and analyzed by HPLC. Absolute peak areas of these samples were compared to the absolute peak areas from the samples concentrated on cation-exchange columns.

\section{Samples Rat Heart Homogenates}

Histamine and 3-methyl histamine were determined in heart homogenates from Lewis rats $(n=9)$. In order to remove blood from the tissue, hearts were perfused for $5 \mathrm{~min}$ according to Langendorff. ${ }^{13}$ After heparinization (1000 IU/kg, intraperitoneally), hearts were isolated and perfused according to Langendorff at a constant pressure of $80 \mathrm{~mm}$ $\mathrm{Hg}$. The perfusion fluid was Krebs-Ringer's solution ( $\mathrm{pH} 7.4$ ) containing (in $\mathrm{mM}$ ): $\mathrm{NaCl}$ (130), $\mathrm{KCl}$ (5.6), $\mathrm{MgCl}_{2}$ (1.2), $\mathrm{NaH}_{2} \mathrm{PO}_{4}$ (1.2), $\mathrm{NaHCO}_{3}$ (28.6), $\mathrm{CaCl}_{2}$ (2.2), and glucose (11.1). The buffer was kept at $37{ }^{\circ} \mathrm{C}$ and was equilibrated with $95 \% \mathrm{O}_{2} / 5 \% \mathrm{CO}_{2}(\mathrm{v} / \mathrm{v})$ throughout the experiment, which always resulted in a final $\mathrm{pO}_{2}>80 \mathrm{kPa}$. After $5 \mathrm{~min}$ perfusion was stopped and parts (about $200 \mathrm{mg}$ ) of the ventricular tissue were brought into ice-cold $50 \mathrm{mM}$ Tris. $\mathrm{HCl}$ buffer $(\mathrm{pH} 8.5)$ to a final concentration of $5 \%(\mathrm{w} / \mathrm{v})$. After addition of the internal standard, hearts were minced and subsequently homogenized with the use of an Ultra-Turrax (Wilten Woltil, De Bilt, the Netherlands). Thereafter, samples were sonicated ( 30 Watt, amplitude $12 \mu$, peak to peak) with an MSE sonifier 
(Crawley, UK) for 2 min with repeated intervals of $5 \mathrm{~s}$. During homogenization and sonication, samples were kept on ice. After addition of $\mathrm{HClO}_{4}$ to a final concentration of $0.3 \mathrm{M}$, samples were boiled for $5 \mathrm{~min}$ at $100{ }^{\circ} \mathrm{C}$. Thereafter, samples were neutralized with $\mathrm{KOH}$, cooled to $0{ }^{\circ} \mathrm{C}$ and centrifuged at $2,000 \times \mathrm{g}$ for $5 \mathrm{~min}\left(4^{\circ} \mathrm{C}\right)$ to remove the precipitate of $\mathrm{KClO}_{4}$. Supernatants were collected and stored at $-20{ }^{\circ} \mathrm{C}$ until analysis.

\section{Samples of Coronary Effluents}

In a subset of experiments, histamine and 3-methyl histamine were determined in coronary effluents collected from hearts from Lewis rats $(n=3)$. After 5 min of normoxic perfusion, hearts were administered a bolus-injection of $50 \mu \mathrm{g}$ of compound $48 / 80$ (dissolved in $0.5 \mathrm{ml}$ perfusion buffer) in order to induce mast cell degranulation. Coronary effluents were collected during the following period of $1 \mathrm{~min}$.

\section{Purification of Peritoneal Mast Cells}

Peritoneal mast cells were isolated according to a modified version of the procedure of Schwartz et al. ${ }^{20}$ Rats were anaesthetized with diethyl ether and $20 \mathrm{ml}$ of lavage buffer, composed of $136 \mathrm{mM} \mathrm{NaCl}, 2.7 \mathrm{mM} \mathrm{KCl}, 8.1 \mathrm{mM} \mathrm{Na} 2 \mathrm{HPO}_{4}, 1.5 \mathrm{mM} \mathrm{KH}_{2} \mathrm{PO}_{4}$, gelatin $(0.1 \%, w / v)$ and heparin $(10$ I.E./ml), $\mathrm{pH} 7.4$, was injected intraperitoneally. The abdomen was massaged for about $1 \mathrm{~min}$ and the peritoneal exudate was recovered. After centrifugation at $195 \times \mathrm{g}$ for $5 \mathrm{~min}$, cells were washed twice with lavage buffer and resuspended into a final volume of $1 \mathrm{ml}$. The cell suspension was layered onto $2.5 \mathrm{ml}$ of a $22.5 \%$ metrizamide gradient $(w / v)$ in lavage buffer (Fig. 2.2) and centrifuged at $470 \times g$ for $15 \mathrm{~min}$. This resulted in a complete separation of mast cells and erythrocytes from other nucleated cells. After carefully removing the interphase, the sediment was washed twice with lavage buffer and resuspended into a final volume of $1 \mathrm{ml}$. Since erythrocytes have a density range $(d=1.10$ to 1.12$)$ which overlaps the lower range of densities of mast cells ( $d=1.09$ to 1.17 ), another step is needed to completely separate these cells. Therefore, a velocity gradient was introduced, which allowed separation of the cells by their differences in cell size rather than in density. ${ }^{6}$ This was achieved by layering the cell suspension $(1 \mathrm{ml})$ onto a two-step $3 \% / 9 \%(\mathrm{w} / \mathrm{v})$ metrizamide gradient. This gradient was centrifuged at $50 \times \mathrm{g}$ for $10 \mathrm{~min}$. This resulted in an interphase containing erythrocytes, and a sediment containing mast cells. The sediment was washed twice with buffer $\mathrm{pH} 7.4$, containing $136 \mathrm{mM} \mathrm{NaCl}, 2.7 \mathrm{mM} \mathrm{KCl}, 10 \mathrm{mM}$ Hepes, $2 \mathrm{mM} \mathrm{MgCl} 2,5 \mathrm{mM}$ glucose and $0.1 \%(\mathrm{w} / \mathrm{v}$ ) bovine serum albumin (fatty acid free), and were finally resuspended in this buffer to a concentration of $5 \cdot 10^{5} \mathrm{cell} / \mathrm{s} /$. Mean mast cell count was about $8 \cdot 10^{5}$ cells per rat. Cytocentrifuge preparations stained with $0.1 \%$ toluidine blue $(\mathrm{w} / \mathrm{v})$ revealed a highly homogenous mast cell population with a purity higher than $99 \%$. Additional staining with May-Grünwald-Giemsa showed that platelets and erythrocytes were absent and that only a single mononucleated cell was present on a mast cell count of $10^{5}$ cells. Mast cells were counted using a Coulter counter (model ZM, Coulter Electronics GmBH, Krefeld, FRG). 
FIRST STEP

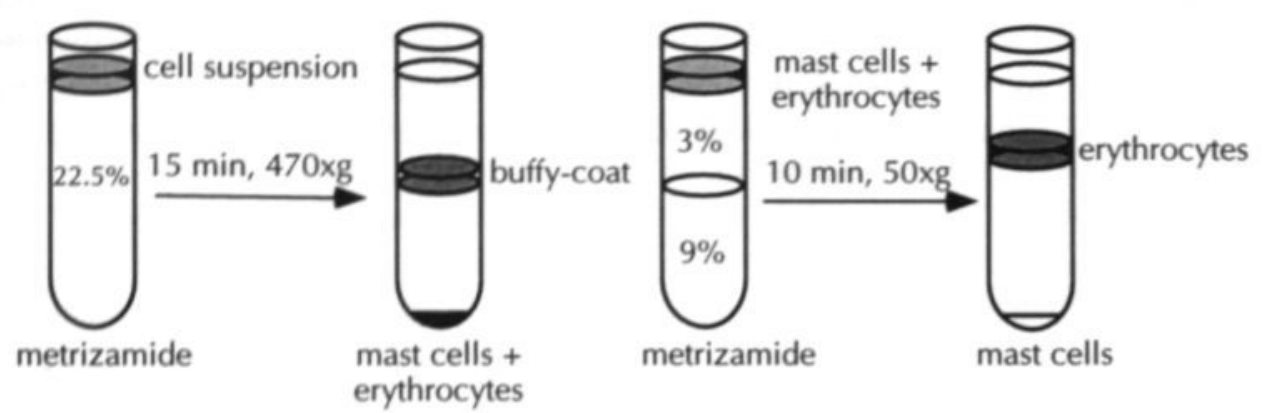

Figure 2.2: Two-step purification of peritoneal mast cells from a peritoneal lavage

\section{Activation of Peritoneal Mast Cells}

Aliquots $(100 \mu \mathrm{l})$ of the mast cell suspension $\left(10^{6} \mathrm{cells} / \mathrm{ml}\right)$ were brought into $900 \mu \mathrm{l}$ of buffer $\mathrm{pH}$ 7.4. After preincubation at $37{ }^{\circ} \mathrm{C}$ for $5 \mathrm{~min}$, cells were stimulated with compound $48 / 80(10 \mu \mathrm{g} / \mathrm{ml})$ in the presence of $1 \mathrm{mM} \mathrm{CaCl}_{2}(n=5)$. After $5 \mathrm{~min}, 500 \mu \mathrm{l}$ samples were withdrawn from the incubations, immediately layered onto $250 \mu \mathrm{l}$ of silicon oil ( $d=1.049)$ and centrifuged in an Eppendorf centrifuge for $20 \mathrm{~s}$ at $15,000 \times \mathrm{g}$. The supernatants were collected for the determination of histamine. Supernatants from unstimulated cells were also analyzed. Cells were incubated with $0.1 \%$ Triton X-100 $(\mathrm{v} / \mathrm{v})$ to determine the total mast cell histamine content. After addition of $500 \mathrm{ng}$ of the internal standard, samples were stored at $-20^{\circ} \mathrm{C}$ until analysis.

\subsection{RESULTS}

\section{Linearity, Stability, Reproducibility and Recovery}

The linearity of the fluorescence intensity versus the amounts of histamine and 3-methyl histamine was evaluated by analyzing a range from 0 to $700 \mathrm{ng}$ histamine and 3-methyl histamine per sample (corresponding to 0 to $14 \mathrm{ng}$ on column). Plots of relative peak areas of histamine and 3-methyl histamine versus the amounts derivatized were linear (Fig. 2.3). Regression equations of relative peak areas $(\mathrm{Y})$ versus the amounts (on column) of derivatized histamine and 3-methyl histamine $(X)$ were: $Y=0.090 X+0.056(r=$ $0.996)$ and $Y=0.116 X+0.031 \quad(r=0.999)$, respectively. Since the samples were individually concentrated, derivatized and analyzed, this implies that the procedure has a constant efficiency which is independent of the amount of histamine and 3-methyl histamine derivatized over the range selected. In practice, linearity was demonstrated up to $20 \mathrm{ng}$ on column for both histamine and 3-methyl histamine (data not shown). Assuming a signal to noise ratio of 3:1, lower detection-limits of histamine and 3-methyl histamine were about $20 \mathrm{pg}$ on column. Analysis of a standard solution containing 300 ng histamine and 3-methyl histamine in the presence of $250 \mathrm{ng}$ of the internal standard (see Materials and Methods) on day 7 showed that only $10 \%$ of the fluorescence intensity was lost over a period of seven days. Absolute peak areas of histamine, 3- 
methyl histamine and the internal standard on day 7 (in \% of absolute peak areas on day 0) were $90.9 \pm 4.5 \%, 91.7 \pm 2.9 \%$ and $90.9 \pm 2.6 \%$, respectively.

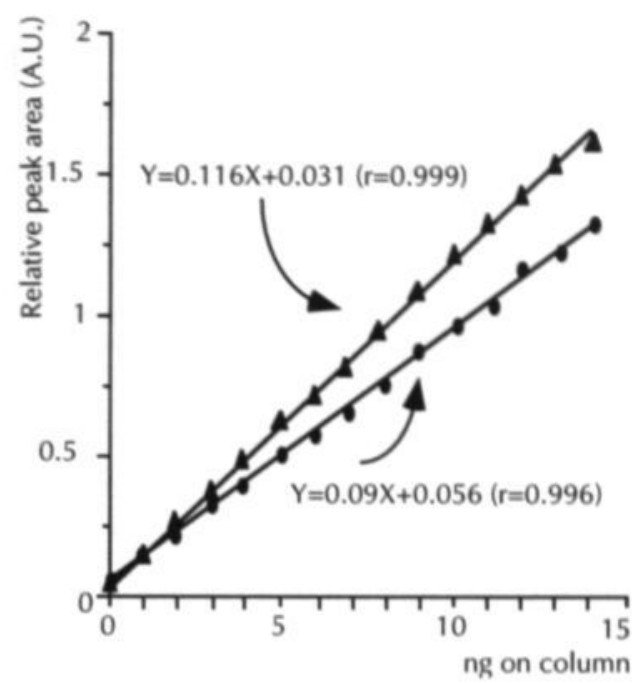

Figure 2.3: Calibration curves for histamine and 3-methyl histamine

X: ng histamine (0) or 3-methyl histamine (a) injected on column

Y: relative peak area (in arbitrary units, A.U.)

Derivatives of standard solutions used for the calibration curves were immediately analyzed upon derivatization and re-analyzed on day 1 and 7. Multiple analysis of variance revealed no significant differences between the relative peak areas of histamine and 3-methyl histamine on day 1, 2 and $7(\alpha=0.05)$ for all the amounts used. The low coefficient of variation both for samples containing low or high amounts of histamine or 3-methyl histamine (Table 2.1) shows that these compounds can be detected with a high reproducibility. When the samples were concentrated on the cation-exchange columns, absolute peak areas were always $>95 \%$ of those not concentrated on the columns, which implies that the recovery of the procedure was $>95 \%$.

\section{Applications}

The combination of purification of samples on cation-exchange columns followed by derivatization with fluorescamine was used to determine histamine and 3-methyl histamine in various biological samples. Fig. $2.4 \mathrm{~A}$ represents a typical chromatogram of a standard solution containing $5 \mathrm{ng}$ (on column) of histamine, 3-methyl histamine and the internal standard, showing that histamine elutes at $15 \mathrm{~min}$, 3-methyl histamine at 20 $\mathrm{min}$ and the internal standard at $25 \mathrm{~min}$. The three compounds were completely separated. 
Table 2.1: Reproducibility Data for the Determination of Histamine and 3-Methyl Histamine in Standard Solutions

\begin{tabular}{|c|c|c|c|c|}
\hline \multirow[b]{3}{*}{$\begin{array}{l}\text { Concentration } \\
\text { (ng/sample) }\end{array}$} & \multicolumn{4}{|c|}{ CV $\left.(\%)^{*}\right)$} \\
\hline & \multicolumn{2}{|c|}{ Within Day ${ }^{* *}$ ) } & \multicolumn{2}{|c|}{ Day to Day ${ }^{* * *}$ ) } \\
\hline & Histamine & $\begin{array}{l}\text { 3-Methyl } \\
\text { Histamine }\end{array}$ & Histamine & $\begin{array}{l}\text { 3-Methyl } \\
\text { Histamine }\end{array}$ \\
\hline 150 & 3.2 & 3.3 & 2.9 & 2.7 \\
\hline 600 & 6.7 & 6.9 & 6.7 & 5.9 \\
\hline
\end{tabular}

Each sample ( $n=6$ for each concentration) was concentrated on the cation-exchange columns, derivatized with fluorescamine and analyzed by HPLC on three days in a one week period. Standard solutions were prepared as described in Materials and Methods.

*) The coefficient of variance (CV) was obtained by dividing the standard deviation by the mean

*) $n=6$

*.*) $n=3$

Fig. 2.4B represents a typical chromatogram of a coronary effluent collected during a 1 min period after a bolus injection with $50 \mu \mathrm{g}$ compound $48 / 80$. As a consequence of mast cell degranulation, a net release of $1550 \pm 150 \mathrm{ng}$ (mean $\pm \mathrm{SD}, n=3$ ) of histamine in this time interval was observed. No 3-methyl histamine could be detected in the coronary effluent. In coronary effluents of non-stimulated hearts both histamine and 3methyl histamine were undetectable. Fig. 2.4C shows a representative chromatogram of a rat heart homogenate. The presence of 3-methyl histamine in rat hearts could not be demonstrated. The mean amount of histamine in rat hearts was found to be $2.7 \pm$ $0.3 \mu \mathrm{g} / \mathrm{gram}$ wet weight (mean $\pm \mathrm{SD}, n=9)$. When rat heart homogenates $(n=3)$ were spiked with $500 \mathrm{ng} 3$-methyl histamine, we observed mean amounts of $480 \pm 20 \mathrm{ng}$, corresponding to $96 \%$ recovery of this compound. Stimulation of rat peritoneal mast cells with $10 \mu \mathrm{g} / \mathrm{ml}$ compound $48 / 80$ (Fig. 2.4D) in the presence of $1 \mathrm{mM} \mathrm{CaCl} 2$ resulted in the release of $19 \pm 2 \mu \mathrm{g}$ histamine/106 cells (mean $\pm \mathrm{SD}, n=5$ ). Total histamine content was found to be $25 \pm 3 \mu \mathrm{g} / 10^{6}$ cells $(n=5)$, implicating that about $75 \%$ of total mast cell histamine was released with this agonist. Spontaneous histamine release, i.e., histamine release in the absence of agonist, was low $(4 \pm 1 \%)$. The amount of 3-methyl histamine in supernatants from stimulated peritoneal mast cells remained below the detection limit (i.e., $<1 \mathrm{ng} / 10^{6}$ cells). Analysis of supernatants from stimulated peritoneal mast cells, rat heart homogenates and coronary effluents on day 1 and 7 resulted in identical values as those observed on day 0 (data not shown). 

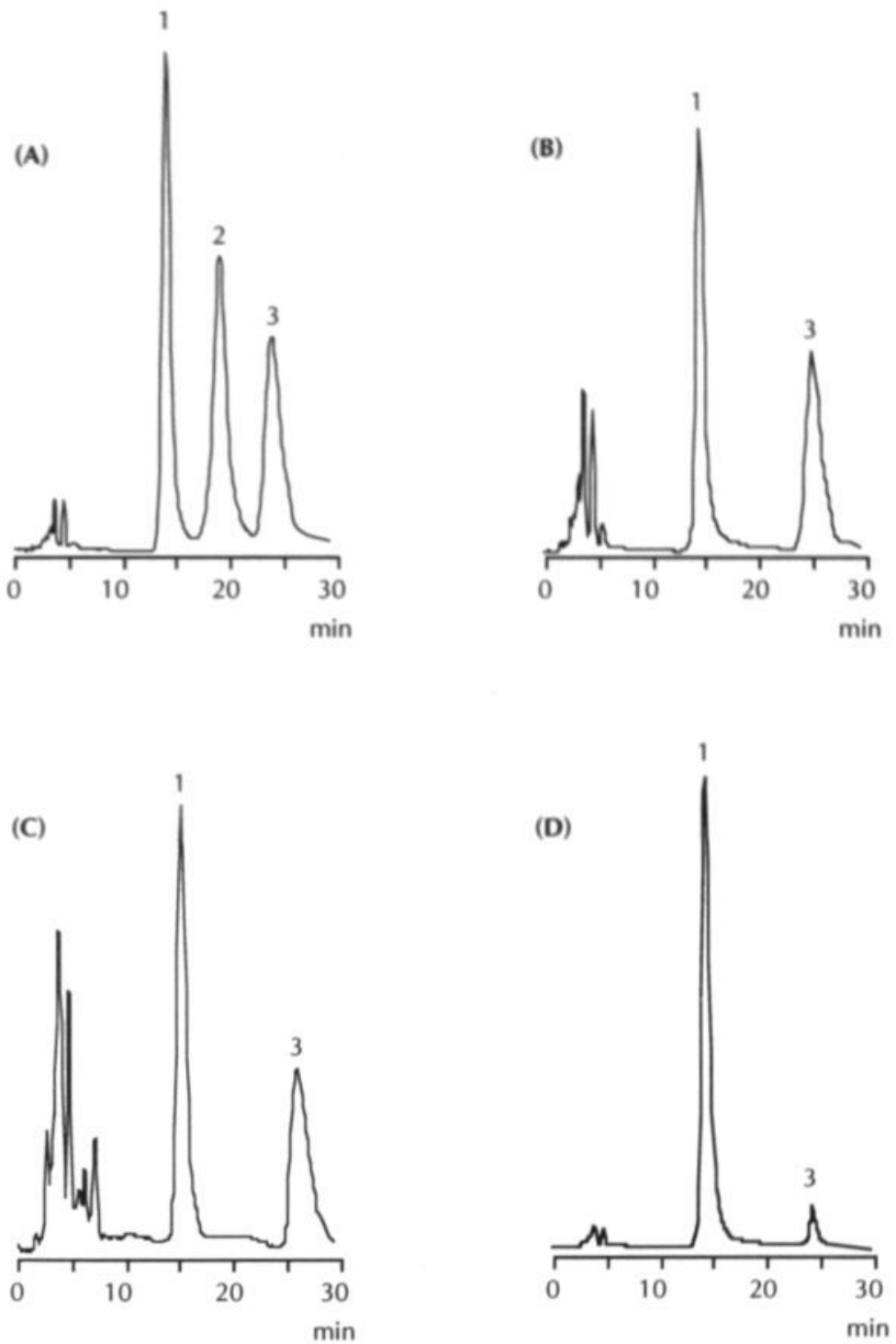

Figure 2.4: Typical reversed-phase chromatograms of standards and biological samples

(A) standard fluorescamine-derivatives of histamine (1), 3-methyl histamine (2) and the internal standard 1-methyl histamine (3), each peak representing $5 \mathrm{ng}$ on column

(B) coronary effluent from a heart stimulated with $50 \mu \mathrm{g}$ of the mast cell degranulating agent compound $48 / 80$

(C) an extract of a rat heart homogenate

(D) supernatant of rat peritoneal mast cells stimulated with $10 \mu \mathrm{g} / \mathrm{ml}$ compound $48 / 80$ in the presence of $1 \mathrm{mM} \mathrm{CaCl}_{2}$

The $Y$-axis represents fluorescence (arbitrary units), the $X$-axis the retention time (min). 


\subsection{DISCUSSION}

Most of the HPLC methods to determine histamine in biological samples described until now, make use of OPA as the derivatizing agent. Derivatization with this compound requires carefully controlled reaction conditions and duration of the derivatization reaction, and results in products which are relatively unstable $\left(\mathrm{t}_{1 / 2}\right.$ of about 3 hours, calculated from Saito et al. ${ }^{19}$ ). These properties require that the samples have to be analyzed immediately after derivatization or that derivatization takes place on- or post-column. The disadvantage of these procedures, where the mobile phase contains the OPA reagents, is that they require rather expensive additional equipments for the chromatographic system. In addition, the use of a post-column reagents results in significant peak broadening and dilution of the samples. ${ }^{19}$

In the present method, fluorescamine, frequently used in amino acid and peptide analysis, was used as the derivatizing agent. This compound, which in itself is not fluorescent, reacts only with primary amino groups of peptides almost instantaneously at room temperature in aqueous solution at $\mathrm{pH} 7.5$ to $9 .{ }^{12}$ The excess of fluorescamine is rapidly hydrolyzed ( $t_{1 / 2}$ is about 10 seconds) to yield a water-soluble non-fluorescent product. It was found that absolute peak areas of histamine, 3-methyl histamine and 1methyl histamine on day 7 were about $90 \%$ of those observed on day 0 . This indicates that derivatization of samples with fluorescamine resulted in relatively stable derivative. Since the decrease in absolute fluorescence was equal for all three compounds tested, samples may be analyzed up to 7 days after derivatization without a significant loss of sensitivity. This notion was confirmed by the observation that, for all the amounts investigated, relative peak areas of histamine and 3-methyl histamine on day 1 and 7 were identical to those of day 0 . Since the within-day as well as the day-to-day coefficients of variation were low, it can be concluded that the method has a good reproducibility. In addition, since absolute peak areas of samples, concentrated on cation-exchange columns, were always $>95 \%$ of the samples not concentrated on the columns, the method allowed a concentration procedure without a substantial loss of material.

The present technique was used to assess the histamine and 3-methyl histamine content of various biological samples. It was found that administration of compound $48 / 80$ to normoxic perfused isolated rat hearts resulted in a massive mast cell degranulation, as indicated by the release of about $60 \%$ of cardiac histamine in the first min after administration. Similar values have been found upon anaphylactic degranulation of sensitized rat hearts. ${ }^{22}$ Total histamine in rat hearts was found to be $2.7 \pm 0.4 \mu \mathrm{g} / \mathrm{g}$ wet weight, which is in agreement with results from Kasziba et al. ${ }^{10}$ Addition of compound $48 / 80(10 \mu \mathrm{g} / \mathrm{ml})$ and $\mathrm{CaCl}_{2}$ to rat peritoneal mast cells resulted in the release of $75 \%$ of total mast cell histamine, a value which has also been described earlier by others. ${ }^{7,14,23}$ The observation that the amounts of 3-methyl histamine in coronary effluents and cardiac tissue were below detection limits, show that under normal conditions, this metabolite is not present in cardiac tissue and that it is not released/formed after compound 48/80-induced mast cell degranulation. Similarly, it can be concluded that 3-methyl histamine is not constitutively present in 
peritoneal mast cells and is not released/formed upon compound 48/80-induced degranulation.

In conclusion, the described method allows the determination of histamine and 3methyl histamine in biological samples using a simple and highly sensitive isocratic HPLC method. It was found that derivatization with fluorescamine resulted in samples which were stable for at least 7 days. The present method has the advantage that all samples can be derivatized simultaneously and that analysis can be carried out in a simple, automated low-cost HPLC system. We propose that the present HPLC method provides a useful tool to determine histamine and 3-methyl histamine in biological samples.

\subsection{REFERENCES}

1. Adam, H.M., Hardwick, H.T. and Spencer, K.E.V. (1975) A method of estimating histamine in plasma. Br J Pharmacol 12, 397-405.

2. Arakawa, Y. and Tachibana, S. (1986) A direct and sensitive determination of histamine in aciddeproteinized biological samples by High-Performance-Liquid Chromatography. Anal Biochem 158, 20-27.

3. Ashmore, S.P., Thomson, A.H. and Simpson, H. (1989) High-performance liquid chromatographic technique for the rapid determination of histamine in both the plasma and cellular components of blood. J Chromatogr 496, 435-440.

4. Brown, M.J., Ind, P.W., Barnes, P.J., Jenner, D.A. and Dollery, C.T. (1980) A sensitive and specific radiometric method for the measurement of plasma histamine in normal individuals. Anal Biochem 109, 142-146.

5. Bruce, C., Taylor, W.H. and Westwood, A. (1979) An improved radioenzymatic assay for histamine in human plasma, whole blood, urine and gastric juice. Ann Clin Biochem 16, 259-264.

6. Enerbăck, L. and Svensson, I. (1980) Isolation of rat peritoneal mast cells by centrifugation on density gradients of percoll. J Immunol Methods 39, 135-145.

7. Ennis, M., Barrow, S.E. and Blair, I.A. (1984) Prostaglandin and histamine release from stimulated peritoneal mast cells. Agents Actions 14, 397-400.

8. Flancbaum, L., Fitzpatrick, J.C. and Fisher, H. (1989) Improved survival from compound 48/80 induced lethal stress and inhibition of myocardial histamine and carnosine mobilization by lodoxamide. Circ Shock 27, 155-164.

9. Graham, H., Scarpellini, J.A.D., Hubka, B.P. and Lowry, O.H. (1968) Measurement of the normal range of free histamine in human blood plasma. Biochem Pharmacol 17, 2271-2280.

10. Kasziba, E., Flancbaum, L., Fitzpatrick, J.C., Schneiderman, J. and Fisher, H. (1988) Simultaneous determination of histidine-containing dipeptides, histamine, methyl histamine and histidine by high-performance liquid chromatography. J Chromatogr 432, 315-320.

11. Keyzer, J.J., Wolthers, B.G., Muskiet, F.A.J., Breukelman, H., Kauffman, H.F. and De Vries, K. (1984) Measurement of plasma histamine by stable isotope dilution gas chromatography-mass spectrometry: methodology and normal values. Anal Biochem 139, 474-481.

12. Lai, C.Y. (1977) Detection of peptides by fluorescence methods. Methods Enzymol 47, 236-243.

13. Langendorff, O. (1895) Untersuchungen am ueberlebenden Saugethierherzen. Arch Ges Physiol $61,291-332$.

14. Levi-Schaffer, F. and Shalit, M. (1989) Differential release of histamine and prostaglandin $\mathrm{D}_{2}$ in rat peritoneal mast cells activated with peptides. Int Arch Allergy Appl Immunol 90, 352-357.

15. Mita, H., Yasueda, H. and Shida, T. (1980) Simultaneous determination of histamine and N-methyl histamine in human plasma and urine by gas chromatography-mass spectrometry. J Chromatogr $221,1-7$.

16. Pearce, F.L. (1991) Biological effects of histamine: an overview. Agents Actions 33, 4-7.

17. Robert, J.C., Vatier, J., Phuoc, B.K.N. and Bonfils, S. (1983) Determination of histamine, methyl histamines and histamine-o-phthaldialdehyde complexes by two high-performance liquid chromatographic procedures. J Chromatogr 273, 275-287.

18. Rönnberg, A.L., Hansson, C. and Hảkanson, R. (1984) High-performance Liquid Chromatographic determination of histamine in hiological samples after derivatization with $O$ phthalaldehyde. Anal Biochem 139, 338-344.

19. Saito, K., Horie, M., Nose, N., Nakagomi, K. and Nakazawa, H. (1992) High-performance liquid chromatography of histamine and 1-methyl histamine with on-column fluorescence derivatization. J Chromatogr 595, 163-168. 
20. Schwartz, L.B., Austen, K.F. and Wasserman, S.I. (1979) Immunologic release of $\beta$ hexosaminidase and $\beta$-glucuronidase from purified rat serosal mast cells. J Immunol 123, 14451450.

21. Shore, P.A., Burkhalter, A. and Cohn, V.H. (1959) A method for the fluorometric assay of histamine in tissue. J Pharmacol Exp Ther 127, 182-186.

22. Vleeming, W., van Rooij, H.H., Wemer, J. and Porsius, A.J. (1991) Characterization and modulation of antigen-induced effects in isolated rat heart. I Cardiovasc Pharmacol 18, 556-565.

23. Wu, C.Y., Chen, C.F. and Chiang, C.F. (1993) Stimulation of inositol phosphate production and GTP-ase activity by compound $48 / 80$ in rat peritoneal mast cells. Biochem Biophys Res Commun 192, 204-213. 


\section{| CHAPTER 3}

\section{Formation of Prostanoids and Hydroxy Fatty Acids by Stimulated Rat Peritoneal Mast Cells: Role of the Dietary Fat Type}

Parts of this chapter have been published in:

Charles M.C.J. van Haaster, Wim Engels, Paul J.M.R. Lemmens, Gerard Hornstra and Ger J. Van der Vusse

Formation of prostanoids and hydroxy fatty acids by stimulated peritoneal mast cells: role of the dietary fat type in rat

Biochim. Biophys. Acta (1993) 1167:147-154 


\subsection{ABSTRACT}

In order to gain insight into the role of mast cell membrane fatty acid composition on the formation of prostanoids and hydroxy fatty acids, peritoneal mast cells were isolated from rats which were fed diets differing in their fatty acid composition: (i) mackerel oil (MO), abundant in (n-3) fatty acids, (ii) sunflowerseed oil (SO), rich in (n-6) fatty acids, particularly linoleic acid, and (iii) hydrogenated coconut oil (HCO), rich in saturated fatty acids. The introduction of ( $n-3)$ fatty acids in the diet resulted in the incorporation of timnodonic acid, 20:5(n-3), clupanodonic acid, 22:5(n-3), and cervonic acid, 22:6(n-3), in mast cell phospholipids. This was accompanied by a significant decrease in the contents of arachidonic acid, 20:4(n-6), and one of its elongation products, adrenic acid, 22:4(n-6). The arachidonic acid content was highest in mast cell phospholipids from the HCO-group. The high content of linoleic acid in the SO. diet resulted in an increased incorporation of this fatty acid in mast cell phospholipids. Upon activation of the cells with the calcium ionophore A23187, major products released were $P G D_{2}, P G E_{2}, H H T, 9-H O D E$ and 13-HODE. Minor products released from these cells were 6-keto-PGF $1 \alpha, P F_{2 \alpha}, T \times B_{2}, 15-H E T E$ and 11-HETE. In general, the formation of prostanoids and hydroxy fatty acids increased with the precursor fatty acid content in mast cell membranes. For instance, the low arachidonic acid content in mast cell phospholipids from the $\mathrm{MO}$-group was accompanied by a relatively low formation of $P G D_{2}$ and $P G E_{2}$. The high linoleic acid content in mast cell phospholipids from the SO-group was accompanied by a high release of 9-HODE and 13-HODE, cyclooxygenase and lipoxygenase products from linoleic acid, respectively. The results suggest that in mast cells, dietary fatty acids are able to modulate the formation of prostanoids and hydroxy fatty acids by changing the availability of precursor fatty acids. We propose that diet-induced changes in the production of prostanoids and hydroxy fatty acids may have important consequences in biological processes in which these mast cell-derived products are involved.

\subsection{INTRODUCTION}

Eicosanoids (cyclooxygenase and lipoxygenase products containing 20-carbon fatty acids) are important mediators of inflammation and allergy. ${ }^{1,7}$ In mast cells, activation of phospholipase $A_{2}\left(P L A_{2}\right)$ results in the release of arachidonic acid, 20:4(n-6), the major substrate for eicosanoid synthesis, from membrane phospholipids. Arachidonic acid may subsequently be metabolized by cyclooxygenase to form prostaglandins and thromboxanes (also called: prostanoids), and by lipoxygenase to form hydroxy fatty acids (HETEs). In addition, arachidonic acid may be converted by cyclooxygenase to form 12 hydroxyheptadecatrienoic acid ( $\mathrm{HHT}$ ). Activation of $\mathrm{PLA}_{2}$ also results in the liberation of linoleic acid, 18:2(n-6), which, in turn, may be metabolized by cyclooxygenase and lipoxygenase to form 9-hydroxyoctadecadienoic acid (9-HODE) and 13-hydroxyoctadecadienoic acid (13-HODE), respectively.

In various cell types, such as platelets, changes in the type of dietary fat have been shown to affect the fatty acid composition of membrane phospholipids. ${ }^{13}$ Since some 
of these fatty acids serve as precursor fatty acids for the synthesis of prostanoids and hydroxy fatty acids, diet-induced changes in phospholipid fatty acid composition play an important role in the amount and/or type of prostanoid or hydroxy fatty acid produced. Until now, it is unknown to which extent the formation of prostanoids and hydroxy fatty acids is related to the fatty acid composition of mast cell phospholipids. In order to study this, peritoneal mast cells were isolated from rats which had been fed diets differing in their fatty acid composition.

It was found that, in general, an increased availability of arachidonic acid or linoleic acid in mast cell phospholipids was accompanied by an increased formation of prostanoids and hydroxy fatty acids, such as $\mathrm{PGD}_{2}$ and $9-\mathrm{HODE}$, respectively. The results suggest that in mast cells, dietary fatty acids are able to modulate the formation of prostanoids and hydroxy fatty acids by changing the availability of the precursor fatty acids in membrane phospholipids.

\subsection{MATERIALS AND METHODS}

\section{Animals}

Wistar rats of 3 weeks old, weighing about $120 \mathrm{~g}$, were obtained from a specified pathogen-free colony of the Charles River Laboratory (Sulzfeld, FRG). All animals were kept in stainless steel cages (1 rat per cage) and had free access to food and water. Experiments were performed according to institutional guidelines.

\section{Diets}

Animals were randomly divided into 3 groups and were fed, ad libitum, adequate diets containing 50 energy $\%(\mathrm{en} \%)$ fat (Table 3.1$)$, but which differed in their fatty acid composition:

1. MO-diet: 45 en\% mackerel oil (GSO) (supplier: Norwegian Herring Oil and Meal Industries, Fijllingdalen, Norway), rich in long-chain (n-3) polyunsaturated fatty acids, 20:5(n-3) and 22:6(n-3) in particular, supplemented with 5 en $\%$ sunflowerseed oil (SO) to ensure an adequate supply of ( $n-6)$ essential fatty acids

2. SO-diet: 50 en $\%$ sunflowerseed oil, rich in (n-6) fatty acids, $18: 2(n-6)$ in particular

3. HCO-diet: 45 en $\%$ hydrogenated coconut oil ( $\mathrm{HCO}$ ), rich in saturated fatty acids, supplemented with 5 en $\%$ SO.

The SO and HCO-diets were freshly prepared once a week, the MO-diet at least 3 times a week. All diets were stored at $4{ }^{\circ} \mathrm{C}$. The fatty acid composition of the dietary oils is presented in Table 3.2. All oils contained the following antioxidants (in $\mathrm{mg} / \mathrm{kg}$ ): monotertbutyl hydroquinine (200), citric acid (200) and 1,2-dihydro-6-ethoxy-2,4,4trimethylquinoline (EMQ, 100). Moreover, the following antioxidants were added to the complete diets: EMQ (150), $\alpha$-tocopherol acetate (150) and $\mathrm{NaHSe}_{3}(0.38)$. 
Ingredients

Casein

Mineralsa)

Vitamin mix ${ }^{b}$ )

Cellulose

Sucrose

Mackerel oil (MO)

Sunflowerseed oil (SO)
Energy (g.4184 kJ-1)

Diet

\begin{tabular}{lll}
\multicolumn{3}{c}{ Diet } \\
\hline MO & SO & HCO
\end{tabular}

62.0

62.0

5.4

62.0

5.4

1.0

15.0

15.0

1.0

15.0

65.8

65.8

48.4

5.4

53.8
Energy \%

23

.

-

27

50

Hydrogenated coconut oil (HCO)

a) $\mathrm{g} .4184 \mathrm{~kJ}^{-1}: \mathrm{KCl} 0.350, \mathrm{MgHPO}_{4} .3 \mathrm{H}_{2} \mathrm{O} 0.956, \mathrm{KH}_{2} \mathrm{PO}_{4} 0.475, \mathrm{KHCO}_{3} 0.719, \mathrm{C}_{6} \mathrm{H}_{5} \mathrm{Na}_{3} \mathrm{O}+2 \mathrm{H}_{2} \mathrm{O} 0.711$, $\left.\mathrm{CaCO}_{3} 2.014, \mathrm{MnC}_{6} \mathrm{H}_{5} \mathrm{O} 70.0756, \mathrm{C}_{6} \mathrm{H}_{5} \mathrm{FeO}+5 \mathrm{H}_{2} \mathrm{O} 0.0439, \mathrm{Cu}_{2} \mathrm{C}_{6} \mathrm{H}_{6} \mathrm{O}_{8} 0.0036, \mathrm{Zn}_{3}\left(\mathrm{C}_{6} \mathrm{H}_{5} \mathrm{O}\right)_{7}\right)_{2}, 2 \mathrm{H}_{2} \mathrm{O}$ $0.0125, \mathrm{KIO}_{3} 0.00007$

b) $8.4184 \mathrm{~kJ}^{-1}$ : choline 0.250 , vitamin E 0.020 , calciumsilicate 0.05 , myoinositol 0.025 , vitamin $B_{12}$ 0.000005 , vitamin A 0.0077 , niacin 0.005, pantothenic acid 0.005, riboflavin 0.0015, thiamin 0.0015, vitamin $D 0.00125$, vitamin $K 0.000227$, vitamin $B_{6} 0.0005$, folic acid 0.00025 , biotin 0.00005 , made up to 1.00 with sucrose

\section{Chemicals}

Metrizamide ${ }^{\circledR}$ was purchased from Nyegaard \& Co. (Oslo, Norway). Heparin (Thromboliquine ${ }^{\circledR}$ ) was obtained from Organon Teknika (Boxtel, the Netherlands). Gelatin, LiChroprep C8 (40 $\mu \mathrm{m}$ particles), Lichroprep C18 (40 $\mathrm{m}$ particles), Kieselgel 60 (7-230 mesh) and other reagents (all analytical grade) were purchased from Merck (Darmstadt, FRG). Hexane, chloroform, methanol, dichloromethane, diethyl ether, acetonitrile, tetrahydrofuran and ethyl acetate (all HPLC-grade) were from Rathburn (Walkerburn, United Kingdom). Triethylamine (99\%) and methoxylamine hydrochloride were obtained from Janssen Chimica (Tilburg, the Netherlands). Alumina $\mathrm{N}$ grade super I was purchased from ICN Medicals (Amsterdam, the Netherlands). Panacylbromide ( $p$-(9-anthroyloxy)phenacylbromide) was from Molecular Probes Inc. (Eugene, USA). Water was purified with a milli-Q purification unit from Millipore (Bedford, USA).

\section{Mast cell Isolation and Activation}

Mast cells were obtained by peritoneal lavage as described in Chapter 2. After purification, these cells were resuspended in buffer $\mathrm{pH} 7.4$, consisting of $136 \mathrm{mM} \mathrm{NaCl}$, $2.7 \mathrm{mM} \mathrm{KCl}, 8.1 \mathrm{mM} \mathrm{Na} 2 \mathrm{HPO}_{4}, 1.5 \mathrm{mM} \mathrm{KH}_{2} \mathrm{PO}_{4}$ and $0.1 \%$ gelatin (w/v), to a final concentration $10^{6}$ cells $/ \mathrm{ml}$. The cells were activated with $10 \mu \mathrm{M}$ of the calcium ionophore $\mathrm{A} 23187$ at $37{ }^{\circ} \mathrm{C}$ in the presence of $2 \mathrm{mM} \mathrm{CaCl}_{2}$. After $20 \mathrm{~min}$, the mixture was cooled, centrifuged at $195 \times \mathrm{g}$ for $5 \mathrm{~min}\left(4^{\circ} \mathrm{C}\right)$ and supermatants were collected. To the supernatant, $1 \mathrm{ml}$ of methanol was added and samples were stored at $-80^{\circ} \mathrm{C}$ until analysis. 
Table 3.2: $\quad$ Fatty Acid Composition of the Dietary Oils (\% of total Fatty Acids)

\begin{tabular}{|c|c|c|c|}
\hline \multirow[t]{2}{*}{ Fatty Acid } & \multicolumn{3}{|c|}{ Diet } \\
\hline & $\mathrm{MO}^{\mathrm{b})}$ & so & $\mathrm{HCO}$ \\
\hline 8:0 & & & 3.6 \\
\hline 10:0 & & & 8.6 \\
\hline 12:0 & & & 38.9 \\
\hline $14: 0$ & 5.4 & & 17.5 \\
\hline $16: 0$ & 10.7 & 6.4 & 10.2 \\
\hline 18:0 & 2.3 & 4.5 & 12.2 \\
\hline 20:0 & 0.1 & 0.4 & 0.1 \\
\hline 22:0 & & 0.1 & \\
\hline $24: 0$ & & 0.2 & \\
\hline $16: 2(n-4)$ & 0.3 & & \\
\hline $16: 1(n-7)$ & 2.8 & 0.2 & \\
\hline $18: 1(n-7) /(n-9)$ & 14.3 & 15.3 & 1.5 \\
\hline $20: 1(n-9) /(n-11)$ & 9.9 & 0.3 & 0.1 \\
\hline $22: 1(n-9) /(n-11)$ & 15.2 & 0.8 & 0.1 \\
\hline $24: 1(n-9)$ & 0.4 & & \\
\hline $18: 2(n-6)$ & 8.4 & 70.8 & 7.1 \\
\hline $18: 3(n-6)$ & 0.3 & & \\
\hline $20: 2(n-6)$ & 0.3 & & \\
\hline $20: 3(n-6)$ & 0.1 & & \\
\hline $20: 4(n-6)+20: 3(n-3)$ & 0.3 & & \\
\hline $22: 4(n-6)$ & 0.6 & & \\
\hline $18: 3(n-3)$ & 1.2 & 0.3 & \\
\hline $18: 4(n-3)$ & 4.2 & & \\
\hline $20: 4(n-3)$ & 1.0 & & \\
\hline $20: 5(n-3)$ & 7.3 & & \\
\hline $22: 5(n-3)$ & 1.2 & & \\
\hline $22: 6(n-3)$ & 12.9 & & \\
\hline
\end{tabular}

a) Based on the fatty acid composition of the oils (MO: mackerel oil; SO: sunflowerseed oil and HCO: hydrogenated coconut oil) and corrected for the proportions of the oil in the diets (see Table 3.1)

b) Determined by the supplier of the oil: the Norwegian Herring Oil and Meal Industries (Dr. J. Opstvedt), Fijllingdalen, Norway.

When no data are given, the amounts were below detection limits.

Lipid Extraction and Fatty Acid Analysis

Purified peritoneal mast cells were resuspended in $1 \mathrm{ml}$ of buffer $\mathrm{pH} 7.4$ to a final concentration of $7 \cdot 10^{5}$ cells $/ \mathrm{ml}$. To this suspension, $1 \mathrm{ml}$ of methanol was added. To all organic solvents used the anti-oxidant 3,5-di-tert-butyl-4-hydroxytoluene (BHT, 0.005\% $\mathrm{w} / \mathrm{v}$ ) was added to prevent oxidation of the fatty acids. Mast cell phospholipid fatty acids were determined according to Roemen et al. ${ }^{16}$ Briefly, lipids were extracted according to Folch et al. ${ }^{6}$ Total phospholipids were isolated from other lipids by thin layer chromatography after pre-developing the plates with chloroform/methanol 1:1 (v/v). 
After application of the sample, plates were developed with chloroform/ methanol/acetic acid/water 10/10/1/1 (v/v) followed by petroleum ether/diethyl ether/acetic acid 120/25/1.5 (v/v). Phospholipids were visualized by spraying with a $0.01 \%$ rhodamine solution in methanol. Subsequently phospholipids were hydrolyzed and their fatty acids methylated using $14 \%$ borontrifluoride $\mathrm{BF}_{3}(\mathrm{w} / \mathrm{v})$ in methanol at $100{ }^{\circ} \mathrm{C}$ for one hour. The methyl ester mixtures were analyzed using a gaschromatograph (Perkin Elmer, Autosystem) fitted with a WCOT fused-silica capillary column coated with $0.12 \mu \mathrm{m}$ CP-Sil 5 CB $(50 \mathrm{~m} \times 0.25 \mathrm{~mm}$ I.D., Chrompack International, Middelburg, the Netherlands). The temperature of the injector and the flame-ionization detector were set at $300{ }^{\circ} \mathrm{C}$. The starting temperature of the column was $160^{\circ} \mathrm{C}$. Thereafter, temperature of the column consecutively increased by $3^{\circ} \mathrm{C} / \mathrm{min}$ to $229^{\circ} \mathrm{C}$, by $2{ }^{\circ} \mathrm{C} / \mathrm{min}$ to $275^{\circ} \mathrm{C}$ and by $5^{\circ} \mathrm{C}$ to $290^{\circ} \mathrm{C}$. Routinely, $2 \mu \mathrm{l}$ of the methyl ester mixture was injected. Using the split injection technique, 1/37 of this volume was applied to the column. Carrier gas was helium ( $140 \mathrm{kPa})$. Peak areas were determined with PE Nelson Turbochrom II. 1,2 dinonadecanoyl-sn-glycero-3-phosphocholine (PC 19:0) was added to the samples before lipid-extraction in order to calculate the quantitative amounts. Quantifying the amount of methyl esters was based on the ratio between the peak area 19:0 and the peak area of the fatty acid methyl esters in the samples multiplied by the amount of 19:0 present in the standard solution. Results are expressed as \% of total fatty acids.

\section{Determination of Prostanoids and Hydroxy Fatty Acids}

Prostanoids were determined according to Engels et al. ${ }^{5}$ Briefly, after addition of $\mathrm{PGF}_{1 \alpha}$ and $\mathrm{PGE}_{1}$ as internal standards, chloroform/methanol extraction and purification on silica columns, samples were methoximated with methoxylamine hydrochloride. After purification on $\mathrm{C} 8$ reversed-phase material and esterification with panacylbromide, the panacylesters were separated and analyzed by $\mathrm{C} 18$ reversed-phase high performance liquid chromatography (HPLC) with fluorometric detection. Hydroxy fatty acids and HHT were determined according to Claeys et al. ${ }^{4}$ by C18 reversed-phase HPLC with ultraviolet detection at $235 \mathrm{~nm}$. 15-hydroxy-11,13-eicosadienoic acid, prepared from 10,14 cis-eicosadienoic acid ${ }^{4}$ was used as internal standard to calculate the quantitative amounts. Results are expressed as pmol/106 cells per $20 \mathrm{~min}$.

\section{Statistical Analysis}

Data are mean values \pm SEM. Columns with different superscripts differ significantly from one another $(P \leq 0.05)$. Comparisons were made using an analysis of variance followed by Tukey's method to evaluate the effect of changes in the dietary fat type. ${ }^{20}$

\subsection{RESULTS}

\section{Rat Growth}

No differences in body weights and relative weight gains of rats on different diets were observed over the feeding period. Body weight (in gram, mean \pm SD) before the 
feeding period were: MO, $200 \pm 25$; SO, $205 \pm 20$ and $\mathrm{HCO}, 215 \pm 23$. At the end of the feeding period weights were: $\mathrm{MO}, 430 \pm 30 ; \mathrm{SO}, 435 \pm 27$ and $\mathrm{HCO}, 452 \pm 32$.

\section{Fatty Acid Composition of Mast Cell Phospholipids}

The total amount of mast cell phospholipid fatty acids attributed to $14.20 \pm 0.94,14.75$ \pm 0.75 and $14.67 \pm 0.97 \mu \mathrm{g} / 10^{6}$ cells in rats fed MO, SO or HCO, respectively. No significant differences were observed between the three dietary groups. The high amount of stearic acid, 18:0, in the saturated fat-diet (HCO) was accompanied by a significant increase of this fatty acid in mast cell phospholipids (Table 3.3).

Table 3.3: Mast cell Phospholipid Fatty Acid Composition (\% of total Fatty Acids)

\begin{tabular}{|c|c|c|c|c|c|c|c|}
\hline \multirow{3}{*}{$\begin{array}{l}\text { Fatty Acid } \\
14: 0\end{array}$} & \multicolumn{7}{|c|}{ Diet } \\
\hline & \multicolumn{2}{|r|}{$\mathrm{MO}$} & \multicolumn{3}{|c|}{ so } & \multicolumn{2}{|c|}{$\mathrm{HCO}$} \\
\hline & 1.0 & \pm 0.3 & 0.4 & \pm & 0.3 & 1.4 & \pm 0.2 \\
\hline $16: 0$ & 29.6 & $\pm 1.0^{\mathrm{a}}$ & 23.7 & \pm & $0.9^{b}$ & 21.7 & $\pm 1.0^{b}$ \\
\hline 18:0 & 20.6 & $\pm 0.8^{a}$ & 23.0 & \pm & $1.2^{\mathrm{a}}$ & 27.9 & $\pm 1.0^{\mathrm{b}}$ \\
\hline 20:0 & & & 0.8 & \pm & $0.4^{\mathrm{a}}$ & 1.3 & $\pm 0.3^{a}$ \\
\hline $22: 0$ & & & & & & 0.7 & \pm 0.3 \\
\hline $24: 0$ & & & & & & 0.6 & \pm 0.3 \\
\hline $18: 1(n-7)$ & 4.0 & $\pm 0.1^{\mathrm{a}}$ & 1.4 & \pm & $0.4^{b}$ & 1.9 & $\pm 0.3^{b}$ \\
\hline $18: 1(n-9)$ & 11.0 & \pm 0.2 & 12.1 & \pm & 0.9 & 9.1 & \pm 1.1 \\
\hline $24: 1(n-9)$ & 2.7 & \pm 0.4 & 2.6 & \pm & 0.4 & 2.0 & \pm 0.4 \\
\hline $18: 2(n-6)$ & 7.2 & $\pm 0.7^{a}$ & 10.1 & \pm & $0.6^{b}$ & 5.8 & $\pm 0.3^{\mathrm{a}}$ \\
\hline $20: 2(n-6)$ & & & 1.7 & \pm & $0.5^{\mathrm{a}}$ & 0.2 & $\pm 0.1^{b}$ \\
\hline $20: 4(n-6)$ & 8.8 & $\pm 0.3^{\mathrm{a}}$ & 14.9 & \pm & $1.0^{\mathrm{b}}$ & 19.5 & $\pm 1.1^{\mathrm{c}}$ \\
\hline $22: 4(n-6)$ & & & 6.6 & \pm & $0.5^{a}$ & 6.9 & $\pm 0.4^{\mathrm{a}}$ \\
\hline $22: 5(n-6)$ & & & & & & 0.3 & \pm 0.2 \\
\hline $24: 2(n-6)$ & & & 2.1 & \pm & $0.4^{\mathrm{a}}$ & & \\
\hline $20: 5(n-3)$ & 5.4 & $\pm 0.3^{a}$ & & & & & \\
\hline $22: 5(n-3)$ & 5.8 & $\pm 0.6^{a}$ & & & & & \\
\hline $22: 6(n-3)$ & 2.9 & $\pm 0.6^{a}$ & & & & & \\
\hline
\end{tabular}

Peritoneal mast cells were isolated from rats fed diets differing in their fatty acid composition. MO: mackerel oil, SO: sunflowerseed oil and HCO: hydrogenated coconut oil. Phospholipid fatty acid methyl esters ( $n=6$ per group) were prepared and analyzed as described in Materials and Methods. Values in rows with different superscripts differ significantly from each other $(P \leq 0.05)$.

Similarly, the high content of linoleic acid, 18:2(n-6), in the SO-diet resulted in an increased content of this fatty acid in mast cell phospholipids. However, this was not accompanied by an increased content of arachidonic acid, 20:4(n-6), in mast cell phospholipids. The high contents of timnodonic acid, 20:5(n-3), clupanodonic acid, 22:5(n-3), and cervonic acid, 22:6(n-3), in the MO-diet were reflected by the presence of relatively high amounts of these fatty acids in mast cell phospholipids. The presence of (n-3) fatty acids was associated with a significant decrease in the contents of arachidonic acid, 20:4(n-6), and adrenic acid, 22:4(n-6), one of its elongation products. 
The arachidonic acid content was highest in mast cell phospholipids from the HCOgroup (Table 3.3).

\section{Release of Prostanoids and Hydroxy Fatty Acids}

The results showed that, irrespective of the diet, major products released by A23187. stimulated rat peritoneal mast cells were $\mathrm{PGD}_{2}, \mathrm{PGE}_{2}, \mathrm{HHT}, 9-\mathrm{HODE}$ and 13-HODE (Table 3.4). Minor amounts of 6-keto-PGF $1 \alpha, \mathrm{PGF}_{2}, \mathrm{TxB}_{2}, 15$-HETE and 11-HETE were also released. Preliminary studies, in which the mast cell pellet was extracted with alcohol, showed amounts of prostanoids and hydroxy fatty acids which were about equal to the detection limits, indicating that these compounds, once produced, were rapidly released from the cells.

Table 3.4: Metabolites of Linoleic Acid (LA) and Arachidonic Acid (AA) produced by Activated Peritoneal Mast Cells from Rats fed different Diets

Compounds

\begin{tabular}{ccc}
\multicolumn{3}{c}{ Diet } \\
\hline MO & SO & HCO \\
\hline
\end{tabular}

AA-Metabolites

6-keto-PGF $1 \alpha$

$\mathrm{PGF}_{2 \alpha}$

$\mathrm{TxB}_{2}$

$\mathrm{PGD}_{2}$

$\mathrm{PGE}_{2}$

$\mathrm{HHT}$

15-HETE

11-HETE

$\begin{aligned} 1.7 & \pm 0.9 \\ 0.9 & \pm 0.6 \\ 2.3 & \pm 1.5 \\ 31.9 & \pm 8.5^{\mathrm{a}} \\ 5.7 & \pm 1.8^{\mathrm{a}} \\ 33.0 & \pm 5.0 \\ 5.1 & \pm 2.4 \\ 6.6 & \pm 2.9\end{aligned}$

$4.4 \pm 1.3$

$2.8 \pm 2.5$

$2.1 \pm 1.0$

$109.3 \pm 17.3^{b}$

$19.6 \pm 2.7^{b}$

$47.5 \pm 9.1$

$5.5 \pm 5.5$

$10.0 \pm 4.5$

$\begin{array}{rc}4.0 & \pm 1.0 \\ 4.6 & \pm 2.8 \\ 4.2 & \pm 2.9 \\ 136.9 & \pm 16.9 \mathrm{~b} \\ 25.4 & \pm 8.2^{\mathrm{b}} \\ 53.9 & \pm 6.9 \\ 8.4 & \pm 2.2 \\ 13.0 & \pm 3.6\end{array}$

$4.0 \pm 1.0$

$4.2 \pm 2.9$

$136.9 \pm 16.9^{b}$

$53.9 \pm 6.9$

$13.0 \pm 3.6$
$25.4 \pm 8.2^{\mathrm{b}}$

\section{LA-Metabolites}

\begin{tabular}{lllll}
$9-\mathrm{HODE}$ & $22.6 \pm 3.3^{\mathrm{a}}$ & $104.7 \pm 9.4^{\mathrm{b}}$ & $51.9 \pm 5.1^{\mathrm{c}}$ \\
$13-\mathrm{HODE}$ & $29.7 \pm 3.8^{\mathrm{a}}$ & $152.9 \pm 20.7^{\mathrm{b}}$ & $75.5 \pm 6.4^{\mathrm{c}}$ \\
\hline
\end{tabular}

Peritoneal mast cells were isolated from rats fed diets differing in their fatty acid composition. Mast cells ( $n=6$ per group) were incubated in the presence of $2 \mathrm{mM} \mathrm{CaCl} 2$ and were stimulated with $10 \mu \mathrm{M}$ calcium ionophore $\mathrm{A23187}$ at $37^{\circ} \mathrm{C}$ for $20 \mathrm{~min}$. The products were determined in the supernatants as described in Materials and Methods. Within each row, columns with different superscripts differ significantly from each other ( $P \leq 0.05)$. Results are expressed as pmol/106 cells per $20 \mathrm{~min}$. MO: mackerel oil, SO: sunflowerseed oil and HCO: hydrogenated coconut oil.

Upon activation, in the group with the highest linoleic acid content in mast cell phospholipids (SO-group), the formation of 9-HODE and 13-HODE, cyclooxygenase and lipoxygenase products from linoleic acid, respectively, were highest. The production of linoleic acid-derived 9-HODE and 13-HODE were lowest in mast cell phospholipids from the MO-group, although the lowest linoleic acid values were observed in mast cell phospholipids of the HCO-group. The relatively low arachidonic acid content in mast cell phospholipids from the MO-group was accompanied by a moderate release of $\mathrm{PGD}_{2}$ and $\mathrm{PGE}_{2}$ upon activation. When compared to this group, the higher content of arachidonic acid in the SO- and HCO-group was accompanied by an increased 
production of $\mathrm{PGD}_{2}$ and $\mathrm{PGE}_{2}$ upon activation. Although not statistically different, similar trends were observed for other cyclooxygenase products from arachidonic acid, such as 6-keto $\mathrm{PGF}_{1 \alpha}, \mathrm{PGF}_{2} \alpha, \mathrm{TxB}_{2}, \mathrm{HHT}$ and lipoxygenase products such as 11-HETE and 15-HETE. The production of 12-HEPE, a lipoxygenase product from timnodonic acid, could not be detected.

\subsection{DISCUSSION}

We studied the effects of diet-induced changes in mast cell phospholipid fatty acid composition on the release of prostanoids and hydroxy fatty acids. To this end, peritoneal mast cells, isolated from rats fed diets differing in their fatty acid composition, were stimulated with the calcium ionophore A23187. Timnodonic acid, 20:5(n-3), the precursor of the prostanoids of the 3-series, clupanodonic acid, 22:5(n-3), and cervonic acid, 22:6(n-3), which were present in considerable amounts in the MO-diet, were readily incorporated in mast cell phospholipids from the MO-group. This was accompanied by a significant decrease in ( $n-6)$ fatty acids, such as arachidonic acid, $20: 4(n-6)$, and one of its elongation products, $22: 4(n-6)$ in mast cell phospholipids. It was found that the presence of large amounts of saturated fatty acids in the diet (HCOgroup) resulted in the incorporation of high amounts of arachidonic acid in mast cell phospholipids. Similar effects have been found in rat platelets and cultured human umbilical vein endothelial cells. ${ }^{9,19}$ The increased arachidonic acid content is most probably due to the high dietary intake of saturated acids, which is known to stimulate $\Delta 6$-desaturase. ${ }^{2}$ It was also found that the high content of linoleic acid in the SO-diet resulted in an increased incorporation of this fatty acid in mast cell phospholipids. This was not accompanied by high levels of arachidonic acid, which is most probably due the fact that high contents of dietary linoleic acid result in inhibition of $\Delta 6$-desaturase (substrate-inhibition). ${ }^{12}$

In general, a linear relation was observed between the arachidonic acid (AA) content in mast cell phospholipids ( $\mathrm{PL}$ ) and the formation of prostanoids and hydroxy fatty acids by these cells (Fig. 3.1A). For instance, the formation of $\mathrm{PGD}_{2}$ and $\mathrm{PGE}_{2}$ was high when the arachidonic acid content in membrane phospholipids was high (HCOgroup), whereas the formation of these compounds was low when the arachidonic acid content was low (MO-group). Although not statistically significant, similar trends were observed for other cyclooxygenase and/or lipoxygenase products from arachidonic acid, such as $\mathrm{PGF}_{2}, \mathrm{HHT}$ and 11 - HETE. These results strongly suggest that in mast cells, the arachidonic acid content in membrane phospholipids is an important determinant in the production of prostanoids and hydroxy fatty acids derived from this fatty acid. Similar conclusions could be reached for the linoleic acid content in membrane phospholipids and the formation of 9-HODE and 13-HODE, cyclooxygenase and lipoxygenase products from linoleic acid ${ }^{17}$, respectively. It should be noted that in order to obtain a linear relation between the linoleic acid content in membrane phospholipids and the formation of these hydroxy fatty acids, it was assumed that (n-3) polyunsaturated fatty acids (PUFA) were about 3 times as effectively converted by cyclooxygenase and lipoxygenase enzyme systems as linoleic acid (LA). This is based on the well-known 
finding that the affinity of cyclooxygenase and lipoxygenase for linoleic acid is much lower than for (n-3) fatty acids. ${ }^{11}$
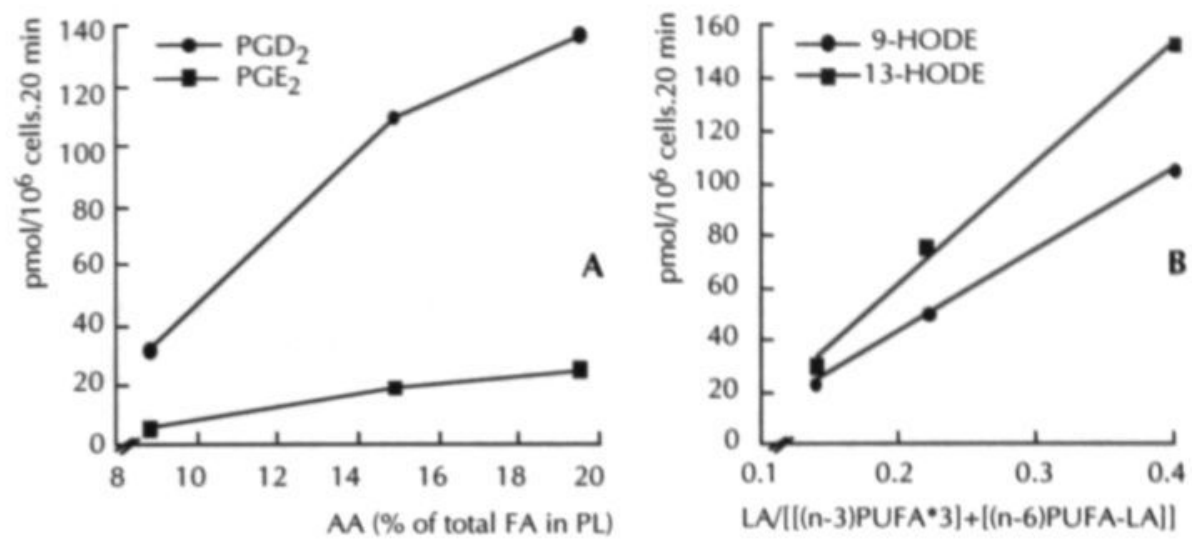

Figure 3.1: Formation of prostanoids and hydroxy fatty acids in mast cells: relation to availability of precursor fatty acids. AA: arachidonic acid; FA: fatty acid; PL: phospholipid; LA: linoleic acid; PUFA: polyunsaturated fatty acid

9-HODE and 13-HODE are formed by various cells such as endothelial cells ${ }^{3,8}$ and neutrophils..$^{4,8}$ Results from Henricks et al. ${ }^{10}$ indicate that $13-\mathrm{HODE}$, the predominant lipoxygenase product from linoleic acid in mast cells, may play a role in inflammatory reactions, because of its chemotactic activity on polymorphonuclear leukocytes. $\mathrm{PGD}_{2}$, the main cyclooxygenase product from arachidonic acid in mast cells, has been shown to potentiate histamine-induced increase of endothelial permeability. ${ }^{15,18}$ Therefore, it is tempting to speculate that diet-induced changes in the production of prostanoids and hydroxy fatty acids by mast cells, may ultimately have consequences for processes such as the inflammatory response, in which these mast cell-derived products are putatively involved.

\subsection{REFERENCES}

1. Borgeat, P. and Samuelsson, B. (1979) Arachidonic acid metabolism in polymorphonuclear leukocytes: unstable intermediate in formation of dihydroxy acids. Proc Natl Acad Sci USA 76, 3213-3217.

2. Brenner, R.R. and Peluffo, R.O. (1969) Regulation of unsaturated fatty acid biosynthesis. I. Effect of unsaturated fatty acids of 18 carbons on the microsomal desaturation of linoleic acid into $\gamma$ linolenic acid. Biochim Biophys Acta 176, 471-479.

3. Buchanan, M.R., Haas, T.A., Lagarde, M. and Guichardant, M. (1985) 13 . Hydroxyoctadecadienoic acid is the vessel wall chemorepellant factor, LOX. J Biol Chem 260, 16056-16059.

4. Claeys, M., Kivits, G.A.A., Christ-Hazelhof, E. and Nugteren, D.H. (1985) Metabolic profile of linoleic acid in porcine leukocytes through the lipoxygenase pathway. Biochim Biophys Acta 837, 35-51.

5. Engels, W., Kamps, M.A.F., Lemmens, P.J.M.R., Van der Vusse, G.J. and Reneman, R.S. (1988) Determination of prostaglandins and thromboxane in whole blood by high-performance liquid chromatography with fluorimetric detection. J Chromatogr 427, 209-218.

6. Folch, J., Lees, M. and Sloane-Stanley, G.H. (1957) A simple method for the isolation and purification of total lipids from animal tissues. J Biol Chem 226, 497-510. 
7. Ford-Hutchinson, A.W., Bray, M.A., Doig, M.V., Shipley, M.E. and Smith, M.J. (1980) Leukotriene $B_{4}$, a potent chemokinetic and aggregating substance released from polymorphonuclear leukocytes. Nature 286, 264-265.

8. Haas, T.A., Bastida, E., Nakamura, K., Hullin, F., Admirall, L. and Buchanan, M.R. (1988) Binding of 13-HODE and 5-, 12- and 15-HETE to endothelial cells and subsequent platelet, neutrophil and tumor cell adhesion. Biochim Biophys Acta 961, 153-159.

9. Heemskerk, J.W.M., Feijge, M.A.H., Kalafusz, R. and Hornstra, G. (1989) Influence of dietary fatty acids on membrane fluidity and activation of rat platelets. Biochim Biophys Acta 1004, 252260.

10. Henricks, P.A.J., Engels, F., Van der Vliet, H. and Nijkamp, F.P. (1991) 9- and 13-hydroxylinoleic acid possess chemotactic activity for bovine and human polymorphonuclear leukocytes. Prostaglandins 41, 21-31.

11. Holman, R.T. and Mohrhauer, H.A. (1963) A hypothesis involving competitive inhibitions in the metabolism of polyunsaturated fatty acids. Acta Chem Scand 17, 584-590.

12. Hornstra, G. (1982) Dietary fats, prostanoids and arterial thrombosis. In: Effect of type and amount of dietary fats on arterial thrombus formation Martinus Nijhoff Publishers, The Hague/Boston/London.

13. Hornstra, G. (1985) Dietary lipids, platelet function and arterial thrombosis in animals and man. Proc Nutr Soc 44, 371-378.

14. Linssen, M.C.J.G., Willemsen, P.H.M., Heijnen, V.V.T. and Van der Vusse, G.J. (1992) Arachidonic acid incorporation in cardiomyocytes, endothelial cells and fibroblast-like cells isolated from adult rat heart. Mol Cell Biochem 116, 203-209.

15. Metcalfe, D.D., Kaliner, M. and Donlon, M.A. (1981) The mast cell. CRC Crit Rev Immunol 3.

16. Roemen, T.H.M., Keizer, H. and Van der Vusse, G.J. (1990) Quantitative assessment of gammalinolenic acid in human blood and plasma with capillary gas chromatography. J Chromatogr 528, 447-452.

17. Schewe, T. and Kühn, H. (1991) Do 15-lipoxygenases have a common biological role? Trends Biochem Sci 16, 369-373.

18. Undem, B.J. and Weinreich, D. (1989) In: Neuroimmune networks: physiology and disease, (Goetzl, E.J. and Spector, N.H., eds.), pp. 155-162. New York: Alan Liss.

19. Vossen, R.C.R.M., van Dam-Mieras, M.C.E., Lemmens, P.J.M.R., Hornstra, G. and Zwaal, R.F.A. (1991) Membrane fatty acid composition and endothelial cell functional properties. Biochim Biophys Acta 1083, 243-251.

20. Wallenstein, S., Zucker, C.L. and Fleiss, J.L. (1980) Some statistical methods useful in circulation research. Circ Res 47, 1-9. 


\section{$\left.\right|_{\text {CHAPTER } 4}$}

Histamine Release by Compound 48/80Stimulated Rat Peritoneal Mast Cells: Role of the Dietary Fat Type 


\subsection{ABSTRACT}

Previously, it was found that the fatty acid composition of mast cell phospholipids and the formation of prostanoids and hydroxy fatty acids by these cells was significantly influenced by the dietary fatty acid composition. In the present study, we determined to which extent the degranulation process in mast cells was related to the fatty acid composition of membrane phospholipids. To this end, peritoneal mast cells were isolated from rats fed diets which differed in their fatty acid compositions: (i) genuine salmon oil (GSO), abundant in ( $n-3)$ fatty acids, (ii) sunflowerseed oil (SO), rich in (n-6) fatty acids, particularly linoleic acid, and (iii) hydrogenated coconut oil (HCO), rich in saturated fatty acids. Mast cells were stimulated with varying concentrations of the mast cell-degranulating agent compound $48 / 80$. The extent of mast cell degranulation was quantified by determination of histamine in the supernatants. No differences in compound 48/80-induced histamine release between the three dietary groups for any of the concentrations of compound $48 / 80$ tested were found. This finding strongly suggests that the extent of mast cell degranulation is independent of the fatty acid composition of membrane phospholipids.

\subsection{INTRODUCTION}

Biomembranes are composed of proteins, cholesterol and a mixture of phospholipids. Fatty acids, as part of membrane phospholipids, may serve as substrates for the cyclooxygenase and/or lipoxygenase enzyme systems. It has been found that changes in the dietary fat type significantly influenced the fatty acid composition of mast cell phospholipids and the formation of prostanoids and hydroxy fatty acids (Chapter 3). In rat platelets, similar to mast cells, there is a strict relationship between the arachidonate level in membrane phospholipids and thromboxane $A_{2}$ formation. ${ }^{7}$ In addition, it has been shown that the sensitivity of platelets to agonists, such as thromboxane, is significantly influenced by the type of dietary fat, i.e., platelets from rats fed diets rich in linoleic acid (SO-diet), are more sensitive to the aggregating effect of a low dose of collagen as compared to platelets of other diets. ${ }^{5}$ Platelets from rats fed high amounts of saturated fatty acids (HCO-diet) have been described to show a decreased responsiveness in terms of $\mathrm{Ca}^{2+}$ signaling, secretion and aggregation with agonists such as the thromboxane $A_{2}$ analogue $\cup 46619$ and thrombin, when compared to platelets from rats fed other diets. ${ }^{4}$ In this process, the membrane cholesterol/phospholipid ratio plays a prominent role. ${ }^{4}$ Results in human platelets have suggested that incorporation of docosahexaenoic acid, 22:6(n-3) and, to a lesser degree, eicosapentaenoic acid, 20:5(n3) into platelet membranes suppress thromboxane $A_{2}$ receptor function and thromboxane-mediated responses. ${ }^{1,8}$ Similar conclusions have been reached by other authors using a different experimental approach. ${ }^{9}$ Thus, besides its influence on the formation of eicosanoids, changes in the dietary fat type may also influence specific cellular processes and functions.

We studied to which extent in mast cells the degranulation process was influenced by diet-induced changes in membrane fatty acid composition. Therefore, rats were fed 
diets comparable to those described in Chapter 3, i.e., genuine salmon oil (GSO), rich in (n-3) fatty acids, sunflowerseed oil (SO), rich in linoleic acid, 18:2(n-6), and hydrogenated coconut oil (HCO), rich in saturated fatty acids. Peritoneal mast cells were isolated and incubated with varying concentrations of the $\mathrm{G}$ protein-activating compound 48/80.

Although changes in the dietary fatty acid composition resulted in significant changes in the fatty acid composition of mast cell phospholipids, no significant differences in compound 48/80-induced histamine release were observed between the three dietary groups. The results strongly suggest that in mast cells, the extent of degranulation was independent of the fatty acid composition of membrane phospholipids.

\subsection{MATERIALS AND METHODS}

\section{Animals}

Adult Wistar rats were obtained from a specified pathogen-free colony of the Charles River Laboratory (Sulzfeld, FRG). All animals were kept in stainless steel cages (1 rat per cage) and had free access to food and water. Experiments were performed according to institutional guidelines.

\section{Diets}

Animals were randomly divided into 3 groups and were fed, ad libitum, adequate diets containing 50 energy $\%$ (en\%) fat (see Table 3.1), but which differed in their fatty acid compositions:

1. GSO-diet: 45 en\% mackerel oil (GSO) (supplier: Norwegian Herring Oil and Meal Industries, Fijllingdalen, Norway), rich in long-chain ( $\mathrm{n}-3$ ) polyunsaturated fatty acids, 20:5(n-3) and 22:6(n-3) in particular, supplemented with 5 en\% sunflowerseed oil (SO) to ensure an adequate supply of (n-6) essential fatty acids

2. SO-diet: 50 en $\%$ sunflowerseed oil, rich in (n-6) fatty acids, $18: 2(n-6)$ in particular

3. HCO-diet: 45 en $\%$ hydrogenated coconut oil (HCO), rich in saturated fatty acids, supplemented with 5 en $\%$ SO.

The relative fatty acid composition of the diets is presented in Table 4.1. The diets were freshly prepared once a week and were stored at $-20^{\circ} \mathrm{C}$. Other conditions were similar to those described in Chapter 3.

\section{Mast cell Activation}

Mast cells were obtained by peritoneal lavage as described in Chapter 2. After purification, mast cells were resuspended in buffer $\mathrm{pH} 7.4$, consisting of (in $\mathrm{mM}$ ): $\mathrm{NaCl}$ (136), $\mathrm{KCl}(2.7)$, Hepes (10), glucose (5.0) and gelatin $(0.1 \%, w / v)$ to a final concentration of $10^{6} \mathrm{cells} / \mathrm{ml}$. One rat was used for each experiment. Samples of $125 \mu \mathrm{l}$ were brought into $875 \mu \mathrm{l}$ of buffer $\mathrm{pH} 7.4$ and were preincubated at $37{ }^{\circ} \mathrm{C}$ for $5 \mathrm{~min}$. Mast cell 
degranulation was evoked by addition of varying concentrations of compound 48/80 (final concentrations $0,0.1,0.75,1.5,3,5$ and $10 \mu \mathrm{g} / \mathrm{ml}$ ). Incubations were carried out in the presence of $1 \mathrm{mM} \mathrm{CaCl} 2$. Total releasable histamine was determined upon incubation of the cells with Triton X-100 $(0.1 \%$, w/v). After incubation for $5 \mathrm{~min}$ in the presence of compound 48/80,500 $\mu \mathrm{l}$ samples were withdrawn and immediately layered onto $250 \mu \mathrm{l}$ of silicon oil. After centrifugation at $15,000 \times \mathrm{g}$ for $20 \mathrm{~s}$, supernatants were collected and 1-methyl histamine was added as internal standard. Samples were stored at $-80^{\circ} \mathrm{C}$ until analysis.

Compound 48/80-induced histamine release was expressed as percentage of total mast cell histamine after correction for blank histamine release (i.e., histamine release in the absence of agonist), which was $<5 \%$ in all experiments.

Table 4.1 Fatty Acid Composition of the Diets (\% of Total Fatty Acids)

\begin{tabular}{|c|c|c|c|}
\hline \multirow[t]{2}{*}{ Fatty Acid } & \multicolumn{3}{|c|}{ Diet } \\
\hline & GSO & so & $\mathrm{HCO}$ \\
\hline $10: 0$ & 0.4 & & 5.0 \\
\hline $12: 0$ & & 0.1 & 42.7 \\
\hline $14: 0$ & 3.5 & 0.1 & 16.8 \\
\hline $15: 0$ & 0.4 & & \\
\hline $16: 0$ & 14.2 & 6.3 & 11.1 \\
\hline $17: 0$ & 0.2 & & \\
\hline 18:0 & 3.6 & 4.6 & 12.9 \\
\hline $20: 0$ & & 0.3 & 0.2 \\
\hline $22: 0$ & & 0.7 & 0.1 \\
\hline $24: 0$ & & 0.2 & 0.1 \\
\hline $16: 1(n-7)$ & 7.1 & 0.1 & \\
\hline $18: 1(n-7) \operatorname{tr}$ & 1.5 & & \\
\hline $18: 1(n-7)$ & 3.1 & 0.6 & 0.1 \\
\hline $18: 1(n-9)$ & 17.0 & 24.8 & 3.6 \\
\hline $18: 2(n-9)$ & & 0.4 & 0.1 \\
\hline $20: 1(n-9)$ & 4.8 & 0.2 & 0.1 \\
\hline $22: 1(n-9)$ & 1.0 & & \\
\hline $24: 1(n-9)$ & 0.5 & & \\
\hline $18: 2(n-6)$ & 9.8 & 60.9 & 7.1 \\
\hline $20: 2(n-6)$ & 0.7 & & \\
\hline $22: 4(n-6)$ & 0.7 & & \\
\hline $18: 3(n-3)$ & 1.4 & & \\
\hline $18: 4(n-3)$ & 2.0 & & \\
\hline $20: 5(n-3)$ & 10.5 & & \\
\hline $22: 5(n-3)$ & 4.4 & & \\
\hline $22: 6(n-3)$ & 9.3 & & \\
\hline
\end{tabular}

Methyl esters of dietary fatty acids were prepared and analyzed as described in Materials and Methods. Amounts are presented as \% of total fatty acids. GSO: genuine salmon oil; SO: sunflowerseed oil; HCO: hydrogenated coconut oil. 
Fatty Acid Composition of Mast Cell Phospholipids

After addition of the internal standard (consisting of $62 \mathrm{mg} \mathrm{PC} \mathrm{19:0} \mathrm{and} 100 \mathrm{mg}$ 3,5-ditert-butyl-4-hydroxytoluene (BHT) dissolved in $100 \mathrm{ml}$ of methanol), total lipid extraction was performed according to Bligh and Dyer. ${ }^{2}$ Aminopropyl bonded silica columns (500 mg) were used to separate phospholipids from the total lipid extract. ${ }^{6}$ Phospholipids were hydrolyzed and their fatty acids methylated using $14 \%$ borontrifluoride $\mathrm{BF}_{3}(\mathrm{w} / \mathrm{v})$ in methanol. Samples were incubated at $100{ }^{\circ} \mathrm{C}$ for one hour. Methyl ester mixtures were separated and quantified using a gaschromatograph (Perkin Elmer, Autosystem) fitted with a $50 \mathrm{~m}$ CP-Sil 88 polar capillary column with 0.25 $\mathrm{mm}$ I.D and $0.20 \mu \mathrm{m}$ film thickness (Chrompack, Middelburg, the Netherlands). Routinely, $2 \mu \mathrm{l}$ of the mixture was injected. Split ratio was 1:20. The temperature of the injector and the detector were set at $300{ }^{\circ} \mathrm{C}$. Starting temperature of the column was $160{ }^{\circ} \mathrm{C}$. After $10 \mathrm{~min}$, the temperature increased up to $190^{\circ} \mathrm{C}$ with a rate of $2.5^{\circ} \mathrm{C} / \mathrm{min}$ and finally after $20 \mathrm{~min}$ increased to $230{ }^{\circ} \mathrm{C}$ with a rate of $4{ }^{\circ} \mathrm{C} / \mathrm{min}$. This temperature was kept constant for another $10 \mathrm{~min}$. Carrier gas was helium (140 kPa). Peak areas were determined using the Turbochrom II integration system. A standard methyl ester mixture was used to identify the fatty acid methyl esters by means of the retention times. Quantification of the amount of methyl esters was based on the ratio between the peak area 19:0 and the peak area of the fatty acid methyl esters in the samples, multiplied by the amount of 19:0 present in the standard solution. Results are expressed as $\%$ of total fatty acids.

\section{Determination of Histamine}

Histamine was used to quantitate the extent of mast cell degranulation. This compound was determined in supernatants of stimulated cells by High-Performance Liquid Chromatography as described in Chapter 2.

\section{Statistical Analysis}

Data are presented as mean values \pm SEM. Columns with different superscripts differ significantly from each other ( $\mathrm{P} \leq 0.05)$. Comparisons were made using an analysis of variance followed by Tukey's method for multiple comparisons to evaluate the effect of changes in the dietary fat type. ${ }^{13}$

\subsection{RESULTS}

\section{Fatty Acid Composition Mast Cell Phospholipids}

In general, diet-induced changes in the fatty acid composition of mast cell phospholipids were comparable to those observed earlier (Chapter 3). For instance, the high content of ( $n-3)$ fatty acids in the fish-oil diet (GSO-group), resulted in an increased incorporation of timnodonic acid, 20:5(n-3), clupanodonic acid, 22:5(n-3), and cervonic acid, 22:6(n-3), in mast cell phospholipids (Table 4.2). The increased content of (n-3) fatty acids was accompanied by decreased contents of ( $n-6)$ fatty acids such as arachidonic acid, 20:4(n-6), and one of its elongation products, adrenic acid, 22:4(n-6). Again, the arachidonic acid content in mast cell phospholipids was highest in the HCO- 
group. When compared to the other two dietary groups, the high content of linoleic acid (LA), 18:2(n-6), in the SO-diet was accompanied by an increased content of this fatty acid and 22:2(n-6), a LA-elongation product, in mast cell phospholipids.

Table 4.2: Fatty Acid Composition of Mast Cell Phospholipids ( $\%$ of total Fatty Acids)

\begin{tabular}{|c|c|c|c|c|c|c|c|c|c|}
\hline \multirow{3}{*}{$\begin{array}{l}\text { Fatty Acid } \\
10: 0\end{array}$} & \multicolumn{9}{|c|}{ Diet } \\
\hline & \multicolumn{3}{|c|}{ GSO } & \multicolumn{3}{|c|}{ So } & \multicolumn{3}{|c|}{$\mathrm{HCO}$} \\
\hline & 2.5 & \pm & 0.1 & 1.9 & \pm & 0.2 & 1.6 & \pm & 0.4 \\
\hline $12: 0$ & 1.7 & \pm & $0.1^{a}$ & 1.4 & \pm & $0.1^{\mathrm{ab}}$ & 1.2 & \pm & $0.1^{b}$ \\
\hline $15: 0$ & 0.4 & \pm & 0.1 & 0.3 & \pm & 0.1 & 0.3 & \pm & 0.1 \\
\hline $16: 0$ & 24.3 & \pm & $0.2^{\mathrm{a}}$ & 21.7 & \pm & $0.5^{b}$ & 20.7 & \pm & $0.2^{b}$ \\
\hline $17: 0$ & 1.4 & \pm & $0.1^{\mathrm{a}}$ & 1.1 & \pm & $0.1^{b}$ & 0.9 & \pm & $0.1^{b}$ \\
\hline $18: 0$ & 23.2 & \pm & $0.6^{\mathrm{a}}$ & 26.4 & \pm & $0.4^{b}$ & 26.8 & \pm & $1.0^{\mathrm{b}}$ \\
\hline $20: 0$ & 1.3 & \pm & 0.1 & 1.2 & \pm & 0.2 & 1.8 & \pm & 0.1 \\
\hline 21:0 & 0.4 & \pm & 0.1 & 0.3 & \pm & 0.1 & 0.4 & \pm & 0.1 \\
\hline $22: 0$ & 0.4 & \pm & $0.1^{\mathrm{a}}$ & 0.5 & \pm & $0.1^{\mathrm{a}}$ & 1.2 & \pm & $0.1^{b}$ \\
\hline 23:0 & 0.5 & \pm & $0.2^{\mathrm{a}}$ & & & & & & \\
\hline $24: 0$ & 0.5 & \pm & $0.1^{\mathrm{a}}$ & 0.6 & \pm & $0.1^{\mathrm{a}}$ & 1.3 & \pm & $0.1^{b}$ \\
\hline $16: 1(n-7)$ tr & 0.9 & \pm & $0.1^{\mathrm{a}}$ & 0.8 & \pm & $0.1^{a b}$ & 0.5 & \pm & $0.1^{b}$ \\
\hline $16: 1(n-7)$ & 0.7 & \pm & $0.1^{\mathrm{a}}$ & 0.3 & \pm & $0.1^{b}$ & 0.4 & \pm & $0.1^{b}$ \\
\hline $18: 1(n-7)$ tr & 0.9 & \pm & 0.1 & 0.6 & \pm & 0.3 & 0.2 & \pm & 0.1 \\
\hline $18: 1(n-7)$ & 1.9 & \pm & $0.1^{a}$ & 0.9 & \pm & $0.1^{b}$ & 1.4 & \pm & $0.1^{\mathrm{c}}$ \\
\hline $18: 1(n-9)$ & 7.4 & \pm & 0.5 & 7.7 & \pm & 0.4 & 6.7 & \pm & 0.1 \\
\hline $20: 1(n-9) \operatorname{tr}$ & 0.4 & \pm & 0.1 & 0.7 & \pm & 0.5 & & & \\
\hline $20: 1(n-9)$ & 2.0 & \pm & $0.1^{\mathrm{a}}$ & 1.1 & \pm & $0.1^{b}$ & 0.8 & \pm & $0.1^{\mathrm{c}}$ \\
\hline $24: 1(n-9)$ & 4.8 & \pm & $0.3^{a}$ & 2.2 & \pm & $0.1^{\mathrm{b}}$ & 2.7 & \pm & $0.5^{b}$ \\
\hline $18: 2(n-6)$ & 5.1 & \pm & $0.3^{a}$ & 7.1 & \pm & $0.2^{\mathrm{b}}$ & 4.7 & \pm & $0.3^{\mathrm{a}}$ \\
\hline $20: 2(n-6)$ & 0.3 & \pm & $0.1^{\mathrm{a}}$ & 0.8 & \pm & $0.1^{b}$ & 0.4 & \pm & $0.1^{b}$ \\
\hline $20: 3(n-6)$ & 1.7 & \pm & 0.7 & 1.2 & \pm & 0.1 & 1.6 & \pm & 0.1 \\
\hline $20: 4(n-6)$ & 5.0 & \pm & $0.2^{\mathrm{a}}$ & 12.1 & \pm & $0.5^{b}$ & 15.0 & \pm & $0.5^{c}$ \\
\hline $22: 2(n-6)$ & 0.3 & \pm & $0.1^{\mathrm{a}}$ & 0.5 & \pm & $0.1^{b}$ & 0.2 & \pm & $0.1^{\mathrm{a}}$ \\
\hline $22: 4(n-6)$ & 0.6 & \pm & $0.1^{\mathrm{a}}$ & 4.3 & \pm & $0.6^{b}$ & 4.9 & \pm & $0.3^{b}$ \\
\hline $22: 5(n-6)$ & 0.4 & \pm & $0.1^{\mathrm{a}}$ & 0.5 & \pm & $0.1^{\mathrm{ab}}$ & 0.7 & \pm & $0.1^{b}$ \\
\hline $24: 2(n-6)$ & 0.3 & \pm & $0.1^{\mathrm{a}}$ & 1.3 & \pm & $0.1^{b}$ & 0.8 & \pm & $0.1^{\mathrm{c}}$ \\
\hline $18: 3(n-3)$ & 0.5 & \pm & 0.1 & 0.4 & \pm & 0.1 & 0.4 & \pm & 0.1 \\
\hline $20: 5(n-3)$ & 3.4 & \pm & $0.2^{\mathrm{a}}$ & 0.2 & \pm & $0.1^{b}$ & 0.2 & \pm & $0.1^{b}$ \\
\hline $22: 5(n-3)$ & 4.2 & \pm & $0.1^{\mathrm{a}}$ & 0.5 & \pm & $0.1^{b}$ & 0.6 & \pm & $0.1^{b}$ \\
\hline $22: 6(n-3)$ & 2.6 & \pm & $0.1^{\mathrm{a}}$ & 1.4 & \pm & $0.3^{b}$ & 1.2 & \pm & $0.1^{b}$ \\
\hline
\end{tabular}

Peritoneal mast cells were isolated from rats fed diets differing in their fatty acid composition. GSO: genuine salmon oil; SO: sunflowerseed oil; HCO: hydrogenated coconut oil. Methyl esters of mast cell phospholipid fatty acids were prepared and analyzed as described in Materials and Methods. Amounts, expressed as \% of total fatty acids, are presented as mean values \pm SEM (GSO and HCO, $n=4$ per group, SO, $n=5$ per group). Within each row, columns with different superscripts differ significantly from each other ( $P \leq 0.05)$. 


\section{Mast Cell Degranulation}

Mast cells were incubated with varying concentrations of compound $48 / 80$ in the presence of $1 \mathrm{mM} \mathrm{CaCl} 2$. At concentrations of compound $48 / 80$ of 0.1 or $0.25 \mu \mathrm{g} / \mathrm{ml}$, histamine release was negligible, i.e., $<5 \%$ of the total mast cell histamine content (Fig. 4.1). At a concentration of $0.5 \mu \mathrm{g} / \mathrm{ml}$, histamine release significantly increased, but no significant differences were observed between the three dietary groups (37 $\pm 3 \%, 43 \pm$ $3 \%$ and $36 \pm 5 \%$ in the GSO, HCO and SO-group, respectively). At a concentration of $1.5 \mu \mathrm{g} / \mathrm{ml}$, compound $48 / 80$-induced histamine release in the three groups was submaximal, reaching values of $64 \pm 3 \%, 67 \pm 4 \%$ and $69 \pm 5 \%$, respectively. Histamine release was about maximal at a concentration of $10 \mu \mathrm{g} / \mathrm{ml}$, reaching values of $73 \pm 4 \%$, $75 \pm 5 \%$ and $78 \pm 4 \%$, respectively. No additional increases in compound $48 / 80$ induced histamine release were observed at concentrations higher than $10 \mu \mathrm{g} / \mathrm{ml}$ (data not shown). No significant differences in histamine release were observed between the three dietary groups for any of the concentrations of compound 48/80 tested.

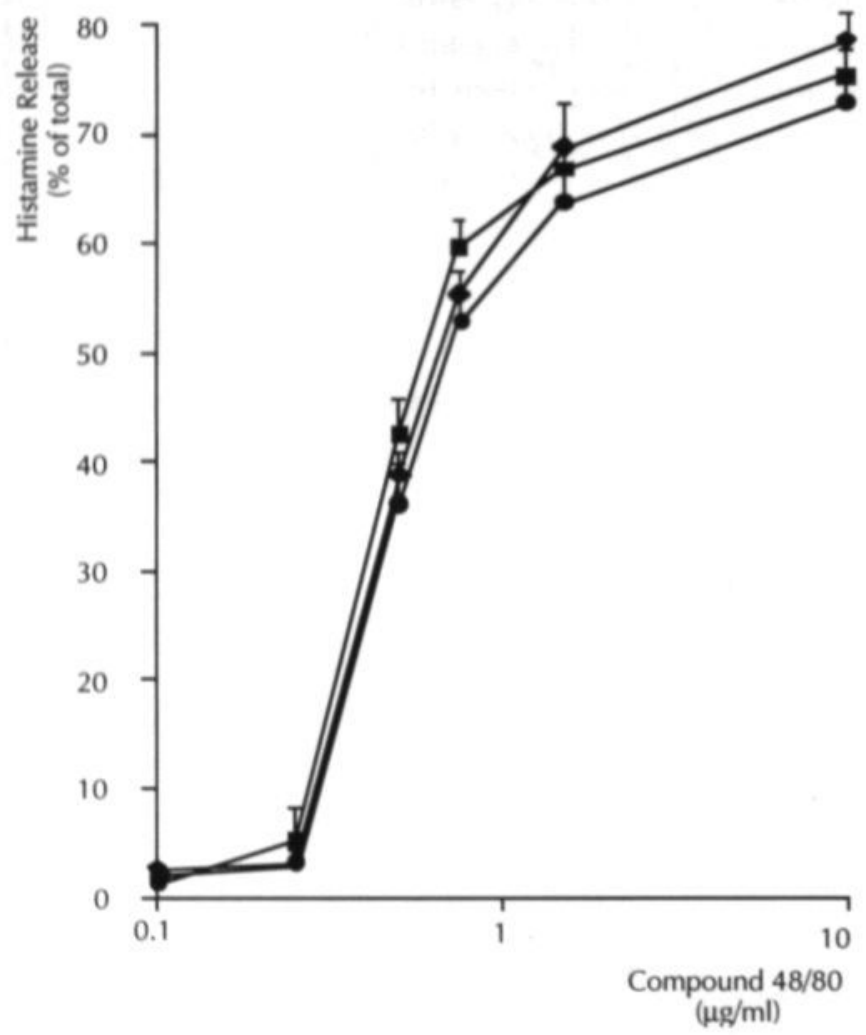

Figure 4.1: Compound 48/80-induced histamine release Mast cells, isolated from rats fed different diets, genuine salmon oil, GSO (•), hydrogenated coconut oil, HCO ( $\mathbf{m})$ or sunflowerseed oil, $S O(\bullet)$ were activated with various concentrations of the mast cell degranulating agent compound $48 / 80$ in the presence of $1 \mathrm{mM}$ $\mathrm{CaCl}_{2}$. Histamine release (mean values $\pm S E M, n=10$ ) is expressed as \% of total histamine content after correction for histamine release in the absence of agonist. 


\subsection{DISCUSSION}

Diet-induced changes in the fatty acid composition of mast cell phospholipids were comparable to those observed before (Chapter 3 ). For instance, the introduction (n-3) fatty acids in the diet (MO-group) resulted in an increased incorporation of timnodonic acid, 20:5(n-3), clupanodonic acid, 22:5(n-3), and cervonic acid, 22:6(n-3), in mast cell phospholipids. This was accompanied by a significant decrease in the contents of $(n-6)$ fatty acids, such as arachidonic acid (AA), 20:4(n-6), and one of its elongation products, adrenic acid, 22:4(n-6). In agreement with earlier results, it was found that the arachidonic acid content was highest in mast cell phospholipids in the HCO-group, a phenomenon which is most probably due to the stimulation of $\Delta 6$-desaturase by the high content of saturated fatty acids. ${ }^{3}$ Again, the content of linoleic acid, 18:2(n-6), in mast cell phospholipids was highest when the content of this fatty acid was high, i.e., in the SO-group. The results strengthen our earlier notion that the fatty acid composition of mast cell phospholipids is partially determined by the fatty acid composition of the diet.

Despite considerable changes in the fatty acid composition of mast cell phospholipids, no significant differences in compound $48 / 80$-induced histamine release were observed between the three dietary groups. These results indicate that the extent of mast cell degranulation is not related to the fatty acid composition of membrane phospholipids. Previously, we have shown that the formation of prostanoids and hydroxy fatty acids was closely related to the fatty acid composition of membrane phospholipids (Chapter 3). Therefore, the present results also indicate that the extent of mast cell degranulation is not related to the formation of prostanoids and hydroxy fatty acids. This will be discussed in detail in Chapter 5 .

Experiments with cultured human umbilical vein endothelial cells (HUVEC) have shown that the fatty acid composition of membrane phospholipids can extensively be modified by the addition of specific polyunsaturated fatty acids (PUFA). The decreased arachidonic acid content evoked by long-term incubation of HUVEC in the presence of (n-3) fatty acids was accompanied by a decreased formation of eicosanoids, such as 6keto-PGF $1 \alpha$ or $\mathrm{PGF}_{2 \alpha}$, when these cells were stimulated with thrombin. ${ }^{12}$ In addition, the sensitivity of isolated endothelial phospholipids to peroxidation has been found to be directly proportional to the number of double bonds present. ${ }^{11,12}$ In contrast, no effects of fatty acid modification in various membrane-related processes, such as the adherence of polymorphonuclear leukocytes and monocytes to the endothelial cell monolayer or the facilitation of fibrin-clot formation in recalcified human plasma (i.e., procoagulant activity) were observed..$^{10}$ It was concluded that, in general, the fatty acid composition of endothelial phospholipids could extensively be changed without influencing cellular function. Only in those reactions in which the fatty acids as such were involved, such as in the formation of eicosanoids and in lipid peroxidation, changes in the membrane fatty acid composition appeared to play an important role. Our findings in mast cells suggest that also in those cases in which fatty acids, as part of membrane phospholipids, mainly serve to create a suitable microenvironment for membrane-related processes, such as in the exocytotic process, diet-induced changes 
in membrane phospholipid fatty acid composition do not play an important role. Conversely, in those cases in which fatty acids actively participate in cellular processes, such as in the formation of prostanoids and hydroxy fatty acids, diet-induced changes in mast cell phospholipid fatty acid composition appears to play a prominent role.

In conclusion, despite considerable changes in mast cell phospholipid fatty acid composition, no significant differences in compound $48 / 80$-induced histamine release were observed between the three dietary groups. The results strongly suggest that the extent of mast degranulation is not related to the fatty acid composition of membrane phospholipids.

\subsection{REFERENCES}

1. Bayon, Y., Croset, M., Daveloose, D., Guerbette, F., Chirouze, V., Viret, J., Kader, J.C. and Lagarde, M. (1995) Effect of specific phospholipid molecular species incorporated in human platelet membranes on thromboxane $\mathrm{A}_{2}$ /prostaglandin $\mathrm{H}_{2}$ receptors. J Lipid Res 36, 47-56.

2. Bligh, E.G. and Dyer, W.J. (1959) A rapid method for total lipid extraction and purification. Can J Biochem Physiol 37, 911-917.

3. Brenner, R.R. and Peluffo, R.O. (1969) Regulation of unsaturated fatty acid biosynthesis. I. Effect of unsaturated fatty acids of 18 carbons on the microsomal desaturation of linoleic acid into $\gamma$ linolenic acid. Biochim Biophys Acta 176, 471-479.

4. Heemskerk, J.W.M., Feijge, M.A.H., Simonis, M.A.G. and Hornstra, G. (1995) Effects of dietary fatty acids on signal transduction and membrane cholesterol content in rat platelets. Biochim Biophys Acta 1255, 87-97.

5. Hornstra, G. (1982) Dietary fats, prostanoids and arterial thrombosis. In: Effect of type and amount of dietary fats on arterial thrombus formation Martinus Nijhoff Publishers, The Hague/Boston/London.

6. Kaluzny, M.A., Duncan, L.A., Merritt, M.V. and Epps, D.E. (1985) Rapid separation of lipid classes in high yield and purity using bonded phase columns. J Lipid Res 26, 135-140.

7. Lands, W.E.M. (1991) Biosynthesis of prostaglandins. Annu Rev Nutr 11, 41-60.

8. Parent, C.A., Lagarde, M., Venton, D.L. and Le Breton, G.C. (1992) Selective modulation of the human platelet thromboxane $A_{2}$ /prostaglandin $\mathrm{H}_{2}$ receptor by eicosapentaenoic and docosahexaenoic acids in intact platelets and solubilized platelet membranes. J Biol Chem 267, 6541-6547.

9. Scheurlen, M., Kirchner, M., Clemens, M.R. and Jaschonek, K. (1993) Fish oil preparations rich in docosahexaenoic acid modify platelet responsiveness to prostaglandin-endoperoxide/thromboxane $A_{2}$ receptor agonists. Biochem Pharmacol 46, 245-249.

10. Vossen, R.C.R.M. (1993) Fatty acid modification and endothelial cell reactivity. Maastricht: Thesis University of Limburg.

11. Vossen, R.C.R.M., Van Dam-Mieras, M.C.E., Hornstra, G. and Zwaal, R.F.A. (1993) Lipid peroxidation of phospholipid liposomes is influenced by their fatty acid composition. Am J Clin Nutr 57 (suppl.), 818-819.

12. Vossen, R.C.R.M., van Dam-Mieras, M.C.E., Lemmens, P.J.M.R., Hornstra, G. and Zwaal, R.F.A. (1991) Membrane fatty acid composition and endothelial cell functional properties. Biochim Biophys Acta 1083, 243-251.

13. Wallenstein, S., Zucker, C.L. and Fleiss, J.L. (1980) Some statistical methods useful in circulation research. Circ Res 47, 1-9. 


\section{|}

\section{Differential Release of Histamine and Prostaglandin $D_{2}$ in Rat Peritoneal Mast Cells: Roles of Cytosolic Calcium and Protein Tyrosine Kinases}

Parts of this chapter have been published in:

Charles M.C.J. van Haaster, Wim Engels, Paul J.M.R. Lemmens, Gerard Hornstra, Ger J. Van der Vusse and Johan W.M. Heemskerk

Differential release of histamine and prostaglandin $\mathrm{D}_{2}$ in rat peritoneal mast cells: roles of cytosolic calcium and protein tyrosine kinases

Biochim. Biophys. Acta (1995) 1265:79-88 



\subsection{ABSTRACT}

We studied how the release of histamine and prostaglandin $D_{2}\left(P G D_{2}\right)$ were related in rat peritoneal mast cells, and to which extent these processes were controlled by the cytosolic $\mathrm{Ca}^{2+}$ concentration, $\left[\mathrm{Ca}^{2+}\right]_{i}$, and protein tyrosine kinases. In the presence of $1 \mathrm{mM} \mathrm{CaCl}$, the $G$ protein-activating compound $48 / 80(10 \mu \mathrm{g} / \mathrm{ml})$ evoked a transient rise in $\left[\mathrm{Ca}^{2+}\right]_{i}$ and a relatively high secretion of histamine, but only a low release of $\mathrm{PGD}_{2}$. In contrast, $5 \mu \mathrm{M}$ thapsigargin (an inhibitor of endomembrane $\mathrm{Ca}^{2+}$. ATPases) or $5 \mu \mathrm{M}$ ionomycin (a $\mathrm{Ca}^{2+}$ ionophore) evoked high and prolonged rises in $\left[\mathrm{Ca}^{2+}\right]_{i}$, and stimulated the cells to release relatively small amounts of histamine and high amounts of $\mathrm{PGD}_{2}$. Stimulation of the cells with $\mathrm{CaCl}_{2}$ and $10 \mu \mathrm{M}$ ATP4- gave only minor quantities of histamine and $\mathrm{PGD}_{2}$, despite of the micromolar level of $\left[\mathrm{Ca}^{2+}\right]_{i}$ reached. When $\mathrm{CaCl}_{2}$ was replaced by EGTA, rises in $\left[\mathrm{Ca}^{2}+\right]_{i}$ as well as the release of histamine and $P G D_{2}$ were reduced with each agonist, but the preference of agonists to promote either the release of histamine or $P G D_{2}$ remained unchanged. In mast cells with depleted $\mathrm{Ca}^{2+}$ stores, the addition of $\mathrm{CaCl}_{2}$ stimulated the store-regulated $\mathrm{Ca}^{2+}$ entry resulting in prolonged rises in $\left[\mathrm{Ca}^{2+}\right]_{i}$. Simultaneous addition of compound $48 / 80$ and $\mathrm{CaCl}_{2}$ was required for release of histamine and $P G D_{2}$. In control cells with full $\mathrm{Ca}^{2+}$ stores, $P G D_{2}$ release evoked by compound $48 / 80$ was greatly reduced by genistein and methyl-2,5-dihydroxycinnamate, two structurally unrelated inhibitors of protein tyrosine kinases, whereas histamine secretion was not influenced by these inhibitors. Similarly, with thapsigargin or ionomycin as agonist, $P G D_{2}$ release was more sensitive to the tyrosine kinase inhibitors than histamine secretion. We conclude that in activated rat peritoneal mast cells: (i) the influx of extracellular $\mathrm{Ca}^{2+}$ amplifies agonist-evoked rises in $\left[\mathrm{Ca}^{2+}\right]_{i}$ as well as histamine secretion and $\mathrm{PGD}_{2}$ release; (ii) the amplitude of the $\left[\mathrm{Ca}^{2}{ }_{i}\right]_{i}$ rise does not determine the preferential effect of agonists to promote the release of histamine or $P G D_{2}$; (iii) the relatively high $P G D_{2}$ release evoked by thapsigargin and ionomycin is probably due to their potency to evoke a prolonged rise in $\left[\mathrm{Ca}^{2+}\right]_{i}$ and to activate protein tyrosine kinases.

\subsection{INTRODUCTION}

Mast cells play important roles in processes like inflammation, anaphylaxis and asthma. ${ }^{26}$ Activation of these cells results in the release of compounds like histamine and $\mathrm{PGD}_{2}$, which both induce vasodilation, increased vascular permeability and bronchoconstriction. ${ }^{11,18}$ Histamine and $\mathrm{PGD}_{2}$ are released from activated mast cells by two quite different mechanisms. Histamine is stored in intracellular secretory granules and is released into the extracellular medium by exocytosis. It is generally accepted that elevation in the cytosolic $\mathrm{Ca}^{2+}$ concentration $\left(\left[\mathrm{Ca}^{2+}\right]_{i}\right)$ as well as activation of the protein kinase $\mathrm{C}$ pathway are important in triggering the exocytotic event. ${ }^{13,34}$ The heterotrimeric $\mathrm{G}$ protein, $\mathrm{G}_{\mathrm{i} 3}$, probably plays an additional role in this process. ${ }^{3}$ On the other hand, the principle route to produce $\mathrm{PGD}_{2}$, is by activation of phospholipase $A_{2}, \mathrm{Ca}^{2+}$-dependent enzyme which releases arachidonic acid from membrane phospholipids. ${ }^{6,47}$ 
Data from a previous study (Chapter 4 ) have indicated that the extent of mast cell degranulation was not related to the formation of prostanoids and hydroxy fatty acids. This is in agreement with results of others who have shown that the release of histamine and $\mathrm{PGD}_{2}$ occur independently of each other and, hence, are regulated in different ways. For instance, it has been shown that stimulation of rat peritoneal mast cells with anti-immunoglobulin $\mathrm{E}$ or the $\mathrm{Ca}^{2+}$ ionophore $\mathrm{A} 23187$ resulted in a relatively high $\mathrm{PGD}_{2}$ release and a moderate histamine secretion $9,20,22$, whereas stimulation with bradykinin, substance $\mathrm{P}$ or compound $48 / 80$ resulted in a low $\mathrm{PGD}_{2}$ release and a high histamine secretion. 9,22 Comparable results have been obtained in human skin mast cells. ${ }^{4,5,8}$ In rat peritoneal mast cells, the release of histamine and $\mathrm{PGD}_{2}$ is known to be initiated after an increase of intracellular cytosolic $\mathrm{Ca}^{2+}$ concentration from basal (50$100 \mathrm{nM})$ to higher levels. ${ }^{20,25}$ Nevertheless, the time intervals in which these two release processes take place are often different. With various agonists, including compound $48 / 80$, histamine secretion is detectable already at seconds after the elevation of $\left[\mathrm{Ca}^{2+}\right]_{i}{ }^{25}$, whereas $\mathrm{PGD}_{2}$ generation starts much later. ${ }^{9,23}$ An exception appears to be the calcium ionophore A23187, which evokes a gradual and simultaneous release of both compounds that persists for several minutes. ${ }^{9,20}$ Taken together, this suggests that either release process requires different types of $\mathrm{Ca}^{2+}$ responses which, indeed, has been reported for mast cells stimulated with $\mathrm{A} 23187 .{ }^{20}$

We determined the relationship between histamine secretion and $\mathrm{PGD}_{2}$ release after stimulation of rat peritoneal mast cells with different types of agonists, and questioned to what extent these processes were related to the amplitude and shape of the agonist-evoked elevation in $\left[\mathrm{Ca}^{2+}\right]_{\mathrm{i}}$. To this end, mast cells were loaded with fura- 2 and the released products after stimulation with agonists that directly or indirectly influenced intracellular $\mathrm{Ca}^{2+}$ levels, were measured. Cells were stimulated in the presence of absence of $\mathrm{CaCl}_{2}$ with compound $48 / 80$, known to activate phospholipase $C$ in a $G$ protein-dependent way ${ }^{27,46}$ and with thapsigargin, an inhibitor of the endomembrane $\mathrm{Ca}^{2+}$-ATPases, which in many cell types activates the so-called 'storeregulated $\mathrm{Ca}^{2+}$ influx pathway' independently of phospholipase $\mathrm{C} .{ }^{36,39}$ Mast cells were also stimulated with agents directly permeating the plasma membrane for $\mathrm{Ca}^{2+}$, i.e., the $\mathrm{Ca}^{2+}{ }^{2}$-ionophore ionomycin, and the $\mathrm{Mg}^{2+}$-free form of ATP, ATP4-. The latter compound opens specific pores in the plasma membrane following binding to a specific purinergic receptor. ${ }^{33,42}$ Since in a variety of cell types protein tyrosine kinases are likely to be involved in the activation of phospholipase $A_{2}{ }^{19}$, arachidonic acid release $^{21,30}$ and eicosanoid formation ${ }^{12,29}$, we also questioned to which extent these kinases were involved in the differential release of histamine or $\mathrm{PGD}_{2}$. Two structurally dissimilar inhibitors of protein tyrosine kinases, genistein and methyl-2,5dihydroxycinnamate, which have been extensively tested in a number of cell types $1,29,40,44$, were used to answer this question.

Our results indicate that the store-regulated $\mathrm{Ca}^{2+}$ influx pathway represents a major contribution to the $\mathrm{Ca}^{2+}$ signal evoked by compound $48 / 80$ and thapsigargin, and that the influx of $\mathrm{Ca}^{2+}$ amplifies both histamine secretion and $\mathrm{PGD}_{2}$ release. However, we conclude that not the amplitude of the rise in $\left[\mathrm{Ca}^{2+}\right]_{i}$ but, instead, a different 
involvement of protein tyrosine kinases in these two release processes primarily determines the differential release of histamine and $P G D_{2}$.

\subsection{MATERIALS AND METHODS}

\section{Chemicals}

Metrizamide was purchased from Nyegaard (Oslo, Norway). Bovine serum albumin, compound 48/80 (a condensation product of $N$-methyl-p-methoxy-phenethylamine with formaldehyde), thapsigargin and $\mathrm{ATP}^{4-}$ (used in the $\mathrm{Mg}^{2+}$-free form) were obtained from Sigma (St. Louis, USA). Heparin (Thromboliquine ${ }^{\circledR}$ ) was from Organon Teknika (Boxtel, the Netherlands). Fura-2 acetoxymethyl ester and pluronic F-127 were from Molecular Probes (Eugene, USA) and ionomycin was from Serva (Heidelberg, FRG). All chemicals were of analytical grade and were predominantly obtained from Merck (Darmstadt, FRG). Water was purified with a milli-Q purification unit from Millipore (Bedford, USA). Methyl-2,5-dihydroxycinnamate and genistein were obtained from Sigma and were freshly dissolved into dimethyl sulfoxide before each experiment.

\section{Mast Cells}

Mast cells were isolated from retired breeder Wistar rats (Charles River Laboratories, Sulzfeld, FRG) according to the procedure described in Chapter 2. Five to ten rats were used for each experiment. Mast cells were finally resuspended in buffer $\mathrm{pH} 7.4$, consisting of $136 \mathrm{mM} \mathrm{NaCl}, 2.7 \mathrm{mM} \mathrm{KCl}, 10 \mathrm{mM}$ Hepes, $5 \mathrm{mM}$ glucose and $0.1 \%$ (w/v) bovine serum albumin (BSA) to a final concentration of $2 \cdot 10^{6}$ cells $/ \mathrm{ml}$. Mean mast cell number obtained per rat was about $8 \cdot 10^{5}$, which was sufficient to carry out 2 to 3 incubations.

\section{Measurements of Fura-2-fluorescence}

Suspended mast cells were loaded with fura- 2 acetoxymethyl ester $(3 \mu \mathrm{M})$ in the presence of the dispersing agent pluronic F-127 (1 mg/ml) under slow rotation at $20^{\circ} \mathrm{C}$ for $45 \mathrm{~min}$, as described earlier for rat platelets. ${ }^{16}$ In order to optimize the fura-2loading procedure, the incubation was carried out in buffer $\mathrm{pH} 7.4$ supplemented with $5 \%(w / v)$ BSA. After centrifugation at $195 \times \mathrm{g}$ for $5 \mathrm{~min}$, the fura-2-loaded cells were resuspended in buffer $\mathrm{pH} 7.4$ and brought into a cuvette to a final concentration of $10^{5}$ cells $/ \mathrm{ml}$. Changes in fura-2-fluorescence were measured at an emission wavelength of $500 \mathrm{~nm}$, while the excitation wavelength was switched continuously between 340 and $380 \mathrm{~nm}$. Fluorescence data were collected every $2 \mathrm{~s}$ and processed by a personal computer. Occasionally, divalent cation influx was measured by following the quenching of fura-2-fluorescence that occurred when externally added $\mathrm{Mn}^{2+}$ entered the cells. ${ }^{15}$ In this case, the excitation wavelength was fixed at $360 \mathrm{~nm}$. Calibration values for the calculation of $\left[\mathrm{Ca}^{2+}\right]_{i}$ were collected after the addition of $0.1 \%(\mathrm{w} / \mathrm{v})$ Triton X-100 or digitonin in the presence of $1 \mathrm{mM} \mathrm{CaCl}_{2}$, followed by $10 \mathrm{mM}$ EGTA and $50 \mathrm{mM}$ Tris/ $\mathrm{HCl}$ ( $\mathrm{pH} 8.3$ ), according to the procedure of Grynkiewicz et al. ${ }^{14}$ In all experiments, we checked for possible compartmentalization of the loaded fura-2: 
ATP4- $(10 \mu \mathrm{M})$ in the presence of $1 \mathrm{mM} \mathrm{CaCl} 2$ always evoked an immediate and high $\mathrm{Ca}^{2+}$ response, indicating that most of the dye was located in the cytosol.

\section{Mast Cell Activation}

Fura-2-loaded cells $\left(2.5 \cdot 10^{5}\right.$ cells $\left./ 2.5 \mathrm{ml}\right)$ were activated in plastic cuvettes at $37^{\circ} \mathrm{C}$ at a stirring rate of $150 \mathrm{rpm}$. Agonists were added from 1000-fold stock solutions. Calcium measurements were performed continuously or at time intervals indicated below. Samples of $500 \mu \mathrm{l}$ were withdrawn from the incubation mixture, immediately layered onto $200 \mu \mathrm{l}$ of silicon oil (d=1.049) and centrifuged in an Eppendorf centrifuge at $15,000 \times \mathrm{g}$ for $10 \mathrm{~s}$. The supernatants were collected for the determination of histamine or $\mathrm{PGD}_{2}$, and were stored at $-70{ }^{\circ} \mathrm{C}$ until analysis. Samples for analysis of $\mathrm{PGD}_{2}$ were methoximated directly after the experiment, according to the instructions of the kit. Total releasable histamine was measured by solubilization of a subsample of the cells with $0.1 \%(\mathrm{w} / \mathrm{v})$ Triton $\mathrm{X}-100$ and subsequent centrifugation of residual cell material at $15,000 \times g$ for $10 \mathrm{~s}$. The degrees of histamine secretion and $\mathrm{PGD}_{2}$ release were corrected for the amounts of histamine and $\mathrm{PGD}_{2}$ present in the supernatant of unstimulated cells, which values were constant within each experiment and attributed to $<7 \%$ of total releasable histamine and $<2 \mathrm{ng} \mathrm{PGD}_{2} / 10^{6}$ cells, respectively.

\section{Store-depleted Mast Cells}

For a subset of experiments, mast cells with depleted $\mathrm{Ca}^{2+}$ stores were prepared. To this end, the cells were loaded with fura- 2 as described above, except that ionomycin ( 5 $\mu \mathrm{M})$, thapsigargin $(100 \mathrm{nM})$ and EGTA $(0.2 \mathrm{mM})$ were added $15 \mathrm{~min}$ after the addition of the fura- 2 acetoxymethyl ester. These additions did not interfere with the uptake or deesterification of the fura-2 ester (data not shown) and resulted in a depletion of the intracellular $\mathrm{Ca}^{2+}$ store content of $85 \pm 5 \%$ and in a reduction of the releasable histamine content of $15 \pm 5 \%$ (mean $\pm S D, n=4$ ). After $30 \mathrm{~min}$ of incubation, the cells were centrifuged at $195 \times \mathrm{g}$ for $5 \mathrm{~min}$, washed twice with buffer $\mathrm{pH} 7.4$ and resuspended at a concentration of $10^{6} \mathrm{cells} / \mathrm{ml}$. The content of the internal $\mathrm{Ca}^{2+}$ stores was estimated from the maximal increase in $\left[\mathrm{Ca}^{2+}\right]_{i}$ evoked by ionomycin $(5 \mu \mathrm{M})$ in the presence of EGTA (1 mM). Because of the low dose of thapsigargin used during the store depletion procedure, mast cells still responded well to higher doses and to compound 48/80.

\section{Determination of $P G D_{2}$ and Histamine}

$\mathrm{PGD}_{2}$ was measured with an enzyme-linked immunoassay kit purchased from Cayman Chemical (Ann Arbor, USA). Histamine was determined by HPLC as described in Chapter 2. The lower detection limits were $0.3 \%$ of total releasable histamine and $1 \mathrm{ng}$ $\mathrm{PGD}_{2} / 10^{6}$ cells.

\section{Statistical Analysis}

To evaluate the effects of inhibitors, data were compared to those of control incubations, using an Analysis of Variance. P values $\leq 0.05$ were considered to be statistically significant. Data are presented as mean values \pm SEM. 


\subsection{RESULTS}

\section{Calcium Responses of Rat Peritoneal Mast Cells}

Fura-2-loaded mast cells were stimulated with non-lytic doses of various agonists in the presence of EGTA or $\mathrm{CaCl}_{2}$, and changes in $\left[\mathrm{Ca}^{2+}\right]_{i}$ were measured by spectrofluorometry. Calcium responses in the presence of $1 \mathrm{mM}$ EGTA were considered to reflect the release of $\mathrm{Ca}^{2+}$ from internal $\mathrm{Ca}^{2+}$ stores into the cytosol. Responses in the presence of $1 \mathrm{mM} \mathrm{CaCl}_{2}$ were considered to reflect internal $\mathrm{Ca}^{2+}$ mobilization in combination with influx of $\mathrm{Ca}^{2+}$ from the extracellular medium.

In the presence of EGTA, compound $48 / 80(10 \mu \mathrm{g} / \mathrm{ml})$ gave a rapid and transient increase in $\left[\mathrm{Ca}^{2+}\right]_{i}$ (Fig. 5.1A), probably caused by Ins $(1,4,5) \mathrm{P}_{3}$-evoked depletion of the intracellular $\mathrm{Ca}^{2+}$ stores. ${ }^{27,46}$ Stimulation with thapsigargin $(5 \mu \mathrm{M})$ resulted in a slow and prolonged rise in $\left[\mathrm{Ca}^{2+}\right]_{i}$ (Fig. 5.1B), pointing to gradual depletion of the $\mathrm{Ca}^{2+}$ stores by inhibition of the thapsigargin-sensitive $\mathrm{Ca}^{2+}$-ATPases in the store membranes. Incubation with ionomycin $(5 \mu \mathrm{M})$ resulted in an increase in $\left[\mathrm{Ca}^{2+}\right]_{i}$ which was transient in 4 out of 6 experiments (Fig. 5.1C) and was not reversed in the other two experiments. The $\mathrm{Mg}^{2+}$-free ATP4- $(10 \mu \mathrm{M})$ gave no significant $\mathrm{Ca}^{2+}$ response in the presence of EGTA (Fig. 5.1D), indicating that ATP4- at this concentration did not evoke store depletion.

In the presence of $\mathrm{CaCl}_{2}$, stimulation of the cells with compound $48 / 80$ resulted in a transient increase in $\left[\mathrm{Ca}^{2+}\right]_{i}$ with a similar shape but an amplitude which was almost ten-fold higher (Fig. 5.2A) when compared to stimulation in the absence of extracellular $\mathrm{Ca}^{2+}$ (Fig. 5.1A). Similarly, thapsigargin induced comparably shaped $\mathrm{Ca}^{2+}$ signals in the presence (Fig. 5.2B) and absence (Fig. 5.1B) of $\mathrm{CaCl}_{2}$, although the level of $\left[\mathrm{Ca}^{2+}\right]_{\mathrm{i}}$ reached was much higher when $\mathrm{CaCl}_{2}$ was present. Stimulation of the cells with ionomycin and $\mathrm{CaCl}_{2}$ resulted in a micromolar level of $\left[\mathrm{Ca}^{2+}\right]_{i}$ which remained high for at least 3 min. (Fig. 5.2C). ATP4- in combination with $\mathrm{CaCl}_{2}$ gave an immediate and high increase in $\left[\mathrm{Ca}^{2+}\right]_{i}$ (Fig. 5.2D), indicating that this agonist promoted the influx of $\mathrm{Ca}^{2+}$, despite its inability to evoke store depletion (Fig. 5.1D).

So far, the results suggest that depletion of the intracellular $\mathrm{Ca}^{2+}$ stores by compound $48 / 80$ and thapsigargin was accompanied by a considerable influx of $\mathrm{Ca}^{2+}$ from the extracellular medium. Additional support that these agonists opened divalent cation channels in the plasma membrane came from experiments in which we added $\mathrm{Mn}^{2+}$ to the incubations. In many cells, including mast cells, $\mathrm{Mn}^{2+}$ enters the cytosol through the same pathways as $\mathrm{Ca}^{2+}$, the appearance of which results in rapid quenching of fura-2-fluorescence. ${ }^{10}$ In these conditions, subsequent stimulation of the cells with compound $48 / 80$ and thapsigargin, resulted in two distinguishable decreases in fura-2fluorescence, indicating that both compounds caused $\mathrm{Ca}^{2+}$ influx (data not shown). Furthermore, the $\mathrm{Ca}^{2+}$ entry blocker $\mathrm{NiCl}_{2}(5 \mathrm{mM})$ appeared to inhibit the $\mathrm{CaCl}_{2-}$ dependent part of the $\mathrm{Ca}^{2}+$ responses evoked by both compound $48 / 80$ and thapsigargin (data not shown). 
Table 5.1: Effects of Various Agonists on $\left[\mathrm{Ca}^{2+}\right]_{i}$, Histamine Secretion and $P G D_{2}$ Release

\begin{tabular}{|c|c|c|c|c|c|c|c|}
\hline \multirow[t]{2}{*}{ Agonist } & \multirow[t]{2}{*}{ Addition } & \multicolumn{2}{|c|}{$\begin{array}{c}\text { Increase in }\left[\mathrm{Ca}^{2+}\right]_{i} \\
(\mathrm{nM})\end{array}$} & \multicolumn{2}{|c|}{$\begin{array}{c}\text { Histamine secretion } \\
(\% \text { of total) }\end{array}$} & \multicolumn{2}{|c|}{$\begin{array}{l}\mathrm{PGD}_{2} \text { release } \\
\text { (ng/106 cells) }\end{array}$} \\
\hline & & $2 \mathrm{~min}$ & $10 \mathrm{~min}$ & $2 \mathrm{~min}$ & $10 \mathrm{~min}$ & $2 \mathrm{~min}$ & $10 \mathrm{~min}$ \\
\hline \multirow[t]{2}{*}{ Compound $48 / 80$} & $\mathrm{CaCl}_{2}$ & $496 \pm 57$ & $275 \pm 37$ & $68 \pm 5$ & $72 \pm 5$ & $4 \pm 1$ & $7 \pm 1$ \\
\hline & EGTA & $30 \pm 2$ & $5 \pm 3$ & $17 \pm 4$ & $20 \pm 4$ & $<1$ & $<1$ \\
\hline \multirow[t]{2}{*}{ Thapsigargin } & $\mathrm{CaCl}_{2}$ & $460 \pm 140$ & $1156 \pm 314$ & $15 \pm 2$ & $18 \pm 2$ & $13 \pm 2$ & $15 \pm 2$ \\
\hline & EGTA & $71 \pm 20$ & $90 \pm 17$ & $5 \pm 1$ & $15 \pm 2$ & $9 \pm 2$ & $10 \pm 3$ \\
\hline \multirow[t]{2}{*}{ Iono:nycin } & $\mathrm{CaCl}_{2}$ & $691 \pm 215$ & $869 \pm 579$ & $9 \pm 3$ & $13 \pm 3$ & $22 \pm 3$ & $30 \pm 2$ \\
\hline & EGTA & $33 \pm 11$ & $29 \pm 7$ & $<0.3$ & $<0.3$ & $<1$ & $<1$ \\
\hline \multirow[t]{2}{*}{ ATP4- } & $\mathrm{CaCl}_{2}$ & $896 \pm 117$ & $1420 \pm 210$ & $5 \pm 1$ & $4 \pm 2$ & $<1$ & $<1$ \\
\hline & EGTA & $11 \pm 11$ & $12 \pm 12$ & $<0.3$ & $<0.3$ & $<1$ & $<1$ \\
\hline
\end{tabular}

Mast cells were stimulated with compound 48/80 (10 $\mu \mathrm{g} / \mathrm{ml})$, thapsigargin $(5 \mu \mathrm{M})$, ionomycin $(5 \mu \mathrm{M})$ or $\mathrm{ATP} 4-(10 \mu \mathrm{M})$ in the presence of $1 \mathrm{mM} \mathrm{CaCl} 2$ or $1 \mathrm{mM} \mathrm{EGTA}$, as indicated. Agonist-evoked increase in $\left[\mathrm{Ca}^{2+}\right]_{i}$, secretion of histamine $\left(\%\right.$ of total releasable histamine) and release of $P G D_{2}$ (ng released $/ 10^{6}$ cells) were determined at 2 and $10 \mathrm{~min}$ after the onset of activation. Detection limits were $0.3 \%$ for histamine secretion and 1 ng/106 cells for $P G D_{2}$ release. Data are mean values \pm SEM $(n=4)$. 


\section{Calcium Responses, Histamine Secretion and $\mathrm{PGD}_{2}$ Release}

Using fura-2-loaded mast cells, the rises in $\left[\mathrm{Ca}^{2+}\right]_{i}$ were compared to the potency of the agonists to release histamine and $\mathrm{PGD}_{2}$ under conditions where $\mathrm{Ca}^{2+}$ influx was present or absent (i.e., in the presence or absence of $\mathrm{CaCl}_{2}$ or EGTA, respectively). To this end, the cells were incubated at $37{ }^{\circ} \mathrm{C}$ and, at 2 and $10 \mathrm{~min}$ after the addition of agonists, $\left[\mathrm{Ca}^{2+}\right]_{i}$ was measured after which samples were taken from the incubation mixture for the determination of histamine and $\mathrm{PGD}_{2}$. The results are shown in Table 5.1. When extracellular $\mathrm{Ca}^{2+}$ was chelated with EGTA, stimulation with compound 48/80 (10 $\mu \mathrm{g} / \mathrm{ml})$ resulted in a relatively high histamine secretion $(20 \%$ of total releasable histamine after $10 \mathrm{~min}$ of activation), but in a low $\mathrm{PGD}_{2}$ release (below the detection limit of $1 \mathrm{ng} / 10^{6}$ cells). Stimulation with thapsigargin $(5 \mu \mathrm{M})$ and EGTA resulted in a somewhat lower histamine secretion ( $15 \%$ of total histamine), whereas the $\mathrm{PGD}_{2}$ release was relatively high ( $10 \mathrm{ng} / 10^{6}$ cells). In the presence of $\mathrm{CaCl}_{2}$, the release of both histamine and $\mathrm{PGD}_{2}$ appeared to be potentiated, when compared to the EGTAcontaining incubations. Compound $48 / 80$ with $\mathrm{CaCl}_{2}$, again, evoked a relatively high histamine secretion $\left(72 \%\right.$ of total mast cell histamine) and low $\mathrm{PGD}_{2}$ release $\left(7 \mathrm{ng} / 10^{6}\right.$ cells). Thapsigargin with $\mathrm{CaCl}_{2}$, again, was less efficient in evoking the release of histamine ( $18 \%$ of total) than of $\mathrm{PGD}_{2}\left(15 \mathrm{ng} / 10^{6}\right.$ cells). Apparently, with either agonist histamine secretion and eicosanoid formation were potentiated by the higher levels of $\left[\mathrm{Ca}^{2+}\right]_{i}$ reached by the entry of extracellular $\mathrm{Ca}^{2+}$. This conclusion was supported by the observation that the addition of $\mathrm{NiCl}_{2}$ significantly reduced the release of mast cell products induced by compound $48 / 80$ and $\mathrm{CaCl}_{2}$ (data not shown).

In the presence of EGTA, ionomycin $(5 \mu \mathrm{M})$ and ATP4- $(10 \mu \mathrm{M})$ were unable to evoke significant formation of histamine or $\mathrm{PGD}_{2}$. With $\mathrm{CaCl}_{2}$, however, ionomycin did promote the release of relatively low amounts of histamine $(13 \%$ of total releasable histamine) and high amounts of $\mathrm{PGD}_{2}\left(30 \mathrm{ng} / 10^{6}\right.$ cells). In contrast, ATP4- gave only a marginal secretion of histamine $\left(4 \%\right.$ of total) and no $\mathrm{PGD}_{2}$ release, despite the high, micromolar levels of $\left[\mathrm{Ca}^{2+}\right]_{i}$ reached in this condition.

Taken together, the results indicate that the G protein-activating compound $48 / 80$ was more efficient in evoking histamine secretion, whereas the $\mathrm{Ca}^{2+}$ mobilizers thapsigargin and ionomycin were more efficient in promoting the release of $\mathrm{PGD}_{2}$. ATP4- $(10 \mu \mathrm{M})$ was a rather ineffective inducer for either process. Since the rises in $\left[\mathrm{Ca}^{2+}\right]_{i}$ obtained with thapsigargin and ionomycin were more prolonged than the rises with compound $48 / 80$ (Table 5.1 and Fig. 5.2), it is tempting to suggest that the relatively high $\mathrm{PGD}_{2}$ release seen with the $\mathrm{Ca}^{2+}$ mobilizers is related to the prolonged high levels of $\left[\mathrm{Ca}^{2+}\right]_{i}$ (also see below). On the other hand, the results do not suggest that the amplitude or the shape of the $\left[\mathrm{Ca}^{2+}\right]_{i}$ signal determines the differential release of histamine or $\mathrm{PGD}_{2}$ since, in general, the preference of agonists to promote histamine or $\mathrm{PGD}_{2}$ release was the same in the presence or absence of extracellular $\mathrm{CaCl}_{2}$.

\section{$\mathrm{Ca}^{2+}$ Influx, Histamine Secretion and $\mathrm{PGD}_{2}$ Release by Store-depleted Mast Cells}

To further investigate the significance of $\mathrm{Ca}^{2+}$ influx for histamine secretion and $\mathrm{PGD}_{2}$ release, fura-2-loaded mast cells with depleted $\mathrm{Ca}^{2+}$ stores were prepared. Stimulation of the store-depleted cells with ionomycin in the presence of EGTA 


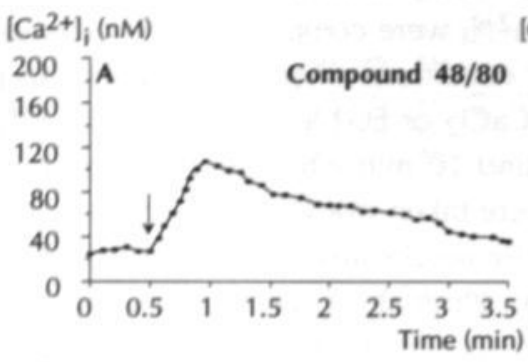

$\left[\mathrm{Ca}^{2+}\right]_{\mathrm{i}}(\mathrm{nM})$
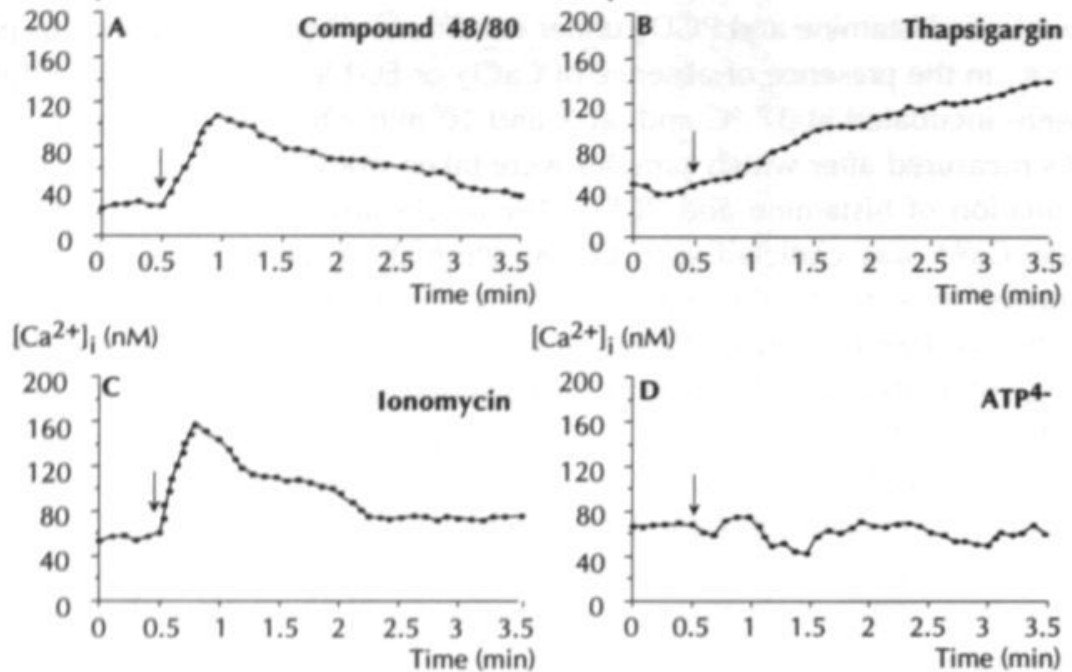

$\left[\mathrm{Ca}^{2+}\right]_{i}(\mathrm{nM})$

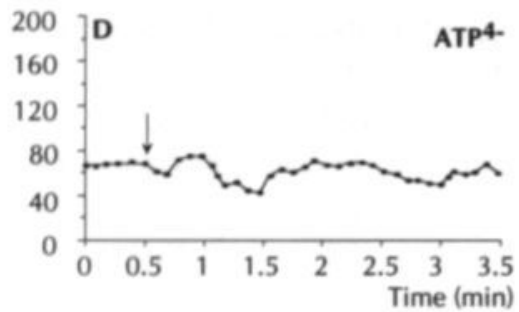

Figure 5.1: Calcium responses of mast cells in the presence of EGTA

Fura-2-loaded mast cells were stimulated with (A) compound 48/80 $(10 \mu \mathrm{g} / \mathrm{ml}),(B)$ thapsigargin $(5 \mu \mathrm{M}),(C)$ ionomycin $(5 \mu \mathrm{M})$ or (D) ATP4- $(10 \mu \mathrm{M})$ in the presence of $1 \mathrm{mM}$ EGTA. Tracings are shown of changes in $\left(\mathrm{Ca}^{2+}\right]_{i}$ representative for 6 experiments. Arrows indicate the addition of agonists.
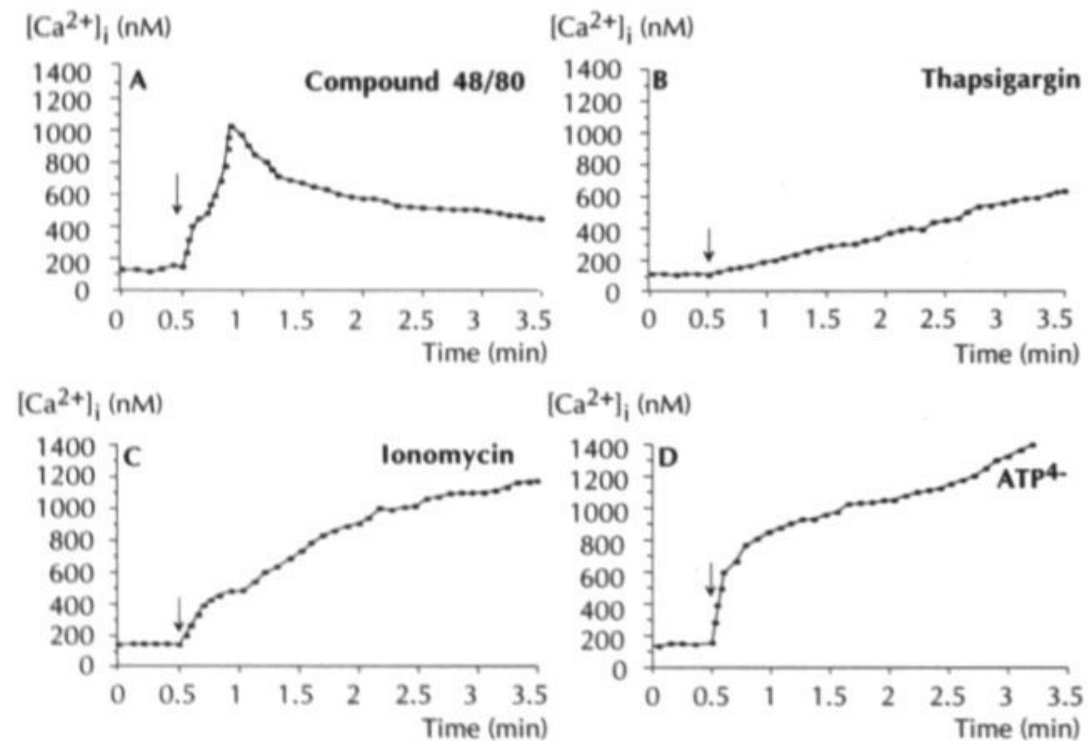

Figure 5.2: Calcium responses of mast cells in the presence of $\mathrm{CaCl}_{2}$

Fura-2-loaded mast cells were stimulated with (A) compound 48/80 $(10 \mu \mathrm{g} / \mathrm{ml}),(B)$ thapsigargin (5 $\mu \mathrm{M}),(C)$ ionomycin $(5 \mu \mathrm{M})$ or $(D)$ ATP4- $(10 \mu \mathrm{M})$ in the presence of $1 \mathrm{mM}$

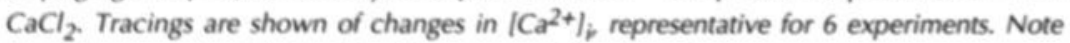
the different scale of the $Y$-axis when compared to Figure 5.1. 
resulted in a maximal increase in $\left[\mathrm{Ca}^{2+}\right]_{i}$ which was only $15 \pm 5 \%$ (mean values $\pm \mathrm{SEM}$, $n=3$ ) of the increase seen in untreated control cells, indicating that most of the intracellular $\mathrm{Ca}^{2+}$ was removed by the depletion procedure. Determination of the histamine content in the store-depleted cells learned that no more than $15 \pm 5 \%$ of the total releasable histamine was lost by the procedure.

When $1 \mathrm{mM} \mathrm{CaCl} 2$ was added to store-depleted mast cells, an immediate and prolonged increase in $\left[\mathrm{Ca}^{2+}\right]_{i}$ of about $300 \mathrm{nM}$ was observed (Table 5.2), most probably due to the influx of extracellular $\mathrm{Ca}^{2+}$ through the store-regulated entry pathway. In control cells (i.e., cells with full $\mathrm{Ca}^{2+}$ stores), the addition of $\mathrm{CaCl}_{2}$ resulted in a $\left[\mathrm{Ca}^{2+}\right]_{1}$ rise of only $10 \mathrm{nM}$. Despite the high $\mathrm{Ca}^{2+}$ response in the store-depleted cells, $\mathrm{CaCl}_{2}$ addition resulted in only a marginal release of histamine and $\mathrm{PGD}_{2}$. Apparently, the influx of $\mathrm{Ca}^{2+}$ and the resulting high levels of $\left[\mathrm{Ca}^{2+}\right]_{i}$ as such were insufficient to promote a substantial release of these compounds. When compound $48 / 80$ was added to the store-depleted cells, no $\mathrm{Ca}^{2+}$ signal was detected and neither histamine nor $\mathrm{PGD}_{2}$ were released (Table 5.2). However, when compound $48 / 80$ was added with $\mathrm{CaCl}_{2}$, a sustained increase in $\left[\mathrm{Ca}^{2+}\right]_{i}$ was accompanied by a high histamine secretion ( $56 \%$ of total releasable histamine) and high $\mathrm{PGD}_{2}$ release $\left(44 \mathrm{ng} / 10^{6}\right.$ cells).

Table 5.2: Rises in $\left.\mathrm{CCa}^{2+}\right]_{i}$, Histamine Secretion and $\mathrm{PGD}_{2}$ Release in Store-depleted Mast Cells

\begin{tabular}{|c|c|c|c|c|c|c|}
\hline \multirow[t]{2}{*}{ Addition } & \multicolumn{2}{|c|}{$\begin{array}{c}\text { Increase in }\left[\mathrm{Ca}^{2+}\right]_{\mathrm{i}} \\
(\mathrm{nM})\end{array}$} & \multicolumn{2}{|c|}{$\begin{array}{c}\text { Histamine secretion } \\
\text { (\% of total) }\end{array}$} & \multicolumn{2}{|c|}{$\begin{array}{l}P^{P G} D_{2} \text { release } \\
\text { (ng/106 cells) }\end{array}$} \\
\hline & $2 \mathrm{~min}$ & $10 \mathrm{~min}$ & $2 \mathrm{~min}$ & $10 \mathrm{~min}$ & $2 \mathrm{~min}$ & $10 \mathrm{~min}$ \\
\hline $\mathrm{CaCl}_{2}$ & $325 \pm 94$ & $309 \pm 123$ & $2 \pm 1$ & $2 \pm 1$ & $2 \pm 1$ & $3 \pm 1$ \\
\hline $48 / 80$ & $24 \pm 5^{\circ}$ & $38 \pm 4^{\circ}$ & $<0.3$ & $<0.3$ & $<1$ & $<1$ \\
\hline $\mathrm{CaCl}_{2}+48 / 80$ & $613 \pm 68$ & $392 \pm 53$ & $59 \pm 3$ & $56 \pm 4$ & $36 \pm 13$ & $42 \pm 16$ \\
\hline
\end{tabular}

Fura-2-loaded mast cells with depleted in $\mathrm{Ca}^{2+}$ stores were prepared as described in Materials and Methods. The responses evoked by the addition of $\mathrm{CaCl}_{2}(1 \mathrm{mM})$ and/or compound 48/80 (48/80, 10 $\mu \mathrm{g} / \mathrm{ml}$ ) were determined at 2 and $10 \mathrm{~min}$ after activation. Data are presented as described in Table 5.1. Results are mean values \pm SEM $(n=3)$.

- Control incubations without compound $48 / 80$ showed a comparable rise in $\left./ \mathrm{Ca}^{2+}\right]_{i}$.

Effects of Protein Tyrosine Kinase Inhibitors on the Release of Histamine and $\mathrm{PGD}_{2}$ by Mast Cells

The role of protein tyrosine kinases in the release of histamine and $\mathrm{PGD}_{2}$ from mast cells was studied by using two structurally unrelated inhibitors of these signaling components: methyl-2,5-dihydroxycinnamate and genistein. After pre-incubation with these inhibitors, mast cells were stimulated with compound $48 / 80$ or thapsigargin in the presence of $\mathrm{CaCl}_{2}$. Histamine secretion induced by compound $48 / 80$ was not influenced by either inhibitor (Table 5.3), whereas the $\mathrm{PGD}_{2}$ release by this agonist was considerably reduced. With thapsigargin as agonist, histamine secretion was moderately influenced by both methyl-2,5-dihydroxycinnamate and genistein, in contrast to the $\mathrm{PGD}_{2}$ release which, again, was potently inhibited (Table 5.3). Similar effects of these tyrosine kinase inhibitors were found, when the cells were stimulated with ionomycin instead of thapsigargin (data not shown). 
Table 5.3: Effects of Protein Tyrosine Kinase Inhibitors on Histamine Secretion and $P G D_{2}$ Release by Stimulated Mast Cells

\begin{tabular}{|c|c|c|c|c|}
\hline \multirow[t]{2}{*}{ Addition } & \multicolumn{2}{|c|}{$\begin{array}{c}\text { Histamine Secretion } \\
\text { (\% of total) }\end{array}$} & \multicolumn{2}{|c|}{$\begin{array}{l}\mathrm{PGD}_{2} \text { Release } \\
\text { (ng/106 cells) }\end{array}$} \\
\hline & Compound $48 / 80$ & Thapsigargin & Compound $48 / 80$ & Thapsigargin \\
\hline DMSO & $70.3 \pm 2.4$ & $23.3 \pm 1.3^{\mathrm{a}}$ & $6.0 \pm 0.7^{a}$ & $17.3 \pm 4.3^{\mathrm{a}}$ \\
\hline $\mathrm{DHC}$ & $61.0 \pm 5.5$ & $14.5 \pm 1.7^{b}$ & $1.3 \pm 0.3^{b}$ & $6.0 \pm 1.4^{b}$ \\
\hline GS & $66.5 \pm 4.5$ & $12.5 \pm 1.3^{b}$ & $1.0 \pm 0.6^{b}$ & $1.0 \pm 0.4^{b}$ \\
\hline
\end{tabular}

Mast cells were pre-incubated with $0.2 \%(w / v)$ dimethyl sulfoxide (DMSO, vehicle control), with $5 \mu \mathrm{M}$ methyl-2,5-dihydroxycinnamate (DHC) or with $100 \mu \mathrm{M}$ genistein (GS) during $45 \mathrm{~min}$. The cells were subsequently stimulated with $10 \mu \mathrm{g} / \mathrm{ml}$ compound $48 / 80$ or with $5 \mu \mathrm{M}$ thapsigargin in the presence of $1 \mathrm{mM} \mathrm{CaCl} 2$. The release of histamine and $P \mathrm{CD}_{2}$ from the cells was determined at $10 \mathrm{~min}$ after activation. Data are presented as described in Table 5.1 and represent mean values \pm SEM $(n=4)$. Within each column, rows with different superscripts differ significantly from each other ( $P \leq 0.05)$.

\subsection{DISCUSSION}

\section{Role of Store-regulated $\mathrm{Ca}^{2+}$ Influx in Histamine and $\mathrm{PGD}_{2}$ Release}

Activation of rat peritoneal mast cells with the G protein-activating compound $48 / 80$ and the endomembrane $\mathrm{Ca}^{2+}$-ATPase inhibitor thapsigargin resulted in $\mathrm{Ca}^{2+}$ signals, which consisted of a relatively small component representing mobilization of $\mathrm{Ca}^{2}+$ from internal stores and a larger component representing influx of $\mathrm{Ca}^{2+}$ from the extracellular medium. Several lines of evidence suggested that the $\mathrm{Ca}^{2+}$-influx caused by these agonists amplified the rises in $\left[\mathrm{Ca}^{2+}\right]_{i}$ evoked by store depletion and occurred through the store-regulated influx pathway: (i) compound $48 / 80$ as well as the endomembrane-active thapsigargin induced rises in $\left[\mathrm{Ca}^{2+}\right]_{i}$ which were of similar shape in the presence and absence of $\mathrm{CaCl}_{2}$, notwithstanding the higher amplitude reached with $\mathrm{CaCl}_{2}$; (ii) upon stimulation of the cells with compound $48 / 80$ or thapsigargin in the presence of $\mathrm{Mn}^{2+}$, two separate decreases in fura-2-fluorescence were observed; (iii) when extracellular $\mathrm{Ca}^{2+}$ was present, only the $\mathrm{CaCl}_{2}$-dependent part of $\left[\mathrm{Ca}^{2+}\right]_{\text {i }}$ rises was suppressed by the $\mathrm{Ca}^{2+}$ entry blocker $\mathrm{Ni}^{2+}$; (iv) in mast cells with depleted $\mathrm{Ca}^{2+}$ stores, addition of $\mathrm{CaCl}_{2}$ was sufficient to evoke an immediate and high increase in $\left[\mathrm{Ca}^{2+}\right]_{i}$, as predicted by the store-regulated pathway. ${ }^{35}$ In many other cells types in which this influx pathway is identified, including the rat mast cell line RBL- $2 \mathrm{H} 3^{2,7,17}$, similarly, store-regulated influx is known to be initiated by $\mathrm{G}$ protein-mediated activation of phospholipase $\mathrm{C}$ and by inhibition of thapsigargin-sensitive $\mathrm{Ca}^{2+}$-ATPases in the store membranes. The mechanism responsible for this type of $\mathrm{Ca}^{2+}$ influx is still unclear, although some proposals have been made, such as the release of an intermediary messenger other than $\mathrm{Ca}^{2+}$ from the store compartments. ${ }^{35,37}$

Our data indicate that the relatively high levels of $\left[\mathrm{Ca}^{2+}\right]_{i}$ caused by entry of external $\mathrm{Ca}^{2+}$ potentiated the secretion of histamine as well as that of $\mathrm{PGD}_{2}$ from mast cells. On the other hand, there were several activation conditions, where a considerable increase in $\left[\mathrm{Ca}^{2+}\right]_{i}$ was not accompanied by an appreciable release of histamine or $\mathrm{PGD}_{2}$. For instance, stimulation of mast cells with ATP4- and $\mathrm{CaCl}_{2}$ resulted in only marginal histamine secretion and no detectable $\mathrm{PGD}_{2}$ release despite a micromolar rise in 
$\left[\mathrm{Ca}^{2+}\right]_{i}$. Furthermore, the addition of $\mathrm{CaCl}_{2}$ to store-depleted cells resulted in a prolonged increase in $\left[\mathrm{Ca}^{2+}\right]_{i}$ of about $300 \mathrm{nM}$, but not in the release of histamine or $\mathrm{PGD}_{2}$. Typically, in both cases, the $\mathrm{Ca}^{2+}$ responses of mast cells consisted entirely of $\mathrm{Ca}^{2+}$ influx, whereas under conditions where significant amounts of histamine and $\mathrm{PGD}_{2}$ were released, i.e., in mast cells activated with compound $48 / 80$, thapsigargin or ionomycin, $\mathrm{Ca}^{2+}$ influx was always accompanied by release of $\mathrm{Ca}^{2+}$ from the intracellular stores. Thus, these results suggest that (intracellular signaling-events associated with) the influx of extracellular $\mathrm{Ca}^{2+}$ amplifies the release of histamine and $\mathrm{PGD}_{2}$, but that the influx of $\mathrm{Ca}^{2+}$ as such is insufficient to trigger these events. Whereas the additional factors required for exocytosis most likely include activation of protein kinase $C^{13,34}$, the signaling factors required for eicosanoid formation are less clear (see below).

\section{Differential Release of Histamine and $P G D_{2}$ by Activated Mast cells}

Mast cell-activating agonists may be divided into two types: agonists which are more efficient in evoking histamine secretion and those which are more efficient in evoking $\mathrm{PGD}_{2}$ release. We found that compound $48 / 80$, which directly activates $G$ proteins, strongly promoted histamine release, whereas thapsigargin and ionomycin were more potent in promoting $\mathrm{PGD}_{2}$ release. These preferential actions appeared to be independent of the presence or absence of external $\mathrm{CaCl}_{2}$ and, thus, of the agonistinduced rise in $\left[\mathrm{Ca}^{2+}\right]_{i}$. Since compound $48 / 80$ evoked a Ca${ }^{2+}$ signal that was shorter than that evoked by thapsigargin and ionomycin, these findings suggest that especially the duration of relatively high levels of $\left[\mathrm{Ca}^{2+}\right]_{i}$, but not the absolute rise in $\left[\mathrm{Ca}^{2+}\right]_{i}$ is a decisive factor in promoting $\mathrm{PGD}_{2}$ release. These results are consistent with earlier observations showing that in mast cells, G protein-activating compounds like substance $P$, compound $48 / 80$ and bradykinin evoke a relatively high histamine secretion 9,22 , whereas the $\mathrm{Ca}^{2+}$ ionophore $\mathrm{A} 23187$ and anti-immunoglobulin $\mathrm{E}$ are more efficient in evoking $\mathrm{PGD}_{2}$ release. , $^{, 9,20,22}$

When $\mathrm{CaCl}_{2}$ was added to store-depleted mast cells, this resulted in the release of only minor amounts of histamine and $\mathrm{PGD}_{2}$, despite the persistently high level of $\left[\mathrm{Ca}^{2+}\right]_{i}$ reached. However, when $\mathrm{CaCl}_{2}$ was added in combination with compound $48 / 80$, the prolonged $\mathrm{Ca}^{2+}$ signal was accompanied by a high release of histamine and $P G D_{2}$. This partially contrasts with the low formation of $P D_{2}$ and high secretion of histamine, when 'control' mast cells (i.e., mast cells with full $\mathrm{Ca}^{2+}$ stores) were activated with compound $48 / 80$ in the presence of $\mathrm{CaCl}_{2}$. The high histamine secretion with this agonist is probably caused by activation of protein kinase $C^{13,34}$ and/or the newly identified $G$ protein, $G_{i 3}$. It is tempting to suggest, that the high $\mathrm{PGD}_{2}$ release is a consequence of emptying of the intracellular $\mathrm{Ca}^{2+}$ stores in combination with prolonged high levels of $\left[\mathrm{Ca}^{2+}\right]_{\mathrm{i}}$ : compound $48 / 80$ allowed the store-depleted cells to empty the $\mathrm{Ca}^{2+}$ stores, once these had been filled by the store-regulated influx pathway evoked by the addition of $\mathrm{CaCl}_{2}$. Similar activation conditions were present, when cells with full stores were stimulated with thapsigargin or ionomycin in the presence of $\mathrm{CaCl}_{2}$. 


\section{Roles of Protein Tyrosine Kinases in the Release of Histamine and $\mathrm{PGD}_{2}$}

We found that genistein and methyl-2,5-dihydroxycinnamate, two well-known inhibitors of protein tyrosine kinases, suppressed $\mathrm{PGD}_{2}$ formation much more than histamine secretion in mast cells that were activated with compound $48 / 80$ and thapsigargin. Although we did not measure protein phosphorylation patterns directly, these results suggest that tyrosine kinases are more prominently involved in the reactions leading to activation of phospholipase $A_{2}$ than in those mediating exocytosis. There is recent evidence that protein tyrosine kinases are, indeed, involved in eicosanoid formation. For instance, from experiments with the same or similar tyrosine kinase inhibitors, it has been shown that tyrosine phosphorylation events contributed to the production of prostaglandin $E_{2}$ by murine macrophages ${ }^{12}$ and to the mobilization of arachidonic acid in platelets ${ }^{30}$ and in mast cells that were activated with stem cell factor. $^{21}$

Typically, genistein and methyl-2,5-dihydroxycinnamate strongly influenced the relative amounts of histamine and $\mathrm{PGD}_{2}$ that were released by mast cells in response to thapsigargin: in the presence of the tyrosine kinase inhibitors, thapsigargin changed from a good $\mathrm{PGD}_{2}$ releaser to a relatively better histamine releaser. In several other cell systems, including rat mastocytoma RBL- $2 \mathrm{H} 3$ cells, it has been demonstrated that compounds like thapsigargin, ionomycin and A23187 cause tyrosine phosphorylation of a whole series of proteins. ${ }^{29,38,40,45,48}$ Thus, it is possible that the property of these $\mathrm{Ca}^{2+}$-mobilizing compounds to preferentially evoke $\mathrm{PGD}_{2}$ release is related to their effect to stimulate protein tyrosine kinases.

Studies with RBL- $2 \mathrm{H} 3$ cells have shown that the secretion of histamine evoked by A23187, thapsigargin and anti-immunoglobulin E is modulated by tyrosine kinase or phosphatase inhibitors, suggesting that these enzymes also have a regulatory function in ionophore- and antigen-evoked exocytosis. ${ }^{38,48}$ In agreement with this, we found that in rat mast cells histamine secretion evoked by thapsigargin and ionomycin was moderately reduced by protein tyrosine kinase inhibition, in contrast to the secretion evoked by compound $48 / 80$, which was not influenced. The latter effect is well compatible with the evidence that signaling pathways involving protein tyrosine phosphorylation in RBL-2H3 cells act largely independently of the activation by protein kinase $\mathrm{C}^{41}$

The cytoplasmic, $85-\mathrm{kDa}$ phospholipase $\mathrm{A}_{2}$ is considered to mediate agoniststimulated release of arachidonic acid in many cell types. ${ }^{24,28}$ Recent data indicate that the activation of $p 85$ phospholipase $A_{2}$ requires, besides elevation in $\left[\mathrm{Ca}^{2+}\right]_{i}, a$ phosphorylation step which is putatively catalyzed by mitogen-associated protein kinases (MAP kinases). ${ }^{24,31}$ MAP kinases belong to a family of serine/threonine kinases which can be activated by phosphorylation of their tyrosine and threonine residues and may serve as convergence points in intracellular signal transduction. ${ }^{32}$ It is known that arachidonic acid mobilizing agents activate MAP kinases and cause increased phosphorylation of p85 phospholipase $\mathrm{A}_{2}{ }^{24,30}$ For instance, in rat RBL-2H3 cells activated with $\mathrm{A} 23187$ or thapsigargin ${ }^{38}$ and in cultured mouse mast cells activated with anti-immunoglobulin E or stem cell factor ${ }^{43}$, MAP kinases or related enzymes appeared to be phosphorylated on tyrosine. Taken together, these findings lead to the 
conclusion that the potency of such agonists to favour the release of $\mathrm{PGD}_{2}$ in mast cells might be a consequence of their ability to phosphorylate and activate MAP kinases and/or phospholipase $\mathrm{A}_{2}$.

In summary, our results indicate that in rat peritoneal mast cells, the store-regulated influx of $\mathrm{Ca}^{2+}$ forms a major contribution to the agonist-evoked increase in $\left[\mathrm{Ca}^{2+}\right]_{i}$ and is a potentiating factor in the release of histamine as well as $\mathrm{PGD}_{2}$. However, the influx of $\mathrm{Ca}^{2+}$ as such appears to be insufficient to promote a substantial release of these compounds. Three factors may contribute to a high release of $\mathrm{PGD}_{2}$ by mast cell agonists: (i) prolonged high levels of $\left[\mathrm{Ca}^{2+}\right]_{i}$, (ii) emptying of the intracellular $\mathrm{Ca}^{2+}$ stores and (iii) the phosphorylation at tyrosine of proteins involved in the phospholipase $\mathrm{A}_{2}$ mediated signal transduction cascade. It has been reported that in human platelets, activated with $\mathrm{Ca}^{2+}$ ionophore or thapsigargin, tyrosine phosphorylation and dephosphorylation are controlled by the cytosolic and stored $\mathrm{Ca}^{2+}$ concentrations. ${ }^{45}$ Hence, also in mast cells these three factors may not be mutually independent.

\subsection{REFERENCES}

1. Akiyami, T., Ishida, J., Nakagawa, S., Ogawara, H., Watanabe, S.-I., Itoh, N., Shibuya, M. and Fukami, Y. (1987) Genistein, a specific inhibitor of tyrosine-specific protein kinases. I Biol Chem 262, 5592-5595.

2. Ali, H., Cunha-Melo, J.R., Saul, W.F. and Beaven, M.A. (1990) Activation of phospholipase C via adenosine receptors provides synergistic signals for secretion in antigen-stimulated $\mathrm{RBL}-2 \mathrm{H} 3$ cells. Evidence for a novel adenosine receptor. J Biol Chem 265, 745-753.

3. Aridor, M., Rajmilevich, G., Beaven, M.A. and Sagi-Eisenberg, R. (1993) Activation of exocytosis by heterotrimeric $G$ protein $G_{i 3}$. Science 262, 1569-1571.

4. Benyon, R.C., Robinson, C. and Church, M.K. (1989) Differential release of histamine and eicosanoids from human skin mast cells activated by IgE-dependent and non-immunological stimuli. Br J Pharmacol 87, 898-904.

5. Church, M.K., El-Lati, S. and Caulfield, J.P. (1991) Neuropeptide-induced secretion from human skin mast cells. Int Arch Allergy Appl Immunol 94, 314-318.

6. Churcher, Y., Allan, D. and Gomperts, B.D. (1990) Relationship between arachidonate generation and exocytosis in permeabilized mast cells. Biochem J 266, 157-163.

7. Dar, O. and Pecht, I. (1992) Fc epsilon receptor mediated calcium influx into mast cells is modulated by the concentration of cytosolic free calcium ions. FEBS Lett 310, 123-128.

8. Ellati, S.G., Dahinden, C.A. and Church, M.K. (1994) Complement peptides C3a and C5ainduced mediator release from dissociated human skin mast cells. J Invest Dermatol 102, 803806.

9. Ennis, M., Barrow, S.E. and Blair, I.A. (1984) Prostaglandin and histamine release from stimulated peritoneal mast cells. Agents Actions 14, 397-400.

10. Fasolato, C., Hoth, M. and Penner, R. (1993) Multiple mechanisms of manganese-induced quenching of fura-2-fluorescence in rat mast cells. Pflügers Arch 423, 225-231.

11. Giles, $H$. and Leff, P. (1988) The biology and pharmacology of $P G D_{2}$. Prostaglandins 35, 277. 300.

12. Glaser, K.B., Sung, A., Bauer, J. and Weichman, B.M. (1993) Regulation of eicosanoid biosynthesis in the macrophage. Involvement of protein tyrosine phosphorylation and modulation by selective protein tyrosine kinase inhibitors. Biochem Pharmacol 45, 711-721.

13. Gomperts, B.D., Churcher, Y., Koffer, A., Lillie, T.H.W., Tatham, P.E.R. and Whalley, T.D. (1991) Intracellular mechanisms regulating exocytotic secretion in mast cells. Int Arch Allergy Appl Immunol 94, 38-46.

14. Grynkiewicz, G., Poenie, M. and Tsien, R.Y. (1985) A new generation of calcium indicators with greatly improved fluorescence properties. I Biol Chem 260, 3440-3450.

15. Hallam, T.J. and Rink, T.J. (1985) Quenching of fura-2-fluorescence using manganese. FEBS Lett $186,175-179$. 
16. Heemskerk, J.W.M., Feijge, M.A.H., Rietman, E. and Hornstra, G. (1991) Rat platelets are deficient in internal $\mathrm{Ca}^{2+}$ release and require influx of extracellular $\mathrm{Ca}^{2+}$ for activation. FEBS Lett 284, 223-226.

17. Hide, M. and Beaven, M.A. (1991) Calcium influx in a rat mast cell (RBL-2H3) line. J Biol Chem 266, 15221-15229.

18. Ito, S., Narumiya, S. and Hayaishi, O. (1989) Prostaglandin $D_{2}$ : a biochemical perspective. Prostaglandins Leukot Essent Fatty Acids 37, 219-234.

19. Kast, R., Furstenberger, G. and Marks, F. (1993) Activation of cytosolic phospholipase $A_{2}$ by transforming growth factor-alpha in HEL-30 keratinocytes. J Biol Chem 268, 16795-16802.

20. Kawabe, H., Hayashi, H. and Hayaishi, O. (1987) Differential calcium effects on prostaglandin $D_{2}$ generation and histamine release from isolated rat peritoneal mast cells. Biochem Biophys Res Commun 143, 467-474.

21. Koike, T., Mizutani, T., Hirai, K., Morita, Y. and Nozawa, Y. (1993) SCF/c-kit receptor-meditated arachidonic acid liberation in rat mast cells. Biochem Biophys Res Commun 197, 1570-1577.

22. Levi-Schaffer, F. and Shalit, M. (1989) Differential release of histamine and prostaglandin $D_{2}$ in rat peritoneal mast cells activated with peptides. Int Arch Allergy Appl Immunol 90, 352-357.

23. Lewis, R.A., Soter, N.A., Diamond, P.T., Austen, K.F., Oates, J.A. and Roberts, L.J.I. (1982) Prostaglandin $\mathrm{D}_{2}$ generation after activation of rat and human mast cells with anti-lgE. J Immunol $129,1627-1631$.

24. Lin, L.-L., Wartmann, M., Lin, A.Y., Knopf, J.L., Seth, A. and Davis, R.J. (1993) $C P L A_{2}$ is phosphorylated and activated by MAP kinase. Cell 72, 269-278.

25. Lindau, M. and Gomperts, B.D. (1991) Techniques and concepts in exocytosis: focus on mast cells. Biochim Biophys Acta 1071, 429-471.

26. Metcalfe, D.D., Kaliner, M. and Donlon, M.A. (1981) The mast cell. Crit Rev Immunol 3, 23-74.

27. Mousli, M., Bronner, C., Landry, Y., Bockaert, J. and Rouot, B. (1990) Direct activation of GTPbinding regulatory proteins ( $G$ proteins) by substance $P$ and compound 48/80. FEBS Lett 259 , 260-262.

28. Murakami, M., Kudo, I., Umeda, M., Matsuzawa, A., Takeda, M., Komada, M., Fujimori, Y., Takahshi, K. and Inoue, K. (1992) Detection of three distinct phospholipases $A_{2}$ in cultured mast solls , Rionhom 313, 3.75. 3.93.

29. Murphy, C.T., Kellie, S. and Westwick, J. (1993) Tyrosine-kinase activity in rabbit platelets stimulated with platelet-activating factor. Eur I Biochem 216, 639-651.

30. Nakashima, S., Chatani, Y., Nakamura, M., Miyoshi, N., Kohno, M. and Nozawa, Y. (1994) Tyrosine phosphorylation and activation of mitogen-activated protein kinases by thrombin in human platelets: possible involvement in late arachidonic acid release. Biochem Biophys Res Commun 198, 497-503.

31. Nemenoff, R.A., Winitz, S., Qian, N.-X., Van Putten, V., Johnson, G.L. and Heasley, L.E. (1993) Phosphorylation and activation of a high molecular weight form of phospholipase $A_{2}$ by $p 42$ microtubule-associated protein 2 kinase and protein kinase C. J Biol Chem 268, 1960-1964.

32. Nishida, E. and Gotoh, Y. (1993) The MAP kinase cascade is essential for diverse signal transduction pathways. Trends Biochem Sci 18, 128-131.

33. Osipchuk, Y. and Cahalan, M. (1992) Cell to cell spread of calcium signals mediated by ATP receptors in mast cells. Nature 359, 241-244.

34. Penner, R. (1988) Multiple signaling pathways control stimulus-secretion coupling in rat peritoneal mast cells. Proc Natl Acad Sci USA 85, 9856-9860.

35. Putney, J.W. (1990) Capacitative calcium entry revisited. Cell Calcium 11, 611-624.

36. Putney, J.W. and Bird, G.S.J. (1993) The inositol phosphate-calcium signaling system in nonexcitable cells. Endocrin Rev 14, 610-631.

37. Randriamampita, C. and Tsien, R.Y. (1993) Emptying of intracellular $\mathrm{Ca}^{2+}$ stores releases a novel small messenger that stimulates $\mathrm{Ca}^{2+}$ influx. Nature 364, 809-814.

38. Santini, F, and Beaven, M.A. (1993) Tyrosine phosphorylation of a mitogen-activated protein kinase-like protein occurs at a late step in exocytosis. I Biol Chem 268, 22716-22722.

39. Sargeant, P., Clarkson, W.D., Sage, S.O. and Heemskerk, J.W.M. (1992) Calcium influx evoked by $\mathrm{Ca}^{2+}$ store depletion in human platelets is more susceptible to cytochrome P-450 inhibitors than receptor-mediated calcium entry. Cell Calcium 13, 553-564.

40. Sargeant, P., Farndale, R. and Sage, S.O. (1993) ADP- and thapsigargin-evoked $\mathrm{Ca}^{2+}$ entry and protein-tyrosine phosphorylation are inhibited by the tyrosine kinase inhibitors genistein and methyl-2,5-dihydroxycinnamate in fura-2-loaded human platelets. I Biol Chem 268, 1815118156 . 
41. Stephan, V., Benhamou, M., Gutkind, J.S., Robbins, K.C. and Siraganian, R.P. (1992) Fc epsilon Rl-induced protein tyrosine phosphorylation of $p p 72$ in rat basophilic leukemia cells (RBL-2H3). Evidence for a novel signal transduction pathway unrelated to $G$ protein activation and phosphatidylinositol hydrolysis. I Biol Chem 267, 5434-5441.

42. Tatham, P.E.R. and Lindau, M. (1990) ATP-induced pore formation in the plasma membrane of rat peritoneal mast cells. J Gen Physiol 95, 459-476.

43. Tsai, M., Chen, R.-H., Tam, S.-Y., Blenis, J. and Galli, S.J. (1993) Activation of MAP kinases. Eur J Immunol 23, 3286-3291.

44. Umezawa, K., Hori, T., Tajima, H., Imoto, M., Isshiki, K. and Takeuchi, T. (1990) Inhibition of epidermal growth factor-induced DNA synthesis by tyrosine kinase inhibitors. FEBS Lett 260, 198-200.

45. Vostal, J., Jackson, W.L. and Shulman, N.R. (1991) Cytosolic and stored calcium antagonistically control tyrosine phosphorylation of specific platelet proteins. J Biol Chem 266, 16911-16916.

46. Wu, C.Y., Chen, C.F. and Chiang, C.F. (1993) Stimulation of inositol phosphate production and GTP-ase activity by compound $48 / 80$ in rat peritoneal mast cells. Biochem Biophys Res Commun 192, 204-213.

47. Yamada, K., Okano, Y., Miura, K. and Nozawa, Y. (1987) A major role for phospholipase $A_{2}$ in antigen-induced arachidonic acid release in rat mast cells. Biochem J 247, $95-99$.

48. Yu, K.T., Lyall, R., Jariwala, N., Zilberstein, A. and Haimovich, J. (1991) Antigen- and ionophoreinduced signal transduction in rat basophilic leukemia cells involves protein tyrosine phosphorylation. J Biol Chem 266, 22564-22568. 


\section{| CHAPTER 6}

The Effect of Antigen-induced Mast Cell Degranulation on LDH Release in the Ischemic and Reperfused Rat Heart 


\subsection{ABSTRACT}

In the present study, the role of mast cells in ischemia/reperfusion-induced injury to cardiomyocytes was evaluated in the isolated rat heart. Hearts were isolated from sensitized and non-sensitized rats and perfused according to Langendorff. After 30 min of normoxic perfusion, hearts were challenged with antigen, a procedure which is known to result in a massive mast cell degranulation in sensitized hearts. After another $20 \mathrm{~min}$, both 'mast cell-depleted' and control hearts were subjected to 30 min of ischemia followed by $30 \mathrm{~min}$ of reperfusion. The release of lactate dehydrogenase (LDH) was determined to quantitate the extent of (irreversible) injury to cardiomyocytes. Coronary flow (CF) and left ventricular developed pressure (LVDP) were monitored to study the consequences of the procedures on hemodynamic parameters. It was found that both CF and LVDP significantly increased during the first min after antigen challenge. The increase in CF and LVDP values were rapidly followed by a decrease, reaching minimal values of $59 \pm 4 \%$ and $85 \pm 4 \%$ of those before administration of antigen, respectively, at 2-3 min after antigen challenge. Antigen challenge did not have any significant effects on CF and LVDP in control hearts. No effects of antigen challenge on $L D H$ release were found. During reperfusion, after 30 min of ischemia, both the increase in CF and LVDP in 'mast cell-depleted' (sensitized) were not significantly different from those in control, non-sensitized, hearts. Similarly, at the end of the reperfusion-phase, CF and LVDP values in sensitized hearts were comparable to those in control hearts. Reperfusion resulted in increased $\mathrm{LDH}$ release, which at no point in time was significantly different between sensitized and non-sensitized hearts. The results from the present study provide no evidence that in the isolated rat heart, mast cells are prominently involved in ischemia/reperfusioninduced injury to cardiomyocytes.

\subsection{INTRODUCTION}

Over the past three decades, it has become clear that in the heart prolonged ischemia initiates a sequence of events that become increasingly severe and, unless halted by reperfusion, will result in irreversible myocardial injury and cell death. ${ }^{3}$ Reperfusion, although a prerequisite for survival of the ischemic tissue, is generally associated with a sudden exacerbation of injury to the myocardium. ${ }^{4}$ Various mechanisms such as the generation of oxygen free radicals, calcium overload and ATP depletion have been proposed to jeopardize directly or indirectly the integrity of myocardial membranes. $7,9,11$ In recent years, much attention has been paid to mechanisms contributing to the extent of ischemia/reperfusion-induced myocardial injury.

Two studies have provided indirect evidence that mast cells are involved in myocardial injury. Observations from Jolly et al. ${ }^{5}$ have indicated that in the heart in vivo, stabilization of resident mast cells by lodoxamide significantly reduced the extent of ischemia/reperfusion-induced myocardial injury, measured as ultimate infarct size at 24 hours postmortem. In addition, Keller et al. ${ }^{6}$ have shown that stabilization of mast cells by lodoxamide significantly reduced the extent of (irreversible) injury to cardiomyocytes 
during hypoxia/reoxygenation. The mechanisms by which mast cells cause cardiac tissue injury are largely unknown, but may be due to their release of peroxidases or proteinases. $^{6}$

We studied the role of mast cells in ischemia/reperfusion-induced injury to cardiomyocytes in a more direct way. To this end, hearts isolated from sensitized or non-sensitized rats, were challenged with antigen (trinitro-phenyl-haptenized ovalbumin, TNP-OVA) during normoxic perfusion. This procedure has been shown to specifically result in a massive mast cell degranulation in sensitized hearts, a phenomenon which is absent in non-sensitized, control, hearts. ${ }^{13}$ After 20 min, 'mast cell-depleted' and control hearts were subjected to $30 \mathrm{~min}$ of ischemia and $30 \mathrm{~min}$ of reperfusion. The activity of lactate dehydrogenase (LDH) in coronary effluents was determined to quantitate the extent of (irreversible) injury to cardiomyocytes. In order to study the consequences of the procedures on hemodynamic parameters, coronary flow (CF) and left ventricular developed pressure (LVDP) were monitored.

It was found that reperfusion of the ischemic heart resulted in an increased LDH release, which at no point in time was significantly different between sensitized and non-sensitized, control, hearts. The results provide no evidence that in the isolated rat heart, mast cells are prominently involved in acute ischemia/reperfusion-induced injury to cardiomyocytes.

\subsection{MATERIALS AND METHODS}

Conoritiantion, Poccordren

Wistar rats (body weight 180-200 g) were sensitized by an intraperitoneal injection of a $2 \mathrm{ml}$ suspension of trinitro-phenyl-haptenized ovalbumin (TNP-OVA) as described by Ufkes et al. ${ }^{12} \mathrm{AlPO}_{4}$ was used as adjuvant. Control, non-sensitized animals were injected vehicle instead of TNP-OVA. After 21 days, the animals were used for the experiments. Animals had free access to food and water.

\section{Experimental Set-up}

Hearts, isolated from heparinized rats (5000 IU/kg i.p.), were immediately mounted for perfusion by the Langendorff technique. Perfusion pressure was kept constant at $80 \mathrm{~mm}$ $\mathrm{Hg}$. The perfusion buffer $(\mathrm{pH} 7.4)$ was Krebs-Ringer containing (in $\mathrm{mM}$ ): $\mathrm{NaCl}(128.0$ ), $\mathrm{KCl}$ (4.7), $\mathrm{MgCl}_{2}$ (0.6), $\mathrm{NaH}_{2} \mathrm{PO}_{4}(0.4), \mathrm{NaHCO}_{3}$ (27.0), $\mathrm{CaCl}_{2}$ (1.3) and glucose (11.0). The Krebs-Ringer solution was kept at $37{ }^{\circ} \mathrm{C}$ and equilibrated with $95 \% \mathrm{O}_{2} / 5 \% \mathrm{CO}_{2}$ $\left(\mathrm{PO}_{2}>80 \mathrm{kPa}\right)$ throughout the experiment. Left ventricular pressures were measured via a water-filled balloon (HSE, Freiburg, FRG) and recorded on a Gould recorder (type 2600 S, Gould Inc., Cleveland, USA). After an equilibration period of $30 \mathrm{~min}$, diastolic ventricular pressure was adjusted to $5 \mathrm{~mm} \mathrm{Hg}$. Left ventricular developed pressure (LVDP) was calculated as the difference between left ventricular systolic and enddiastolic pressure. The hearts were electrically driven at a frequency of $5 \mathrm{~Hz}$. Coronary flow was measured by timed collection of the amount of effluent dripping from the heart. 


\section{Protocol}

After a 30 min equilibration period, hearts ( $n=6$ per group) were administered a supramaximal bolus-injection of antigen ( $0.8 \mathrm{mg}$ TNP-OVA in a volume of $0.3 \mathrm{ml})$, directly into the perfusion stream. Normoxic perfusion was continued for another 20 min. Thereafter, hearts were subjected to $30 \mathrm{~min}$ of ischemia by stopping the perfusion. One min after the onset of ischemia, pacing was stopped. During the ischemic period, the temperature of the heart was kept constant at $37^{\circ} \mathrm{C}$. Hearts were reperfused for 30 min by restoring normoxic perfusion and were paced again. Coronary effluents for the determination of coronary flow and LDH content were continuously sampled during (a) the last $5 \mathrm{~min}$ of the equilibration period (one $5 \mathrm{~min}$ period), (b) five $1 \mathrm{~min}$ periods and three 5 min periods after antigen challenge, and (c) ten 1 min periods and four 5 min periods after reperfusion. Bovine serum albumin $(3 \%, w / v)$ was added to the coronary effluents in order to improve enzyme stability. Samples were immediately stored at -70 ${ }^{\circ} \mathrm{C}$.

\section{Determination of LDH Activity in Coronary Effluents}

$\mathrm{LDH}$-activity in coronary effluents was determined spectrophotometrically according to Bergmeyer et al. ${ }^{1}$ using a centrifugal analyzer (Cobas Bio System). LDH-activity was determined at $25^{\circ} \mathrm{C}, \mathrm{pH} 7.4$.

\section{Visualization of Antigen-Induced Mast Cell Degranulation}

In order to visualize the effects of antigen-induced mast cell degranulation, hearts ( $n=2$, for both sensitized and non-sensitized hearts) were challenged with antigen and normoxic perfusion was continued for another $20 \mathrm{~min}$. Thereafter, hearts were snapfrozen in dry ice-cooled isopentane and immediately stored at $-70{ }^{\circ} \mathrm{C}$. Sections (4-6 $\mu \mathrm{m})$ were cut, formalin-fixed and air dried for $60 \mathrm{~min}$. Sections were incubated with $0.5 \%$ toluidine blue for $2 \mathrm{~min}$. Thereafter, they were rapidly dehydrated and coverslipped with Entellan ${ }^{\circledR}$.

\section{Statistical Analysis}

Data are presented as mean values \pm SEM. Comparisons between groups were made using an Analysis of Variance. $\mathrm{P}$ values $\leq 0.05$ were considered to be statistically significant.

\subsection{RESULTS}

\section{Hemodynamic Parameters}

Before antigen challenge, no significant differences were observed between coronary flow (CF) values of sensitized $(7.4 \pm 0.4 \mathrm{ml} / \mathrm{min})$ and non-sensitized hearts $(7.0 \pm 0.4$ $\mathrm{ml} / \mathrm{min}$ ) (Fig. 6.1A). Similar results were obtained for left ventricular developed pressure (LVDP) values of sensitized $(74 \pm 1 \mathrm{~mm} \mathrm{Hg}$ ) and non-sensitized hearts $(77 \pm 4 \mathrm{~mm} \mathrm{Hg})$ (Fig. 6.1B). Antigen challenge did not affect CF and LVDP values in non-sensitized (control) hearts. At $20 \mathrm{~min}$ after antigen challenge, CF and LVDP values of these hearts attributed to $7.5 \pm 0.6 \mathrm{ml} / \mathrm{min}$ and $78 \pm 3 \mathrm{~mm} \mathrm{Hg}$, respectively. 

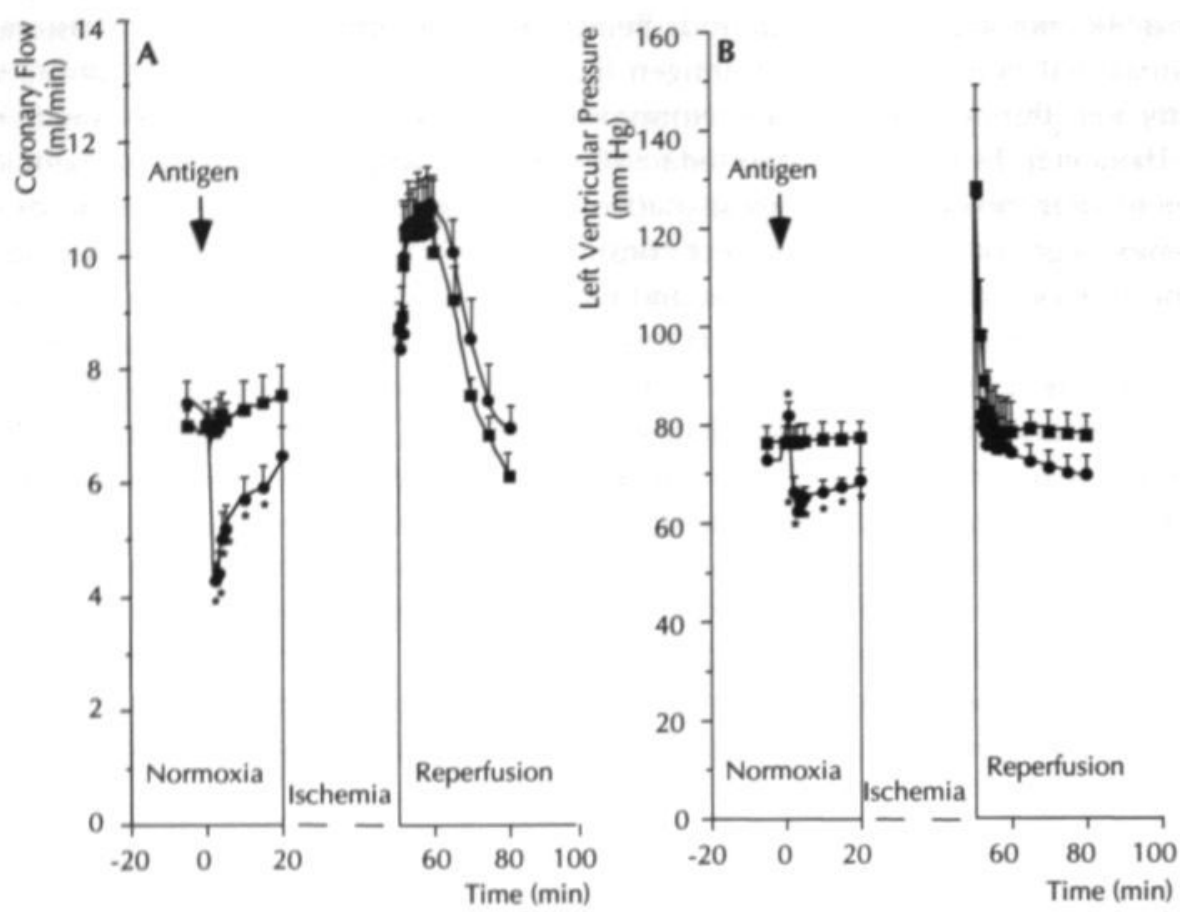

Figure 6.1: Hemodynamic Parameters: Coronary Flow and Left Ventricular Pressure Hearts isolated from sensitized (closed circles $\bullet$ ) or non-sensitized animals (closed squares $\mathbf{m}$ ) were subjected to $20 \mathrm{~min}$ of normoxia, $30 \mathrm{~min}$ of ischemia followed by $30 \mathrm{~min}$ of reperfusion (See Materials and Methods). At $t=0$, hearts were challenged with antigen (TNP-OVA)

- indicates statistically significant from corresponding value of control hearts

In sensitized hearts, antigen challenge resulted in a rapid increase in CF during the first $30 \mathrm{~s}$ (data not shown) which rapidly decreased during the next $30 \mathrm{~s}$, resulting in values which were slightly less than those observed before antigen challenge $(6.9 \pm 0.7$ $\mathrm{ml} / \mathrm{min}$ ) (Fig. 6.1 A). Thereafter, CF further decreased, reaching minimal values at $2 \mathrm{~min}$ after antigen challenge $(4.3 \pm 0.3 \mathrm{ml} / \mathrm{min})$. During the next $18 \mathrm{~min}$, CF steadily increased, reaching values of $6.5 \pm 0.5 \mathrm{ml} / \mathrm{min}$ at $20 \mathrm{~min}$ after antigen challenge (corresponding to CF values of $88 \pm 6 \%$ of those before antigen challenge). In sensitized hearts, administration of TNP-OVA resulted in a rapid increase in LVDP which reached maximal values of $83 \pm 3 \mathrm{~mm} \mathrm{Hg}$ at $1 \mathrm{~min}$ after antigen challenge (Fig. 6.1B). Thereafter, LVDP rapidly decreased during the next $2 \mathrm{~min}$, reaching minimal values at 3 min after antigen challenge $(63 \pm 4 \mathrm{~mm} \mathrm{Hg})$. During the next $17 \mathrm{~min}$, LVDP steadily increased, reaching values of $68 \pm 2 \mathrm{~mm} \mathrm{Hg}$ at $20 \mathrm{~min}$ after antigen challenge (corresponding to values of $93 \pm 3 \%$ of those before antigen challenge).

Reperfusion resulted in a transient increase in CF reaching maximal values of $10.7 \pm$ $0.8 \mathrm{ml} / \mathrm{min}$ and $10.3 \pm 0.5 \mathrm{ml} / \mathrm{min}$ in sensitized and non-sensitized hearts, respectively, at $7 \mathrm{~min}$ after reperfusion. Thereafter, coronary flow steadily decreased, reaching values 
of $7.0 \pm 0.4$ in sensitized hearts and $6.1 \pm 0.4 \mathrm{ml} / \mathrm{min}$ in non-sensitized hearts at $30 \mathrm{~min}$ after reperfusion. No significant differences were observed between CF values of sensitized and non-sensitized hearts. LVDP was highest during the first min after reperfusion, reaching values of $128 \pm 15 \mathrm{~mm} \mathrm{Hg}$ in sensitized hearts and $130 \pm 20 \mathrm{~mm}$ $\mathrm{Hg}$ in non-sensitized hearts. LVDP rapidly decreased thereafter, reaching values of $70 \pm$ $4 \mathrm{~mm} \mathrm{Hg}$ in sensitized hearts and $78 \pm 4 \mathrm{~mm} \mathrm{Hg}$ in non-sensitized hearts at $30 \mathrm{~min}$ after reperfusion. Again, no significant differences were observed between LVDP values of sensitized and non-sensitized hearts.

\section{$L \mathrm{DH}$ release}

In order to quantitate the extent of (irreversible) injury to cardiomyocytes, LDH-activity was determined in coronary effluents (Fig. 6.2).

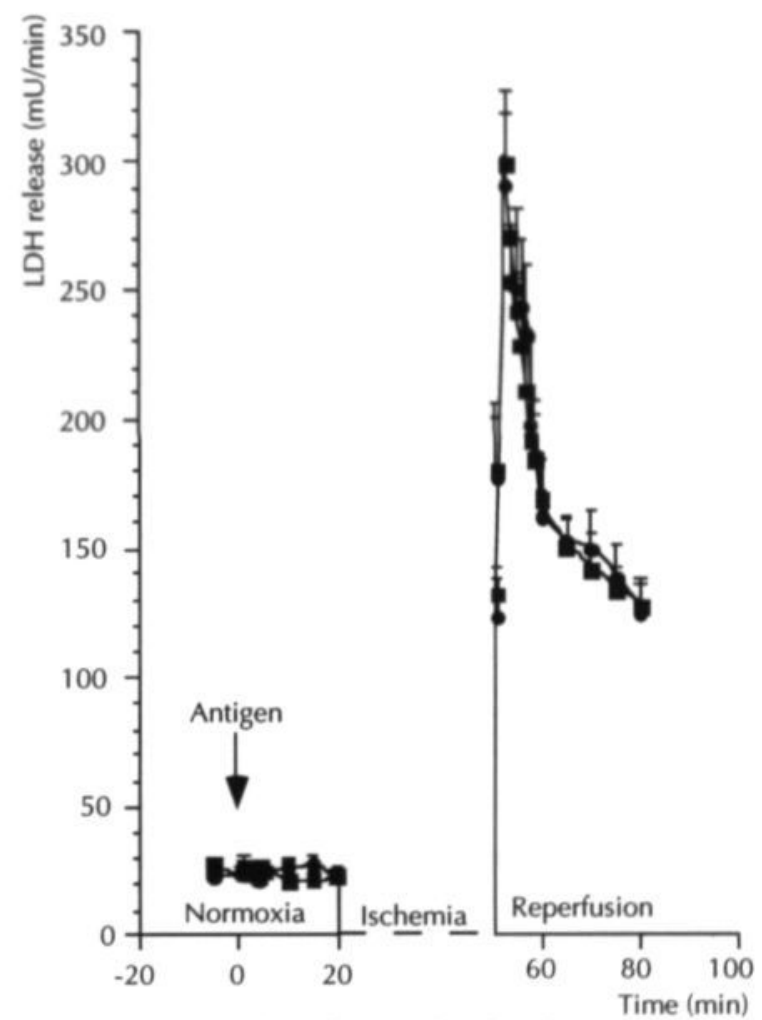

Figure 6.2: $\mathrm{LDH}$ release from isolated rat hearts

Hearts isolated from sensitized (closed circles, $\bullet$ ) or nonsensitized rats (closed squares, $\mathbf{0})$ were subjected to 20 min of normoxia, $30 \mathrm{~min}$ of ischemia followed by $30 \mathrm{~min}$ of reperfusion. At $t=0$ hearts were challenged with antigen (TNP-OVA)

During normoxic perfusion, LDH release was very low (about $25 \mathrm{mU} / \mathrm{min}$ ) and did not differ between sensitized and non-sensitized hearts. After antigen challenge, LDH release remained low in both groups. Reperfusion resulted in an increased release of $\mathrm{LDH}$, reaching maximal values of $288 \pm 29 \mathrm{mU} / \mathrm{min}$ in sensitized hearts and $297 \pm 29$ 


\section{CHAPTER 6}

$\mathrm{mU} / \mathrm{min}$ in non-sensitized hearts at $3 \mathrm{~min}$ after reperfusion. Thereafter, $\mathrm{LDH}$ release decreased, reaching values of $123 \pm 14 \mathrm{mU} / \mathrm{min}$ in sensitized hearts and $124 \pm 10$ $\mathrm{mU} / \mathrm{min}$ in non-sensitized hearts at $30 \mathrm{~min}$ after reperfusion. Cumulative $\mathrm{LDH}$ release of sensitized and non-sensitized hearts during $30 \mathrm{~min}$ of reperfusion attributed to $4.9 \pm$ $0.2 \mathrm{U} /$ heart and $4.8 \pm 0.4 \mathrm{U} /$ heart, respectively. No significant differences in $\mathrm{LDH}$ release during reperfusion were observed between sensitized and non-sensitized hearts.

\section{Mast Cell Degranulation}

In sections from non-sensitized, control hearts, mast cell degranulation was not observed after antigen challenge. In these hearts, mast cells showed a dense granular structure (Fig. 6.3A) In sensitized hearts, antigen-challenge resulted in a massive mast cell degranulation, as indicated by the presence of numerous granules, which were observed in the vicinity of degranulated mast cells and between cardiomyocytes. In these hearts, the dense granular structure of mast cells was lost (Fig. 6.3B).

\section{A}

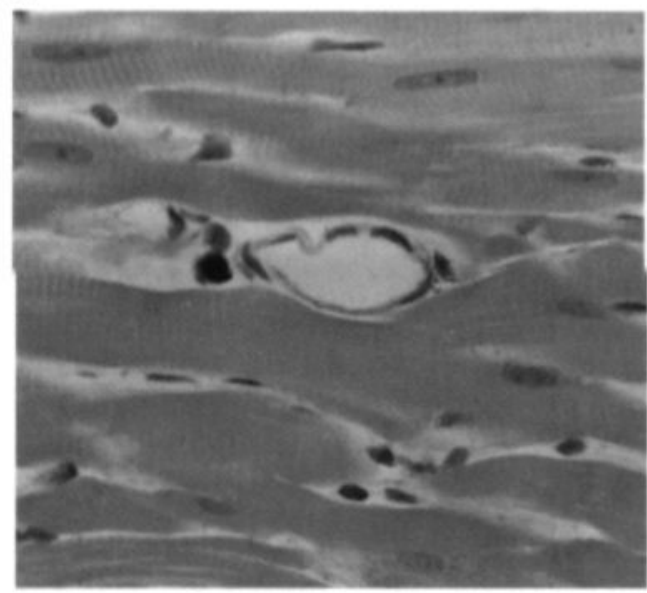

B

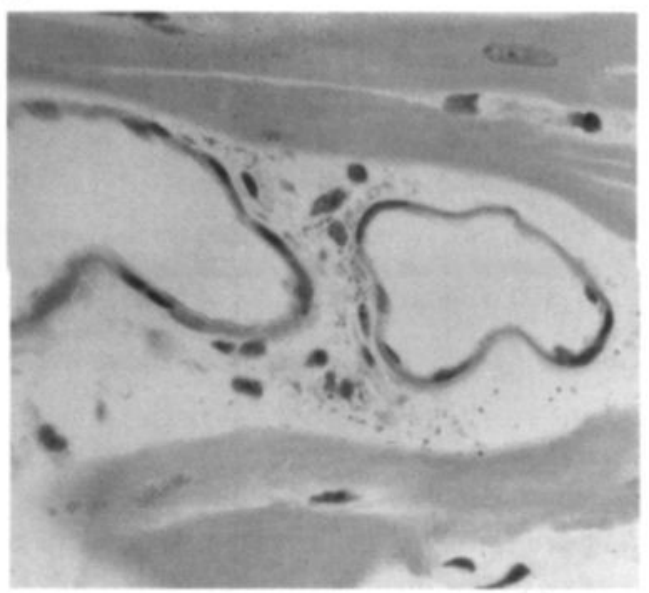

Figure 6.3: Toluidine blue staining of sections of normoxic perfused rat hearts Hearts isolated from non-sensitized and sensitized rats (See Materials and Methods) were perfused according to Langendorff. Both non-sensitized and sensitized hearts were challenged with antigen. After $20 \mathrm{~min}$, hearts were snap-frozen in dry ice-cooled isopentane. Formalin-fixed sections (4-6 $\mu \mathrm{m})$ were incubated with $0.5 \%$ toluidine blue for $2 \mathrm{~min}$. In sections from non-sensitized hearts challenged with antigen (A), mast cells showed a dense granular structure and released granules were not observed. In sensitized hearts challenged with antigen (B), a massive mast cell degranulation was observed, as indicated by the presence of numerous mast cell granules residing in the vicinity of degranulated mast cells. In these hearts, the dense granular structure of mast cells was lost.

\subsection{DISCUSSION}

In the present study the role of mast cells in ischemia/reperfusion-induced injury to cardiomyocytes was evaluated. Hearts, isolated from sensitized and non-sensitized animals, were perfused according to Langendorff. During normoxic perfusion, both sensitized and non-sensitized hearts were challenged with antigen (TNP-OVA). This procedure has been shown to specifically result in mast cell degranulation in sensitized 
hearts. ${ }^{13}$ After $20 \mathrm{~min}$, the 'mast cell-depleted' hearts were subjected to $30 \mathrm{~min}$ of global ischemia and $30 \mathrm{~min}$ of reperfusion.

Vleeming et al. ${ }^{13}$ have shown that in the present experimental model, approximately $1400 \mathrm{ng}$ of histamine is released during the first min after antigen challenge. This was followed by the release of about $350 \mathrm{ng}$ in the next two min. Thereafter, histamine release was negligible. It has been shown that in the heart, histamine is predominantly stored in mast cells. $2,8,10$ Since the total cardiac histamine content attributes to $2500 \mathrm{ng}$ (see Chapter 2), it can be calculated that in the present model, approximately $70 \%$ of the cardiac mast cells have degranulated due to antigen challenge (also see Chapter 7). This notion was confirmed when sections of sensitized hearts were incubated with toluidine blue. In sensitized hearts, antigen challenge resulted in a large proportion of degranulated mast cells, showing numerous granules residing close to and at large distances from the degranulated cells. Since antigen challenge did not result in increased $\mathrm{LDH}$ release during the normoxic period, these results indicate that a massive mast cell degranulation under normoxic conditions was not accompanied by injury to cardiomyocytes.

We observed that in sensitized hearts, antigen challenge resulted in a transient increase in CF and LVDP, which is in agreement with the results of Vleeming et al. ${ }^{13}$ It should be noted that, since in our experiments maximal CF values were already reached at about $30 \mathrm{~s}$ after antigen challenge ( $1 \mathrm{~min}$ in the study of Vleeming et al. ${ }^{13}$ ) and the first collection of coronary effluent was at $1 \mathrm{~min}$ after antigen challenge, this increase is not evident from Fig. 6.1 A. In the present experimental model, the antigenevoked increases in CF and LVDP have been shown to be absent when hearts were perfused in the presence of the $\mathrm{H}_{2}$-receptor blocker cimetidine. ${ }^{13}$ In addition, histamine dose-dependently increased CF and LVDP in non-sensitized hearts. ${ }^{13}$ Therefore, it has been proposed by these authors that the increase in CF and LVDP after antigen challenge is due to the release of histamine by mast cells. The increases in CF and LVDP were followed by a rapid decrease, reaching minimal values at 2-3 $\mathrm{min}$ after antigen challenge, and a steadily increase thereafter. Vleeming et al. ${ }^{13}$ have also shown that the decrease in CF and LVDP were abolished when hearts were perfused in the presence of the 5-lipoxygenase inhibitor AA-861 or the leukotriene antagonist FPL 55712 , indicating that leukotrienes might play an important role in cardiac anaphylaxis. In the present study, no effects of antigen challenge on CF and LVDP were observed in non-sensitized hearts, which points to the specificity of the sensitization procedure. During reperfusion, we found no significant differences in CF and LVDP between sensitized and non-sensitized hearts, indicating that it is unlikely that mast cells are involved in the effect of ischemia/reperfusion on these parameters after restoration of flow.

It was found that during reperfusion, LDH release from 'mast cell-depleted hearts', i.e., sensitized hearts challenged with antigen during normoxic perfusion, was equal to that of reperfused, non-sensitized, hearts. This suggests that it is unlikely that mast cells contribute to the extent of acute ischemia/reperfusion-induced injury to cardiomyocytes. This observation is of particular importance, since studies of other investigators have suggested that mast cells are involved in acute hypoxia/reoxygenation- 
induced injury. ${ }^{6}$ These authors have shown that in the isolated rat heart, the extent of hypoxia/reoxygenation-induced injury to cardiomyocytes (measured as the release of creatine kinase) correlated closely to the release of peroxidase (PO), a proposed marker of mast cell degranulation. The reason for the discrepancy between our results and those of Keller et al. ${ }^{6}$ are unknown, but may be due to differences in the experimental model (ischemia/reperfusion vs. hypoxia/reoxygenation, the latter resulting in an extent of injury to cardiac muscle cells which is about 10 times as much as that caused by ischemia/reperfusion), or the experimental conditions used to study the effects of mast cells on loss of cardiomyocyte integrity (use of 'mast cell depleted hearts' vs. use of PO as a marker of mast cell degranulation). This will be discussed in detail in Chapter 7.

In summary, we found that during normoxic conditions, mast cell degranulation had profound effects on coronary flow and left ventricular developed pressure. However, during reperfusion no differences in these hemodynamic parameters were observed between sensitized and non-sensitized hearts. In addition, during all phases of perfusion, LDH release from 'mast cell-depleted hearts' was not significantly different from that of reperfused, non-sensitized hearts. Therefore, the results provide no direct evidence that in the isolated rat heart, mast cells are prominently involved in acute ischemia/ reperfusion-induced injury to cardiomyocytes. Although the present experimental set-up differed at some points from the situation in vivo (absence of blood cells, no extrinsic innervation), it is tempting to speculate that mast cells are of little importance in determining the extent of acute ischemia/reperfusion-induced myocardial injury in vivo.

\subsection{REFERENCES}

1. Bergmeyer, H.U. and Bernt, E. (1974) In: Methods of Enzymatic Analysis, (Bergmeyer, H.U., ed.), Vol. 2, pp. 574-579. Weinheim: Verlag Chemie GmbH.

2. Cabanié, M. and Godfraind, T. (1988) The role of histamine in the cardiovascular system. Drugs Exptl Clin Res 14, 141-147.

3. Hearse, D.J., Maxwell, L., Saldanha, C. and Gavin, J.B. (1993) The myocardial vasculature during ischemia and reperfusion: a target for injury and protection. I Mol Cell Cardiol 25, 759-800.

4. Jennings, R.B. and Reimer, K.A. (1983) Factors involved in salvaging ischemic myocardium: effect of reperfusion of arterial blood. Circulation 68 (suppl.), 25-36.

5. Jolly, S.R., Abrams, G.D., Romson, J.L., Bailie, M.B. and Lucchesi, B.R. (1982) Effects of lodoxamide on ischemic reperfused myocardium. J Cardiovasc Pharmacol 4, 441-448.

6. Keller, A.M., Clancy, R.M., Barr, M.L., Marboe, C.C. and Cannon, P.J. (1988) Acute reoxygenation injury in the isolated rat heart: role of resident cardiac mast cells. Circ Res 63, 1044-1052.

7. Kloner, R.A., Przyklenk, K. and Whittaker, P. (1989) Deleterious effects of oxygen radicals in ischemia/reperfusion: resolved and unresolved issues. Circulation 80, 1115-1127.

8. Mannaioni, P.F., Gianella, E., Palmerani, B., Gambassi, F., Bani-Sacchi, T., Bianchi, S. and Masini, E. (1988) Free radicals as endogenous histamine releasers. Agents Actions 23, 129-142.

9. McCord, J.M. (1985) Oxygen-derived free radicals in postischemic tissue injury. N Engl J Med $312,159-163$.

10. Rydzynski, K., Kolago, B., Zaslonka, J. and Kuroczynski, W. (1988) Distribution of mast cells in human heart auricles and correlation with tissue histamine. Agents Actions 23, 273-275.

11. Shen, A.C. and Jennings, R.B. (1972) Myocardial calcium and magnesium in acute ischemic injury. Am I Pathol 67, 417-434.

12. Ufkes, J.G.R., Ottenhof, M. and Aalberse, R.C. (1983) A new method for inducing fatal, IgEmediated bronchial and cardiovascular anaphylaxis in the rat. J Pharmacol Methods 9, 175-181.

13. Vleeming, W., Rooij, H.H., Wemer, J. and Porsius, A.J. (1991) Characterization and modulation of antigen-induced effects in the isolated rat heart. J Cardiovasc Pharmacol 18, 556-565. 


\section{ICHAPTER 7}

\section{Lack of Evidence for a Role of Mast Cell Degranulation in Acute Hypoxia/Reoxygenation-induced Myocardial Injury in the Isolated Rat Heart}

This chapter will be published in:

Charles M.C.J. van Haaster, Wim Engels, Adriaan M. Duijvestijn, Paul J.M.R. Lemmens,

Gerard Hornstra and Ger J. Van der Vusse

Lack of evidence for a role mast cell degranulation in acute hypoxia/reoxygenation-

induced myocardial injury in the isolated rat heart

J. Mol. Cell. Cardiol. (Accepted for Publication) 


\subsection{ABSTRACT}

In the present study, the potential role of mast cell degranulation in acute hypoxia/reoxygenation-induced injury to cardiomyocytes in the isolated rat heart was evaluated. Histamine release was determined to delineate the extent of mast cell degranulation, whereas the release of creatine kinase (CK) and lactate dehydrogenase $(\mathrm{LDH})$ was assessed to quantitate the extent of irreversible injury to cardiomyocytes. The suitability of peroxidase (PO) as a marker for mast cell degranulation was also evaluated. Reoxygenation resulted in a release of histamine corresponding to $6.5 \pm$ $0.6 \%$ of total tissue content, whereas $L D H, C K$ and $P O$ release amounted to $30 \pm 2 \%$, $28 \pm 2 \%$ and $32 \pm 3 \%$ of their respective tissue contents. Identical perfusion in the presence of the mast cell stabilizer lodoxamide resulted in a reduced histamine release $(2.8 \pm 0.1 \%)$ of total tissue content upon reoxygenation, but the release of $L D H, C K$ or $P O$ was not influenced. Cumulative histamine release did not correlate to the amounts of $L D H, C K$ or $P O$ released. Treatment with consecutive bolus injections of the mast cell-degranulating compound 48/80 during normoxic perfusion resulted in an almost complete histamine release, whereas $P O$ release remained below detection limit. When the compound 48/80-treated hearts were subjected to hypoxia/reoxygenation, the release of $L D H, C K$ or $P O$ during reoxygenation, again, remained unchanged, whereas histamine release was negligible. Determination of PO-activity of freshly isolated cardiomyocytes demonstrated that the bulk of PO in rat hearts was located in this particular cell type. We therefore conclude that in the isolated rat heart, $P O$ release is not a specific marker of mast cell degranulation. In addition, our data provide no firm evidence that in this experimental model, mast cell degranulation contributes to a significant extent to acute hypoxia/reoxygenationinduced injury to cardiomyocytes.

\subsection{INTRODUCTION}

In the present study the role of mast cells in a model of hypoxia/reoxygenation-induced injury to cardiomyocytes was evaluated. Mast cells are predominantly located adjacent to capillaries, small arteries and venules ${ }^{6}$ and are known to represent the major repository for histamine in various tissues. ${ }^{11}$ Circulating histamine is taken up by the heart and is predominantly stored in resident mast cells and in a small non-releasable histamine pool which is not localized, but may be the adrenergic nerve terminals or vascular smooth muscle cells. ${ }^{23}$ As a consequence, the distribution of histamine in the heart closely matches the distribution of mast cells ${ }^{4,27}$ and, therefore, the release of this substance has been used as a marker to indicate the extent of mast cell degranulation in in vivo and ex vivo studies. ${ }^{17,24}$

Observations from Keller et al. have implicated mast cells in acute hypoxia/reoxygenation-induced injury in the isolated rat heart. ${ }^{18}$ One of the arguments in favour of this notion was that, during reoxygenation, the release of peroxidase (PO), which was used as a marker of mast cell degranulation, correlated closely to that of creatine kinase (CK), a marker of (irreversible) injury to cardiomyocytes. Recent 
observations in peritoneal mast cells ${ }^{26}$, however, have shed some doubt on the specificity of $\mathrm{PO}$ as marker enzyme of mast cells, which makes conclusions on the crucial role of resident mast cells in reoxygenation injury in the heart as found in earlier studies, less certain. ${ }^{18}$ In addition, we have previously found that mast cells did not contribute to the extent of acute ischemia/reperfusion-induced injury to cardiomyocytes (Chapter 6). The present study aims at elucidating in more detail the potential role of resident mast cells in acute hypoxia/reoxygenation-induced injury to cardiomyocytes in the isolated rat heart. Special attention was paid to the suitability of $\mathrm{PO}$ as marker for mast cell degranulation by comparing the release of histamine to that of PO. The release of CK and lactate dehydrogenase (LDH) were monitored as quantitative markers of irreversible injury of cardiac muscle cells.

Since the bulk of PO in the heart was located in cardiomyocytes rather than in mast cells, we conclude that this enzyme may not be used as a marker to indicate the extent of mast cell degranulation. In addition, the results indicate that in the present model, mast cell degranulation does not contribute to a significant extent to acute hypoxia/reoxygenation-induced injury to cardiomyocytes.

\subsection{MATERIALS AND METHODS}

\section{Animals}

Hearts were isolated from Lewis rats (body weight, $250-280 \mathrm{~g}$ ) obtained from the Central Animal Facility of the University of Limburg. The animals had free access to food and water.

\section{Experimental Set-up}

Hearts, isolated from heparinized rats (5000 IU/kg i.p.), were immediately mounted for perfusion by the Langendorff technique. ${ }^{19}$ Perfusion pressure was kept constant at 80 $\mathrm{mm} \mathrm{Hg}$. A thin cannula was placed in the left ventricle through the apex to register left ventricular pressure (see below). The perfusion buffer contained (in $\mathrm{mM}$ ): $\mathrm{NaCl}$ (118.0), $\mathrm{KCl}$ (4.7), $\mathrm{MgSO}_{4}$ (1.2), $\mathrm{KH}_{2} \mathrm{PO}_{4}$ (1.2), $\mathrm{NaHCO}_{3}$ (25.0) and $\mathrm{CaCl}_{2}$ (2.5). (D+)Glucose (4.0) was added when indicated. In all experiments, the final $\mathrm{pH}$ was 7.40 (range 7.35-7.45). Temperature was kept at $37^{\circ} \mathrm{C}$ throughout the experiments.

\section{Protocol}

Hearts were subjected to similar hypoxia/reoxygenation procedures as described earlier by Keller et al. ${ }^{18}$ These procedures are known to result in a high degree of injury to cardiac muscle cells. ${ }^{9,14,15}$ Briefly, hearts were subjected to 35 min of normoxic perfusion, during which period the perfusion buffer (containing glucose) was gassed with a mixture of $95 \% \mathrm{O}_{2} / 5 \% \mathrm{CO}_{2}\left(\mathrm{PO}_{2}>80 \mathrm{kPa}\right)$. Thereafter, hearts were subjected to 60 min of hypoxic perfusion, during which the perfusion buffer (without glucose) was continuously gassed with a mixture of $95 \% \mathrm{~N}_{2} / 5 \% \mathrm{CO}_{2}\left(\mathrm{PO}_{2}<5 \mathrm{kPa}\right)$. Hearts were reoxygenated for $30 \mathrm{~min}$ by perfusion with buffer without glucose, gassed with $95 \%$ $\mathrm{O}_{2} / 5 \% \mathrm{CO}_{2}$. Left ventricular diastolic and systolic pressures were continuously monitored with use of the catheter inserted into the left ventricular cavity which was 
connected to an external pressure transducer. Left ventricular developed pressure (LVDP) was calculated as the difference between left ventricular systolic and enddiastolic pressure. Heart rate was calculated by using pressure registrations. Coronary flow was measured by timed collection of the coronary effluents. When the effect of the mast cell stabilizer lodoxamide tromethamine (lodoxamide, $25 \mu \mathrm{M}$, a kind gift of the Upjohn Co., Kalamazoo, USA) was studied, this compound was continuously present in the perfusion buffer throughout the experiment. Normoxic control hearts were perfused for 125 min with buffer containing glucose and gassed with $95 \% \mathrm{O}_{2} / 5 \% \mathrm{CO}_{2}$. These hearts were also perfused in the presence or absence of lodoxamide as indicated.

In a subset of experiments, the effects of a massive mast cell degranulation on cardiomyocyte integrity during normoxia and subsequent hypoxia/reoxygenation were studied. Therefore, during normoxic perfusion, hearts were treated with three consecutive bolus injections of $50 \mu \mathrm{g}$ of compound $48 / 80$ (dissolved in $0.5 \mathrm{ml}$ of perfusion buffer). These hearts were either freeze-clamped at the end of normoxic perfusion $(n=4)$ or were subjected to hypoxia/reoxygenation $(n=4)$ and freeze-clamped thereafter (see below).

\section{Collection of Tissue and Effluent Samples}

At the end of the experiment, atria were rapidly removed from the ventricular tissue and hearts were immediately freeze-clamped with the use of liquid nitrogen-cooled aluminum tongs. Tissue samples were stored at $-70^{\circ} \mathrm{C}$.

Coronary effluents were sampled during the last $15 \mathrm{~min}$ of normoxic perfusion (three periods of $5 \mathrm{~min}$ ), during $60 \mathrm{~min}$ of hypoxic perfusion (initially two periods of $5 \mathrm{~min}$, followed by five periods of $10 \mathrm{~min}$ ) and during $30 \mathrm{~min}$ of reoxygenation (ten periods of 3 $\mathrm{min})$. Bovine serum albumin $(3 \%, \mathrm{w} / \mathrm{v})$ was added to the coronary effluent samples in order to improve enzyme stability.

When the effect of compound $48 / 80$ on the release of myocardial enzymes and histamine was studied, hearts were treated with three consecutive bolus injections with 5 min intervals, starting at $15 \mathrm{~min}$ before hypoxic perfusion. Coronary effluent samples were collected during these three phases and during one $5 \mathrm{~min}$ interval before the first treatment with compound 48/80. Thereafter, during hypoxia and subsequent reoxygenation, coronary effluents were collected as described above.

\section{Biochemical Analysis of Cardiac Tissue}

\section{LDH, PO and Histamine}

Parts of the frozen tissue $(400-500 \mathrm{mg}$ ) were pulverized with a stainless steel pestle and an aluminum mortar, both cooled to the temperature of liquid nitrogen. The pulverized tissue was brought into ice-cold homogenization buffer $(50 \mathrm{mM} \mathrm{Tris.} \mathrm{HCl} / 50$ $\mathrm{mM} \mathrm{NaCl}, \mathrm{pH} 8.5)$ to a final concentration of $5 \%(\mathrm{w} / \mathrm{v})$. After homogenization and sonication, a sample was withdrawn for the determination of histamine (see below). The remaining suspension was centrifuged at $48,000 \times g$ for $15 \mathrm{~min}\left(4^{\circ} \mathrm{C}\right)$. Supernatants were collected for the determination of $\mathrm{PO}$ and $\mathrm{LDH}$-activity. Biochemical analysis of the remaining cell-pellet demonstrated that the procedure resulted in a complete 
recovery of tissue enzyme activity in the supernatant fraction (data not shown). PO and $\mathrm{LDH}$-activity were determined spectrophotometrically using a centrifugal analyzer (Cobas Bio System). LDH-activity was determined according to Bergmeyer et al. ${ }^{3}$ POactivity was determined by a commercially available kit (Kirkegaard \& Perry Laboratories, USA). Horseradish peroxidase (Boehringer Mannheim $\mathrm{GmbH}$, Mannheim, FRG) was used as $\mathrm{PO}$ reference standard. $\mathrm{LDH}$-activity was determined at $25^{\circ} \mathrm{C}(\mathrm{pH} \mathrm{7.4)}$ and POactivity at $37{ }^{\circ} \mathrm{C}(\mathrm{pH}$ 5.3). Histamine content was determined by High Performance Liquid Chromatography as described in Chapter 2.

\section{Creatine Kinase}

For the determination of CK-activity in cardiac tissue, aliquots of the frozen tissue were treated as described above, except that mercapto-ethanol $(0.0002 \%, \mathrm{v} / \mathrm{v})$ was added to the homogenization buffer in order to protect CK from inactivation. CK-activity (determined at $25^{\circ} \mathrm{C}, \mathrm{pH} 7.4$ ) was determined spectrophotometrically with a commercially available CK-NAC test kit (Merck, Darmstadt, FRG) using the Cobas Bio Autoanalyzer.

\section{Biochemical Analysis of Coronary Effluents}

The activities of $\mathrm{LDH}, \mathrm{CK}$ and $\mathrm{PO}$ were determined in freshly obtained coronary effluent samples, as described above, on the same day of the experiment. Samples for analysis of the histamine content were stored at $-70^{\circ} \mathrm{C}$.

\section{Histochemistry}

Hearts for histochemistry were subjected to $20 \mathrm{~min}$ of normoxic perfusion. Thereafter, they were snap-frozen in dry ice-cooled isopentane and stored at $-70{ }^{\circ} \mathrm{C}$. For histochemistry, 4-6 $\mu \mathrm{m}$ thick sections were cut and air-dried for $60 \mathrm{~min}$. Sections were incubated with either $0 \%, 0.06 \%$ or $0.15 \% \mathrm{H}_{2} \mathrm{O}_{2}$, respectively, in the presence of $0.05 \%$ diaminobenzidine (DAB) in phosphate-buffered saline (PBS), $\mathrm{pH} 5.3$, which is nearly the $\mathrm{pH}$ optimum of mast cell and leukocyte peroxidases. ${ }^{16}$ In order to compare our results to those of Keller et al. ${ }^{18}$, who performed the analyses at $\mathrm{pH} 6.3$, additional sections were stained with DAB in PBS, $\mathrm{pH}$ 6.3. Slides were routinely dehydrated and coverslipped.

\section{Isolation of Cardiomyocytes and Determination of $P O$ and $L D H$ activity}

Cardiomyocytes were freshly isolated from adult Lewis rats $(n=4)$ according to Linssen et al. $^{20}$ and were resuspended in homogenization buffer. After homogenization and sonication, a sample was withdrawn for determination of the protein content. ${ }^{21}$ Thereafter, samples were centrifuged at $48,000 \times \mathrm{g}$ for $15 \mathrm{~min}\left(4^{\circ} \mathrm{C}\right)$ and supernatants were collected. Histamine was absent in the supernatants, indicating that mast cells did not contaminate the cardiomyocyte suspension (data not shown). PO and LDH-activities were determined in the supernatants and were expressed as $\mathrm{mU} / \mathrm{mg}$ cellular protein and $\mathrm{U} / \mathrm{mg}$ cellular protein, respectively. 


\section{Normalization of the Data}

Dry weights of cardiac tissue were determined by freeze-drying aliquots of the frozen tissue overnight. Tissue contents of LDH and CK were expressed as $\mathrm{U} / \mathrm{g}$ dry weight. Tissue content of $\mathrm{PO}$ was expressed as $\mathrm{mU} / \mathrm{g}$ dry weight and histamine content as $\mathrm{ng} / \mathrm{g}$ dry weight. Whenever comparison of cardiac tissue data and coronary release data was required, we assumed that the release per heart was equivalent to the release per gram wet weight, since hearts of rats of this age weigh approximately $1 \mathrm{~g}$. ${ }^{5}$ For conversion of coronary release per gram wet weight to release per gram dry weight, an average factor of 5 was applied (based on a percentage dry weight of approximately $20 \%$ of hearts freeze-clamped immediately after removal from the body). Coronary flow was expressed as $\mathrm{ml} / \mathrm{min} . \mathrm{g}$ dry weight, also using an average conversion factor of 5 .

\section{Statistical Analysis}

Data are presented as mean values \pm SEM. Comparisons between groups were made using an analysis of variance. The relation between variables was determined by linear regression analysis. Values of $\mathrm{P} \leq 0.05$ were considered to be statistically significant.

\subsection{RESULTS}

\section{Hemodynamic Parameters}

After $35 \mathrm{~min}$ of normoxic perfusion, hearts were subjected to $60 \mathrm{~min}$ of hypoxic perfusion and subsequently to $30 \mathrm{~min}$ of reoxygenation (hypoxia/ reoxygenation), both in the presence or absence of lodoxamide. The values of coronary flow, heart rate, left ventricular developed pressure (LVDP) at the end of the normoxic perfusion phase (35 $\mathrm{min})$, hypoxic perfusion phase $(95 \mathrm{~min})$ and reoxygenation phase $(125 \mathrm{~min})$ are presented in Table 7.1.

Table 7.1: Hemodynamic Parameters

\begin{tabular}{|c|c|c|c|c|c|c|}
\hline Treatment & $\mathrm{n}$ & $\begin{array}{l}\text { Time } \\
(\min )\end{array}$ & Phase & $\begin{array}{l}\text { Heart Rate } \\
\text { (Beats/min) }\end{array}$ & $\begin{array}{c}\text { LVDP } \\
(\mathrm{mm} \mathrm{Hg})\end{array}$ & $\begin{array}{l}\text { Coronary Flow } \\
\text { (ml/min.g dry w) }\end{array}$ \\
\hline \multirow[t]{3}{*}{ Control } & 7 & 35 & Normoxia & $244 \pm 11$ & $80 \pm 3$ & $42 \pm 4$ \\
\hline & & 95 & Hypoxia & 0 & 0 & $53 \pm 5$ \\
\hline & & 125 & Reoxygenation & 0 & 0 & $41 \pm 5$ \\
\hline \multirow[t]{3}{*}{ Lodoxamide } & 6 & 35 & Normoxia & $262 \pm 14$ & $80 \pm 1$ & $40 \pm 2$ \\
\hline & & 95 & Hypoxia & 0 & 0 & $58 \pm 3$ \\
\hline & & 125 & Reoxygenation & 0 & 0 & $49 \pm 3$ \\
\hline
\end{tabular}

After 35 min of normoxic perfusion, hearts were subjected to 60 min of hypoxic perfusion, followed by $30 \mathrm{~min}$ of reoxygenation in the presence or absence of $25 \mu \mathrm{M}$ lodoxamide, as indicated. Heart Rate, Left Ventricular Developed Pressure (LVDP) and Coronary Flow at the end of the normoxic perfusion phase $(35 \mathrm{~min})$, hypoxic perfusion phase $(95 \mathrm{~min})$ and at the end of the reoxygenation phase (125 min) are presented. Data are represented as mean values \pm SEM. No significant differences were observed between hearts perfused in the absence (control) or presence of lodoxamide; $n$ refers to the number of hearts per group. 
In both groups, i.e., perfusion in the presence or absence of lodoxamide, hypoxia resulted in a transient increase in the coronary flow during the first 5 min of hypoxic perfusion, which rapidly decreased thereafter, reaching a relatively constant level of about $150 \%$ of normoxic coronary flow after $20 \mathrm{~min}$ (data not shown). After 6 min of hypoxia, heart rate was zero and both diastolic and systolic pressure were equal to the perfusion pressure of $80 \mathrm{~mm} \mathrm{Hg}$. Coronary flow decreased during the first $6 \mathrm{~min}$ of reoxygenation and was followed by a recovery phase which tended to be higher in lodoxamide-perfused hearts. Reoxygenation did not result in improvements in heart rate or LVDP in either group.

\section{Release of Enzymes and Histamine into Coronary Effluents: Relation to Cardiac Tissue} Content

Both in the presence and absence of lodoxamide, cumulative release of LDH $(12 \pm 2$ $\mathrm{U} / \mathrm{g}$ dry weight and $12 \pm 3 \mathrm{U} / \mathrm{g}$ dry weight, respectively) and CK (18 $\pm 3 \mathrm{U} / \mathrm{g}$ dry weight and $19 \pm 4 \mathrm{U} / \mathrm{g}$ dry weight, respectively) from hearts subjected to $125 \mathrm{~min}$ of normoxic perfusion was very low. Total normoxic tissue contents of LDH and CK amounted to $1916 \pm 71 \mathrm{U} / \mathrm{g}$ dry weight and $3172 \pm 90 \mathrm{U} / \mathrm{g}$ dry weight, respectively, and were not influenced by lodoxamide treatment $(1904 \pm 75 \mathrm{U} / \mathrm{g}$ dry weight and $3148 \pm 90 \mathrm{U} / \mathrm{g}$ dry weight, respectively). Cumulative $\mathrm{PO}$ and histamine release under normoxic conditions remained below detection limits $(<21 \mathrm{mU} / \mathrm{g}$ dry weight and $<63 \mathrm{ng} / \mathrm{g}$ dry weight, respectively). Tissue $\mathrm{PO}$ and histamine contents amounted to $912 \pm 28 \mathrm{mU} / \mathrm{g}$ dry weight and $12984 \pm 606 \mathrm{ng} / \mathrm{g}$ dry weight, respectively, and were not influenced by treatment with lodoxamide $(896 \pm 39 \mathrm{mU} / \mathrm{g}$ dry weight and $13030 \pm 716 \mathrm{ng} / \mathrm{g}$ dry weight, respectively). Similar results were obtained when normoxic control hearts were perfused without glucose during the last $95 \mathrm{~min}$ of perfusion (data not shown).

Hypoxia resulted in limited mast cell degranulation, as indicated by an increased histamine release $(259 \pm 29 \mathrm{ng} / \mathrm{g}$ dry weight), which was almost absent when lodoxamide was present ( $25 \pm 14 \mathrm{ng} / \mathrm{g}$ dry weight) (Table 7.2). In contrast, PO release remained below detection limit, both in the presence or absence of lodoxamide. Hypoxia resulted in a small loss of cardiomyocyte integrity, as indicated by an increased release of $\mathrm{LDH}$ ( $36 \pm 3 \mathrm{U} / \mathrm{g}$ dry weight) and CK (51 $\pm 4 \mathrm{U} / \mathrm{g}$ dry weight) during this period (Table 7.2). The release of $\mathrm{LDH}$ or CK were not influenced by the presence of lodoxamide. Enzyme and histamine release were highest during the first five $\mathrm{min}$ of hypoxia and rapidly decreased thereafter (data not shown).

Reoxygenation resulted in an increased histamine release (845 $\pm 72 \mathrm{ng} / \mathrm{g}$ dry weight), which corresponds to a cumulative loss of $6.5 \pm 0.6 \%$ of total tissue content during this phase. Lodoxamide significantly reduced histamine release during reoxygenation $(2.8 \pm 0.1 \%)$, pointing to the stabilizing effects of this compound on mast cell membranes. Irrespective of the presence of lodoxamide, reoxygenation resulted in a high degree of injury to cardiomyocytes, as indicated by the loss of $30 \pm 2 \%$ and $28 \pm$ $2 \%$ of the tissue contents of LDH and CK, respectively. Similarly, PO-loss was high, irrespective whether lodoxamide was present $(32 \pm 1 \%)$ or not $(32 \pm 3 \%)$. Reoxygenation resulted in an immediate release of enzymes and histamine, with values highest during the first three min of reoxygenation (data not shown). 
Table 7.2: Release of Enzymes and Histamine during Normoxia, Hypoxia and Reoxygenation; Effects of Lodoxamide

\begin{tabular}{|c|c|c|c|c|c|c|c|c|}
\hline Variable ${ }^{1}$ & Lodoxamide $^{2}$ & $n^{3}$ & Normoxia ${ }^{4}$ & Hypoxia 5 & Reoxygenation 6 & Cumulative loss 7 & Tissue content ${ }^{8}$ & $\begin{array}{l}\% \text { Loss during } \\
\text { Reoxygenation }\end{array}$ \\
\hline \multirow[t]{2}{*}{$\mathrm{LDH}$} & - & 7 & $3 \pm 1$ & $36 \pm 3$ & $571 \pm 43$ & $610 \pm 45$ & $1259 \pm 61$ & $30 \pm 2$ \\
\hline & + & 6 & $3 \pm 1$ & $41 \pm 2$ & $613 \pm 25$ & $657 \pm 27$ & $1275 \pm 70$ & $32 \pm 1$ \\
\hline \multirow[t]{2}{*}{ CK } & - & 7 & $3 \pm 1$ & $51 \pm 4$ & $895 \pm 71$ & $950 \pm 71$ & $2336 \pm 102$ & $28 \pm 2$ \\
\hline & + & 6 & $4 \pm 1$ & $56 \pm 5$ & $946 \pm 43$ & $1006 \pm 47$ & $2389 \pm 153$ & $30 \pm 1$ \\
\hline \multirow[t]{2}{*}{ PO } & - & 7 & $<3$ & $<12$ & $293 \pm 27$ & $293 \pm 27$ & $593 \pm 22$ & $32 \pm 3$ \\
\hline & + & 6 & $<3$ & $<12$ & $290 \pm 12$ & $290 \pm 12$ & $584 \pm 26$ & $32 \pm 1$ \\
\hline \multirow[t]{2}{*}{ Histamine } & - & 7 & $<9$ & $259 \pm 29$ & $845 \pm 72$ & $1104 \pm 75$ & $11825 \pm 586$ & $6.5 \pm 0.6$ \\
\hline & + & 6 & $<9$ & $25 \pm 14^{\circ}$ & $371 \pm 16^{\circ}$ & $395 \pm 24^{\circ}$ & $12161 \pm 736$ & $2.8 \pm 0.1^{\circ}$ \\
\hline
\end{tabular}

After $35 \mathrm{~min}$ of normoxic perfusion, hearts were subjected to 60 min of hypoxic perfusion, followed by 30 min of reoxygenation $L D H, C K, P O$ refer to lactate dehydrogenase, creatine kinase and peroxidase activity, respectively

Lodoxamide $\%+$ refers to absence or presence of $25 \mu \mathrm{M}$ lodoxamide in the perfusion buffer throughout the experiment

$n$ refers to the number of hearts per group

4,5,6 Cumulative release of enzymes or histamine in coronary effluents during Normoxia (35 min), Hypoxia (60 min) or Reoxygenation (30 min). $\mathrm{LDH}$ and $\mathrm{CK}$ release are expressed as $\mathrm{U} / \mathrm{g}$ dry weight, $P O$ release as $\mathrm{mU} / \mathrm{g}$ dry weight and histamine release as ng/g dry weight

7 Cumulative loss of enzymes or histamine during the total perfusion period

8 Enzyme activity/histamine content as measured in homogenates of hearts freeze-clamped at the end of the experiment: $L D H$ and CK are expressed as $\mathrm{U} / \mathrm{g}$ dry weight, $P O$ as $\mathrm{mU} / \mathrm{g}$ dry weight and histamine as $\mathrm{ng} / \mathrm{g}$ dry weight

- significantly different ( $P \leq 0.05$ ) from corresponding group perfused in the absence of lodoxamide 
Release of PO and Histamine into Coronary Effluents during Reoxygenation: Relation to irreversible Loss of Cardiomyocyte Integrity

In order to delineate a possible relation between mast cell degranulation and irreversible injury to cardiomyocytes during reoxygenation, cumulative release of histamine of each individual heart was compared to that of LDH and CK (Fig. 7.1). In addition, the cumulative release of $\mathrm{PO}$ of each heart was compared to that of $\mathrm{LDH}$ and CK. LDH release correlated closely $(r=0.95)$ to the release of CK (Fig. 7.1A), indicating simultaneous loss of these enzymes from cardiomyocytes into the extracellular compartment. Similar results were obtained by correlating PO release to the extent of injury to cardiomyocytes, assessed as the release of LDH (Fig. 7.1B, r=0.92) or CK (Fig. 7.1C, $r=0.92$ ). In contrast, no correlation was observed between the release of histamine and that of $\mathrm{LDH}$ (Fig. 7.1D, r=0.07) or CK (Fig. 7.1E, $r=0.06$ ), indicating that mast cell degranulation is not quantitatively related to the extent of injury to cardiomyocytes. Furthermore, the observation that histamine release did not correlate to PO release during reoxygenation (Fig. $7.1 \mathrm{~F}, \mathrm{r}=0.23$ ) indicates that $\mathrm{PO}$ is not a suitable marker to indicate the extent of mast cell degranulation.

The Effect of Compound 48/80 on Myocardial Enzyme and Histamine Release during Normoxic Perfusion

In order to gain additional insight into the suitability of PO as marker of mast cell degranulation, hearts $(n=4)$ were treated with three consecutive bolus injections of the mast cell-degranulating agent compound $48 / 80$ during the normoxic perfusion period. During the $5 \mathrm{~min}$ interval before the first treatment, histamine and $\mathrm{PO}$ release were below detection limits $(<1.0 \mathrm{mU} / \mathrm{g}$ dry weight and $<3.0 \mathrm{ng} / \mathrm{g}$ dry weight, respectively). The first bolus injection of compound $48 / 80$ resulted in a massive mast cell degranulation, as indicated by the release of $9010 \pm 300 \mathrm{ng}$ histamine/g dry weight during the first $5 \mathrm{~min}$ after stimulation, which corresponds with $70 \pm 3 \%$ of total cardiac histamine. In contrast, PO release remained below the detection limit during this period ( $<3 \mathrm{ng} / \mathrm{g}$ dry weight). The majority of the remaining cardiac histamine could be released by another bolus injection of compound 48/80 (3215 $\pm 115 \mathrm{ng}$ histamine/g dry weight). The third bolus injection resulted in only a marginal histamine release (255 \pm $10 \mathrm{ng} / \mathrm{g}$ dry weight). Also after the second and third compound 48/80 treatment, PO release remained below detection limit. Analysis of the histamine content of the hearts showed that the bulk of the cardiac histamine was released by this protocol, the nonreleasable histamine pool being $390 \pm 20 \mathrm{ng} / \mathrm{g}$ dry weight, i.e., about $3 \%$ of total cardiac histamine pool, whereas the PO content ( $890 \pm 40 \mathrm{mU} / \mathrm{g}$ dry weight) was equal to that of untreated, normoxic perfused hearts $(912 \pm 28 \mathrm{mU} / \mathrm{g}$ dry weight).

To investigate a possible detrimental effect of mast cell degranulation on cardiomyocyte integrity during normoxic perfusion, we compared the release of histamine to that of $\mathrm{LDH}$. Before treatment with compound $48 / 80, \mathrm{LDH}$ release was low $(0.90 \pm 0.1 \mathrm{U} / 5 \mathrm{~min} \cdot \mathrm{g}$ dry weight). Despite a massive mast cell degranulation after the first bolus injection with compound $48 / 80$, the release of LDH into coronary effluents was not increased $(0.92 \pm 0.10 \mathrm{U} / 5 \mathrm{~min} \cdot \mathrm{g}$ dry weight), indicating that under normoxic conditions mast cell degranulation does not affect the integrity of 
cardiomyocytes. Treatment with two consecutive bolus injections of compound $48 / 80$ also did not result in increased LDH release.
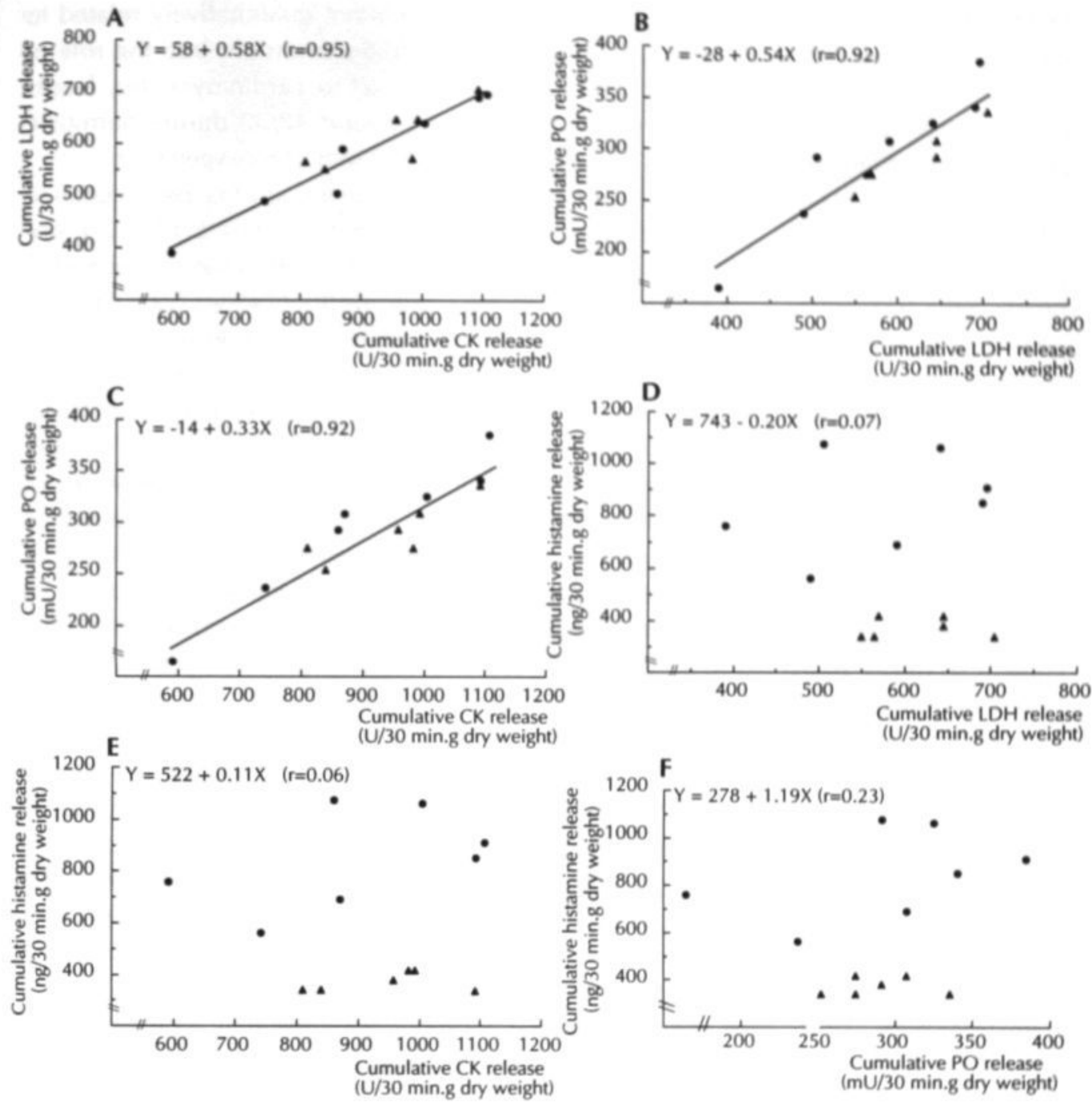

Figure. 7.1: Relationship between the release of markers of injury to cardiomyocytes and of mast cell degranulation during reoxygenation

The cumulative release of $\mathrm{LDH}$ of each individual heart during reoxygenation was plotted against the cumulative release of CK (A). Similarly, cumulative PO release of each heart was plotted against the cumulative LDH or CK release (B, C). Cumulative histamine release during reoxygenation was also plotted against cumulative $L D H$ release (D), CK release (E) or PO release (F). Cumulative enzyme or histamine release of hearts perfused in the presence or absence of the mast cell stabilizer lodoxamide $(25 \mu \mathrm{M})$ are indicated with closed triangles ( $\mathbf{\Delta})$ or closed circles $(\bullet)$ ), respectively. 
Pretreatment with Compound 48/80 during Normoxic Perfusion: Influence on Hypoxia/Reoxygenation-induced Injury to Cardiomyocytes

Thus far, the results indicate that the bulk of cardiac mast cells has degranulated after treatment with three consecutive bolus injections of compound $48 / 80$ and that the extent of mast cell degranulation during reoxygenation is not quantitatively related to the loss of cardiomyocyte integrity. In order to gain additional insight into the role of mast cell degranulation in hypoxia/reoxygenation-induced to cardiomyocytes, hearts pretreated with the mast cell-degranulating agent compound $48 / 80$ during normoxic perfusion, were also subjected to $60 \mathrm{~min}$ of hypoxia and $30 \mathrm{~min}$ of reoxygenation.

The cumulative release of $\mathrm{LDH}, \mathrm{CK}$ and $\mathrm{PO}$ of these hearts during reoxygenation attributed to $603 \pm 25 \mathrm{U} / \mathrm{g}$ dry weight, $923 \mathrm{U} / \mathrm{g}$ dry weight and $279 \pm 10 \mathrm{mU} / \mathrm{g}$ dry weight, respectively. These values were not significantly different from those observed in hearts which were not pretreated with compound 48/80 (Table 7.2). Due to pretreatment with compound $48 / 80$ during normoxic perfusion, resulting in an acute and in a severe depletion of the endogenous histamine pool, histamine release during reoxygenation remained below detection limit $(<18 \mathrm{ng} / \mathrm{g}$ dry weight). The tissue contents of $\mathrm{LDH}, \mathrm{CK}$ and $\mathrm{PO}$ in these hearts decreased to $1265 \pm 65 \mathrm{U} / \mathrm{g}$ dry weight, $2369 \pm 123 \mathrm{U} / \mathrm{g}$ dry weight and $604 \mathrm{ng} / \mathrm{g}$ dry weight, respectively. These values were not significantly different from the corresponding content of reoxygenated hearts which were not pretreated with compound 48/80. Moreover, histamine content of compound $48 / 80$ pretreated hearts subjected to hypoxia/reoxygenation amounted to $400 \pm 20 \mathrm{ng} / \mathrm{g}$ dry weight. This value was not significantly different from the histamine content of hearts subjected to a similar pretreatment with compound $48 / 80$ but which were freeze-clamped just before hypoxia (see above).

\section{Histochemical Determination of PO in Cardiac Tissue}

Since the above mentioned findings strongly suggested the presence of $\mathrm{PO}$ in cardiomyocytes, we histochemically determined the activity of this enzyme in sections of normoxic perfused hearts. A photograph of a representative histochemical localization of $\mathrm{PO}$ in cardiac tissue is shown in Fig. 7.2. In control incubations (i.e., in the absence of $\mathrm{H}_{2} \mathrm{O}_{2}$ ), staining of cardiomyocytes and mast cells was very vague and comparable to that of the interstitial space (A). In the presence of $0.15 \% \mathrm{H}_{2} \mathrm{O}_{2}, \mathrm{PO}$ staining of both cardiac mast cells and cardiomyocytes was significantly increased. Mast cells stained heavily for PO-activity (B), whereas cardiomyocytes stained light and diffuse (C). PO-staining of both mast cells and cardiomyocytes was significantly less marked when the lower concentration of $0.06 \% \mathrm{H}_{2} \mathrm{O}_{2}$ was used (data not shown). In order to correlate these findings to those of our experiments (i.e., determination of PO-activity in coronary effluents and heart homogenates at $\mathrm{pH} 5.3$ ), additional sections were stained at $\mathrm{pH}$ 5.3. The results were similar to those observed at $\mathrm{pH} 6.3$ : an intense staining of mast cells and a light and diffuse staining of cardiomyocytes which were both increased at elevated $\mathrm{H}_{2} \mathrm{O}_{2}$ concentrations. 


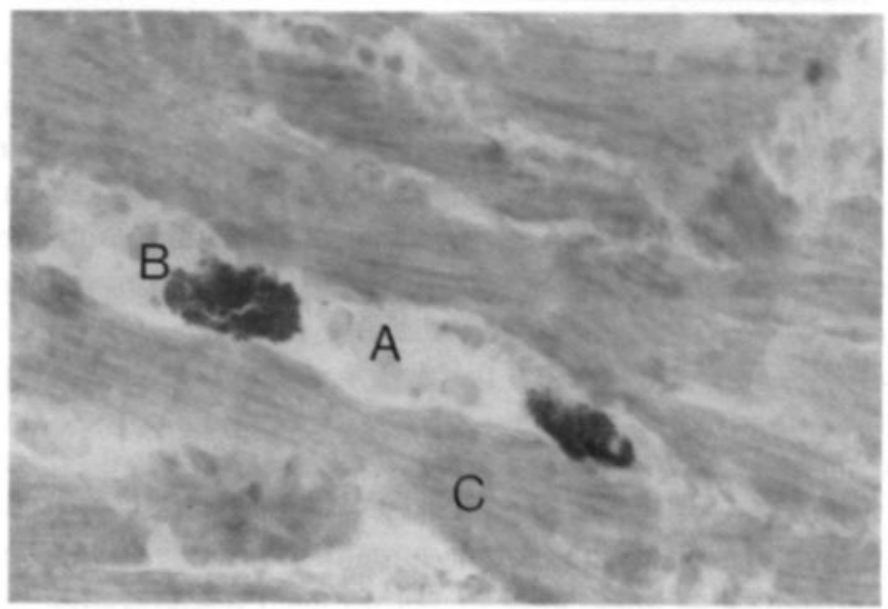

Figure 7.2: Histochemical detection of peroxidase-activity in rat heart

Sections of normoxic-perfused rat hearts $(6 \mu \mathrm{m})$ were incubated with $0.05 \% \mathrm{DAB}$ in phosphate-buffered saline, $\mathrm{PH} 6.3$ in the presence of $0.15 \% \mathrm{H}_{2} \mathrm{O}_{2}$ (see Materials and Methods). PO-activity was detected as a brown precipitate. (A), (B) and (C) refer to interstitial space, cardiac mast cell and cardiomyocytes, respectively.

\section{Biochemical Analysis of Isolated Cardiomyocytes}

To estimate the percent contribution of cardiomyocyte PO to total cardiac PO, the activity of this enzyme was assessed quantitatively in freshly isolated cardiomyocytes. Biochemical analysis demonstrated that PO-activity of these cells was $1.19 \pm 0.20$ $\mathrm{mU} / \mathrm{mg}$ protein (Table 7.3). It was calculated that the percent contribution of cardiomyocyte PO to total cardiac PO was about $90 \%$. Similarly, it was calculated that the vast majority of the cardiac LDH-content is present in cardiomyocytes (about 96\%), which allows for the use of this enzyme as marker of loss of cardiomyocyte integrity.

Table 7.3: Estimation of the Percent Contribution of Cardiomyocyte (CMC) Enzyme Content to Total Heart Content

\begin{tabular}{|c|c|c|c|c|}
\hline Enzyme $^{1}$ & $\begin{array}{l}\text { Activity in isolated } \\
\text { cardiomyocytes } \\
\text { (U/mg protein) } \\
\text { (measured) }\end{array}$ & $\begin{array}{l}\text { Activity per gram } \\
\text { cardiac tissue } \\
\text { (U/g wet weight) } \\
\text { (calculated) }{ }^{2}\end{array}$ & $\begin{array}{l}\text { Activity per gram } \\
\text { cardiac tissue } \\
\text { (U/g wet weight) } \\
\text { (measured) }^{3}\end{array}$ & $\begin{array}{l}\text { Contribution of } \\
\text { CMC to total } \\
\text { cardiac content } \\
(\%) \\
\text { (calculated) }\end{array}$ \\
\hline LDH & $2.73 \pm 0.31$ & $368 \pm 42$ & $383 \pm 14$ & $96 \pm 11$ \\
\hline PO & $1.19 \pm 0.20\left(\cdot 10^{-3}\right)$ & $161 \pm 27\left(\cdot 10^{-3}\right)$ & $182 \pm 6\left(\cdot 10^{-3}\right)$ & $90 \pm 15$ \\
\hline
\end{tabular}

$1 \mathrm{LDH}$ and PO refer to lactate dehydrogenase and peroxidase-activity, respectively

2 Assumptions: (a) contribution of other cell types (endothelial cells, fibroblasts, mast cells etc.) can be neglected (b) 1 gram of cardiac tissue corresponds to $1 \mathrm{ml}$ and (c) since cardiomyocytes occupy more than $90 \%$ of the total cellular volume of the heart', the protein content of cardiomyocytes (CMC) constitutes the bulk of the protein present in the heart (about $150 \mathrm{mg} / \mathrm{g}$ wet weight)

3 For the conversion of $\mathrm{LDH}$ or PO-content per gram dry weight (Table 7.2) to the respective contents per gram wet weight, an average wet/dry weight ratio of 5 was used 


\subsection{DISCUSSION}

In the present study, the role of mast cell degranulation in acute hypoxia/reoxygenationinduced injury to cardiomyocytes was evaluated. This model is known to result in a relatively high degree of injury to cardiomyocytes. $9,14,15$ Special attention was paid to the suitability of $\mathrm{PO}$ release as a marker of mast cell degranulation, which has previously been suggested to be a specific marker for this cell type. ${ }^{18}$

Several lines of evidence suggested that in the isolated rat heart, the release of PO was not a suitable marker to quantitate the extent of mast cell degranulation: (a) the release of histamine during reoxygenation did not correlate to that of $\mathrm{PO}$, (b) treatment of hearts with the mast cell-degranulating agent compound 48/80 during normoxic perfusion resulted in the release of the bulk of cardiac histamine, but the release of PO remained below detection limit, and (c) perfusion in the presence of the mast cell stabilizer lodoxamide significantly reduced histamine release during reoxygenation, whereas PO release was not influenced. The observation that PO was released in concert with the myocardial enzymes LDH and CK suggested the presence of PO in cardiomyocytes. This notion was confirmed when sections of normoxic perfused hearts were stained with DAB. It should be realized, however, that even if PO is present in cardiomyocytes at a relatively low concentration, the contribution of cardiomyocyte PO to total heart PO would most likely be much greater than mast cell-derived PO, since the latter cells are much smaller and far less in number. For instance, if one assumes that a heart of $1 \mathrm{gram}$ equals $1 \mathrm{ml}$, that mast cells have an average diameter of $10 \mu \mathrm{m}$ and a rat heart contains about $10^{6}$ mast cells per heart (based on morphometric data from Rakusan et al. ${ }^{25}$ and unpublished data from our own laboratory), it can be calculated that approximately $0.05 \%$ of the total cardiac volume is occupied by mast cells. Anversa et al. ${ }^{1}$ measured the relative space-distribution in the heart and found that approximately $60 \%$ of the total volume of the heart was occupied by cells, which implies that mast cells occupy approximately $0.08 \%$ of the total cellular volume of the heart. Therefore, even if one assumes that the PO-activity of mast cells is 10 times as much as that in cardiomyocytes, this activity is restricted to $<1 \%$ of the total cellular volume of the heart. Since about $90 \%$ of the total cellular volume of the heart is occupied by cardiomyocytes, the PO-content of these cells, although relatively low, may account for the bulk of PO-activity present in the heart. This notion was confirmed when we estimated the percent contribution of cardiomyocyte PO to total cardiac PO, which was found to be about $90 \%$. The presence of PO in cardiomyocytes suggests a role of this enzyme in this particular cell type. Although the specific role of PO in cardiomyocytes was not elucidated in full detail, the enzyme in these cells is most likely involved in scavenging endogenously produced $\mathrm{H}_{2} \mathrm{O}_{2}$.

Our results did not provide evidence for a role of mast cells in acute hypoxia/reoxygenation-induced injury to cardiomyocytes: (a) we observed no correlation between the release of histamine and the release of $\mathrm{LDH}$ or CK during reoxygenation, (b) when hearts were perfused in the presence of lodoxamide, histamine release during reoxygenation was significantly reduced, but the release of $\mathrm{LDH}$ or CK remained unchanged, (c) during reoxygenation, the release of $\mathrm{LDH}, \mathrm{CK}$ or PO from hearts in which 
the majority of mast cells had degranulated due to treatment with compound $48 / 80$ during normoxic perfusion (i.e., 'mast cell-depleted hearts'), was identical to that of nontreated, control hearts. These results strengthen our earlier notion (Chapter 6) that, most probably, mast cells are of minor importance in mediating the extent of acute ischemia/reperfusion-induced injury to cardiomyocytes in vivo. However, since mast cells may potentially release a variety of proinflammatory substances, such as tumor necrosis factor $\alpha($ TNF $\alpha)$ and various interleukins ${ }^{10,12}$, these cells may be involved in longer-term effects of ischemia/reperfusion, such as the infiltration of leukocytes into the tissue. The infiltration of these cells into previously ischemic myocardial tissue is known to play an important role in the development of myocardial injury following ischemia/reperfusion. $2,7,22$ This phenomenon may be due to the fact that leukocytes (especially neutrophils) release a variety of harmful substances, such as hydrogen peroxide and proteases, which may directly injure cardiac muscle cells. ${ }^{8}$ The possible role of mast cells in leukocyte-adhesion process will be discussed in Chapter 8 .

In the present study we have focused on the potential role of mast cell degranulation in irreversible injury to cardiomyocytes. Damage of other structures in the heart, such as the extracellular matrix, might have occurred during acute hypoxia/reoxygenation. Studies of Gruber et al. ${ }^{13}$ have suggested that products released from mast cells, such as tryptase, may affect the integrity of the extracellular matrix by virtue of its direct action on glycoproteins. Therefore, it cannot be excluded that degranulation of mast cells during acute hypoxia/reoxygenation contributes to damage of the extracellular matrix, if any, in the affected heart. However, acute damage inflicted upon cardiomyocytes seems not to be influenced by resident mast cells.

\subsection{REFERENCES}

1. Anversa, P., Olivetti, G., Melissari, M. and Loud, V. (1980) Stereological measurement of cellular and subcellular hypertrophy and hyperplasia in the papillary muscle of adult rat. J Mol Cell Cardiol 12, 781-795.

2. Bednar, M., Smith, B., Pinto, A. and Mullane, K.M. (1985) Nafazatrom-induced salvage of ischemic myocardium in anesthetized dogs is mediated through inhibition of neutrophil function. Circ Res 57, 131-141.

3. Bergmeyer, H.U. and Bernt, E. (1974) In: Methods of Enzymatic Analysis, (Bergmeyer, H.U., ed.), Vol.2, pp. 574-579. Weinheim: Verlag Chemie GmbH.

4. Cabanié, M. and Godfraind, T. (1988) The role of histamine in the cardiovascular system. Drugs Exptl Clin Res 14, 141-147.

5. De Groot, M.J.M., Coumans, W.A., Willemsen, P.H.M. and Van der Vusse, G.J. (1993) Substrateinduced changes in the lipid content of ischemic and reperfused myocardium: its relation to hemodynamic recovery. Circ Res 72, 176-186.

6. Dvorak, A.M. (1991) In: Blood Cell Biochemistry, (Harris, J.R., ed.), Vol. 4, pp. 3-25. New York/London: Plenum Press.

7. Engler, F.L., Dahlgren, M.D., Morris, D., Peterson, M.A. and Schmid-Schoenbein. (1986) Role of leukocytes in the response to acute myocardial ischemia and reflow in dogs. Am J Physiol 251, $\mathrm{H} 314-\mathrm{H} 323$.

8. Entman, M.L., Michael, L., Rossen, R.D., Dreyer, W.J., Anderson, D.C., Taylor, A.A. and Smith, C.W. (1991) Inflammation in the course of early myocardial ischaemia. Faseb J 5, 2529-2537.

9. Feuvray, D. and De Leiris, J. (1975) Ultrastructural modifications induced by reoxygenation in the anoxic isolated rat heart perfused without exogenous substrate. I Mol Cell Cardiol 7, 307. 314.

10. Galli, S.J. (1990) New insights into 'The riddle of the mast cells': microenvironmental regulation of mast cell development and phenotypic heterogenity. Lab Invest 62, 5-33.

11. Galli, S.J., Dvorak, A.M. and Dvorak, H.F. (1984) Basophils and mast cells: morphologic insights into their biology, secretory patterns and function. Prog Allergy 34, 1-141. 
12. Galli, S.J., Gordon, J.R. and Wershil, B.K. (1993) Mast cell cytokines in allergy and inflammation. Agents Actions Suppl 43, 209-220.

13. Gruber, B.L. and Schwartz, L.B. (1990) The mast cell as an effector of connective tissue degradation: A study of matrix susceptibility to human mast cells. Biochem Biophys Res Commun $171,1272-1278$.

14. Hearse, D.J. and Humphrey, S.M. (1975) Enzyme release during myocardial anoxia: a study of metabolic protection. J Mol Cell Cardiol 7, 463-482.

15. Hearse, D.J., Humphrey, S.M., Nayler, W.G., Slade, A. and Border, D. (1975) Ultrastructural damage associated with reoxygenation of the anoxic myocardium. J Mol Cell Cardiol 7, 315-324.

16. Henderson, W.R. and Kaliner, M. (1979) Mast cell granule peroxidase: location, secretion, and SRS-A inactivation. I Immunol 122, 1322-1328.

17. Ito, B.R., Engler, R.L. and Del Balzo, U. (1993) Role of cardiac mast cells in complement C5ainduced myocardial ischemia. Am J Physiol 264, $\mathrm{H} 1346-\mathrm{H} 1354$.

18. Keller, A.M., Clancy, R.M., Barr, M.L., Marboe, C.C. and Cannon, P.J. (1988) Acute reoxygenation injury in the isolated rat heart: role of resident cardiac mast cells. Circ Res 63, 1044-1052.

19. Langendorfi, O. (1895) Untersuchungen am ueberlebenden Saugethierherzen. Arch Ges Physiol $61,291-332$.

20. Linssen, M.C.J.G., Vork, M.M., De Jong, Y.F., Glatz, J.F.C. and Van der Vusse, G.J. (1990) Fatty acid oxidation capacity and fatty acid binding protein content of different cell types isolated from rat heart. Mol Cell Biochem 98, 19-25.

21. Lowry, O.H., Rosebrough, N.J., Farr, A.L. and Randall, R.J. (1951) Protein measurement with the folin phenol reagent. I Biol Chem 193, 265-275.

22. Lucchesi, B.M. (1990) Modulation of leukocyte-mediated myocardial reperfusion injury. Annu Rev Physiol 52, 561-568.

23. Mannaioni, P.F., Gianella, E., Palmerani, B., Gambassi, F., Bani-Sacchi, T., Bianchi, S. and Masini, E. (1988) Free radicals as endogenous histamine releasers. Agents Actions 23, 129-142.

24. Masini, E., Bianchi, S., Gambassi, F., Palmerani, B., Pistelli, A., Carlomagno, L. and Mannaioni, P.F. (1990) Ischemia/reperfusion injury and histamine release in isolated and perfused guinea-pig heart: pharmacological interventions. Agents Actions 30, 198-201.

25. Rakusan, K., Sarkar, K., Turek, Z. and Wicker, P. (1990) Mast cells in the rat heart during normal growth and in cardiac hypertrophy. Circ Res 66, 511-516.

26. Rickard, A. and Lagunofi, D. (1994) Eosinophil peroxidase accounts for most if not all of the peroxidase activity associated with isolated rat peritoneal mast cells. Int Arch Allergy Immunol 103, 365-369.

27. Rydzynski, K., Kolago, B., Zaslonka, J. and Kuroczynski, W. (1988) Distribution of mast cells in human heart auricles and correlation with tissue histamine. Agents Actions 23, 273-275. 


\section{| CHAPTER 8}

\section{Mast Cells and the Induction of Endothelial Leukocyte-Adhesion Molecules in Vitro}

Charles M.C.J. van Haaster, Josien G. Derhaag, Wim Engels, Paul J.M.R. Lemmens, Annemie P. Gijsen, Gerard Hornstra, Ger J. Van der Vusse and Adriaan M. Duijvestijn

Mast cells and the induction of endothelial leukocyte-adhesion molecules in vitro

(Submitted for Publication) 


\subsection{ABSTRACT}

We approached the possible role of cardiac mast cells in the expression of endothelial leukocyte-adhesion molecules ICAM-1, VCAM-1 and E-selectin in the intact heart with an in vitro rat experimental model. Isolated rat peritoneal mast cells and rat heart endothelial cell lines were used for ICAM-1 and VCAM-1 induction studies, whereas for E-selectin studies human umbilical vein endothelial cells (HUVEC) were used, since no suitable antibodies against rat E-selectin were available. Mast cells were incubated either in direct cell-cell contact with endothelial cell monolayers (contact studies) or separated from endothelial cells through a permeable membrane (transwell studies). To study the effects of mast cell degranulation on the induction of leukocyte-adhesion molecules, mast cells were activated with compound 48/80. Both in contact and transwell studies, mast cells induced the expression of VCAM-1 and E-selectin in endothelial cells, whereas the induction of ICAM-1 was marginal. The induction of VCAM-1 and E-selectin expression was not related to mast cell degranulation or to mast cell-derived products such as histamine, but seemed to be provoked by, so far, undefined substance(s) constitutively released by these cells. The direct contact between mast cells and endothelial cells potentiated the induction of VCAM-1 and E-selectin in endothelial cells. The results suggest that in the heart mast cells may play a distinct role in the concert of early inflammatory events leading to the expression of endothelial cell adhesion molecules involved in attracting blood leukocytes.

\subsection{INTRODUCTION}

Numerous reports have shown that ischemia/reperfusion triggers leukocytes to infiltrate the myocardium where they increase the extent of myocardial injury $8,20,26,27,29$, possibly by releasing cytotoxic compounds such as proteases and reactive oxygen species, which may directly injure cardiomyocytes. ${ }^{9}$

The extravasation of leukocytes during an inflammatory response is a multistepprocess, which requires the interaction of these cells with the vascular endothelium. This process consists of at least two distinct adhesive events. The first event involves rolling of leukocytes along the endothelial membrane, a process which is mediated by selectins (P-selectin, E-selectin and L-selectin) and their respective sialylated carbohydrate ligands. ${ }^{2}$ P-selectin and E-selectin are expressed by endothelial cells, whereas L-selectin is expressed by leukocytes. E-selectin mediates the interaction between endothelial cells and leukocytes, e.g., neutrophils, monocytes and memory CD4+ lymphocytes. 4,16,28 After rolling, firm adhesion is accomplished by endothelial adhesion molecules with immunoglobulin domains such as VCAM-1 and ICAM-1, which mediate adherence of leukocytes bearing $\beta 1$-integrins such as VLA-4 (CD 49d) and $\beta 2$-integrins such as LFA-1 (CD11a/CD18) and Mac-1 (CD11b/CD18), 7,21,22 VCAM-1 has been shown to mediate the adhesion of lymphocytes, monocytes, eosinophils and basophils to endothelial cells ${ }^{4,22}$, whereas ICAM-1 mediates adhesion of all leukocytes. 6,7 
The trigger of an inflammatory response, ultimately resulting in extravasation of leukocytes to a particular target tissue, requires a signal that is presumably released from the injured site. The mast cell, by virtue of its perivascular localization and its capacity to release a variety of potent inflammatory mediators such as histamine, platelet activating factor (PAF), TNF $\alpha$ and various interleukins such as IL-4 and IL- $8^{11}$, may serve such function. Indeed, products released from mast cells have been shown to increase the expression of E-selectin in human skin ${ }^{12,32}$ and to cause extravasation of leukocytes in mouse skin and the hamster cheeck pouch. ${ }^{25,33}$ Since ischemia/reperfusion is accompanied by mast cell degranulation and hence, by the release of mast cell products $^{18,19}$, longer-term effects of this process in vivo might involve the extravasation of leukocytes and, consequently, mast cells may contribute to the extent of ischemia/reperfusion-induced injury to cardiomyocytes. In the process of leukocyte extravasation, the induction of endothelial leukocyte-adhesion molecules is an important step.

We approached the potential role of cardiac mast cells in the induction of endothelial leukocyte-adhesion molecules such as ICAM-1, VCAM-1 and E-selectin in the intact heart with an in vitro rat experimental model. Since isolation of mast cells from cardiac tissue usually results in low yield and high impurity ${ }^{1,23}$, peritoneal mast cells were used instead. It should be noted that the latter cells, similar to cardiac mast cells, belong to the connective tissue-type. Mast cells were studied for their capacity to induce the expression of ICAM-1, VCAM-1 and E-selectin in cultured endothelial cells. For ICAM-1 and VCAM-1 expression studies, cultured endothelial cells from rat heart origin were used, whereas for E-selectin studies human umbilical vein endothelial cells (HUVEC) were used, since no suitable rat E-selectin antibodies were available. Since in vivo mast cells are located either in direct contact with or in the close vicinity of vascular endothelial cells, in experiments, mast cells were incubated either in direct contact with endothelial cells, or separated from these cells through a permeable membrane. Mast cells were activated with compound $48 / 80$ in order to study the possible role of mast cell degranulation in the induction of endothelial leukocyte-adhesion molecules.

The results show that in this experimental set-up products released from mast cells induced the expression of VCAM-1 and E-selectin in endothelial cells, whereas the induction of ICAM-1 by products released from mast cells was marginal. The induction of VCAM-1 and E-selectin expression was not related to mast cell degranulation and mast cell-derived products such as histamine, but seemed to be provoked by (an) so far undefined substance(s) constitutively released from mast cells. Direct contact between mast cells and endothelial cells potentiated the expression of VCAM-1 and E-selectin.

\subsection{MATERIALS AND METHODS}

\section{Endothelial Cells and Cell Culturing}

Experiments were performed with various rat heart endothelial cell (RHEC) lines produced from cultures of heart endothelial cells isolated by ex vivo perfusion with collagenase. ${ }^{5}$ These lines have been characterized for their endothelial nature and expression of cell adhesion molecules after stimulation with cytokines. ${ }^{5}$ For the studies 
described here, two RHEC lines were used: (1) RHEC-3, which expressed low levels of ICAM-1 under non-stimulatory conditions, expression levels that could strongly be enhanced by cytokine stimulation and (2) RHEC-11 V+ (RHEC-11), a recently prepared line from RHEC-11 which shows a high expression of VCAM-1 after combined cytokine stimulation. When the effects of mast cells on ICAM-1 expression were studied, RHEC-3 was used, whereas RHEC-11 was used to investigate the effects of mast cells on VCAM1 expression. Endothelial cell (EC) lines were cultured in a $\mathrm{CO}_{2}$ incubator at $37{ }^{\circ} \mathrm{C}$ in culture flasks (Costar, Cambridge, UK). EC culture medium consisted of $40 \%$ RPMI 1640 (Gibco BRL, Life Technologies B.V, Breda, the Netherlands), 40\% M199 (Gibco), 20\% heat-inactivated foetal calf serum (FCS, Integro, Belgium), bovine brain extract (14.93 $\mathrm{mg} / \mathrm{ml})^{17}, 10 \mathrm{mM} \mathrm{NaHCO}$, penicillin (50 I.E./ml), streptomycin (50 $\left.\mu \mathrm{g} / \mathrm{ml}\right)$, fungizone $(2 \mu \mathrm{g} / \mathrm{ml})$, Hepes $(10 \mathrm{mM})$, heparin $(20 \mathrm{l} . \mathrm{E} . / \mathrm{ml})$ and L-glutamin $(2 \mathrm{mM})$. Endothelial cells were passaged routinely in 1 to 3 dilution. EC-viability was always $>95 \%$ as assessed by Trypan-blue exclusion. HUVEC were isolated according to Vossen et al. ${ }^{31}$ and were used in passage 3 to 4 .

\section{Mast cell Isolation}

Mast cells were isolated from the peritoneal cavity according to a slightly modified version of that described in Chapter 2. Briefly, rats were anaesthetized with diethyl ether and $20 \mathrm{ml}$ of sterile lavage buffer $\left(150 \mathrm{mM} \mathrm{NaCl}, 8 \mathrm{mM} \mathrm{Na} 2 \mathrm{HPO}_{4} .2 \mathrm{H}_{2} \mathrm{O}, 1.6 \mathrm{mM}\right.$ $\mathrm{KH}_{2} \mathrm{PO}_{4}, 0.1 \%$ gelatin (w/v) and 10 I.E./ml heparin, $\mathrm{pH} 7.4$ ) was injected intraperitoneally using a sterile infusion syringe (Abbocath-T 14Gx51 mm, Abbott, Ireland). After gentle massaging, the lavage buffer was collected through the syringe and transferred into a sterile tube. The isolation procedures were identical to those described in Chapter 2, except that they were performed in a laminar-flow cabinet using sterile materials and solutions. At the end of the procedure, cells were resuspended in EC culture medium to a final concentration of $10^{6}$ cells $/ \mathrm{ml}$ and were counted using a Coulter Counter (Coulter Electronics, Krefeld, FRG).

\section{Mast cell/Endothelial Cell Incubations}

Endothelial cells (EC) were seeded into fibronectin-coated $(200 \mathrm{mg} / \mathrm{ml}$ fibronectin incubated for $30 \mathrm{~min}$ ) tissue-culture dishes ( 6 well-plates, Costar) and were subsequently incubated at $37{ }^{\circ} \mathrm{C}$ in an atmosphere of $95 \%$ air $/ 5 \% \mathrm{CO}_{2}$ in $2.5 \mathrm{ml} \mathrm{EC}$ culture medium. At confluency, the medium was replaced by $2.5 \mathrm{ml}$ fresh EC culture medium.

In contact studies (contact incubations), mast cells were added to the culture dishes to a final concentration of $2 \cdot 10^{5} \mathrm{cells} / \mathrm{ml}$. In experiments in which mast cells were separated from endothelial cells (transwell incubations), inserts (membrane thickness $10 \mu \mathrm{m}$, pore size $0.4 \mu \mathrm{m}$, Costar) were used to which mast cells were added. The incubation volume in both conditions was $2.5 \mathrm{ml}$. Inserts were presoaked in EC culture medium. When indicated, mast cell degranulation was induced by addition of compound $48 / 80(10 \mu \mathrm{g} / \mathrm{ml})$. Endothelial cells were also incubated in the presence of cytokines (a combination of $400 \mathrm{U} / \mathrm{ml} \mathrm{TNF} \alpha$ and $200 \mathrm{U} / \mathrm{ml}$ IFN $\gamma$ ) or lipopolysaccharide (LPS, $10 \mu \mathrm{g} / \mathrm{ml}$ ). In addition, endothelial cells were incubated with two concentrations of histamine $(3.5 \mu \mathrm{M}$ or $35 \mu \mathrm{M})$. The effects of mast cells on ICAM-1 and VCAM-1 
expression were studied after 16 hours incubation, which was shown in preliminary experiments to be a time point falling within the peak expression of ICAM-1 and VCAM-1 in RHEC (data not shown). When the effects of mast cells on the expression of E-selectin were studied, incubations were carried out for 4 hours, a time point falling within the peak expression induced with cytokines. At the end of the experiment, the medium was collected and transferred into Eppendorf cups. After centrifugation at $15,000 \times g$ for $30 \mathrm{~s}$, supernatants were stored at $-70{ }^{\circ} \mathrm{C}$ until analysis for the histamine content.

\section{Cardiomyocytes and Heart Fibroblasts}

Cardiomyocytes (CMC) were isolated from adult rat hearts according to Linssen et al. ${ }^{15}$ The cells were studied for their capacity to increase ICAM-1 and VCAM-1 expression in RHEC-3 and RHEC-11, respectively. CMC were added to confluent monolayers of endothelial cells in contact incubations (final concentrations $5.10^{4}$ and $5.10^{3}$ cells/incubation, $n=2$ ). Fibroblasts were derived from a cell-line (CFLC) prepared from fibroblast-cultures of rat heart origin. ${ }^{15}$ CFLC were also tested for their capacity to increase ICAM-1 and VCAM-1 expression in transwell incubations (final concentration $5 \cdot 10^{5}$ cells/incubation, $n=2$ ).

\section{Determination of Histamine Content}

The extent of mast cell degranulation was quantitated by determination of the percentual histamine release in mast cell/EC incubations. Histamine was determined by High Performance Liquid Chromatography as described in Chapter 2. Total releasable mast cell histamine was determined after lysing the cells with $0.1 \%(\mathrm{w} / \mathrm{v})$ Triton X-100 (see Chapter 5). This amount of histamine (about $35 \mu \mathrm{M}$ ) was added to EC monolayers and was used as a reference for the calculation of the percentual histamine release in mast cell/EC incubations.

\section{Cytocentrifuge Preparations}

Endothelial cell monolayers were washed with phosphate-buffered saline (PBS) and subsequently treated with $100 \mu \mathrm{l}$ of a trypsin $(0.25 \%) /$ EDTA $(0.2 \%)$ solution. After 1 min, trypsin was inactivated by addition of $5 \mathrm{ml}$ of a solution consisting of M199 (90\%, $\mathrm{v} / \mathrm{v})$, foetal calf serum $(10 \%)$, penicillin $(100 \mathrm{I} . \mathrm{E} . / \mathrm{ml})$, streptomycin $(100 \mu \mathrm{g} / \mathrm{ml})$, Lglutamin $(2 \mathrm{mM})$ and Hepes $(25 \mathrm{mM})$. After centrifugation at $200 \times \mathrm{g}$ for $10 \mathrm{~min}$, endothelial cell suspensions were routinely fixed with $1 \%(\mathrm{w} / \mathrm{v})$ paraformaldehyde in PBS for $30 \mathrm{~min}$ at $4{ }^{\circ} \mathrm{C}$. After three consecutive washing-steps with PBS, the cells were resuspended in $2.5 \mathrm{ml}$ of EC culture medium. Preparations were made in a Cytocentrifuge (Cytospin 3, Shandon, UK) used at $680 \mathrm{rpm}$ for $10 \mathrm{~min}$. Preparations were stored in an exsiccator.

\section{Immunoperoxidase Staining}

Staining was performed on paraformaldehyde-fixed cytocentrifuge preparations, using a two-step immunoperoxidase technique. In preliminary experiments, saturating concentrations of the antibodies diluted in PBSA (PBS containing $0.05 \%$ bovine serum 
albumin, BSA) were determined (data not shown). Preparations of RHEC were incubated with 1A29, a mouse monoclonal antibody (mAb) against rat ICAM-1 (donated by Dr. Miyasaka, Osaka University, Japan), 5F10, a mouse mAb against rat VCAM-1 (donated by Drs. R. Lobb and P. Chisholm, Biogene, Cambridge, USA) or irrelevant isotype-matched control antibodies. HUVEC cytocentrifuge preparations were incubated with BBIG-E4 (R\&D Systems, Abingdon, UK), a mouse mAb against human E-selectin. Preliminary experiments with CL-3 (a mouse monoclonal antibody against human E-selectin, a kind gift from Dr. D.C. Anderson, Upjohn Co., Kalamazoo, USA) gave results which were comparable to those observed with BBIG-E4 (data not shown). 6.5B5, a monoclonal mouse anti-human VCAM-1 antibody was donated by Dr. D. Haskard (University of London, UK). Incubation with first-step antibodies was carried out for $60 \mathrm{~min}$ in a humidified chamber. Thereafter, preparations were washed with PBS and incubated for $30 \mathrm{~min}$ with peroxidase-conjugated second-step antibodies (rabbit $\mathrm{F}(\mathrm{ab})_{2}$ anti-mouse IgG, Dako, Copenhagen, Denmark) in PBSA. When RHEC were stained, normal rat serum $(3 \%, \mathrm{v} / \mathrm{v})$ was added to prevent non-specific binding of the rabbit anti-mouse IgGs, whereas normal human serum was added when HUVEC were stained. After washing with PBS, preparations were incubated for 10 min with diaminobenzidine (DAB) in PBS $(0.05 \%, w / v)$ in the presence of $0.5 \% \mathrm{H}_{2} \mathrm{O}_{2}(\mathrm{v} / \mathrm{v})$. The reaction was stopped by placing the preparations in water. After counterstaining with hematoxylin, preparations were routinely dehydrated and coverslipped with Entellan ${ }^{\oplus}$ (Merck, Darmstadt, FRG). Quantification of positive cells occurred microscopically by counting a minimum of 200 cells over at least two fields, or in case of low numbers of positive cells (i.e., ICAM-1 expression), a minimum number of 10 positive cells.

\section{Histochemistry on Cardiac Tissue Sections}

In order to remove blood cells from the tissue, hearts were shortly (30 s) perfused according to Langendorff. Hearts were fixed by perfusion with $15 \mathrm{ml}$ of formalin $(50 \%$ in PBS, v/v). After overnight incubation in formalin, parts of the tissue were processed for paraffin embedding using a Histokinette.

Endothelial cells were visualized by incubation of the sections with biotinylated Griffonia Simplificolia (BS-I, Sigma, St. Louis, USA), a lectin which specifically recognizes terminal $\alpha$-galactosyl residues on endothelial cells. Deparaffinized sections ( $4 \mu \mathrm{m})$ were incubated overnight with BS-I in the presence of BSA $(1 \%, w / v)$ and Tween-80 $(0.1 \%$, $v / v)$. After washing with PBS, sections were incubated with peroxidase-labeled avidin for $30 \mathrm{~min}$. After washing with PBS, sections were incubated with DAB $(0.05 \%, \mathrm{w} / \mathrm{v})$ in the presence of $0.15 \% \mathrm{H}_{2} \mathrm{O}_{2}$ until staining was considered optimal. The reaction was stopped by placing the sections in water. Thereafter, sections were incubated with $0.05 \%(w / v)$ toluidine blue for $5 \mathrm{~min}$ to visualize mast cells. Sections were rapidly dehydrated and coverslipped with Entellan

\section{Statistical Analysis}

Results are expressed as the percentage of positive cells after correction for expression levels in control endothelial cell incubations, i.e., in the absence of mast cells (mean 
values \pm SEM). Statistical analysis was performed using the non-parametric MannWhitney U-test. $\mathrm{P}$ values $\leq 0.05$ were considered to be statistically significant.

\subsection{RESULTS}

\section{Localization of Cardiac Mast cells}

Sections of formalin-fixed cardiac tissue were stained with BS-I and toluidine blue to visualize endothelial cells and mast cells, respectively. It was found that mast cells were located around large- and medium-sized blood vessels in the cardiac connective tissue strands. In addition, mast cells were also found to a lower extent around capillaries and postcapillary venules in the myocardium. More specifically, mast cells were located in the close vicinity of and sometimes in contact with endothelial cells (Fig. 8.1A).
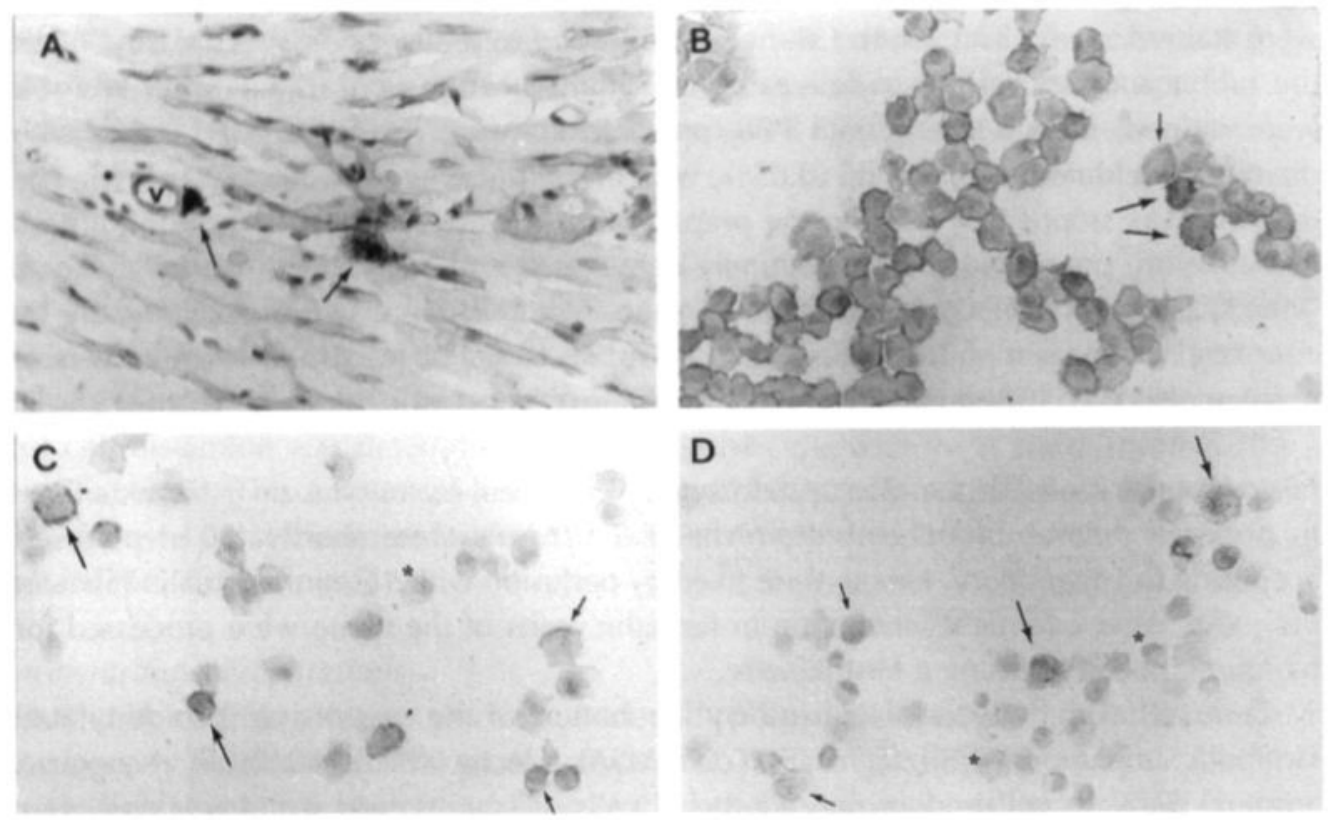

Figure 8.1 (A): Paraffin-sections of rat heart stained with BS-I lectin for visualization of endothelial cells and toluidine blue for mast cells. Arrows indicate mast cells in contact with or in the close vicinity of a blood vessel (v) (B,C,D): Cytocentrifuge preparations of EC cultures: immunoperoxidase staining with hematoxylin counterstaining. Large arrows indicate strongly positive cells, small arrows moderately positive cells. Asterisks indicate negative cells. (B): VCAM-1 induction in RHEC-11 by cytokines, showing positivity in the majority of the cells (C): VCAM-1 induction in RHEC-11 by mast cells (contact incubation), showing a distinct percentage of positive cells (D): E-selectin induction in HUVEC by mast cells (contact incubation), also showing a distinct percentage of positive cells.

\section{Mast Cells and ICAM-1 Expression}

Confluent monolayers of RHEC-3 were used to study the role of mast cells on the induction of ICAM-1. RHEC-3 showed low basal levels of ICAM-1 expression (about 5\% of positive cells) in the absence of mast cells (data not shown). In the transwell system, the presence of mast cells resulted in marginally increased expression levels of ICAM-1 in endothelial cells (Table 8.1). Direct contact between mast cells and endothelial cells 
promoted the expression of ICAM-1 in RHEC-3 (Table 8.1), but induction levels remained marginal $(6 \pm 1 \%)$. Both in transwell and direct contact incubations, expression levels of ICAM-1 were not increased in the presence of the mast celldegranulating agent compound $48 / 80$. In the absence of mast cells, no effects of compound $48 / 80$ as such on ICAM-1 expression were observed.

Table 8.1: Expression of ICAM-1, VCAM-1 and E-selectin in Cultured Endothelial Cells

\begin{tabular}{|c|c|c|c|c|c|c|c|c|}
\hline \multirow[t]{2}{*}{ Incubation ${ }^{1}$} & \multirow[t]{2}{*}{$\mathrm{MC}^{2}$} & \multirow[t]{2}{*}{ Activation $^{3}$} & \multicolumn{6}{|c|}{ Expression ( $\%$ of positive cells) ${ }^{5}$} \\
\hline & & & ICAM-1 & $n^{4}$ & VCAM-1 & $n$ & E-selectin & $\mathrm{n}$ \\
\hline Transwell & + & - & $2 \pm 1$ & 5 & $17 \pm 2$ & 7 & $6 \pm 2$ & 4 \\
\hline Transwell & + & + & $2 \pm 1$ & 5 & $19 \pm 4$ & 7 & $6 \pm 2$ & 4 \\
\hline Contact & + & - & $6 \pm 1^{\circ}$ & 5 & $34 \pm 6^{\circ}$ & 7 & $24 \pm 1^{\circ}$ & 4 \\
\hline Contact & + & + & $5 \pm 1^{\circ}$ & 5 & $31 \pm 5^{\circ}$ & 7 & $26 \pm 5^{\circ}$ & 4 \\
\hline Histamine ${ }^{6}$ & - & - & 0 & 3 & 0 & 3 & 0 & 2 \\
\hline Cytokines ${ }^{7}$ & - & - & $69(67-71)$ & 2 & $81(63-98)$ & 2 & 54 & 1 \\
\hline LPS $^{8}$ & . & . & 20 & 1 & 29 & 1 & 71 (63-79) & 2 \\
\hline
\end{tabular}

1 Mast cells were incubated either in direct cell-cell contact (Contact) with endothelial cells, or were separated from these cells by a permeable membrane (Transwell)

$2 \mathrm{MC}(+)$ indicates the presence of $2.5 \cdot 10^{5}$ mast cells per incubation (total incubation volume: $2.5 \mathrm{ml}$ )

3 Indicates the presence of the mast cell-degranulating agent compound $48 / 80(10 \mu \mathrm{g} / \mathrm{ml})$

4 Indicates the number of experiments

5 Results (mean values \pm SEM) are expressed as the percentage of positive cells after correction for basal expression levels in control endothelial cell incubations (<5\% in all experiments)

6 Histamine indicates incubation of endothelial cells in the presence of histamine ( $35 \mu \mathrm{M})$

7 Cytokines indicates incubation of endothelial cells in the presence of cytokines (a combination of

$T N F \alpha(400 \mathrm{U} / \mathrm{ml})$ and IFN $\gamma(200 \mathrm{U} / \mathrm{ml})$. The range is indicated between brackets

8 LPS indicates incubation of endothelial cells in the presence of lipopolysaccharide $(10 \mu \mathrm{g} / \mathrm{ml})$

Asterisks indicate statistically significant differences between expression levels in contact and corresponding transwell incubations

Microscopical examination of the mast cell/EC cultures showed that mast cell degranulation had occurred in compound 48/80-containing incubations. In addition, toluidine blue staining of cytocentrifuge preparations of mast cell/EC incubations with compound $48 / 80$ showed a distinct mast cell degranulation, characterized by the presence of released granules (not shown). In cytocentrifuge preparations from mast cell/EC incubations without compound 48/80, mast cell degranulation was almost absent. Mast cell degranulation was also demonstrated by measuring histamine contents in supernatants from mast cell/EC incubations with or without compound $48 / 80$. The histamine content of supernatants from mast cell/EC incubations with compound $48 / 80$ amounted to $80 \pm 5 \%$ of the total mast cell histamine content, whereas in the absence of this compound, histamine release was only $4 \pm 2 \%$.

The expression of ICAM- 1 in RHEC- 3 in the presence of mast cells was compared to that achieved upon combined cytokine stimulation. The observation that stimulation with a combination of $\mathrm{TNF} \alpha$ and IFN $\gamma$ resulted in a high percentage of positive cells $(71 \%$, mean of two experiments, range $67-75 \%)$ indicated that the relatively mild effect 
of mast cells with respect to ICAM-1 expression was not due to the fact that RHEC-3 could not adequately be provoked to express this leukocyte-adhesion molecule. This was supported by the finding that also LPS increased expression levels of ICAM-1 (Table 8.1).

\section{Mast Cells and VCAM-1 Expression}

The role of mast cells in the expression of VCAM-1 in rat heart endothelial cells was studied in RHEC-11. This cell line showed no basal expression of VCAM-1 (data not shown). The expression of VCAM-1 by RHEC-11 was significantly enhanced upon combined cytokine-stimulation with TNF $\alpha / \mathrm{IFN} \gamma$ ( $81 \%$ of positive cells, mean of two experiments, range $63-98 \%$, Table 8.1 ). A representative photograph of VCAM-1 expression induced by cytokines is shown in Fig. 8.1B. In the transwell system, incubation of mast cells with endothelial cells induced the expression of VCAM-1, both in the presence or absence of compound $48 / 80$ (Table 8.1). The direct contact of mast cells with endothelial cells increased the expression of VCAM-1 from $17 \pm 2 \%$ to $34 \pm$ $6 \%$. Expression levels in these conditions were comparable to those observed upon stimulation with LPS ( $29 \%$, one experiment). No additional effects of compound $48 / 80$ on expression levels of VCAM-1 were observed $(31 \pm 5 \%)$. A representative photograph of mast cell-induced VCAM-1 expression in RHEC-11 is shown in Fig. 8.1C. No effects of compound $48 / 80$ as such on VCAM-1 expression were observed. In preliminary experiments, in which the effects of mast cells on the expression of VCAM-1 in HUVEC were studied, effects were comparable to those observed in RHEC-11 (data not shown).

\section{Mast cells and E-selectin Expression}

Under normal cell-culturing conditions, HUVEC showed a low basal expression (2-3\% of positive cells) of E-selectin (data not shown). In the transwell system $(n=4)$, incubation of mast cells with HUVEC resulted in a small, but significantly increased expression of Eselectin in the latter cells $(6 \pm 2 \%$, Table 8.1$)$. Again, no additional effects of compound $48 / 80$ on the expression of E-selectin were observed, whereas large amounts of degranulated mast cells in toluidine blue stained cytocentrifuge preparations were observed. Similar to expression of ICAM-1 and VCAM-1 in cultured rat heart endothelial cells, the direct contact between mast cells and HUVEC strongly promoted the expression of E-selectin in these cells ( $24 \pm 1 \%$, Table 8.1). Again, no additional effects of compound $48 / 80$ on the expression of E-selectin were observed ( $26 \pm 5 \%)$. In the absence of mast cells, compound $48 / 80$ did not increase basal expression levels of E-selectin (data not shown). HUVEC were responsive to stimulation with cytokines or LPS, reaching expression levels of $54 \%$ (one experiment) and $75 \%$ (mean of two experiments, range $68-79 \%$ ), respectively. A representative photograph of mast cellinduced $\mathrm{E}$-selectin expression in HUVEC is shown in Fig. 8.1D.

\section{Histamine Stimulation of Endothelial Cells}

Although compound 48/80-induced histamine release was not accompanied by an increased expression of endothelial leukocyte-adhesion molecules, this does not rule out the possibility that a low basal release of histamine, observed in all mast cell/EC 
incubations, could be responsible for the induction of the investigated endothelial leukocyte-adhesion molecules. Therefore, histamine was added to the endothelial cell incubations in an amount equivalent to the total mast cell histamine content of 2.5.105 cells $(35 \mu \mathrm{M})$, or an amount which was ten-fold lower $(3.5 \mu \mathrm{M})$. For both concentrations of histamine tested no effects on expression levels of ICAM-1, VCAM-1 or E-selectin were observed (data not shown).

\section{Cardiomyocytes (CMC) and Fibroblasts (CFLC): Stimulation of Endothelial Cells}

In order to check if mast cell-induced expression of ICAM-1 and VCAM-1 in rat heart endothelial cells was mast cell-specific, CMC and CFLC were also studied for their capacity to induce expression ICAM-1 and VCAM-1 in RHEC cultures. Neither CMC (at concentrations of $5 \cdot 10^{3}$ and $5 \cdot 10^{4}$ cells/incubation) nor CFLC (at a concentration of $5 \cdot 10^{5}$ cells/incubation) induced ICAM-1 or VCAM-1 in endothelial cells.

\subsection{DISCUSSION}

We approached the possible role of cardiac mast cells in the induction of endothelial leukocyte-adhesion molecules in the intact heart in a rat experimental model in vitro. Peritoneal mast cells were studied for their capacity to increase the expression of ICAM1, VCAM-1 and E-selectin in cultured endothelial cells. For the effects of mast cells on ICAM-1 and VCAM-1 expression, rat heart endothelial cell (RHEC) lines were used, whereas for E-selectin studies human umbilical vein endothelial cells (HUVEC) were used. In addition, the localization of mast cells in cardiac tissue in situ was studied.

In agreement with earlier results of Rakusan et al. ${ }^{24}$, we observed that in the heart in situ, mast cells were located around large- and medium-sized blood vessels and around small myocardial vessels, either in the close vicinity of or in contact with endothelial cells. Therefore, in our in vitro system, mast cells were allowed to have either direct contact with endothelial cells (contact incubations) or were separated from these cells by a permeable membrane (transwell incubations).

When compared to expression of ICAM-1 upon stimulation with TNF $\alpha /$ IFN $\gamma$, reaching a percentage of positive cells of about $70 \%$, mast cells only marginally induced the expression of ICAM-1 in RHEC-3, both in transwell $(2 \pm 1 \%)$ and in contact incubations $(6 \pm 1 \%)$. In contrast, mast cells were found to have profound effects on the expression of VCAM-1 and E-selectin, especially in contact incubations, reaching values of about 40 to $50 \%$ of those observed upon cytokine-stimulation. In preliminary studies we observed that the effects of mast cells on VCAM-1 expression in HUVEC were comparable to those observed in RHEC-11. Therefore, it is tempting to assume that the effects of mast cells on the expression of E-selectin in heart endothelial cells would have been similar to those observed in HUVEC. In transwell incubations, mast cells induced the expression of VCAM-1 and E-selectin, but to much lower levels as those found in contact incubations. This suggests that in vivo, mast cells may actually stimulate endothelial cells to express leukocyte-adhesion molecules such as VCAM-1 and Eselectin. Since the expression of these adhesion molecules was significantly increased in incubations in which mast cells were in direct contact with endothelial cells, cardiac 
mast cells in contact with vascular endothelial cells in vivo may be considered most effective in local induction of VCAM-1 and E-selectin. This might be due to the fact that in these conditions, high local concentrations of mast cell-derived mediator(s) are achieved. Moreover, another relevant mechanism may be that 'cross-talk' between mast cells and endothelial cells through direct cell-surface interactions contributes to activation of endothelial cells.

We found that incubation of endothelial cells with mast cells in the presence of compound 48/80 did not have any additional effects on the expression of ICAM-1, VCAM-1 and E-selectin in endothelial cells. The absence of effects of compound 48/80 on adhesion molecule expression was not due to a high extent of non-specific mast cell degranulation, since the histamine content in EC supernatants in non-stimulatory conditions was only $4 \pm 2 \%$ of the total mast cell histamine content. In addition, microscopic examination of toluidine blue stained-cytocentrifuge preparations of these incubations revealed a highly homogenous population of mast cells, showing almost no signs of mast cell degranulation. Therefore, the results indicate that (a) mediator(s) responsible for the induction of VCAM-1, E-selectin, and to a lesser extent, ICAM-1, in endothelial cells, is not contained in secretory granules of mast cells, but rather seems to be constitutively released by these cells. For the moment, it cannot be concluded which mediator(s) released from mast cells is (are) responsible for the observed effects. Interestingly, both TNF $\alpha$ and IL-1, which may potentially be released from mast cells ${ }^{11}$, have been shown to increase the expression of VCAM-1 and E-selectin in endothelial cells in vitro. ${ }^{3,22}$ At least for histamine, which is stored in large amounts in secretory granules of mast cells, we could not find any effect of this compound on the induction of ICAM-1, VCAM-1 and E-selectin, both at low and high concentrations. This indicates that histamine can be excluded from the list of putative mast cell-derived products relevant to expression of ICAM-1, VCAM-1 and E-selectin. The observation that cardiomyocytes and fibroblast-like cells did not increase expression levels of ICAM-1 and VCAM-1 suggests that the observed effects are specific for mast cells.

Although the approach used in this in vitro study differs at some points from the situation in vivo (e.g., absence of blood cells, presence of mast cells at the luminal side of endothelial cells, absence of interstitial matrix structures between mast cells and endothelial cells), the results suggest that in vivo, mast cells may be involved in regulation of leukocyte-adhesion during the early inflammatory response. Since continuous expression of E-selectin and VCAM-1 is not observed in vivo under normal physiological conditions, this suggest that cardiac mast cells and the, so far, undefined mediator(s) constitutively released from these cells in vitro, are apparently little effective in the direct induction of the investigated leukocyte-adhesion molecules in vivo. Possibly, (the) mast cell-derived mediator(s) is (are) rapidly degraded or effused, preventing high local concentrations. Alternatively, (the) mediator(s) generated by mast cells may serve to increase the sensitivity of endothelial cells to triggers locally generated by other cells or by the endothelium itself. Another possibility is that in vivo products released from other cells residing in the vicinity of mast cells, such as cardiomyocytes, inhibit the formation, release or the effect of the mast cell-derived mediator(s). It is tempting to speculate that after ischemia/reperfusion, in which cardiomyocytes are 
severely injured, the capacity of these cells to inhibit the release/formation and/or the effect of mast cell-derived mediators on endothelial cells is reduced or lost. In this context, by increasing the infiltration of leukocytes into the affected region, mast cells might contribute to ischemia/reperfusion-induced injury to cardiomyocytes in vivo.

Recent observations have shown that in the rat mesenterium, compound 48/80induced mast cell degranulation induced P-selectin-dependent leukocyte rolling and CD-18-dependent leukocyte adhesion. These processes were significantly reduced in the presence of the histamine $\mathrm{H1}$-receptor antagonist diphenhydramine and the PAFantagonist WEB 2086, respectively. ${ }^{10}$ In addition, in a similar model, histamine has been shown to induce P-selectin-dependent leukocyte rolling. ${ }^{13,14}$ These results suggest that products released from mast cells, such as histamine, contribute to leukocyte rolling in vivo. However, findings from others have indicated that in the rat mesenterium, P-selectin-dependent leukocyte rolling and adhesion in mast celldependent inflammation is evoked by mediators other than histamine. ${ }^{30}$ Therefore, whereas for E-selectin expression we could not find evidence for a role of histamine, for P-selectin-mediated leukocyte rolling the role of histamine is equivocal and, therefore, remains to be established.

In conclusion, data from the present study show that mast cells are capable to induce the expression of VCAM-1, E-selectin and to a lesser extent, ICAM-1 in cultured endothelial cells. The induction of these endothelial leukocyte-adhesion molecules is not related to mast cell degranulation, but seems to be effected by (a) mediator(s) constitutively released from these cells. Direct contact between mast cells and endothelial cells substantially amplifies the expression of these leukocyte-adhesion molecules. Our data indicate that mast cell-derived products other than histamine may play an important role in vivo in the concert of early inflammatory events, ultimately leading to the expression of endothelial cell adhesion molecules relevant for infiltration of blood leukocytes.

\subsection{REFERENCES}

1. Assem, E.S.K., Machado, F.R.D. and Ghanem, N.S. (1986) Cardiac mast cells: partial purification of guinea-pig atrial mast cells and release of histamine and leukotriene $C_{4}$ by immune and nonimmune stimuli. Agents Actions 18, 167-171.

2. Bevilacqua, M.P. (1993) Leukocyte adhesion molecules. Annu Rev Immunol 11, 767-784.

3. Bevilacqua, M.P., Stengelin, S., Gimbrone Jr., M.A. and Seed, B. (1989) Endothelial leukocyteadhesion molecule-1: an inducible receptor for neutrophils related to complement regulatory proteins and lectins. Science 243, 1160-1165.

4. Carlos, T., Kovach, N., Schwartz, B., Rosa, M., Newman, B. and Wayner, E. (1991) Human monocytes bind to two cytokine-induced adhesive ligands on cultured human endothelial cells: endothelial-leukocyte adhesion molecule-1 and vascular cell adhesion molecule-1. Blood 77, 2266-2271.

5. Derhaag, J.G., Duijvestijn, A.M., Emeis, J.J., Engels, W. and Van Breda-Vriesman, P.J.C. (1996) Production and characterization of spontaneous rat heart endothelial cel lines. Lab Invest (in press).

6. Dustin, M.L., Rothlein, R., Bhan, A.K., Dinarello, C.A. and Springer, T.A. (1986) Induction by IL1 and interferon-gamma: tissue distribution, biochemistry and function of a natural adherence molecule (ICAM-1). I Immunol 137, 245-254. 
7. Dustin, M.L. and Springer, T.A. (1991) Lymphocyte function-associated antigen-1 (LFA-1) interaction with intercellular molecule-1 (ICAM-1) is one of at least three mechanisms for lymphocyte adhesion to cultured endothelial cells. J Cell Biol 107, 321-331.

8. Engler, R.L., Dahlgren, M.D., Morris, D.D., Peterson, M.A. and Schmid-Schonbein, G.W. (1986) Role of leukocytes in response to acute myocardial ischemia and reflow in dogs. Am J Physiol 251, $\mathrm{H} 314-\mathrm{H} 323$.

9. Entman, M.L., Michael, L., Rossen, R.D., Dreyer, W.J., Anderson, D.C., Taylor, A.A. and Smith, C.W. (1991) Inflammation in the course of early myocardial ischemia. Faseb J 5, 2529-2537.

10. Gaboury, J.P., Johnston, B., Niu, X.F. and Kubes, P. (1995) Mechanisms underlying acute mast cell-induced leukocyte rolling and adhesion in vivo. J Immunol 154, 804-813.

11. Galli, S.J., Gordon, J.R. and Wershil, B.K. (1993) Mast cell cytokines in allergy and inflammation. Agents Actions Suppl 43, 209-220.

12. Klein, L.M., Matis, W.L. and Murphy, G.F. (1989) Degranulation of human mast cells induces an endothelial antigen central to leukocyte adhesion. Proc Natl Acad Sci USA 86, 8972-8976.

13. Kubes, P. and Kanwar, S. (1994) Histamine induces leukocyte rolling in post-capillary venules. $A$ P-selectin-mediated event. I Immunol 152, 3570-3577.

14. Ley, K. (1994) Histamine can induce leukocyte rolling in rat mesenteric venules. Am J Physiol $267,1017-1023$.

15. Linssen, M.C.J.G., Vork, M.M., De Jong, Y.F. and Van der Vusse, G.J. (1990) Fatty acid oxidation capacity and fatty acid-binding protein content of different cell types isolated from rat heart. Mol Cell Biochem 98, 19-25.

16. Luscinskas, F.W., Cybulsky, M.I., Kiely, J.M., Peckins, C.S., Davis, V.M. and Gimbrone Jr., M.A. (1991) Cytokine-activated human endothelial monolayers support enhanced neutrophil transmigration via a mechanism involving both endothelial-leukocyte adhesion molecule-1 and intercellular adhesion molecule-1. J Immunol 146, 1617-1625.

17. Maciag, T., Cerundole, I., Istey, S., Kelly, P.R. and Foriand, R. (1979) An endothelial cell growth factor from bovine hypothalamus: identification and partial characterization. Proc Natl Acad Sci USA 76, 5674-5678.

18. Masini, E., Bianchi, S., Gambassi, F., Palmerani, B., Pistelli, A., Carlomagno, L. and Mannaioni, P.F. (1990) Ischemia/reperfusion injury and histamine release in isolated and perfused guinea-pig heart: Pharmacological interventions. Agents Actions 30, 198-201.

19. Masini, E., Giannella, E., Bianchi. S, Palmerani, B., Pistelli, A. and Mannaioni, P. (1988) Histamine release in acute coronary occlusion-reperfusion in isolated guinea-pig heart. Agents Actions 23 , 266-269.

20. Mullane, K.M., Read, N., Salmon, J.A. and Moncada, S. (1984) Role of leukocytes in acute myocardial infarction in anesthetized dogs. Relationship to myocardial salvage by antiinflammatory drugs. J Pharmacol Exp Ther 228, 510-522.

21. Oda, T., Katori, M., Hatanaka, K. and Yamashina, S. (1992) Five steps in leukocyte extravasation in the microcirculation by chemoattractants. Mediat Inflamm 1, 403-409.

22. Osborn, L., Hession, C., Tizard, R., Vassallo, C. and Luhowskyj, S. (1989) Direct expression cloning of vascular cell adhesion molecule-1, a cytokine-induced endothelial protein that binds to lymphocytes. Cell 59, 1203-1211.

23. Patella, V., Marino, I., Lampärter, B., Arbustini, E., Adt, M. and Marone, G. (1995) Human heart mast cells: isolation, purification, ultrastructure and immunologic characterization. J Immunol 154, 2855-2865.

24. Rakusan, K., Sarkar, K., Turek, Z. and Wicker, P. (1990) Mast cells in the rat heart during normal growth and in cardiac hypertrophy. Circ Res 66, 511-516.

25. Raud, J., Lindbom, L., Dahlen, S.E. and Hedqvist, P. (1989) Periarteriolar localization of mast cells promotes oriented interstitial migration of leukocytes in the hamster cheeck pouch. Am J Pathol 134, 161-166.

26. Romson, J.L., Hook, B.G., Kunkel, S.L., Abrams, G.D., Schork, M.A. and Lucchesi, B.R. (1983) Reduction of the extent of ischemic myocardial injury by neutrophil depletion in the dog. Circulation 67, 1016-1023.

27. Romson, J.L., Hook, B.G., Rigot, V., Schork, M.A., Schwanson, D.P. and Lucchesi, B.R. (1982) The effect of ibuprofen on accumulation of Indium-labeled platelets and leukocytes in experimental myocardial infarction. Circulation 66, 1002-1011.

28. Shimuzu, Y., Shaw, S., Graber, N., Gopal, T.V., Horgan, K.J. and Van Seventer, G.A. (1991) Activation-independent binding of human memory $T$ cells to adhesion molecule ELAM-1. Nature 349, 799-802. 
29. Simpson, P.J., Mickelson, J., Fantone, J.C., Gallagher, K.P. and Lucchesi, B.R. (1987) Iloprost inhibits neutrophil function in vitro and in vivo and limits experimental infarct size in canine heart. Circ Res 60, 666-673.

30. Thorlacius, H., Raud, J., Rozengren-Beezley, S., Forrest, M.J., Hedqvist, P. and Lindbom, L. (1994) Mast cell activation induces P-selectin-dependent leukocyte rolling and adhesion in postcapillary venules in vivo. Biochem Biophys Res Commun 203, 1043-1049.

31. Vossen, R.C.R.M., Van Dam-Mieras, M.C.E., Lemmens, P.J.M.R., Hornstra, G. and Zwaal, R.F.A. (1991) Membrane fatty acid composition and endothelial cell functional properties. Biochim Biophys Acta 1083, 243-251.

32. Walsh, L.J., Trinchieri, G., Waldorf, H.A., Whitaker, D. and Murphy, G.F. (1991) Human dermal mast cells contain and release tumor necrosis factor $\alpha$, which induces endothelial leukocyte adhesion molecule-1. Proc Natl Acad Sci USA 88, 4220-4224.

33. Wershil, B.K., Wang, Z.S., Gordon, J.R. and Galli, S.J. (1991) Recruitment of neutrophils during IgE-dependent cutaneous late phase reactions in the mouse is mast cell-dependent. I Clin Invest $87,446-451$. 
$\left.\right|_{\text {CHAPTER }} 9$

General Discussion 


\section{General Remarks}

Studies in various cell types, such as endothelial cells and platelets, have indicated that the formation of eicosanoids is strongly influenced by diet-induced modifications in the fatty acid composition of cellular membranes. We were interested to know to which extent in mast cells, the formation of prostanoids and hydroxy fatty acids and the degranulation process were controlled by the membrane fatty acid composition. To study this, a technique to isolate peritoneal mast cells in high purity and a method to quantitate the amount of histamine (a well-known marker of mast cell degranulation) in biological samples were developed. In peritoneal mast cells, it has been shown that a high release of histamine release is not necessarily accompanied by a high release of $P G D_{2}$. The responsible mechanisms for this, so-called, differential release of histamine and $\mathrm{PGD}_{2}$ are largely unknown. We studied to which extent in mast cells, increases in the cytosolic $\mathrm{Ca}^{2+}$ concentration and protein tyrosine kinases were responsible for the differential release of histamine and $P \mathrm{PD}_{2}$. Since studies in tissues such as rat mesenterium and hamster cheeck pouch have indicated that products released from mast cells are involved in the expression of leukocyte-adhesion molecules and leukocyte infiltration, peritoneal mast cells were also studied for their capacity to induce the expression of leukocyte-adhesion molecules in rat heart endothelial cells (RHEC). Peritoneal mast cells were used instead of cardiac mast cells, since isolation of the latter cells from the tissue usually results in low yield and high impurity. In the isolated, Langendorff-perfused rat heart, mast cells have been proposed to play a prominent role in acute hypoxia/reoxygenation-induced myocardial injury. However, considerable doubt existed about the techniques used in this study to quantitate the extent of mast cell degranulation. Therefore, we evaluated the role of mast cells in acute hypoxia/reoxygenation-induced injury to cardiomyocytes in this model, using histamine as a marker of mast cell degranulation. The role of mast cells in acute ischemia/reperfusion-induced injury to cardiomyocytes was also studied in the isolated, Langendorff-perfused rat heart.

\section{Peritoneal Mast Cells: Isolation and Quantification of The Degranulation Process}

Various techniques for the isolation of mast cells from the peritoneal cavity have been described. However, in most of the techniques, erythrocytes usually contaminate the final mast cell preparation. Since this might result in erroneous data concerning the fatty acid composition of mast cell phospholipids and the production of prostanoids and/or hydroxy fatty acids by mast cells (Chapter 3), a method to isolate mast cells in high purity was developed. Therefore, a two-step metrizamide-gradient was introduced into the original procedure of Schwartz et al. ${ }^{29}$ With this technique, peritoneal mast cells could be isolated in high quantity (mean mast cell count of about $8 \cdot 10^{5}$ cells per rat) and high purity (>99\%). In order to quantitate the extent of mast cell degranulation, a High Performance Liquid Chromatographic (HPLC) method for the determination of histamine was developed. Derivatization of the samples with fluorescamine resulted in samples which were stable over a period of at least a week, which had the advantage that samples needed not be immediately analyzed after derivatization. The method 
made use of an ordinary HPLC equipment, including a 'classical' reversed-phase octadecyl (C18) column for the separation of the compounds. At a later stage, the 'classical' reversed-phase HPLC column was replaced by an Inertsil ODS-2 column, which is characterized by a high carbon load and complete end-capping of the residual silanol groups. With this column, elution time, as well as peak tailing and broadening, were significantly reduced. ${ }^{30}$

\section{Mast Cell Activation and Mediator Release: Role of the Diet}

The role of membrane fatty acid composition in the formation of prostanoids and hydroxy fatty acids and in the degranulation process was studied. It was found that feeding rats different dietary fats caused major changes in the relative amounts of fatty acids in mast cell phospholipids. In general, a positive relation was found between the content of (n-6) precursor fatty acids in mast cell phospholipids and A23187-evoked production of prostanoids and hydroxy fatty acids (Chapter 3 ). This is in agreement with results with rat platelets, in which a strict relationship between the level of arachidonic acid in membrane phospholipids and the formation of hydroxyheptadecatrienoic acid $(\mathrm{HHT})$, a marker of thromboxane $\mathrm{B}_{2}$ formation, was shown. ${ }^{11}$ Despite considerable changes in the fatty acid composition of membrane phospholipids, no significant changes in compound $48 / 80$-induced histamine release were observed (Chapter 4 ). It was concluded that in mast cells, the fatty acid composition of membrane phospholipids was of importance in those cellular processes in which fatty acids actively participated, such as in the formation of prostanoids and hydroxy fatty acids, in which they served as substrates for cyclooxygenase and/or lipoxygenase, respectively. In those cases where fatty acids, as part of phospholipids in mast cell membranes, predominantly served to create a suitable environment for membrane-related processes, such as exocytosis, the fatty acid composition appeared to be less important. Comparable conclusions have drawn for cultured human umbilical vein endothelial cells (HUVEC). ${ }^{32,33}$ In the latter cells, it has been shown that considerable variation in fatty acid composition could be induced in all phospholipid classes by culturing the cells in medium to which specific fatty acids were added. The changes in membrane fatty acid composition strongly influenced the formation of eicosanoids, such as 6-keto-PGF $1 \alpha$ and $\mathrm{PGF}_{2 \alpha}$, but did not affect membrane-related processes, such as the adherence of polymorphonuclear cells to the endothelial cell monolayer or the shedding of procoagulant microvesicles. ${ }^{32,33}$

Despite major changes in the pattern of individual fatty acids in mast cell phospholipids, the average total amount of saturated (SAFA), monounsaturated (MUFA) and polyunsaturated fatty acids (PUFA) was kept within fairly narrow limits (Fig. 9.1). For instance, after feeding a mackerel oil diet, the increased contents of ( $n-3)$ fatty acids in mast cell phospholipids, such as timnodonic acid, 20:5(n-3), clupanodonic acid, 22:5(n3 ), and cervonic acid, 22:6(n-3), were accompanied by decreased contents of arachidonic acid, 20:4(n-6), and one of its elongation products, 22:4(n-6). In addition, no differences in the unsaturation index of the phospholipid fatty acids ${ }^{11}$ were observed between the three dietary groups $(133.7 \pm 4.9,130.9 \pm 5.6$ and $142.2 \pm 7.0$ in the 
$\mathrm{HCO}, \mathrm{SO}$ or MO-group, respectively). This suggests that in mast cells, the mean number of double bonds, and thus, physico-chemical properties of cellular membranes, are subject to a strong, 'homeostatic control'. Similar conclusions have been reached in HUVEC $^{32,33}$ and, more recently, in rat platelets. ${ }^{10}$

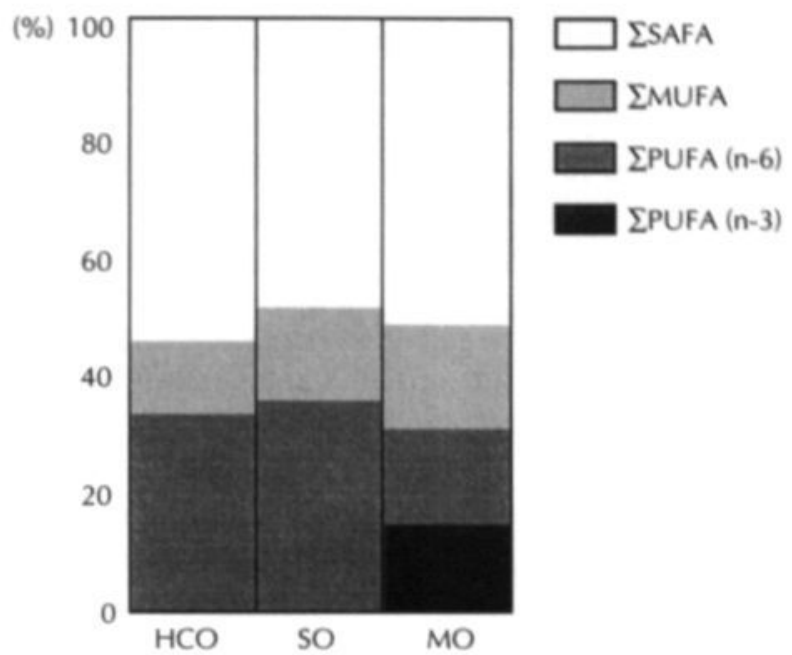

Figure 9.1: Global fatty acid composition of total phospholipids in mast cells from rats fed different diets. Mean weight percentages $(n=6)$ of saturated fatty acids (SAFA), monounsaturated fatty acids (MUFA) and polyunsaturated fatty acids (PUFA) are given. HCO: hydrogenated coconut oil; SO: sunflowerseed oil; MO: mackerel oil.

\section{Differential Release of Histamine and $\mathrm{PGD}_{2}$ : Roles of Cytosolic $\mathrm{Ca}^{2+}$ and Protein Tyrosine Kinases}

The role of the cytosolic $\mathrm{Ca}^{2+}$ concentration and protein tyrosine kinases in the differential release of histamine and $\mathrm{PGD}_{2}$ in mast cells was studied (Chapter 5). Cells were stimulated with the $G$ protein-activating compound $48 / 80$, which by activation of phospholipase $C_{\beta}\left(P L C_{\beta}\right)$, results in the formation of inositol trisphosphate $\left(\mathrm{IP}_{3}\right)$ and diacylglycerol (DAG, Fig. 9.2). $I P_{3}$ binds to a specific receptor $\left(I P_{3} R\right)$ and results in the release of $\mathrm{Ca}^{2+}$ from the internal stores. DAG, together with an increase in $\left[\mathrm{Ca}^{2+}\right]_{i}$, stimulates protein kinase C (PKC), which, in turn, phosphorylates various cellular proteins. Mast cells were also incubated in the presence of thapsigargin, which, by its inhibiting action on endomembrane $\mathrm{Ca}^{2+}$-ATPases, results in a PLC-independent increase in $\left[\mathrm{Ca}^{2+}\right]_{\mathrm{i}} \cdot{ }^{23,28}$ In addition, mast cells were stimulated with the $\mathrm{Ca}^{2+}$ ionophore ionomycin, or the $\mathrm{Mg}^{2+}$-free form of ATP, ATP4-, which, by binding to a specific $P_{2 y}$ receptor $\left(R_{1}\right)$, results in opening of receptor-operated channels (ROC). ${ }^{20}$

The results indicated that in mast cells, as in many other cells such as platelets 22,28 , the entry of $\mathrm{Ca}^{2+}$ across the plasma membrane was coupled to emptying of the intracellular $\mathrm{Ca}^{2+}$ stores. The most compelling evidence for this hypothesis came from the observation that inhibition of refilling of the $\mathrm{Ca}^{2+}$ stores by thapsigargin resulted in the influx of extracellular $\mathrm{Ca}^{2+}$. This notion was in agreement with results from 
electrophysiological studies in mast cells, in which depletion of the internal $\mathrm{Ca}^{2+}$ stores resulted in specific inward $\mathrm{Ca}^{2+}$ currents. ${ }^{12,21}$ The mechanism responsible for this, socalled, capacitive $\mathrm{Ca}^{2+}$ influx, is still far from clear. The results suggested that emptying of the internal $\mathrm{Ca}^{2+}$-stores was accompanied by the activation or generation of an unknown factor (Factor $\mathrm{X}$ ), which was responsible for the influx of $\mathrm{Ca}^{2+}$ through storeregulated channels (SRC, Fig. 9.2). Experiments in other cell types have indicated that a small diffusible messenger named CIF (Calcium Influx Factor) or a small G protein might be responsible for the capacitive $\mathrm{Ca}^{2+}$ influx. ${ }^{3,8,26}$ In general, the store-regulated $\mathrm{Ca}^{2+}$ influx promoted the release of histamine and $\mathrm{PGD}_{2}$, but the preference of each agonist to promote the release of histamine or $\mathrm{PGD}_{2}$ remained unchanged. Therefore, differences in agonist-induced rises in $\left[\mathrm{Ca}^{2+}\right]_{i}$ were considered not to be responsible for the differential release of histamine and $\mathrm{PGD}_{2}$ in mast cells.

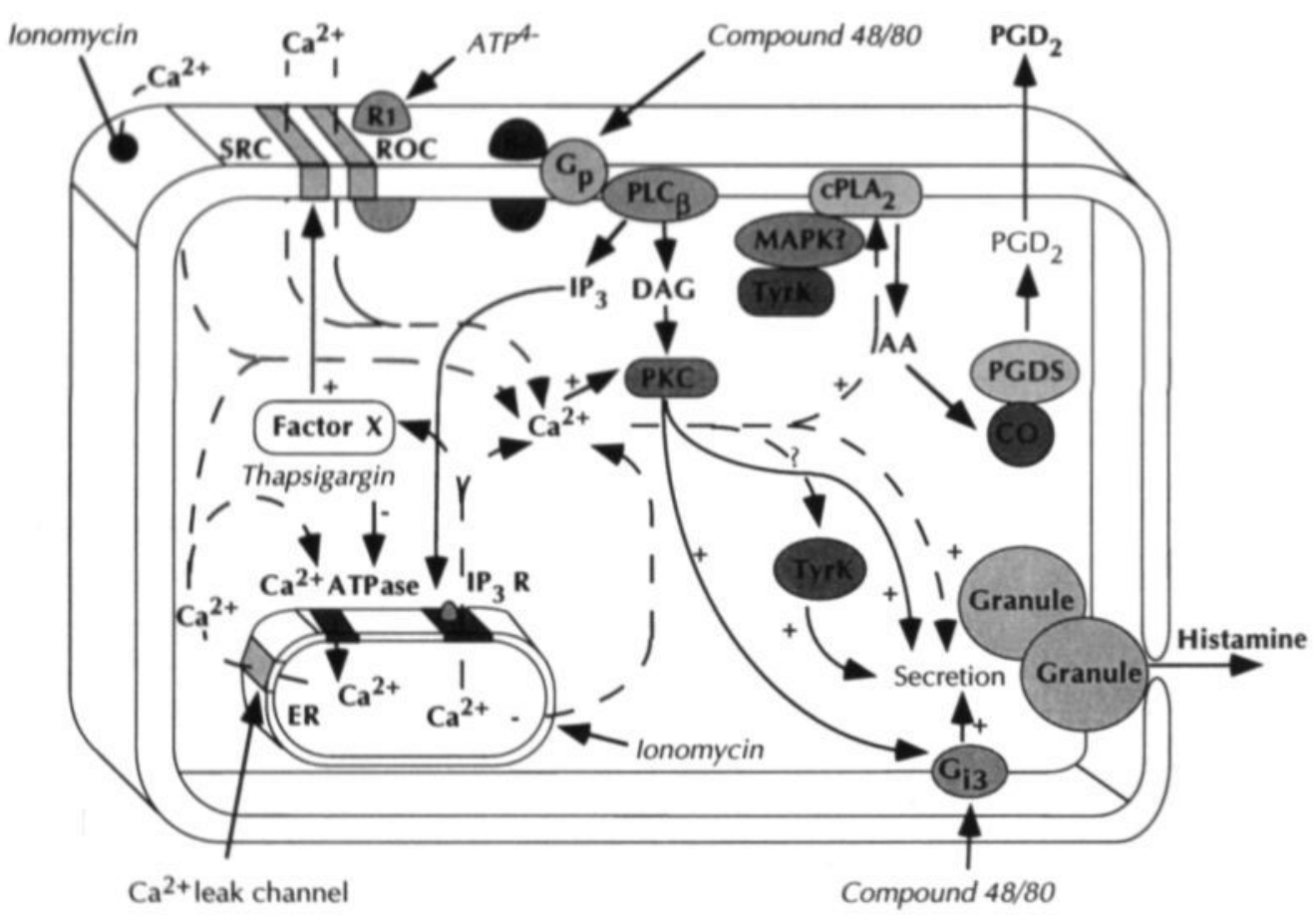

Figure 9.2: Schematic representation of signal transduction pathways in mast cells

SRC: store-regulated channel; ROC: receptor-operated channel; $R_{1}$ : receptor; Gp: GTP binding protein; PLC $C_{\beta}$ : phospholipase $C_{\beta}$; DAG: diacylglycerol; PKC: protein kinase $C_{\text {; }} I_{3}$ : inositol $(1,4,5)$ trisphosphate; TyrK: protein tyrosine kinase; MAPK: mitogen-activated protein kinase; $C P L A_{2}$ : cytosolic phospholipase $A_{2} ; A A$ : arachidonic acid; $C O$ : cyclooxygenase; PGDS: prostaglandin $D_{2}$ synthase; $P G D_{2}$ : prostaglandin $D_{2} ; I P_{3} R$ : inositol $(1,4,5)$ trisphosphate receptor; ER: endoplasmic reticulum

Besides its prominent role in $\mathrm{Ca}^{2+}$ influx, the results also indicated that (intracellular signaling events associated with) emptying of the $\mathrm{Ca}^{2+}$ stores was required to evoke a substantial release of histamine and $\mathrm{PGD}_{2}$. For instance, stimulation of mast cells with 
$\mathrm{CaCl}_{2}$ and $\mathrm{ATP}^{4-}$, or the addition of $\mathrm{CaCl}_{2}$ to store-depleted cells, resulted in a high increase in $\left[\mathrm{Ca}^{2+}\right]_{i}$, but in the release of only minor quantities of histamine and $\mathrm{PGD}_{2}$. Typically, in these cases, the increase in $\left[\mathrm{Ca}^{2+}\right]_{i}$ was solely evoked by the influx of extracellular $\mathrm{Ca}^{2+}$ and not by emptying of the internal $\mathrm{Ca}^{2+}$ stores. In contrast, in those conditions in which $\mathrm{Ca}^{2+}$ responses consisted of $\mathrm{Ca}^{2+}$ influx in combination with storeemptying, e.g., after stimulation of the cells with compound $48 / 80$, thapsigargin or ionomycin, a substantial release of histamine and $\mathrm{PGD}_{2}$ was observed. In platelets, it has been shown that the increase in $\left[\mathrm{Ca}^{2+}\right]_{i}$ caused by emptying of the internal $\mathrm{Ca}^{2+}$ stores, played a prominent role in tyrosine phosphorylation of specific cellular proteins, which, in turn, might regulate plasma membrane permeability for $\mathrm{Ca}^{2+},{ }^{34}$ We found that protein tyrosine kinases were involved in both the release of histamine and $\mathrm{PGD}_{2}$. Hence, it is possible that in mast cells, emptying of the $\mathrm{Ca}^{2+}$ stores is related to activation of protein tyrosine kinases, which may explain the effects of inhibitors of these kinases on the release of histamine and $\mathrm{PGD}_{2}$. The exact mechanisms by which protein tyrosine kinases in mast cells are activated are largely unknown, and, therefore remain to be clarified.

Although we did not measure protein phosphorylation patterns directly, our data suggested that in mast cells, protein tyrosine kinases were more prominently involved in the process of eicosanoid formation than in exocytosis. Experiments with store-depleted mast cells indicated that, besides protein tyrosine kinases, prolonged high levels of $\left[\mathrm{Ca}^{2+}\right]_{i}$ might also play an important role in promoting the formation of $\mathrm{PGD}_{2}$. The high histamine secretion evoked by compound $48 / 80$, is known to be due to the activation of protein kinase $C^{9,21}$ and/or the newly identified protein, $G_{i 3}{ }^{2}$ Judging from the results in other cell types, protein tyrosine kinases might play an important role in activation of mitogen-activated kinases (MAP kinases) ${ }^{15,18}$, which, together with an increase in $\left[\mathrm{Ca}^{2+}\right]_{i}^{4,5}$, result in activation of cytosolic phospholipase $\mathrm{A}_{2}\left(\mathrm{CPLA}_{2}\right)$. This enzyme has been shown to be responsible for agonist-evoked release of arachidonic acid (AA) in most cell types. ${ }^{15,17}$

\section{Mast Cells and Injury to Cardiomyocytes}

Results from in vivo and ex vivo studies have indicated that mast cells play a role in ischemia/reperfusion or hypoxia/reoxygenation-induced myocardial injury. ${ }^{13,14}$ Much of this evidence is based on the stabilizing effects of lodoxamide on myocardial mast cells. In order to study the role of mast cells in ischemia/reperfusion-induced injury to cardiomyocytes in a more direct way, hearts, isolated from sensitized and non-sensitized rats $^{31}$, were perfused according to Langendorff. Previously, it has been shown that antigen-challenge resulted in a massive mast cell degranulation in sensitized hearts ${ }^{31}$, a phenomenon which is absent in non-sensitized, control hearts. 'Mast cell-depleted' and control hearts were subjected to short-term ischemia/reperfusion. It was found that during normoxic perfusion, a massive mast cell degranulation was not followed by an increased release of lactate dehydrogenase (LDH) and, thus, did not result in (irreversible) injury to cardiomyocytes. During reperfusion, LDH release in previously ischemic control hearts was equal to that in 'mast cell-depleted' hearts. Therefore, the 
results provided no evidence that mast cells were prominently involved in acute ischemia/reperfusion-induced injury to cardiac muscle cells. In a hypoxia/reoxygenation model of myocardial injury, it was found that the release of histamine, used as a marker of mast cell degranulation, did not correlate to that of LDH or creatine kinase (CK). In addition, no correlation between the release of histamine and that of peroxidase (PO), a proposed marker of mast cell degranulation ${ }^{14}$, was observed. Determination of POactivity in isolated cardiomyocytes revealed that in the rat heart, the bulk of PO-activity was located in these cells. The results showed that the conclusion of Keller et al. ${ }^{14}$ on the role of mast cells in acute hypoxia/reoxygenation-induced injury to cardiomyocytes, was based on the incorrect use of PO as a marker of mast cell degranulation. In fact, the results indicated that in the isolated rat heart, mast cell degranulation was not related to the extent of injury to cardiomyocytes, both in the case of ischemia/reperfusion, when this injury was relatively low (Chapter 6) and in hypoxia/reoxygenation, when the injury was high (Chapter 7 . Although the models differed at some points from the situation in vivo (no blood cells, no innervation), it was concluded that there was no evidence that in vivo products released from degranulated mast cells were directly involved in acute ischemia/reperfusion-induced injury to cardiomyocytes.

\section{Mast cells and the Induction of Endothelial Leukocyte-Adhesion Molecules}

Data from in vitro studies in which rat heart endothelial cells were used (Chapter 8 ), indicated that longer-term effects of mast cell-derived products might include the infiftration of feukocytes into cardiac tissue. It was found that both under conditions in which mast cells were in direct contact with endothelial cells (contact studies) and in conditions in which they were separated from endothelial cells through a permeable membrane (transwell studies), products released from mast cells increased the expression of VCAM-1 and E-selectin, and to a lesser extent, ICAM-1, by endothelial cells. These molecules play a prominent role in the adhesion of leukocytes to the vascular endothelium, a necessary first-step in leukocyte migration. ${ }^{1}$ The expression of VCAM-1 and E-selectin was highest when mast cells were in direct contact with endothelial cells. This suggested that in these conditions high local concentrations of mast cell-derived mediators were achieved. However, it could not be excluded that direct 'cell-cell' interactions between mast cells and endothelial cells were responsible for (part of) the observed effects. The expression of VCAM-1 and E-selectin by endothelial cells was not related to mast cell degranulation, which indicated that the expression of these leukocyte-adhesion molecules was evoked by (a) mediator(s) constitutively released from mast cells. The nature of this (these) mediator(s) is unknown, but the results indicated that at least histamine could be excluded from the list of putative mast cell-derived products. Since, under normal physiological conditions in vivo, continuous expression of E-selectin and VCAM-1 is not observed, the responsible mast cell-derived mediator(s) was (were) considered to be little effective in the direct induction of these endothelial leukocyte-adhesion molecules. Possibly, in vivo, the mediator(s) is (are) rapidly degraded or effused, preventing high local concentrations. Alternatively, it was proposed that the mast cell-derived mediator(s) might serve to 
increase the sensitivity of endothelial cells to triggers locally generated by cells other than mast cells or by the endothelium itself. Another possibility is that in vivo, products released from cells residing in the vicinity of mast cells, such as cardiomyocytes, inhibit the formation and/or release or the effects of mast cell-derived mediator(s). In this context, it was speculated that during ischemia/reperfusion, in which the inhibitory effects of cardiac muscle cells on mast cells might be decreased or lost, the release of mast cell-derived mediators could contribute to the infiltration of leukocytes into cardiac tissue by promoting the expression of VCAM-1 and E-selectin. Since the infiltration of leukocytes after ischemia/reperfusion is closely related to the extent of myocardial injury $7,16,27$, it is tempting to speculate that mast cells contribute to this kind of injury by increasing the expression of endothelial leukocyte-adhesion molecules. Besides negative effects of mast cells in longer-term injury in the heart, it cannot be excluded that mast cells also exert positive effects. For instance, it has been shown that in a model of prolonged ischemia ( 3 weeks), mast cells accumulate in the subepicardial layer of the infarcted region. ${ }^{6}$ Since these cells are prominently involved in angiogenesis $19,24,25$, this may be of importance in prevention of further irreversible injury to myocardial tissue.

\section{REFERENCES}

1. Adams, D.H. and Shaw, S. (1994) Leukocyte-endothelial interactions and regulation of leukocyte migration: a review. The Lancet 343, 831-836.

2. Aridor, M., Rajmilevich, G., Beaven, M.A. and Sagi-Eisenberg, R. (1993) Activation of exocytosis by the heterotrimeric $G$ protein $G_{i 3}$. Science 262, 1569-1571.

3. Bird, G.S.J. and Putney, J.W. (1993) Inhibition of thapsigargin-induced calcium entry by microinjected guanine nucleotide analogues. Evidence for the involvement of a small $G$ protein in capacitative calcium entry. I Biol Chem 268, 21486-21488.

4. Channon, J.Y. and Leslie, C.C. (1990) A calcium-dependent mechanism for associating a soluble arachidonoyl-hydrolyzing phospholipase $A_{2}$ with membrane in the macrophage cell line $R A W$ 264.7. J Biol Chem 265, 5409-5413.

5. Clark, J.D., Lin, L.-L., Kriz, R.W., Ramesha, C.S., Sultzman, L.A., Lin, A.Y., Milona, N. and Knopf, J.L. (1991) A novel arachidonic acid-selective cytosolic PLA 2 contains a $\mathrm{Ca}^{2+}$ dependent translocation domain with homology to PKC and GAP. Cell 65, 1043-1051.

6. Engels, W., Reiters, P.H.C.M., Daemen, M.J.A.P., Smits, J.F.M. and Van der Vusse, G.J. (1995) Transmural changes in mast cell density in rat heart after infarct induction in vivo. I Pathol (accepted for publication).

7. Engler, R.L., Dahlgren, M.D., Morris, D.D., Peterson, M.A. and Schmid-Schonbein, G.W. (1986) Role of leukocytes in response to acute myocardial ischemia and reflow in dogs. Am J Physiol 251, $\mathrm{H} 314-\mathrm{H} 323$.

8. Fasalato, C., Hoth, M. and Penner, R. (1993) A GTP-dependent step in the activation mechanism of capacitative calcium influx. J Biol Chem 268, 20737-20740.

9. Gomperts, B.D. (1991) Intracellular mechanisms regulating exocytotic secretion in mast cells. Int Arch Appl Imm 94, 38-46.

10. Heemskerk, J.W.M., Feijge, M.A.H., Simonis, M.A.G. and Hornstra, G. (1995) Effects of dietary fatty acids on signal transduction and membrane cholesterol content in rat platelets. Biochim Biophys Acta 1255, 87-97.

11. Hornstra, G. (1982) Dietary fats, prostanoids and arterial thrombosis. In: Effect of type and amount of dietary fats on arterial thrombus formation Martinus Nijhoff Publishers, The Hague/Boston/London.

12. Hoth, M. and Penner, R. (1992) Depletion of intracellular calcium stores activates a calcium current in mast cells. Nature 355, 353-356.

13. Jolly, S.R., Abrams, G.D., Romson, J.L., Baillie, M.B. and Lucchesi, B.R. (1982) Effects of lodoxamide on ischemic reperfused myocardium. J Cardiovasc Pharmacol 4, 441-448. 
14. Keller, A.M., Clancy, R.M., Barr, M.L., Marboe, C.C. and Cannon, P.J. (1988) Acute reoxygenation injury in the isolated rat heart: role of resident cardiac mast cells. Circ Res 63 , 1044-1052.

15. Lin, L.L., Wartmann, M., Lin, A.Y., Knopf, J.L., Seth, A. and Davis, R.J. (1993) $c P L A_{2}$ is phosphorylated and activated by MAP kinase. Cell 72, 269-278.

16. Mullane, K.M., Read, N., Salmon, J.A. and Moncada, S. (1984) Role of leukocytes in acute myocardial infarction in anesthetized dogs. Relationship to myocardial salvage by antiinflammatory drugs. J Pharmacol Exp Ther 228, 510-522.

17. Murakami, M., Kudo, I., Umeda, M., Matsuzawa, A., Takeda, M., Komada, M., Fujimori, Y., Takahashi, K. and Inoue, K. (1992) Detection of three distinct phospholipases $A_{2}$ in cultured mast cells. J Biochem 111, 175-181.

18. Nemenoff, R.A., Winitz, S., Qian, N., Van Putten, V., Johnson, G.L. and Heasley, L.E. (1993) Phosphorylation and activation of a high molecular weight form of phospholipase $A_{2}$ by 042 microtubule-associated protein 2 kinases and protein kinase C. J Biol Chem 268, 1960-1964.

19. Norrby, K., Jakobsson, A. and Sorbo, J. (1986) Mast cell mediated angiogenesis: a novel experimental model using the rat mesentery. Cell Pathol 52, 195-206.

20. Osipchuk, Y. and Cahalan, M. (1992) Cell-to-cell spread of calcium signals mediated by ATP receptors in mast cells. Nature 359, 241-244.

21. Penner, R. (1988) Multiple signaling pathways control stimulus-secretion coupling in rat peritoneal mast cells. Proc Natl Acad Sci USA 85, 9856-9860.

22. Putney, J., J.W. and Bird, G. (1993) The signal for capacitive calcium entry. Cell 75, 199-201.

23. Putney, J.W. and Bird, G.J. (1993) The inositol phosphate-calcium signaling system in nonexcitable cells. Endocrin Revi 14, 610-631.

24. Rakusan, K. and Campbell, S.E. (1991) Spatial relationship between cardiac mast cells and coronary capillaries in neonatal rats with cardiomegaly. Can J Physiol 69, 1750-1753.

25. Rakusan, K., Sarkar, K., Turek, Z. and Wicker, P. (1990) Mast cells in the rat heart during normal growth and in cardiac hypertrophy. Circ Res 66, 511-516.

26. Randriamampita, C. and Tsien, R.Y. (1993) Emptying of intracellular $\mathrm{Ca}^{2+}$ stores releases a novel small messenger that stimulates $\mathrm{Ca}^{2+}$ influx. Nature 364, 809-814.

27. Romson, J.L., Hook, B.G., Kunkel, S.L., Abrams, G.D., Schork, M.A. and Lucchesi, B.R. (1983) Reduction of the extent of ischemic myocardial injury by neutrophil depletion in the dog. Circulation 67, 1016-1023.

28. Sargeant, P., Clarkson, W.D., Sage, S.O. and Heemskerk, J.W.M. (1992) Calcium influx evoked by $\mathrm{Ca}^{2+}$ store depletion in human platelets is more susceptible to cytochrome P-450 inhibitors than receptor-mediated calcium entry. Cell Calcium 13, 553-564.

29. Schwartz, L.B., Austen, K.F. and Wasserman, S.I. (1979) Immunologic release of $\beta$ hexosaminidase and $\beta$-glucuronidase from purified rat serosal mast cells. J Immunol 123, 14451450.

30. Van Haaster, C.M.C.J., Engels, W., Lemmens, P.J.M.R., Hornstra, G. and Van der Vusse, G.J. (1994) Rapid and highly sensitive high-performance liquid chromatographic method for the determination of histamine and 3-methyl histamine in biological samples using fluorescamine as the derivatizing agent. J Chromatr 657, 261.

31. Vleeming, W., Rooij, H.H., Wemer, J. and Porsius, A.J. (1991) Characterization and modulation of antigen-induced effects in the isolated rat heart. J Cardiovasc Pharmacol 18, 556-565.

32. Vossen, R.C.R.M. (1993) Fatty acid modification and endothelial cell reactivity. Maastricht: Thesis University of Limburg.

33. Vossen, R.C.R.M., Van Dam-Mieras, M.C.E., Lemmens, P.J.M.R., Hornstra, G. and Zwaal, R.F.A. (1991) Membrane fatty acid composition and endothelial cell functional properties. Biochim Biophys Acta 1083, 243-251.

34. Vostal, J.G., Jackson, W.L. and Shulman, N.R. (1991) Cytosolic and stored calcium antagonistically control tyrosine phosphorylation of specific platelet proteins. J Biol Chem 266, 16911-16916. 
| SUMMARY 
In this thesis, the role of mast cells in acute ischemia/reperfusion and hypoxia/ reoxygenation-induced injury to cardiomyocytes is described. This was studied in the isolated, Langendorff-perfused rat heart. In addition, various specific aspects of mast cell activation and mediator release, such as the roles of membrane fatty acid composition, the cytosolic $\mathrm{Ca}^{2+}$ concentration and protein tyrosine kinases in the release of histamine and prostanoids, are described. The latter aspects were studied in peritoneal mast cells.

Some general aspects of mast cell activation and mediator release are discussed in Chapter 1. Mast cells are inflammatory cells found in various tissues such as lung, heart and skin. Mediators released from these cells play an important role in the clinical signs of hay-fever and asthma. In their secretory granules, mast cells contain a large variety of mediators, such as histamine, which are rapidly released upon activation. In addition, mast cells release a variety of newly formed mediators such as prostanoids and hydroxy fatty acids. In order to quantitate the extent of mast cell degranulation, a rapid and highly sensitive High Performance Liquid Chromatographic (HPLC) method for the determination of histamine in biological samples was developed. This technique was used to determine the amounts of histamine in cardiac tissue, coronary effluents and supernatants of stimulated peritoneal mast cells. Since in most of the techniques for the isolation of peritoneal mast cells described until now, erythrocytes contaminate the final mast cell preparation, a method was developed to isolate these cells from the peritoneal cavity in high purity. This method and the HPLC procedure for the determination of histamine are described in Chapter 2.

Certain fatty acids incorporated in membrane phospholipids, such as linoleic or arachidonic acid, serve as precursors for the synthesis of prostanoids and hydroxy fatty acids. We were interested to know to which extent diet-induced changes in mast cell membrane fatty acid composition influenced the formation of prostanoids and hydroxy fatty acids. Therefore, peritoneal mast cells were isolated from rats fed diets which differed in their fatty acid composition (Chapter 3). It was found that the formation of prostanoids and hydroxy fatty acids was strongly influenced by diet-induced changes in mast cell phospholipid fatty acid composition. We hypothesized that diet-induced changes in mast cell phospholipid fatty acid composition might influence membranerelated processes such as exocytosis (Chapter $\mathbf{4}$ ). Although the different dietary fats induced major changes in the fatty acid composition of mast cell phospholipids, no differences in compound $48 / 80$-induced histamine release were observed. It was concluded that the extent of mast cell degranulation was independent of the fatty acid composition of membrane phospholipids.

In Chapter 5, the role of the cytosolic $\mathrm{Ca}^{2+}$ concentration and protein tyrosine kinases in the differential release of histamine and $\mathrm{PGD}_{2}$ in mast cells is described. Mast cells were stimulated with the G protein-activating compound $48 / 80$, with thapsigargin, an inhibitor of endomembrane $\mathrm{Ca}^{2+}$-ATPases, with the $\mathrm{Ca}^{2+}$ ionophore ionomycin or with the $\mathrm{Mg}^{2+}$-free form of ATP, ATP4-. It was found that stimulation of the cells with compound $48 / 80$ evoked a high histamine secretion and a low $\mathrm{PGD}_{2}$ release, whereas the $\mathrm{Ca}^{2+}$ mobilizers thapsigargin and ionomycin evoked a low histamine secretion and a high release of $\mathrm{PGD}_{2}$. Despite prolonged high levels of $\left[\mathrm{Ca}^{2+}\right]_{i}, \mathrm{ATP}{ }^{4-}$ did not evoke a 
substantial release of histamine or $\mathrm{PGD}_{2}$. In the absence of extracellular $\mathrm{CaCl}_{2}$, i.e., in those cases in which the influx of extracellular $\mathrm{Ca}^{2+}$ was absent, agonist-induced rises in $\left[\mathrm{Ca}^{2+}\right]_{i}$ as well as histamine secretion and $\mathrm{PGD}_{2}$ release were significantly reduced. In addition, it was found that the release of histamine was much more influenced by inhibitors of protein tyrosine kinases than the release of $\mathrm{PGD}_{2}$. It was concluded that the store-regulated influx of extracellular $\mathrm{Ca}^{2+}$ amplified agonist-induced rises in $\left[\mathrm{Ca}^{2+}\right]_{i}$ as well as histamine secretion and $P G D_{2}$ release. The differential release of histamine and $\mathrm{PGD}_{2}$ appeared not to be due to differences in the increase in $\left[\mathrm{Ca}^{2+}\right]_{\mathrm{i}}$, but rather to a different involvement of protein tyrosine kinases in both processes.

The heart has been shown to contain a resident population of mast cells of which the (patho-)physiological role is largely unknown. It has been suggested that in the heart ex vivo, mast cells play a role in hypoxia/reoxygenation-induced injury to cardiac muscle cells. However, there is considerable doubt about the marker used to quantitate the extent of mast cell degranulation. Mast cells have also been proposed to play a role in ischemia/reperfusion-induced myocardial injury in vivo. We firstly studied to which extent mast cells were involved in acute ischemia/reperfusion-induced injury to cardiomyocytes (Chapter 6). Therefore, hearts isolated from non-sensitized, control rats or sensitized rats, were perfused according to Langendorff. During normoxic perfusion, hearts were challenged with antigen, a procedure which is known result in a massive mast cell degranulation in sensitized hearts. After $20 \mathrm{~min}$, hearts were subjected to 30 min of global ischemia followed by $30 \mathrm{~min}$ of reperfusion. Since injury to cardiomyocytes results in a rapid leakage of lactate dehydrogenase (LDH), the activity of this enzyme was determined in coronary effluents in order to quantitate the extent of irreversible damage to these cells. During reperfusion, no differences in LDH release between control hearts and 'mast cell-depleted hearts' were found. Thus, the results provided no evidence that in this model, mast cells were prominently involved in acute ischemia/reperfusion-induced injury to cardiomyocytes.

The role of mast cells in acute hypoxia/reoxygenation-induced injury to cardiomyocytes was studied using histamine as a marker of mast cell degranulation (Chapter 7). Isolated, Langendorff-perfused rat hearts were subjected to $35 \mathrm{~min}$ of normoxic perfusion, followed by $60 \mathrm{~min}$ of hypoxic perfusion and $30 \mathrm{~min}$ of reoxygenation. The activities of $\mathrm{LDH}$ or creatine kinase (CK) were determined in coronary effluents in order to quantitate the extent of (irreversible) injury cardiomyocytes. Special attention was paid to the suitability of peroxidase (PO) as a marker of mast cell degranulation. During reoxygenation, the release of $\mathrm{LDH}, \mathrm{CK}$ and PO did not correlate to that of histamine. When hearts were perfused in the presence of the mast cell stabilizer lodoxamide, histamine release during reoxygenation significantly decreased, whereas the release of $\mathrm{LDH}, \mathrm{CK}$ or $\mathrm{PO}$ remained unchanged. Determination of PO-activity in isolated cardiomyocytes learned that the bulk of POactivity in the heart was located in these cells and not in mast cells. Therefore, it was concluded that in the isolated rat heart, PO release was not a suitable marker to indicate the extent of mast cell degranulation. In addition, the results provided no evidence that in this model, mast cells were prominently involved in the extent of acute hypoxia/reoxygenation-induced injury to cardiomyocytes. 
In tissues such as rat mesenterium and hamster cheeck pouch, products released from mast cells have been found to play a prominent role in the expression of endothelial leukocyte-adhesion molecules and leukocyte infiltration. In the process of leukocyte-adhesion, the interaction between endothelial leukocyte-adhesion molecules, such as ICAM-1, VCAM-1 and E-selectin with their respective counterparts on circulating leukocytes is an important step. Until now, information about the role of mast cells in the adhesion of leukocytes to cardiac endothelium is lacking. The role of mast cells in the induction of endothelial leukocyte-adhesion molecules in the heart in vivo was approached in an in vitro rat experimental model (Chapter 8). Peritoneal mast cells were studied for their capacity to induce the expression of ICAM-1, VCAM-1 and E-selectin in cultured endothelial cells. For ICAM-1 and VCAM-1 studies, rat heart endothelial cell (RHEC) lines were used. For E-selectin studies, human umbilical vein endothelial cells (HUVEC) were used, since no suitable rat E-selectin antibodies for the rat system were available. Mast cells were incubated either in direct cell-cell contact with endothelial cells or were separated from these cells through a permeable membrane. It was found that in both conditions, products released from mast cells increased the expression of VCAM-1 and E-selectin, and to a minor extent, that of ICAM-1 in endothelial cells. The direct contact between mast cells and endothelial cells significantly promoted the expression of these leukocyte-adhesion molecules. It was concluded that the induction of ICAM-1, VCAM-1 and E-selectin by endothelial cells was not related to the extent of mast cell degranulation, but seemed to be evoked by the release of $a(n)$, so far, undefined substance(s) other than histamine, constitutively released from mast cells.

In Chapter 9 the results described in this thesis are summarized and discussed in a broader perspective. 
| SAMENVATting 
In dit proefschrift wordt de rol van mestcellen in acute ischemie/reperfusie en hypoxie/reoxygenatie-geïnduceerde schade aan hartspiercellen beschreven. Dit werd bestudeerd in het geïsoleerde, Langendorff-geperfundeerde rattehart. Tevens worden enkele aspecten van mestcel-activatie en het vrijstellen van mediatoren beschreven. Met name op de rol van de vetzuursamenstelling van het celmembraan, de intracellulaire calcium concentratie en tyrosine kinases in de vrijstelling van histamine en prostanoïden wordt nader ingegaan. Deze laatste aspecten werden bestudeerd in peritoneale mestcellen.

Enkele algemene aspecten van mestcellen en het vrijstellen van mediatoren worden beschreven in Hoofdstuk 1. Mestcellen zijn ontstekingscellen die in verschillende weefsels, zoals long, hart en huid worden aangetroffen. Mediatoren die door deze cellen vrijgesteld worden, spelen een belangrijke rol in de klinische verschijnselen van hooikoorts en astma. In de granules van deze cellen bevinden zich vele mediatoren, zoals histamine, die snel vrijgesteld kunnen worden als de cel wordt geactiveerd. Tevens kunnen mestcellen een aantal mediatoren vrijstellen, die nieuw door de cel worden gemaakt, zoals bijvoorbeeld de prostanoïden en hydroxyvetzuren. Om de mate van mestceldegranulatie te kwantificeren, werd een methode ontwikkeld om de hoeveelheid histamine in biologische monsters te bepalen. Deze methode, die gebruik maakt van hoge druk vloeistofchromatografie (HPLC), werd gebruikt om de hoeveelheid histamine in hartspierweefsel, coronaire effluenten en supernatanten van gestimuleerde mestcellen te bepalen. Omdat in de meeste methodes voor de isolatie van peritoneale mestcellen die tot nu beschreven zijn, erythrocyten meestal in het uiteindelijke mestcelpreparaat aanwezig zijn, werd een methode ontwikkeld om mestcellen in hoge zuiverheid uit de buikholte te isoleren. Deze procedure en de HPLC methode voor de bepaling van histamine worden beschreven in Hoofdstuk 2.

Bepaalde vetzuren die ingebouwd zijn in membraanfosfolipiden, zoals linolzuur of arachidonzuur, kunnen worden gebruikt voor de synthese van prostanoìden en hydroxyvetzuren. Wij onderzochten in hoeverre de vorming van prostanoïden en hydroxyvetzuren in mestcellen beïnvloed werd door dieet-geïnduceerde veranderingen in de vetzuursamenstelling van membraanfosfolipiden. Daarom werden peritoneale mestcellen geïsoleerd uit ratten die gevoed waren met diëten van een verschillende vetzuursamenstelling (Hoofdstuk 3). Het bleek dat de vorming van prostanoïden en hydroxyvetzuren in mestcellen sterk beïnvloed werd door dieetgeïnduceerde veranderingen in de vetzuursamenstelling van membraanfosfolipiden. In Hoofdstuk 4 wordt de rol van de vetzuursamenstelling van membraanfosfolipiden in de mate van mestceldegranulatie beschreven. Ondanks dat de verschillende dieetvetten belangrijke veranderingen in de vetzuursamenstelling van mestcelfosfolipiden induceerden, werden er geen belangrijke veranderingen waargenomen in de mate van compound 48/80-geïnduceerde vrijstelling van histamine. Daarom werd geconcludeerd dat de mate van mestceldegranulatie onafhankelijk was van de vetzuursamenstelling van membraanfosfolipiden.

In Hoofdstuk 5 wordt de rol van de intracellulaire $\mathrm{Ca}^{2+}$ concentratie en tyrosine kinases in de differentiële vrijstelling van histamine en $\mathrm{PGD}_{2}$ in mestcellen beschreven. Mestcellen werden gestimuleerd met het $\mathrm{G}$ eiwit-activerende compound 48/80, met 
thapsigargine, een remmer van $\mathrm{Ca}^{2+}$-ATPases, met de $\mathrm{Ca}^{2+}$ ionofoor ionomycine of met de $\mathrm{Mg}^{2+}$-vrije vorm van ATP, ATP4-. Activatie met compound $48 / 80$ resulteerde in een hoge vrijstelling van histamine en een lage vrijstelling van $\mathrm{PGD}_{2}$, terwijl activatie met thapsigargine of ionomycine resulteerde in een lage vrijstelling van histamine en een relatief hoge vrijstelling van $\mathrm{PGD}_{2}$. Ondanks langdurig hoge intracellulaire $\mathrm{Ca}^{2+}$ concentraties $\left(\left[\mathrm{Ca}^{2+}\right]_{i}\right)$, resulteerde incubatie met ATP4- niet in een substantiële vrijstelling van histamine of $\mathrm{PGD}_{2}$. In de afwezigheid van extracellulair $\mathrm{CaCl}_{2}(=$ in de afwezigheid van influx van extracellulair $\mathrm{Ca}^{2+}$ ), daalden de agonist-geïnduceerde toenames in $\left[\mathrm{Ca}^{2+}\right]_{i}$ en de vrijstelling van histamine en $\mathrm{PGD}_{2}$. Het bleek dat de vrijstelling van $\mathrm{PGD}_{2}$ veel sterker beïnvloed werd door remmers van tyrosine kinases dan de vrijstelling van histamine. Er werd geconcludeerd dat de influx van extracellulair $\mathrm{Ca}^{2+}$ zowel de agonist-geïnduceerde stijgingen van $\left[\mathrm{Ca}^{2+}\right]_{i}$ als de vrijstelling van histamine en $\mathrm{PGD}_{2}$ verhoogde. De differentiële vrijstelling van histamine en $\mathrm{PGD}_{2}$ bleek niet afhankelijk van verschillende stijgingen van $\left[\mathrm{Ca}^{2+}\right]_{i}$, maar eerder van een verschillende rol van tyrosine kinases in beide processen.

Het hart bevat een residente populatie van mestcellen, waarvan de pathofysiologische rol vrijwel onbekend is. Resultaten van een ex vivo studie hebben gesuggereerd dat mestcellen een rol zouden kunnen spelen in acute hypoxie/reoxygenatie-geïnduceerde schade aan hartspiercellen. Er bestaat echter grote twijfel over de maat die gebruikt werd om de mate van mestceldegranulatie te kwantificeren. Er zijn aanwijzingen dat mestcellen ook een rol spelen in ischemie/reperfusie-geïnduceerde hartspierschade in vivo. Wij hebben allereerst bestudeerd in hoeverre mestcellen een rol spelen in acute ischemie/reperfusiegeïnduceerde schade aan hartspiercellen (Hoofdstuk 6). Harten die geïsoleerd waren uit niet-gesensitiseerde, controle ratten of uit gesensitiseerde ratten werden geperfundeerd volgens Langendorff. Gedurende de normoxische perfusie werd aan alle harten antigeen toegediend, waarvan bekend is dat het leidt tot een massale mestceldegranulatie in gesensitiseerde harten. $\mathrm{Na} 20 \mathrm{~min}$ normoxische perfusie werden alle harten onderworpen aan $30 \mathrm{~min}$ ischemie gevolgd door $30 \mathrm{~min}$ reperfusie. Omdat schade aan hartspiercellen leidt tot het lekken van lactaat dehydrogenase (LDH), werd de activiteit van dit enzym bepaald in coronaire effluenten om de mate van irreversibele schade aan deze cellen te kwantificeren. Tijdens de reperfusie-fase werden geen verschillen waargenomen in de mate van LDH-vrijstelling tussen de controle en de gesensitiseerde harten. De resultaten leverden geen bewijs dat mestcellen in dit model een belangrijke rol speelden in de mate van acute ischemie/reperfusie-geïnduceerde schade aan hartspiercellen.

De rol van mestcellen in acute hypoxie/reoxygenatie-geïnduceerde schade aan hartspiercellen werd bestudeerd door histamine als maat voor mestceldegranulatie te gebruiken (Hoofdstuk 7). Geïsoleerde, Langendorff-geperfundeerde harten werden onderworpen aan 35 minuten normoxische perfusie, gevolgd door 60 minuten hypoxische perfusie en 30 minuten reoxygenatie. De activiteiten van $\mathrm{LDH}$ en creatine kinase (CK) werden bepaald in coronaire effluenten om de mate van irreversibele schade aan hartspiercellen te kwantificeren. Speciale aandacht werd besteed aan de geschiktheid van peroxidase (PO) als maat voor mestceldegranulatie. Gedurende de 
reoxygenatie-fase werd geen correlatie gevonden tussen de vrijstelling van $\mathrm{LDH}, \mathrm{CK}$ en $\mathrm{PO}$, en de mate van histamine vrijstelling. Wanneer harten geperfundeerd werden in de aanwezigheid van de mestcelstabilisator lodoxamide, daalde gedurende de reoxygenatie-fase de vrijstelling van histamine, maar de vrijstelling van $\mathrm{LDH}, \mathrm{CK}$ en PO bleef onveranderd. Bepaling van de PO-aktiviteit in geïsoleerde hartspiercellen toonde aan de meerderheid van PO-aktiviteit in het hart gelokaliseerd was in deze cellen en niet in mestcellen. Daarom werd geconcludeerd dat de vrijstelling van PO in dit model geen geschikte maat was om de mate van mestceldegranulatie te bepalen. Tevens leverden deze resultaten geen bewijs dat mestcellen een belangrijke rol spelen in de mate van acute hypoxie/reoxygenatie-geïnduceerde schade aan hartspiercellen.

In weefsels, zoals het mesenterium van de rat of de hamster-wangzak, is het aangetoond, dat mediatoren die vrijgesteld worden door mestcellen betrokken zijn in de expressie van leukocyt-adhesie moleculen en leukocyt-infiltratie. In het proces van leukocyt-adhesie speelt de interactie tussen endotheliale leukocyt-adhesie moleculen, zoals ICAM-1, VCAM-1 en E-selectine met hun respectievelijke liganden op circulerende leukocyten, een belangrijke rol. Tot nu toe is er niets bekend over de rol van mestcellen in de adhesie van leukocyten aan hart endotheel. De rol van mestcellen in de inductie van endotheliale leukocyt-adhesie moleculen in vivo, werd bestudeerd in een in vitro rat experimenteel model (Hoofdstuk 8). Daartoe werd gekeken in hoeverre peritoneale mestcellen in staat waren om de expressie van ICAM-1, VCAM-1 of E-selectine op gekweekte endotheelcellen te induceren. Voor ICAM-1 en VCAM-1 studies werden lijnen van rattehart endotheelcellen (RHEC) gebruikt, terwijl voor de Eselectine studies humane navelstreng endotheelcellen (HUVEC) werden gebruikt, omdat E-selectine antilichamen voor het rat-systeem niet beschikbaar waren. Mestcellen werden geïncubeerd in direct 'cel-cel' contact met endotheelcellen of ze werden van deze cellen gescheiden door middel van een permeabel membraan. Het bleek dat in beide condities, stoffen die door mestcellen werden vrijgesteld, de expressie van VCAM-1 en E-selectine, en in mindere mate van ICAM-1, op endotheelcellen konden verhogen. Het directe contact tussen mestcellen en endotheelcellen veroorzaakte een significante stijging van de expressie van deze leukocyt-adhesie moleculen. De inductie van ICAM-1, VCAM-1 en E-selectine was niet gerelateerd aan de mate van mestceldegranulatie, maar bleek veroorzaakt te worden door (een) stof(fen) anders dan histamine, die constitutief door mestcellen werd(en) vrijgesteld.

In Hoofdstuk 9 worden de resultaten zoals beschreven in dit proefschrift samengevat en in een breder kader geplaatst. 


\section{| publications}




\section{Full Papers:}

van Haaster, C.M.C.J., Engels, W., Lemmens, P.J.M.R., Hornstra, G. and Van der Vusse, G.J. Formation of prostanoids and hydroxy fatty acids by stimulated peritoneal mast cells: role of the dietary fat type in rat. (1993) Biochim. Biophys. Acta 1167:147-154.

van Haaster, C.M.C.J., Engels, W., Lemmens, P.J.M.R., Hornstra, G. and Van der Vusse, G.J. Rapid and highly sensitive high-performance liquid chromatographic method for the determination of histamine and 3-methyl histamine in biological samples using fluorescamine as the derivatizing agent. (1993) J. Chromatogr. 617:233-240.

van Haaster, C.M.C.J., Engels, W., Lemmens, P.J.M.R., Hornstra, G. and Van der Vusse, G.J. Rapid and highly sensitive high-performance liquid chromatographic method for the determination of histamine and 3-methyl histamine in biological samples using fluorescamine as the derivatizing agent: DISCUSSION (1994) J. Chromatogr. 657:261.

van Haaster, C.M.C.J., Engels, W., Lemmens, P.J.M.R., Hornstra, G., Van der Vusse, G.J. and Heemskerk, J.W.M. Differential release of histamine and prostaglandin $D_{2}$ by rat peritoneal mast cells: roles of cytosolic calcium and protein tyrosine kinases (1995) Biochim. Biophys. Acta 1265:79-88.

van Haaster, C.M.C.J., Engels, W., Duijvestijn, A.M., Lemmens, P.J.M.R., Hornstra, G. and Van der Vusse, G.J. Lack of evidence for a role of mast cell degranulation in acute hypoxia/reoxygenation-induced injury in the isolated rat heart (1996) J. Mol. Cell. Cardiol. (In Press)

van Haaster, C.M.C.J., Derhaag, J.G., Engels, W., Lemmens, P.J.M.R., Gijsen, A.P., Hornstra, G., Van der Vusse, G.J. and Duijvestijn, A.M. Mast cells and the induction of endothelial leukocyte-adhesion molecules in vitro. (Submitted for Publication)

\section{Abstracts:}

van Haaster, C.M.C.J., Engels, W., Lemmens, P.J.M.R., Hornstra, G. and Van der Vusse, G.J. Eicosanoid production in peritoneal mast cells: a model study for myocardial mast cells (1991) Abstracts $3^{\text {rd }}$ International Symposium on Lipid Metabolism in the Normoxic and Ischemic Heart: Rotterdam, September 9-10

van Haaster, C.M.C.J., Engels, W., Lemmens, P.J.M.R., Hornstra, G. and Van der Vusse, G.J. Eicosanoid production by stimulated peritoneal mast cells (1993) Am. J. Clin. Nutr. $57: 828 \mathrm{~S}$

van Haaster, C.M.C.J., Heemskerk, J.W.M., Engels, W., Lemmens, P.J.M.R., Hornstra, G. and Van der Vusse, G.J. Function of $\mathrm{Ca}^{2+}$ entry in histamine secretion and prostaglandin $D_{2}$ release in mast cells from rat (1993) Abstracts Academy Workshop on Cell Calcium: Amsterdam, November 15-17

van Haaster, C.M.C.J., Engels, W., Lemmens, P.J.M.R., Hornstra, G. and Van der Vusse, G.J. Mast cells are not involved in acute hypoxia/reoxygenation-induced injury in the isolated rat heart (1994) J. Mol. Cell. Cardiol. 26(6):55 
|CURRICULUM VITAE 
De auteur van dit proefschrift werd geboren op 13 juli 1967 te Maastricht. Na het behalen van het VWO-B diploma aan het Sint Maartenscollege te Maastricht in juni 1986, werd in hetzelfde jaar begonnen met de studie Gezondheidswetenschappen, afstudeerrichting Biologische Gezondheidkunde, aan de Rijksuniversiteit Limburg te Maastricht. Na de afstudeerstage via het Erasmus studenten-uitwisselingsprojekt aan het Klinisch Chemisch Laboratorium van het AZ Sint-Jan te Brugge (B) en een stage op de afdeling Algemene Biochemie van Janssen Pharmaceutica te Beerse (B), behaalde hij in maart 1991 het doctoraal examen. Van mei 1991 tot mei 1995 was hij werkzaam als Assistent In Opleiding aan het Instituut Hart- en Vaatziekten aan de Rijksuniversiteit Limburg te Maastricht, alwaar hij de werkzaamheden zoals beschreven in dit proefschrift uitvoerde. 
| DANKWOORD 
Zo, het zit er nu op! Dit proefschrift is tot stand gekomen dankzij de medewerking en het enthousiasme van veel mensen. Ik wil iedereen bedanken die hieraan, direct of indirect, een bijdrage heeft geleverd. Een aantal mensen wil ik graag met name noemen:

Allerierst, mien awwers en Daniëlle en René....... Zoewel tijdens mien studie es mien promotie-ónderzeuk höb geer altied geluusterd nao mien enthousiaste en soms minder enthousiaste verhaole. De wijze boe-op geer altied veur miech klaorstónt, en nog steeds stoon, waor en is veur miech onmisbaar.

Rob, Esther, Riet, Wim H., Bernadette, Marie-Louise, George, Bert, Appie en Han, Instituut Hart- en Vaatziekten, bedankt voor de prettige tijd die wij samen hebben gehad de afgelopen tijd. Vooral de 'dagjes uit' zal ik zeker missen.

Alle medewerkers van de Centrale Proefdiervoorzieningen, bedankt voor jullie hulp bij het voeren en verzorgen van de ratten.

Jo en Nicole, dankzij jullie heb ik de meeste weekenden 'ADV' gehad. Jo, jouw hulp bij het isoleren van de mestcellen was echt geweldig. Hoe weinig tijd jij soms ook had, jij maakte gewoon tijd om mij even te helpen. Dit vind je tegenwoordig niet vaak meer.

Frans Weekers, als ik weer eens ratten nodig had, zag ik jou soms denken: 'Wat mót van Haaster noe weer?'. Meestal is het jou gelukt om aan mijn vriendelijke, doch dringende verzoeken te voldoen. En trouwens, bij deze nog bedankt voor datgene wat ik van jou mocht (moest?) leren toen je nog 'miene meister' was!

Marianne, René en Peter $W$., jullie hebben voor mij de vetzuurbepalingen verricht. Zonder jullie hulp zou het allemaal niet zo vlot verlopen zijn. Bedankt daarvoor! René, de moeite die jij je hebt moeten doen om voor mij nog op tijd een aantal data te verzamelen, met name aan het eind van mijn onderzoek, heb ik enorm gewaardeerd. Jodil, 'mijn' eerste stagiair. Jodil, van de enorme hoeveelheid algemene ontwikkeling die jij hebt, heb ik veel geleerd. We hebben samen veel gelachen, vooral tijdens onze 'helium-experimenten'. Ik hoop dat ik je in de toekomst ook nog zal ontmoeten.

Glasblazer Janssen, de kwaliteit van uw glaswerk was zo goed, dat ik u de laatste twee jaren niet meer heb hoeven te bezoeken. De snelheid en vriendelijkheid waarmee u mij altijd bediende als tijdens de experimenten een onderdeel van mijn Langendorffopstelling stuk ging, kom je niet vaak meer tegen.

Adriaan, Josien en Annemie, in het laatste jaar van mijn onderzoek hebben jullie heel wat tijd moeten steken in het kweken van 'mijn' endotheelcellen en het scoren van de 'positieve cellen'. Zonder jullie hulp had ik het niet gered, en...., jullie weten waarom!

Renée, ondanks dat ik meestal onaangekondigd kwam vragen om 'wat endotheelcellen', vond jij toch meestal nog wel ergens een schaaltje met cellen die ik kon gebruiken. Zonder jouw hulp was het laatste hoofdstuk van mijn proefschrift niet geworden wat het nu is. Bedankt hiervoor en voor je interesse in mijn onderzoek.

Math en Marcha, toen ik bij jullie kwam met het idee om te vragen of een dubbelkleuring voor endotheelcellen en mestcellen in rattehartcoupes mogelijk was hebben jullie direkt hulp toegezegd. De foto's waren zo mooi dat ik er een van heb gebruikt als 'cover' van mijn proefschrift. Bedankt voor jullie spontane hulp! 
Wim Vleeming, onze toevallige ontmoeting op een congres in Rotterdam, helemaal aan het begin van mijn AIO-tijd, heeft ertoe geleid dat wij samen wat proefjes zijn gaan doen. Dat deze de basis zouden zijn voor Hoofdstuk 6 van mijn 'boekie', zoals jij dat zegt, kon ik toen nog niet vermoeden.

Gerrie, Chris en Michel, de mensen van de spoelkeuken. Jullie namen staan meestal niet in het dankwoord en daar horen ze echter wel thuis. Het mag ook wel eens gezegd worden dat jullie altijd bereid waren mij te helpen als ik 'even' iets snel gewassen moest hebben. Vooral jullie gezellige praatjes hebben mij laten zien dat er nog andere dingen zijn dan onderzoek doen. En Gerrie, een prettig weekend!

Pauline, Jolanda, Marion, Milou en Gerard, Bureau Internationale Betrekkingen. De praatjes tussen de middag in 'ons hok' waren altijd gezellig en die zal ik zeker missen.

Alle collega's van de afdeling Fysiologie, Humane Biologie en Immunologie. Ondanks het feit dat ik maar 'gast' was op jullie afdeling, voelde ik mij toch altijd welkom.

Wiel Debie en Gert Schaart, jullie spontane hulp en adviezen bij het maken van sommige foto's heb ik erg gewaardeerd. Bedankt daarvoor!

Johan, de tijd die jij hebt gestoken in het begeleiden van 'onze BBA-publicatie' is voor mij erg belangrijk geweest. Behalve inhoudelijke aspecten, heb ik van jou ook geleerd dingen zó op te schrijven dat er staat wat ik in gedachten eigenlijk bedoelde.

Uiteraard hoort hier ook een woord van dank ten aanzien van de leden van de beoordelingscommissie, Prof. dr. ir. W.H.M. Saris, Prof. dr. M. Borgers, Dr. J.W.H. Heemskerk, Prof. dr. A. van der Laarse en Prof. dr. R.S. Reneman.

Paul Borm, Edouard Bevers, Paul Comfurius, Eric van Breda en George Willems, bedankt voor juflie spontane bijdragen aan het proefschrift!

Rob (Koos) en Sylvia, mijn paranymfen. Bedankt natuurlijk voor jullie hulp bij mijn promotie, maar vooral voor jullie vriendschap de afgelopen jaren. Koos, het ga je goed! Paul, jouw assistentie in de ontelbare histamine-bepalingen heeft mij veel werk uit handen genomen. Behalve van jouw praktische kennis heb ik ook veel geleerd van de zaken die je uitvoerde als lid van de vakbond. En... ut beer heet gesmaak!

Wim, mijn begeleider en co-promotor. Als het nodig was, kon ik je midden in de nacht opbellen als ik een vraag had over het een of ander. lemand die zo vol overgave 'zijn' AIO begeleidt, zul je lang naar moeten zoeken. Behalve een begaafd behanger en 'Apple-deskundige', ben je iemand wiens persoonlijkheid ik zeer heb leren waarderen. Tenslotte, mijn promoteres, Prof. dr. G.J. Van der Vusse en Prof. dr. G. Hornstra: Ger, jouw kritische blik om mijn onderzoek heeft vaak zeer verhelderend gewerkt. De snelheid en kwaliteit waarmee jij manuscripten nakeek is, denk ik, door bijna niemand te evenaren. Het feit dat jij altijd tijd vrijmaakte als ik 'even' iets moet vragen of bespreken mag een voorbeeld zijn voor andere promotores.

Gerard, bedankt voor het vertrouwen dat je mij gegeven hebt om het onderzoek op mijn manier aan te pakken. Jouw immer nauwkeurige correcties van de diverse manuscripten en dit proefschrift zijn voor mij zeer waardevol geweest.

En naturelik, Bianca..... Zónder dien luusterend oer zow iech ut hiel gèt minder meekelik gehad höbbe! Mörrege is weer unne daag! 



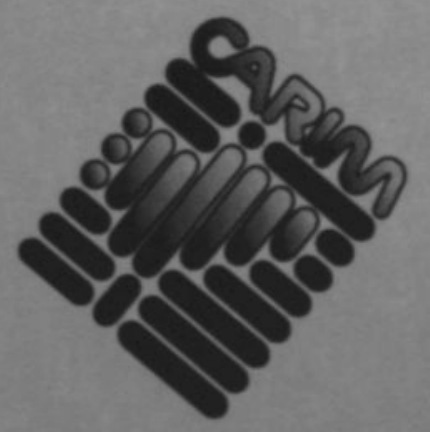

ISBN 9090091122 